\title{
Un sólo currículo: Pautas para un enfoque integrado hacia la educación en sexualidad, género, VIH y derechoshumanos
}

International Sexuality and HIV Curriculum Working Group

Nicole Haberland

Population Council

Deborah Rogow

Follow this and additional works at: https://knowledgecommons.popcouncil.org/departments_sbsr-pgy

Part of the Demography, Population, and Ecology Commons, Family, Life Course, and Society Commons, Gender and Sexuality Commons, International Public Health Commons, and the Medicine and Health Commons How does access to this work benefit you? Let us know!

\section{Recommended Citation}

International Sexuality and HIV Curriculum Working Group. 2011. "Un sólo currículo: Pautas para un enfoque integrado hacia la educación en sexualidad, género, VIH y derechoshumanos," edited by Nicole Haberland and Deborah Rogow. New York: Population Council. 


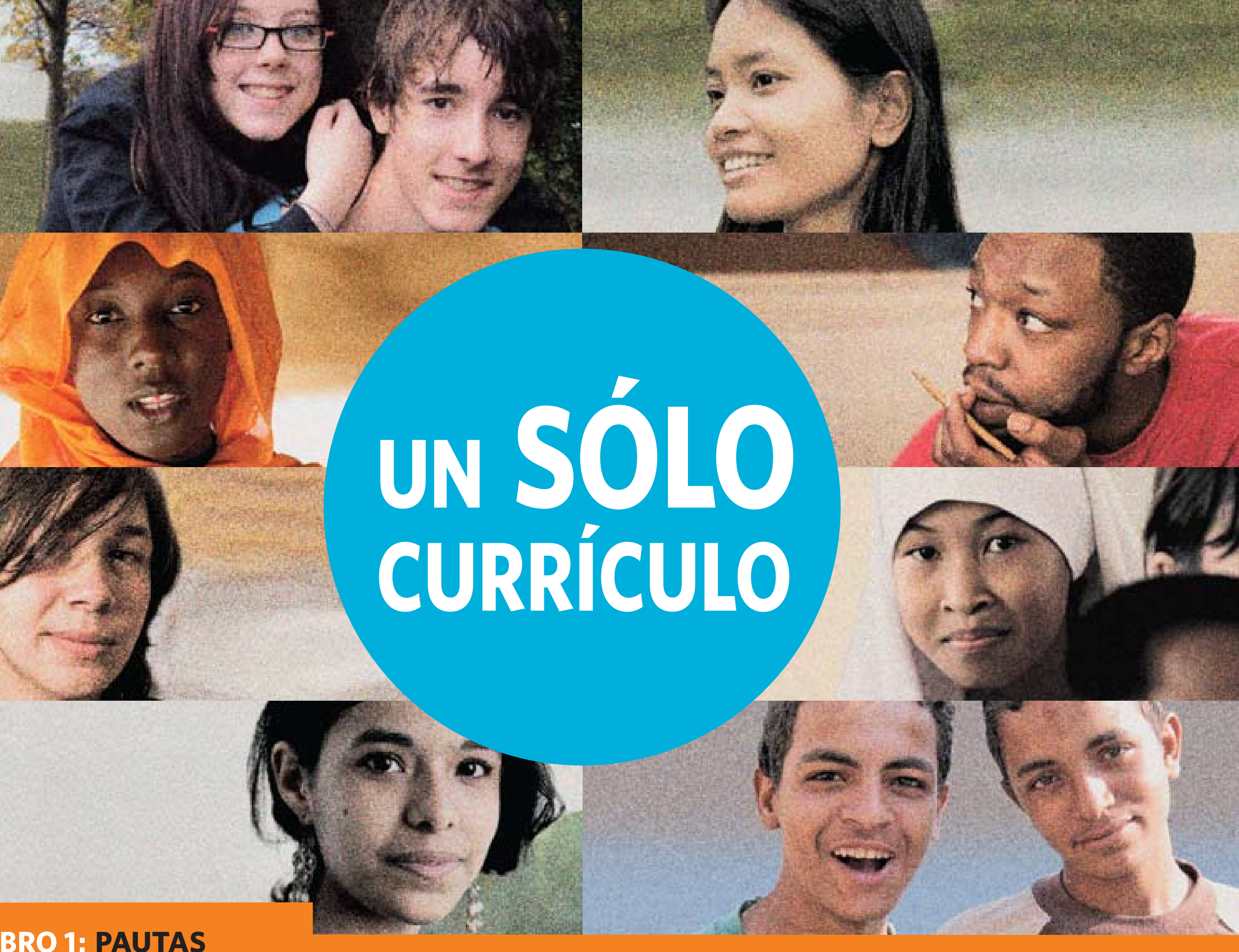

LIBRO 1: PAUTAS

PARA UN ENFOQUE INTEGRADO HACIA LA EDUCACIÓN EN SEXUALIDAD, GÉNERO, VIH Y DERECHOS HUMANOS 



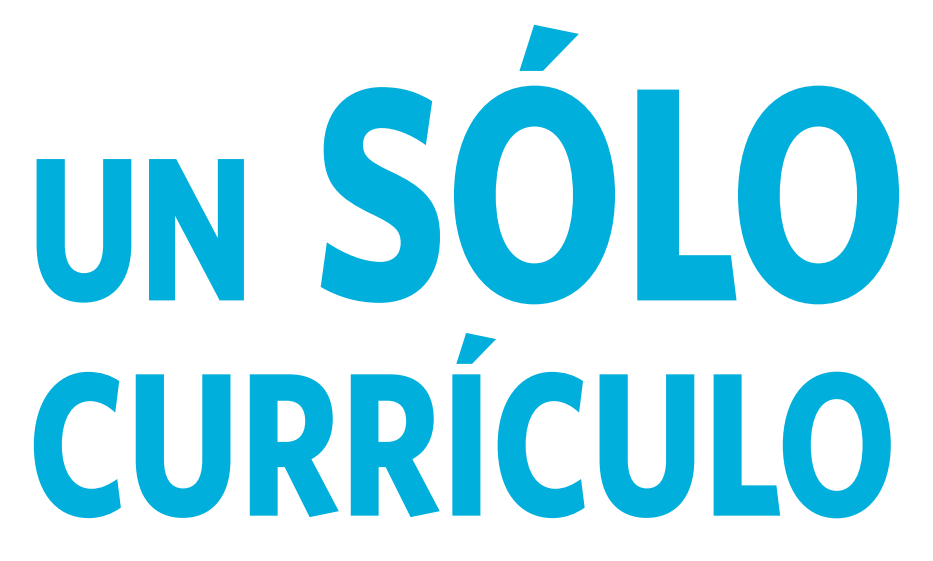

LIBRO 1: PAUTAS PARA UN ENFOQUE INTEGRADO HACIA LA EDUCACIÓN EN SEXUALIDAD, GÉNERO, VIH Y DERECHOS HUMANOS 


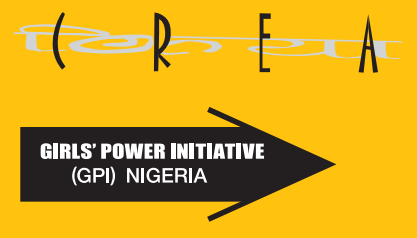

GIPPF $=$

GIPPF:

$\bigcirc$

INTERNATIONAL WOMEN'S

HEALTH COALITION

\section{Mexfam \\ Salud para tu familia}

1 Population Council
Un sólo currículo: Pautas y actividades para un enfoque integrado hacia la educación en sexualidad, género, VIH y derechos humanos fue desarrollado por un grupo de trabajo internacional compuesto por representantes de las siguientes organizaciones (en orden alfabético):

CREA (India): Caroline Earle, Sunita Kujur, Geeta Misra

Girls Power Initiative (Nigeria): Bene Madunagu, Grace Osakue

Federación Internacional de Planificación de la Familia (IPPF): Doortje Braeken

IPPF/Región del Hemisferio Occidental: Jessie Clyde, Denise Kohn

Coalición Internacional por la Salud de las Mujeres (IWHC): Kelly Castagnaro, Corinne Whitaker

Fundación Mexicana para la Planeación Familiar (Mexfam, México): Ofelia Aguilar

Population Council: Nicole Haberland, Deborah Rogow

El grupo de trabajo aportó una variedad de perspectivas y especialización técnica relevante en materia de sexualidad de adolescentes/educación en $\mathrm{VIH}$, incluidas las áreas de derechos y género, gerencia de programas, investigación y advocacy. Andrea Irvin también ayudó a redactar varias de las secciones. La traducción al español se llevó a cabo en coordinación con IPPF/WHR, bajo la supervisión de Marissa Billowitz.

\section{Escrito por el Grupo Internacional de Currículo en Sexualidad y VIH Editado por Nicole Haberland y Deborah Rogow}

Traducido al español por Xavier González

Coordinación del proyecto: Michelle Skaer, Jonah Stuart Brundage y Amy Handler

Diseño: Emanuela Frigerio, Hyun Auh, C\&G Partners, Nueva York

Producción: Mike Vosika, Christina Tse, Michelle Skaer, Edgar Peralta

Revisión de texto: Karen Tweedy-Holmes

Edición nivel de lectura: Gina Duclayan

Créditos fotográficos para imágenes de portada de sección: Introducción, Jacob Silberberg, cortesía de IPPF/WHR; unidad 1, Manoocher Ceghati, cortesía de IRIN; unidad 2, Michael Newman, cortesía de PhotoEdit; unidad 3, Gabe Cooney, cortesía de IPPF/WHR; unidad 4, Maura Carroll; unidad 5, Melissa May; unidad 6, Ronn Aldaman; unidad 7, Neil Thomas, cortesía de IRIN; unidad 8, Eugene Martin; hojas informativas, Helen Cole, cortesía de Photoshare. Todos los otros créditos fotográficos se identifican a un lado de la imagen.

Publicado por el Population Council, Nueva York.

Disponible para descarga sin costo en: www.unsolocurriculo.org

Copyright (c) 2011 The Population Council, Inc.

Cualquier parte de este volumen puede fotocopiarse sin permiso de las autoras o editoras, siempre y cuando se de crédito a la publicación y las copias se distribuyan gratuitamente. Cualquier reproducción comercial requiere permiso por escrito previo del Population Council. Por favor también asegúrese de dar crédito a cualquier fuente original, como se indica para las actividades seleccionadas.

ISBN: Pautas: 978-0-87834-120-7; Actividades: 978-0-87834-121-4; Set: 978-0-87834-122-1 
En memoria de Enofe Duncan Osakue 
INVESTIGADORES han identificado la desigualdad de género como un factor clave que fomenta la pandemia del SIDA.

ENCARGADOS DE FORMULAR LAS POLITICAS han pedido que la educación sexual y la prevención del VIH tengan énfasis en la igualdad de género y derechos humanos.

EDUCADORES quieren enseñar a la gente joven las habilidades de pensamiento crítico necesarias para construir sociedades justas y solidarias. 


\section{UN SÓLO CURRÍCULO}

responde a estas necesidades. 


\section{agradecimientos}

Un sólo currículo: Pautas y actividades para un enfoque unificado hacia la educación en sexualidad, género, VIH $y$ derechos humanos es el producto de contribuciones de personas de todo el mundo. Nuestro sincero agradecimiento a cada una de las personas que contribuyeron a este esfuerzo.

Wendy Baldwin, Carmen Barroso, Kate Bourne, Judith Bruce, Vicente Díaz, Beth Fredrick, Adrienne Germain, Naana Otoo-Oyortey, Tim Shand y Victoria Ward proporcionaron orientación y asesoramiento invaluables. Maggie Díaz y Juan Díaz de Reprolatina revisaron el volumen de PAUTAS para verificar su precisión técnica y clínica. Evan Read creó las ilustraciones originales y Jared Stamm desarrolló el sitio web. Nell Timreck y Ernestine Heldring contribuyeron sustancialmente durante las revisiones finales. Estamos en deuda especialmente con Mike Vosika y Karen Tweedy-Holmes por su

extraordinario apoyo a lo largo del proceso de producción. Gracias también a los numerosos amigos y colegas que compartieron generosamente sus imágenes fotográficas con nosotros.

Michelle Skaer y posteriormente, Jonah Stuart Brundage, coordinaron este proyecto con gran inteligencia e igual ánimo; sus contribuciones fueron fundamentales en cada etapa. Más de 50 personas expertas revisaron el manuscrito durante su desarrollo; y ocho organizaciones apoyaron en las pruebas de campo de las actividades originales de muestra. Estas personas y organizaciones aparecen en una lista en la página siguiente (las afiliaciones institucionales se indican solamente para propósitos de identificación y se refieren a la afiliación vigente en el momento de la revisión). Estamos profundamente agradecidos por su apoyo técnico, tiempo y percepciones; sin su participación, este documento no sería lo que es. Las editoras son responsables exclusivas de errores u omisiones.

IPPF/WHR coordinó la traducción al español, y Marissa Billowitz de IPPF/WHR la revisó con Angela Sebastiani, consultora.

Finalmente, agradecemos a nuestros donantes, cuyo apoyo financiero y colegiado hizo posible Un sólo currículo. Nuestro sincero agradecimiento a la Fundación Ford, la fundación William y Flora Hewlett, la Fundación Libra, la Fundación John D. y Catherine T. MacArthur, el Departamento del Reino Unido para el Desarrollo Internacional y el Fondo de Población de las Naciones Unidas (UNFPA). El proyecto se benefició también enormemente del apoyo financiero proporcionado por la Federación Internacional de Planificación de la Familia (IPPF), IPPF/Región del Hemisferio Occidental, la Coalición Internacional por la Salud de las Mujeres (IWHC) y el Population Council. 
GRUPO ASESOR Y REVISOR

Aziza Ahmed (Comunidad Internacional de Mujeres Viviendo con VIH/SIDA)

Lucy Atkin (Colibri Consulting and Hesperian)

Doris Bartel (CARE)

Marina Bernal (MULABI)

Jennifer Catino (EngenderHealth)

Esther Corona (Asociación Mexicana de Educación Sexual y WAS)

Sarah Hawker Costa (Fondo Global para Mujeres)

Jane Cottingham (OMS)

Karen Fazekas (Family Health International)

Gill Gordon (Alianza Internacional contra el VIH/SIDA)

Nik Hartley (Students Partnership Worldwide)

Christine Heritier (Afghanistan Libre)

Rachel Jacobson (Coalición Global de Jóvenes contra el VIH/SIDA)

Magaly Marques (Planned Parenthood of Los Angeles)

Rafael Mazin (OPS)

Alexander McKay (SIECCAN)

Prabha Nagaraja (TARSHI)

Rick Olson (UNICEF)

Christine Ricardo (Instituto Promundo)

Saira Shameem (Asian Pacific Resource and Research Centre for

Women - ARROW)

Robert Thomson (UNFPA)

Nell Timreck (Students Partnership Worldwide)

EQUIPO DE CAMPO PARA PRUEBA DE ACTIVIDADES

Aahung (Pakistan)

Asociación Demográfica Costarricense (Costa Rica)

Association for Sexual and Reproductive Health XY (Bosnia)

Belize Family Life Association (Belice)

Fundación Mexicana para la Planeación Familiar (MEXFAM)

(México)

Girls Power Initiative (Nigeria)

Lesotho Planned Parenthood Association (Lesotho)

Reprolatina (Brasil)

\section{CONSEJO TÉCNICO}

Anónimo (participación individual)

Gautam Bhan (participación individual)

Yvonne Bogaarts (World Population Foundation)

Jeff Buchanan (participación individual)

Margarita Díaz (Reprolatina)

Uyi - Oni Ekhosuehi (Optimal Health and Development Project)

Nadine Dimodi Ekotto (ALVF)

Chris Fung (USAID)

Tamara Gonçalves (CLADEM/Miembro de Brasil)

Angela Heimburger (Human Rights Watch)

Ernestine Heldring (Scenarios USA)

Patty Herrera (Latino Community Solutions)

Laura Katzive (Centro para los Derechos Reproductivos)

Scott Kellerman (Population Council)

Martha Kempner (SIECUS)

Tang Kun (China Family Planning Association)

Katarina Lindahl (RFSU)

Eugenia López Uribe (Balance Promoción para el Desarrollo y

Juventud)

Veronica Magar (CARE)

Lori Michau (Raising Voices)

Carmen Murguia (UNFPA)

Ratidzai Ndlovu (UNFPA)

Karen Newman (participación individual) ${ }^{\star}$

Suzyo Nthazie (Young African Advocates for Rights)

Sabina Rashid (BRAC University)

Nell Rasmussen (Danish National Board of Social Services)

Sundari Ravindran (Achutha Menon Centre for Health Science

Studies)

Meredith Sheehy (Population Council)

Joann Stemmermann (participación individual)

John Townsend (Population Council)

Lita Townsend (Cleveland Metropolitan Schools)

Wijit Wong (World Population Foundation)

Margot Zimmerman (participación individual)

^Proporcionaron los insumos técnicos iniciales. 


\section{índice}

INTRODUCCIÓN

LA SALUD SEXUAL Y EL BIENESTAR REQUIEREN DE LOS DERECHOS HUMANOS

cómo nos tratamos unos a otros: valores y sociedad

¿qué son los "derechos humanos"?

derechos sexuales y derechos reproductivos

promoción de los derechos humanos, incluidos los derechos sexuales y los derechos

reproductivos

glosario (conceptos básicos sobre derechos humanos)

\section{GÉNERO}

definición de género

identidad de género

las normas y roles de género se consolidan durante la infancia y la adolescencia

género y educación

estereotipos de género en los medios

cómo afecta el género la movilidad, la conexión social y los espacios públicos seguros

cómo afecta el género la participación cívica y política

género, trabajo y recursos económicos: dentro y fuera de casa

género y matrimonio

género y religión

género y autonomía corporal

género y violencia

la coerción sexual es una forma de violencia basada en el género

respuesta a la violencia basada en el género

las normas y los roles de género cambian con el tiempo

género: nuestras propias decisiones y acciones

cambiar el mundo que nos rodea

glosario (conceptos básicos sobre género) 
acerca de la sexualidad

derechos sexuales

sexualidad y sociedad

las normas sexuales varían según el género: el "doble estándar" para el comportamiento sexual

deseo sexual

diversidad sexual

anatomía y placer sexual

expresión y gozo sexual

comportamiento sexual

motivaciones para tener o no tener relaciones sexuales

consentimiento sexual y coerción

creación de relaciones mutuamente respetuosas además de responsables

preocupaciones sobre la función sexual

advocacy para el bienestar sexual

glosario (conceptos básicos sobre sexualidad)

\section{RELACIONES INTERPERSONALES}

introducción a las relaciones interpersonales

relaciones en nuestras vidas

¿cómo puede nuestra relación ser más respetuosa y satisfactoria?

relaciones románticas: cortejo y citas

romance: ¿qué es enamorarse? ¿qué es "amor verdadero"? ¿qué hay de los celos?

actividad sexual en las relaciones

relaciones íntimas a largo plazo

dificultades en las relaciones

término de una relación

las normas sobre las relaciones están cambiando

HABILIDADES DE COMUNICACIÓN Y TOMA DE DECISIONES

factores que afectan la comunicación

sugerencias para una comunicación efectiva

estilos de comunicación directos versus indirectos

conversación con su pareja sobre temas de sexo y salud sexual

toma de decisiones

nuestras decisiones como base de acción 
imagen corporal

pubertad

conocimiento de nuestro cuerpo

órganos sexuales y reproductivos

fecundidad y reproducción (¿de dónde vienen los bebés?)

cuando el embarazo continúa

aprendizaje sobre el propio cuerpo: un movimiento global

\section{SALUD SEXUAL Y REPRODUCTIVA}

el derecho a los servicios de salud

PARTE 1: INFECCIONES DE TRANSMISIÓN SEXUAL, INCLUIDOS EL VIH Y EL SIDA

acerca de las infecciones de transmisión sexual (ITS), VIH y SIDA

métodos de protección contra las ITS y el VIH

por qué la gente no usa protección y por qué la igualdad de género es clave

en la lucha contra el SIDA

personas que viven con $\mathrm{VIH}$ y SIDA

derechos y responsabilidades relacionados con la prevención de las ITS y el VIH

infecciones del tracto reproductivo (ITR)

PARTE 2: DECISIONES SOBRE LA PROPIA FECUNDIDAD: ANTICONCEPCIÓN Y ABORTO

sobre la anticoncepción

diferentes métodos anticonceptivos

embarazo no planeado y aborto

ADVOCACY PARA LA SALUD SEXUAL, DERECHOS E IGUALDAD DE GÉNERO

reflexionar sobre nuestras propias actitudes

reconocer si algo es justo o injusto

cambiar el mundo que nos rodea

obstáculos enfrentados en el trabajo de advocacy para el cambio social

el significado y poder de la advocacy en la vida de las personas

acción efectiva; módulo de aprendizaje basado en proyectos 
INRODUCCIÓN (1) 


\section{Un sólo currículo: ¿qué es?}

\section{Esto es un recurso práctico para el desarrollo curricular, particularmente en las áreas de género, sexualidad y VIH.}

Un sólo currículo ofrece contenido sobre casi cualquier tema que usted quiera incluir en enseñando jóvenes sobre género,salud sexual, VIH, sexualidad, relaciones, comunicación, violencia entre una pareja íntima, pubertad, reproducción, anticoncepción, aborto, o defensa de sus propios derechos. Es intencionalmente completa, para que usted pueda seleccionar el contenido y las actividades que satisfacen sus necesidades.

Sin embargo, Un sólo currículo no es solamente comprensivo. Si no, toma un enfoque integrado a estos temas. La investigación muestra que el contexto social de los jóvenes, factores individuos, y los resultados de salud son profundamente interconectadas. Por lo tanto, este recurso se ayudará a pensar y enseñar acerca de una serie de temas relacionados — como un sólo currículo.

Es importante que Un sólo currículo también incluya un enfoque crítico al proceso de aprendizaje - de tal modo, reforzando la educación en general. Además, esto ayuda a los países para responder a los Objetivos de Desarrollo del Milenio. En todas estos formas, trae un enfoque nuevo y práctico para educar los jóvenes en un mundo diverso y rápidamente cambiante.

Un sólo currículo tiene siete características fundamentales, que se describen en la página opuesta. Estas características se basan en las estrategias y prioridades establecidas por varias agencias mundiales que trabajan en el campo de la salud y la educación, incluida la Asamblea General de las Naciones Unidas, ${ }^{1}$ UNAIDS, ${ }^{2}$ la Organización de la Salud Mundial, ${ }^{3}$ UNESCO, ${ }^{4}$ y la Asociación Mundial para la Salud Sexual. ${ }^{5}$ Un sólo currículo fue desarrollado por un grupo internacional de expertos para asegurar que su perspectiva fuera relevante para educar a gente joven a nivel mundial — desde África hasta el Pacifico, desde Asia hasta las Américas, desde Europa hasta el mundo Árabe.

El fin último de Un sólo currículo es desarrollar la capacidad de los jóvenes para que puedan gozar - y defender sus derechos a - la dignidad, la igualdad, y vidas sexuales responsables, agradables y saludables. 


\section{SIETE CARACTERÍSTICAS CLAVES DE Un sólo currículo}

1 Basado en evidencia, esto es, se fundamenta en las lecciones aprendidas de currículos evaluados por investigadores a nivel mundial, ${ }^{6}$ a la vez que incorporan hallazgos importantes sobre los vínculos entre la dinámica de género y los resultados en materia de salud sexual;

2 Integral, incluye información precisa sobre todos los temas psicosociales y de salud necesarios para conformar un currículo integral que cubra la sexualidad, la prevención del VIH, el derecho a abstenerse de tener relaciones sexuales y la educación en vida familiar; ${ }^{7}$

3 Basado en valores centrales y en los derechos humanos, esto es, promueve los principios de equidad, dignidad humana, trato igual, oportunidades de participación y derechos humanos para todas las personas como base para alcanzar la salud sexual, la salud reproductiva y el bienestar en general; ${ }^{8}$

4 Sensible al género, poniendo énfasis en la importancia de la igualdad de género ${ }^{9}$ y el ambiente social en general para lograr la salud sexual y reproductiva, así como el bienestar general para niños y niñas;

5 Promueve el crecimiento académico y el pensamiento crítico, a través del fomento de hábitos de pensamiento necesarios para comprender las relaciones con uno mismo, con otras personas y con la sociedad, así como la forma en que estas relaciones afectan profundamente nuestras vidas. Así, proporciona una base para extender la educación en sexualidad y la prevención del VIH a las clases de civismo, estudios sociales y lenguaje-artes entre otras materias;

6 Fomento de la participación cívica, mediante la defensa de la idea de que cada persona es importante y que puede hacer una diferencia positiva en el mundo que le rodea. Ayuda a fortalecer las habilidades de advocacy que son cruciales para crear una sociedad más justa y solidaria; y

7 Culturalmente apropiado, al reflejar las diversas circunstancias y realidades de la gente joven en todo el mundo.

\section{UN CURRÍCULO, METAS MÚLTIPLES}

AUMENTAR EN LA GENTE

\section{JOVEN}

Su capacidad de tomar decisiones responsables y actuar conforme a sus propias decisiones

Su capacidad de participar en la sociedad y ejercer sus derechos humanos

Su pensamiento crítico, y sus logros educativos en general

Sentido de auto-eficacia y autonomía

Sentido de bienestar sexual y placer

\section{REDUCIR LAS TASAS EN}

ADOLESCENTES DE

\section{Embarazos no planeados}

Infecciones de transmisión sexual, incluido el VIH

Relaciones sexuales no deseadas bajo coerción

Violencia basada en género 


\section{Un sólo currículo: ¿por qué se necesita?}

\section{HECHO}

La gente joven que ha desarrollado normas de género igualitarias tiene mejores resultados en materia de salud sexual que sus pares.

\section{HECHO}

\section{Los acuerdos}

internacionales exigen una educación en sexualidad e igualdad de género.

"... sabemos lo que representa cambiar de fondo la situación de esta epidemia [del SIDA]. . . Requiere un cambio real y positivo que otorgue más poder y confianza a las mujeres y las niñas; y que transforme las relaciones entre las mujeres y los hombres, a todos los niveles de la sociedad."

- Ex Secretario General de las Naciones Unidas, Kofi Annan
La comunidad mundial ha asignado prioridad a la lucha contra el SIDA. La mayoría de los gobiernos también han firmado acuerdos internacionales que los comprometen a cumplir con los principios de igualdad de género y derechos humanos. Pero ¿cómo se vinculan estos principios? ¿Por qué la igualdad de género y los derechos humanos son cruciales para alcanzar la salud y el bienestar?

El hecho es que las normas de género afectan profundamente la capacidad de la gente joven para tomar e implementar decisiones relacionadas con sus propias vidas sexuales. Por ejemplo, la imperdonable realidad es que las relaciones sexuales, el matrimonio y el embarazo no son ni voluntarios ni se basan en decisiones informadas para decenas de millones de niñas. Los hombres jóvenes también experimentan fuertes presiones para estar a la altura de expectativas poco realistas de masculinidad, lo que termina afectando de manera negativa su salud.

Las consecuencias de esto son reales. Estudios realizados en países tanto en desarrollo como desarrollados, confirman que la gente joven que cree en la igualdad de género tiene mejores resultados en materia de salud sexual que sus pares. En contraste, la gente joven que mantiene actitudes menos igualitarias, tiende a tener peores resultados en esta materia. Por ejemplo, la gente joven que cree que los hombres deben ser "duros" y que deben tener más poder que las mujeres, tienen menor probabilidad de usar condones o anticonceptivos y mayor probabilidad de tener múltiples parejas sexuales. Ellos también tienen mayor probabilidad de participar en relaciones íntimas que involucran violencia. Las mujeres que tienen relaciones con un alto nivel de control masculino, también tienen mayor probabilidad de reportar VIH y embarazos no planeados. De manera similar, hay estudios que reflejan esta constelación de desigualdades de género y mala salud sexual, al demostrar que la violencia de pareja íntima está asociada con tasas más altas de embarazos no planeados, ITS y VIH. ${ }^{10}$ Estos hallazgos dejan en claro que la gente joven necesita oportunidades para aprender sobre la igualdad de género y los derechos humanos; especialmente, debido a que estos temas afectan sus vidas sexuales y, de hecho, su felicidad.

Desafortunadamente, los programas de educación sexual se han quedado atrás en la aplicación de estos hallazgos. Pocos currículos sobre educación sexual abordan los temas de género y derechos de una manera relevante. Esta deficiencia es particularmente preocupante, debido a que pocos currículos sobre temas de sexualidad o del VIH han demostrado tener un impacto estadísticamente significativo ya sea en la prevención de los embarazos no planeados o de las infecciones de transmisión sexual. ${ }^{11}$ 
La lección - misma que ignoramos a riesgo de las y los adolescentes — es que la igualdad de género y los derechos humanos no son solamente nobles ideales. Más bien, son elementos claves para evitar la propagación del VIH y para posibilitar que la gente joven crezca para gozar de buena salud, así como de vidas sexuales responsables y satisfactorias. De hecho, es en respuesta a tales hallazgos de las investigaciones y también como un asunto de dignidad humana, que la comunidad global - gobiernos, sociedad civil y las agencias internacionales — está pidiendo de manera creciente una educación en sexualidad y en prevención del VIH que aborden los temas de género y derechos humanos. Las y los educadores hoy en día necesitan recursos para presentar estos conceptos de formas que sean significativas y efectivas.

Felizmente, hay nuevos programas educativos en sexualidad y prevención del VIH en todo el mundo que son innovadores y que están prestando una mayor atención a la igualdad de género y los derechos humanos. Lo que resulta más atractivo es que tales enfoques están ahora demostrando tener resultados que son prometedores; ${ }^{12}$ es hora de implementar y probar tales enfoques de manera más extensa.

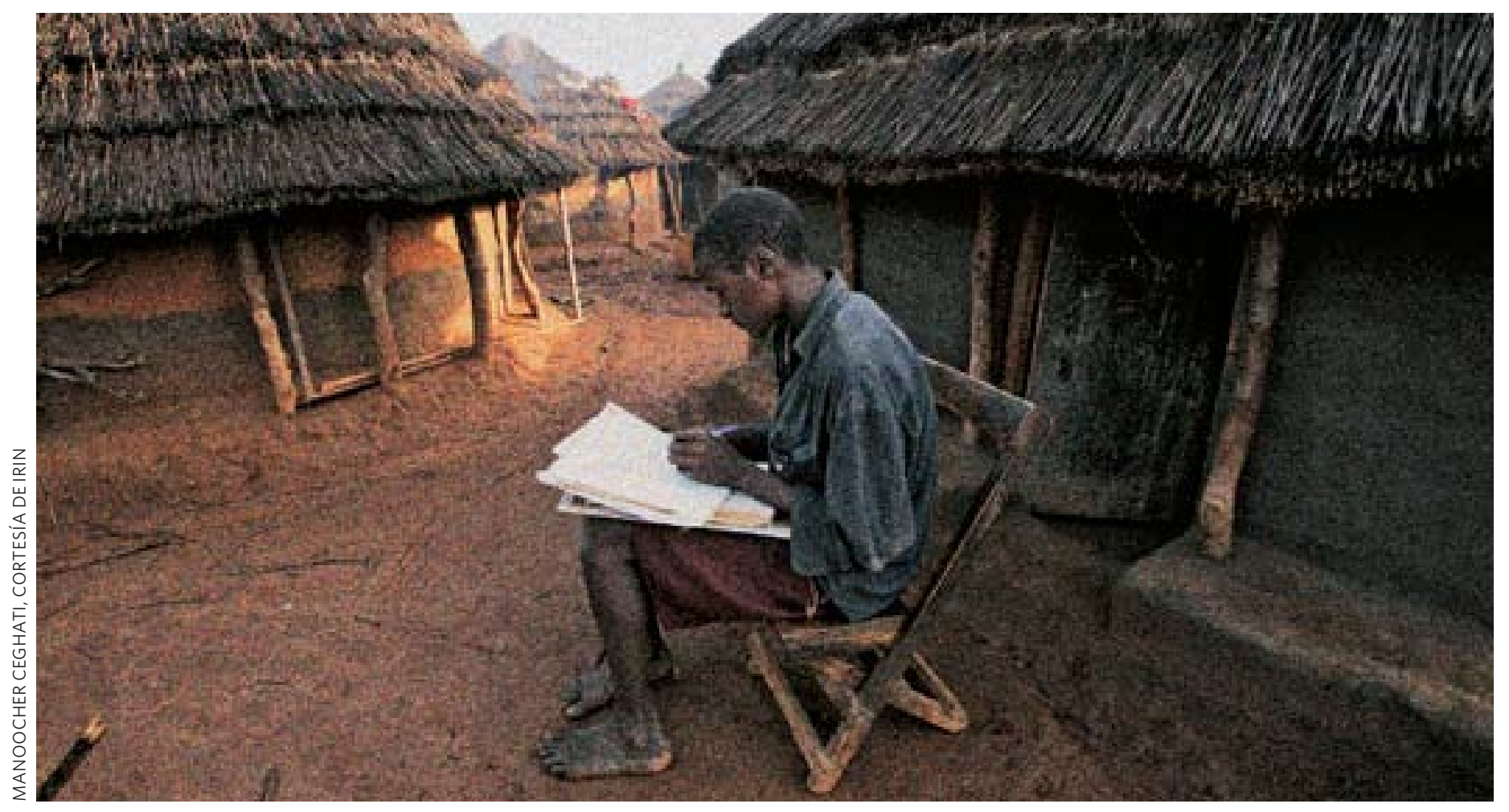




\section{Un sólo currículo: ¿quién puede usarlo?}

Un sólo currículo está diseñado primordialmente para quienes desarrollan planes de estudio, las y los maestros de escuela y educadores comunitarios que son responsables de la educación en las áreas de sexualidad/salud sexual (incluido el SIDA), el civismo y los estudios sociales. Las y los usuarios pueden aprovechar las pautas y actividades incluidas en este kit, para cubrir sus necesidades; por ejemplo:

- para desarrollar o modificar currículos exhaustivos (de cualquier duración) apropiados para su entorno;

- para diseñar unidades de enseñanza enfocadas de manera más específica (por ejemplo, sobre género o salud sexual); y

- para usarlas como recurso en planes de lecciones de un sólo tema (por ejemplo, género y los medios, toma de decisiones sobre relaciones sexuales, protección de uno mismo y de la pareja contra el VIH, reflexiones sobre masculinidad).

Una segunda audiencia para el kit Un sólo currículo incluye a quienes formulan las políticas de salud y educación, así como administradores de centros educativos.

Este kit puede ayudar a estos profesionales a que sus iniciativas de educación sobre sexualidad y VIH respondan a las necesidades de aprendizaje de la gente joven y a las declaraciones de política de organismos como la Asamblea General de las Naciones Unidas (Objetivos de Desarrollo del Milenio ${ }^{13}$ ), ONUSIDA, UNESCO, la Organización Mundial de la Salud y otras agencias. ${ }^{14}$ Además, los métodos que son el núcleo de Un sólo currículo apoyan el fortalecimiento de habilidades de pensamiento de orden superior (como la investigación, la reflexión y el análisis) y fomentan la conexión de las y los estudiantes con la escuela. De esta forma, las escuelas pueden usar la educación sexual y la prevención del VIH para fortalecer la educación en general, en vez de competir con otras metas académicas igualmente valiosas.

En todo el mundo, la educación en sexualidad tiene lugar en una gran variedad de contextos culturales y políticos. Un sólo currículo: Pautas y actividades está diseñado para presentar información sensible de manera apropiada en un amplio rango de contextos en África, las Américas, el Mundo Árabe, Asia, Europa y el Pacífico. El material incluye muchos ejemplos provenientes de diferentes entornos culturales. La siguiente sección (Un sólo currículo: dónde y cómo usarlo) ofrece orientación para las y los educadores y para quienes formulan políticas sobre cómo adaptar fácilmente estos materiales a sus entornos particulares. 


\section{Un sólo currículo: dónde y cómo usarlo}

\section{EN RESPUESTA A LAS PETICIONES DE LAS Y LOS EDUCADORES}

Un sólo currículo proporciona los fundamentos para un plan de estudios que puede ofrecerse en diferentes entornos. Puede usarse para diseñar un currículo que será aplicado en escuelas, en temas que van desde la salud y biología hasta los estudios sociales y literatura. También es útil para sesiones de enseñanza fuera del horario escolar regular o programas educativos en entornos comunitarios. Estas situaciones podrían incluir servicios de salud, programas de jóvenes y otras formas de educación informal. También, puede adaptarse a currículos de educación para adultos.

Los programas educativos sobre sexualidad y VIH varían significativamente en términos del énfasis sustantivo y duración. Por lo consiguiente Un sólo currículo es altamente flexible y está diseñado para permitir que las y los usuarios de este material identifiquen rápidamente la información y nivel de detalle que necesitan. Por ejemplo, el contenido está dividido en ocho unidades, cada una de ellas con subtemas. Dentro de cada subtema hay una serie de enunciados claves; y muchos de estos enunciados se complementan con un mayor detalle o con ejemplos completos derivados de varios entornos culturales. De esta forma, las y los usuarios del kit pueden seleccionar con facilidad cuáles unidades, cuáles subtemas y qué nivel de detalle satisface mejor sus necesidades. El currículo más completo se derivará del total de ocho unidades. Sin embargo, quienes tengan un tiempo limitado para desarrollar un currículo o para enseñar estos temas, pueden referirse al margen color oro situado en el extremo derecho, para una muestra recomendada de contenidos y actividades selectos.

El contenido de Un sólo currículo fue desarrollado para usar con gente joven en edades de 15 años o más, tanto dentro como fuera del sistema escolar. Cada vez más, sin embargo, personas expertas y quienes formulan políticas ven la necesidad de comenzar con este tipo de educación a edades más tempranas. La pubertad y la adolescencia temprana marcan un momento en el que las actitudes y comportamientos relacionados con el género se vuelven más distintivos y quedan establecidos; y cuando una gran proporción de niñas adolescentes pueden todavía ser atendidas a través del sistema de educación formal. Muchos educadores que enseñan a menores de 15 años, pueden aprovechar esta etapa para crear un currículo apropiado. Debe tenerse cuidado, desde luego, para considerar los requerimientos educativos especiales de una audiencia más joven. [Para consultar una lista de las actividades que se adaptan más fácil y apropiadamente para las y los estudiantes más jóvenes, vea las páginas introductorias del volumen de ACTIVIDADES. $]^{15}$

Finalmente, Un sólo currículo: Pautas y actividades está diseñado de manera flexible para ser utilizado en muchas culturas. Aplica los principios universales para las variadas circunstancias culturales y sociales en las que vive la gente. Naturalmente, las y los educadores pueden querer poner énfasis en ciertas secciones con respecto a otras debido a razones culturales y políticas, o por las necesidades particulares de grupos especiales. Una revisión realizada a nivel mundial sugiere que Un sólo currículo es útil para orientar el diseño de planes educativos para una amplia gama de poblaciones.
Proporcionamos una muestra de actividades recomendadas para quienes tienen menos de 14 horas disponibles para enseñanza, pero que aún así desean aprovechar todas las unidades:

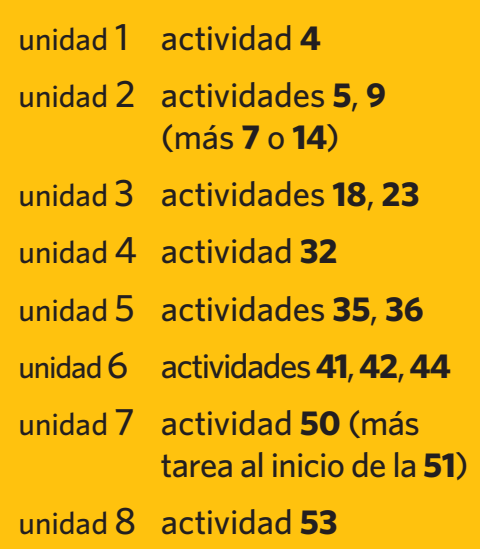




\section{Un sólo currículo: ¿cuál es su contenido?}

Este kit, compuesto por dos libros, proporciona los elementos esenciales para desarrollar un currículo basado en derechos, sensible al género y con un enfoque participativo, para la educación en sexualidad y VIH.

\section{Libro 1: PAUTAS}

Una introducción que incluye un argumento de política basada en la evidencia

Siete unidades de contenido (cada una con Objetivos de Aprendizaje, Contenido Clave y Puntos para Reflexión)

Una unidad final basada en proyectos (para apoyar el trabajo de advocacy y aplicar las lecciones aprendidas)

\section{2 hojas informativas}

\section{Libro 2: ACTIV/DADES}

Métodos efectivos de enseñanza

\section{4 actividades}

Recursos o materiales adicionales

Cada uno de estos libros se describe brevemente en las páginas siguientes. 


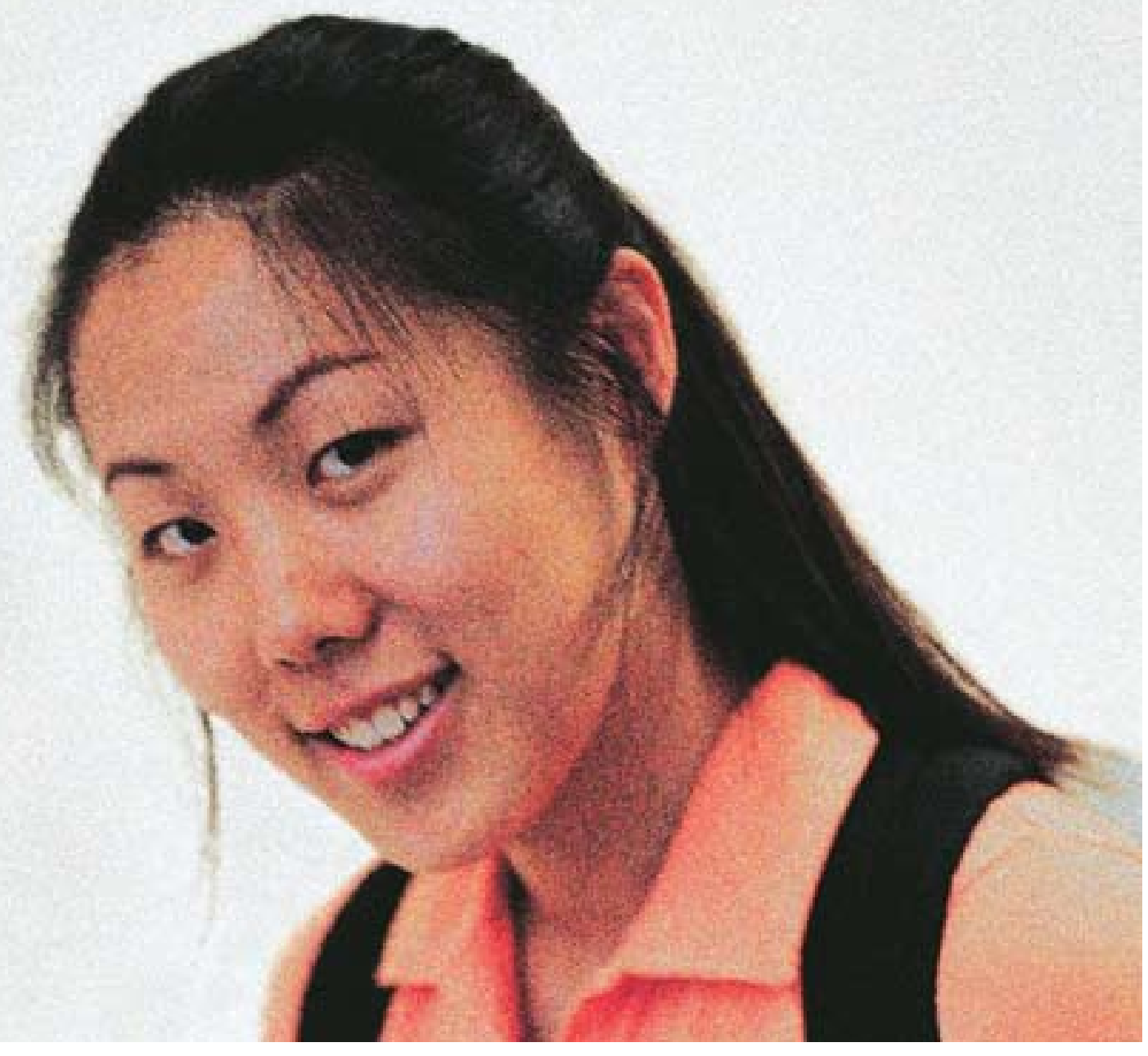

9 


\section{libro de pautas}

UNIDADES DE CONTENIDO: Las primeras siete unidades del libro de PAUTAS proporcionan la información necesaria para un currículo exhaustivo que integra los temas de género, derechos humanos, sexualidad, salud sexual y VIH. Usted verá también unos "Puntos de Reflexión" especiales en los márgenes color oro. Estos Puntos de Reflexión ilustran formas de usar el material para estimular las habilidades de pensamiento crítico de las y los estudiantes. Estas preguntas pueden también ayudar a las y los educadores a pensar sobre el contenido en formas creativas. Usted también verá recuadros naranja que vinculan el contenido seleccionado con las actividades innovadoras para el salón de clase (que se encuentran en el libro de ACTIVIDADES que acompaña el kit). Finalmente, la Unidad 8 proporciona los antecedentes y pautas para el aprendizaje basado en proyectos en el área de advocacy y cambio social.

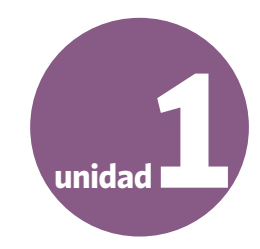

\section{LA SALUD SEXUAL Y EL BIENESTAR REQUIEREN DE LOS DERECHOS HUMANOS}

¿Por qué la educación en sexualidad y prevención del VIH debe incluir contenido sobre los derechos humanos? Esta unidad explica cómo la salud sexual y el bienestar emocional están conectados con la capacidad de la persona de ejercer sus derechos humanos (por ejemplo, su derecho a la educación y libertad de expresión). Estos derechos se extienden a la protección del propio cuerpo, la sexualidad y la salud. Esta unidad pone énfasis en la importancia de poder ejercer los propios derechos con confianza. Describe acciones que la gente joven puede tomar para promover el respeto. Muestra cómo pueden proteger la salud y los derechos sexuales y reproductivos de ellos mismos y de sus parejas.

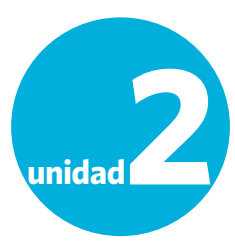

\section{GÉNERO}

Lograr la igualdad de género es un imperativo ético y un Objetivo de Desarrollo del Milenio de crucial importancia. Esta unidad permite a las y los educadores que aborden los temas de género de manera efectiva, proporcionando apoyo a jóvenes de ambos sexos. Ofrece información sobre la forma en que las normas de género funcionan en la sociedad — en las relaciones familiares, en la escuela, en la forma en que las personas experimentan la violencia, en los medios y en otras partes. Esta unidad también explica cómo los roles de género afectan la sexualidad y la salud sexual. Ayuda a niños y niñas a pensar de manera crítica y a reflexionar sobre sus propias actitudes respecto al género, de una manera que sea realmente significativa.

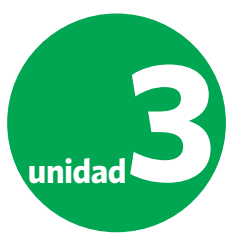

\section{SEXUALIDAD}

Aunque esta unidad incluye información biológica básica sobre sexualidad, también pone énfasis en los fundamentos sociales de la sexualidad en las vidas de las personas y en las comunidades. El contenido examina la forma en que las normas culturales y de género afectan la manera como se vive la sexualidad (emociones, sentimientos, actitudes y prácticas), incluyendo la vivencia y expresión del placer. También revisa algunas de las inquietudes más comunes que la gente experimenta con respecto a sus vidas sexuales, incluido el sentir presión para tener relaciones sexuales no deseadas o inseguras.

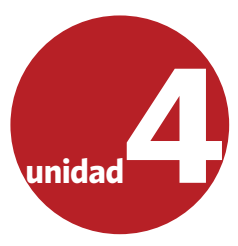

\section{RELACIONES INTERPERSONALES}

El bienestar y la salud sexual dependen de factores individuales o personales, así como de influencias sociales más amplias. Esta unidad pretende ayudar a las y los adolescentes a que desarrollen un grado de comprensión y confianza en sus relaciones. Específicamente, proporciona recursos para ayudarles a reflexionar y fortalecer su comunicación en toda clase de relaciones. Se enfoca especialmente en las formas de superar las complicaciones emocionales de las relaciones íntimas y románticas. 


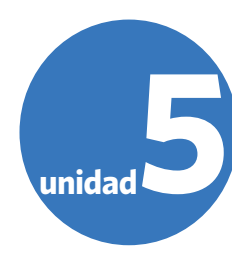

\section{HABILIDADES DE COMUNICACIÓN Y TOMA DE DECISIONES}

Las personas que conversan con sus parejas sobre temas sexuales tienen relaciones más satisfactorias y mejor salud sexual. A la gente joven le gustaría aprender formas de sostener conversaciones sobre temas íntimos en los que pueda sentirse cómoda y segura de sí misma. Sin embargo, rara vez tienen una oportunidad de aprender cómo manejar estas conversaciones que son tan sensibles. Esta unidad se enfoca en el fortalecimiento de las habilidades de comunicación. Se concentra en temas de sexualidad, anticoncepción, VIH y SIDA. También incluye una sección sobre la capacidad de tomar decisiones y actuar en consecuencia.

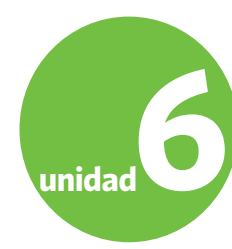

\section{EL CUERPO, PUBERTAD Y REPRODUCCIÓN}

El conocimiento de su cuerpo empodera a la gente joven para proteger su salud y su sexualidad. La unidad 6 incluye la información básica que usualmente ha sido parte de la educación sexual dentro del sistema escolar. Por ejemplo, explica la pubertad y la forma en que funcionan el cuerpo y sus diferentes órganos y sistemas. Sin embargo, el material se presenta tomando en cuenta el contexto social y los derechos humanos, en lugar de restringirse a un marco meramente biológico.

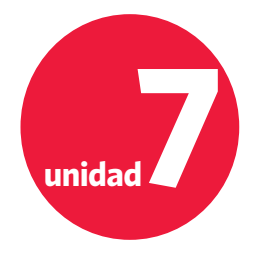

\section{SALUD SEXUAL Y REPRODUCTIVA}

\section{(incluida la prevención del VIH y la anticoncepción)}

Esta unidad proporciona información en dos partes. Los principales temas en la Parte 1 son las infecciones de transmisión sexual, el VIH y el SIDA, así como las infecciones del tracto reproductivo. La Parte 2 cubre la anticoncepción y el aborto. Se destaca la salud preventiva a lo largo de esta unidad.

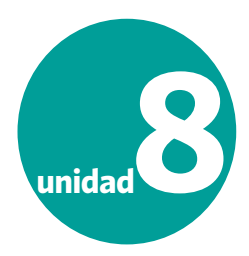

\section{ADVOCACY PARA LA SALUD SEXUAL, DERECHOS E IGUALDAD DE GÉNERO}

Muchas personas jóvenes pueden y desean ayudar a promover los cambios sociales que conducirán a una mejor salud sexual y reproductiva; cambios que también promoverán una mayor justicia e igualdad para todos. Este módulo orienta a educadores, incluidos los y las maestras de civismo y estudios sociales, sobre las formas de usar métodos centrados en el estudiante, con el fin de promover la participación de la gente joven en sus comunidades. Este tipo de experiencias prácticas puede complementar y profundizar en el conocimiento logrado en las unidades anteriores. Puede ofrecer a la gente joven la satisfacción de ver cómo puede provocar un cambio positivo en el mundo.

\section{HOJAS INFORMATIVAS}

Al final del libro de PAUTAS, usted encontrará 22 hojas informativas que sirven como fuentes de referencia técnica adicionales sobre ciertos temas. Cada hoja informativa apoya y está vinculada con subtemas específicos en las Unidades 1-7 de las PAUTAS. Estas hojas están ordenadas alfabéticamente. 


\section{libro de actividades}

\section{MÉTODOS EFECTIVOS DE ENSEÑANZA}

Con frecuencia, los programas de educación en sexualidad y prevención del VIH en el mundo han sido líderes en el uso de métodos de enseñanza participativa que van más allá de las usuales sesiones de clase o de lectura. Al involucrar a la gente joven de manera más activa en su propio aprendizaje, tales métodos incluyen la reflexión personal, el pensamiento crítico y la discusión. Estos procesos pueden fomentar actitudes más igualitarias, así como un cambio de comportamiento, incluso en las áreas de género y salud sexual. De manera más amplia, pueden también ayudar a equipar a la gente joven a enfrentar su mundo cambiante con imaginación y confianza.

Por lo tanto, el libro de ACTIVIDADES de Un sólo currículo comienza con una sección que explica y ofrece orientación sobre enfoques de enseñanza interactivos y centrados en la o el estudiante. (El libro de PAUTAS también incluye "Sugerencias para la enseñanza" al principio de cada unidad de contenido). Estos recursos, sin embargo, no pueden sustituir a una adecuada capacitación y apoyo por parte de educadores.

\section{EJEMPLOS DE ACTIVIDADES}

El libro de ACTIVIDADES incluye 54 actividades de muestra que corresponden a contenidos específicos en el libro de PAUTAS (que se indican por medio de recuadros color naranja a lo largo del libro de PAUTAS). Estas actividades centradas en el estudiante han sido probadas y son fáciles de adaptar a través de diferentes culturas. Pueden ayudar a la gente joven a visualizar los vínculos entre lo que han aprendido y sus propias experiencias y sentimientos. Las actividades son creativas y atractivas para la gente joven.

Las y los maestros pueden usar las actividades tal y como se presentan o pueden adaptarlas. También pueden modelar nuevas actividades basándose en las que se presentan en el kit. Muchas de las actividades involucran lectura o escritura, pero la gran mayoría son adaptables a estudiantes analfabetos.

\section{LISTA ADICIONAL DE RECURSOS}

El volumen de ACTIVIDADES concluye con una lista de recursos técnicos y materiales selectos de todo el mundo. Cada elemento de la lista incluye una breve descripción e información de contacto. 
Personas a cargo de formular políticas y de organizaciones internacionales han pedido que la educación sobre sexualidad, prevención del VIH y vida familiar, sea equitativa en cuanto a género y que esté basada en derechos.

Un sólo currículo: Pautas y actividades responde a ese llamado. Aprovecha hallazgos de investigaciones sobre los factores que determinan el comportamiento sexual. Fomenta que las personas desarrollen capacidades personales - incluyendo la autoconfianza - para construir sociedades justas y solidarias. 


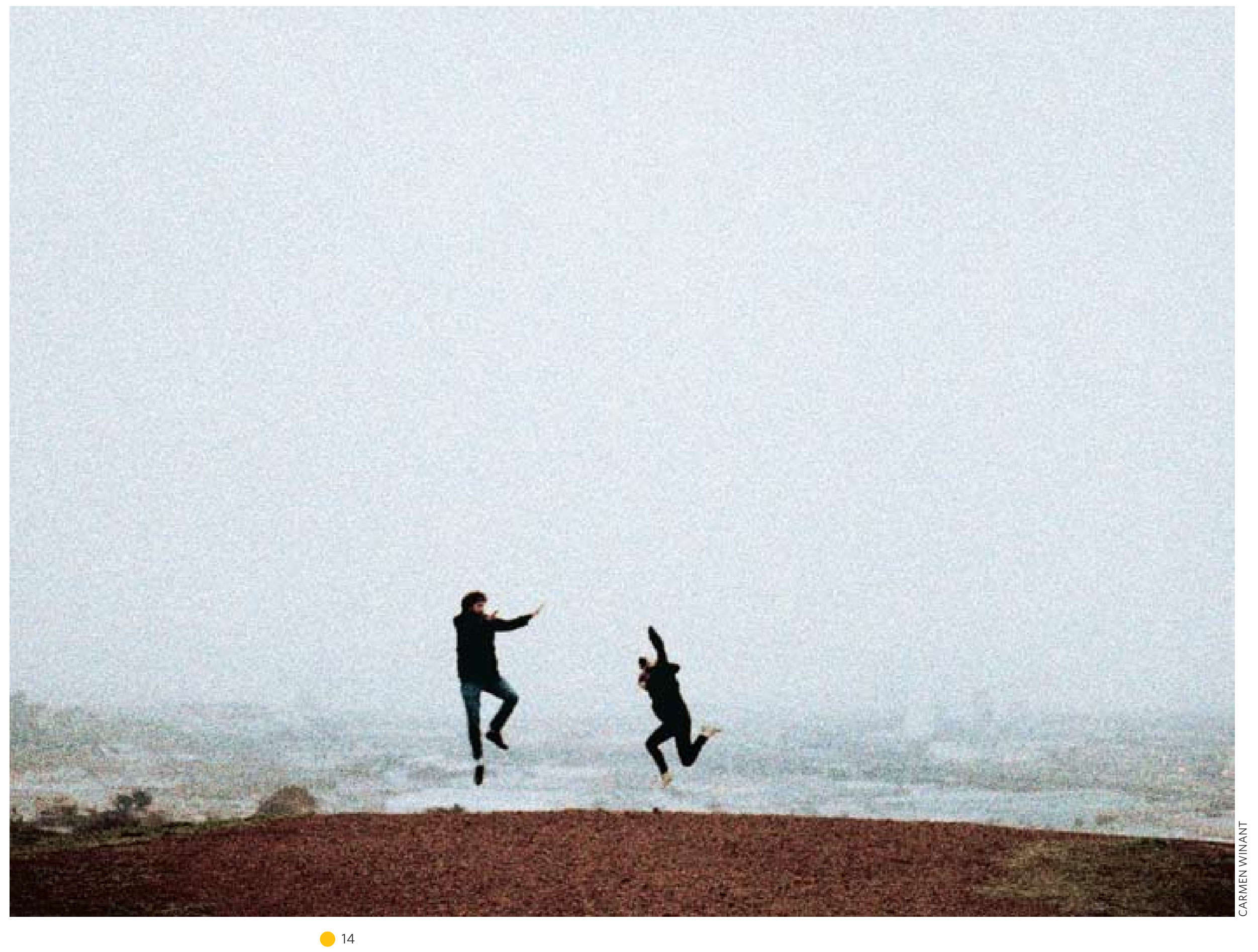




\section{NOTAS FINALES}

$1<$ http://www.un.org/millenniumgoals/>.

2 <http://data.unaids.org/pub/InformationNote/2008/20081031 strategicframework final en.pdf $>$ and $<$ www. unaids.org/en/

KnowledgeCentre/Resources/PolicyGuidance/OperationGuidelines/ gender_operational_guidelines.asp>.

$3<$ www.who.int/reproductive-health/strategy.htm>.

$4<$ http://portal.unesco.org/en/ev.php-URL_ID=33618\&URL_DO=DO TOPIC\&URL SECTION=201.html>. Ver también el énfasis que hace la UNESCO para la educación en derechos humanos y empoderamiento de género en: <http://portal.unesco.org/en/ev.php-URL_ID=33525\&URL DO=DO_TOPIC\&URL SECTION=201.html>.

5 World Association for Sexual Health. 2008. Sexual Health for the Millennium. A Declaration and Technical Document. Minneapolis: World Association for Sexual Health.

6 Senderowitz, J., Kirby, D. 2006. "Standards for curriculum-based reproductive health and HIV education programs." Arlington, VA: Family Health International/YouthNet

7 En diferentes entornos los programas educativos pueden usar términos como "habilidades para la vida", "educación en vida familiar", "educación en salud" o "educación en población". Un sólo currículo permite a las y los profesionales de la educación desarrollar o modificar currículos (o planes de lecciones) para educación bajo cualquiera de estos títulos.

8 Estos derechos humanos han sido respaldados por la mayoría de las naciones y se citan a lo largo de ese documento.

9 Este documento usa el término "igualdad de género" para reforzar el concepto de que todos los seres humanos - sin importar su géner - son iguales y tienen derecho a un trato igualitario. Para efectos del contenido del currículo se propone que este concepto refleje dos elementos que son complementarios, la equidad de género (justicia social) y la iqualidad de oportunidades.

10 Dunkle, K., R. Jewkes, H. Brown, G. Gray, J. Mclntyre y S. Harlow. 2004. "Gender-based violence, relationship power, and risk of HIV infection in women attending antenatal clinics in South Africa," The Lancet 363: 1415-1421; Jewkes, R., C. Vundule, F. Maforah y E. Jordaan. 2001. "Relationship dynamics and teenage pregnancy in South Africa," Social Science \& Medicine 52: 733-744; Karim, A.M., R. Magnani, G. Morgan y K. Bond. 2003. "Reproductive health risk and protective factors among unmarried youth in Ghana," International Family Planning Perspectives 29: 14-24; Koenig, M., I. Zablotska, T. Lutalo, F. Nalugoda, J. Wagman y R. Gray. 2004. "Coerced first intercourse and reproductive health among adolescent women in Rakai, Uganda," International Family Planning
Perspectives 30: 156-163; Martin, S., L. Matza, L. Kupper, J. Thomas, M. Daly y S. Cloutier. 1999. "Domestic violence and sexually transmitted diseases: The experience of prenatal care patients," Public Health Reports 114: 262-268; Pleck, J.H., F.L. Sonenstein y L.C. Ku. 1993. "Masculinity ideology: Its impact on adolescent males' heterosexual relationships," Journal of Social Issues 49: 11-29; Pulerwitz, J. y G. Barker. 2008.

"Measuring attitudes toward gender norms among young men in Brazil: Development and psychometric evaluation of the GEM scale," Men and Masculinities 10(3): 322-338; Stephenson, R., M.A. Koenig, R. Acharya y T.K. Roy. 2008. "Domestic violence, contraceptive use, and unwanted pregnancy in rural India," Studies in Family Planning 39(3): 177-186; Zambrana R.E., C.J. Llewlly, S.S. Boykin y S.D. López. 2004. "Latinas and HIV/AIDS risk factors: Implications for harm reduction strategies," American Journal of Public Health 94: 1152-1158.

11 Ver, por ejemplo, Kirby, D., B. Laris y L. Rolleri. 2007. "Sex and HIV education programs: Their impact on sexual behaviors of young people throughout the world." Journal of Adolescent Health 40: 206-217. Kirby et al., en contraron que dos tercios de los programas resultan en que los estudiantes reportan un cambio en su comportamiento; sin embargo, la mayoría de las evaluaciones que analizaron el efecto de un programa de educación sexual/VIH sobre los resultados en materia de salud reproductiva (específicamente el embarazo no planeado o las infecciones de transmisión sexual) no pudo demostrar un impacto estadísticamente significativo.

12 Jewkes, R., M. Nduna, J. Levin, N. Jama, K. Dunkle, A. Puren y N. Duvvury. 2008. "Impact of Stepping Stones on incidence of HIV and HSV-2 and sexual behaviour in rural South Africa: Cluster randomised controlled trial," British Medical Journal 337(a506): 1-11; Pulerwitz,

J., G. Barker, M. Segundo y M. Nascimento. 2006. "Promoting more gender-equitable norms and behaviors among young men as an HIV/ AIDS prevention strategy," HORIZONS Final Report. Washington, DC Population Council. También, ver la lista de programas innovadores en los Recursos Adicionales al final del libro de ACTIVIDADES.

13 Los ODM son una lista de ocho objetivos (que incluyen la erradicación de la pobreza extrema y el hambre, el logro de la educación primaria universal, la promoción de la igualdad de género y el empoderamiento de las mujeres; y el mejoramiento de la salud materna) aprobados por la Asamblea General de las ONU. Los ODM comprometen a la comunidad internacional con una visión expandida del desarrollo y han sido aceptados comúnmente como un marco de referencia para medir el avance del desarrollo.

14 Ver notas finales $1-5$

15 Dependiendo de la demanda, puede desarrollarse una versión separada para la enseñanza de estudiantes más jóvenes. Por favor comuníquese con las editoras para mayor información. 


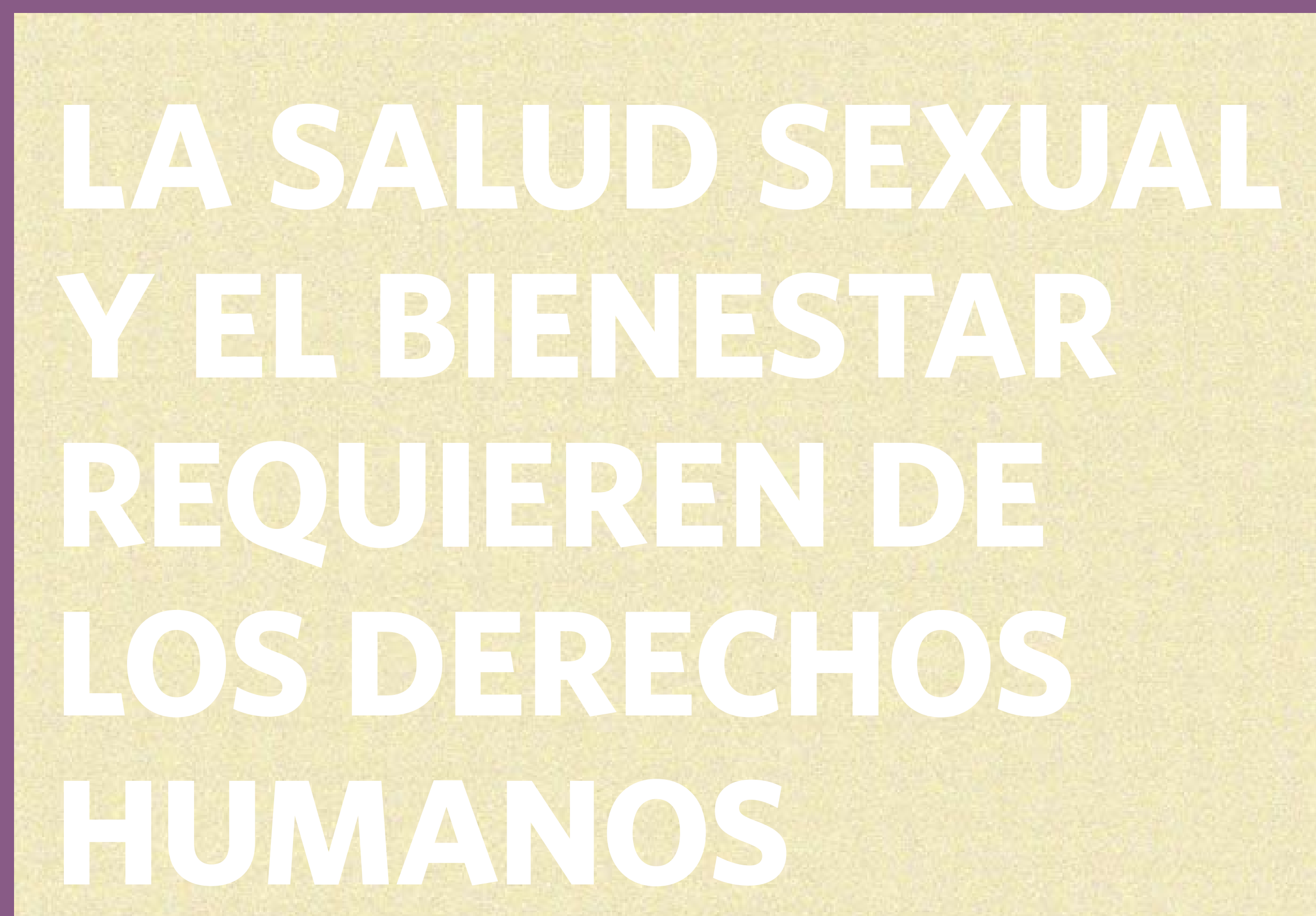




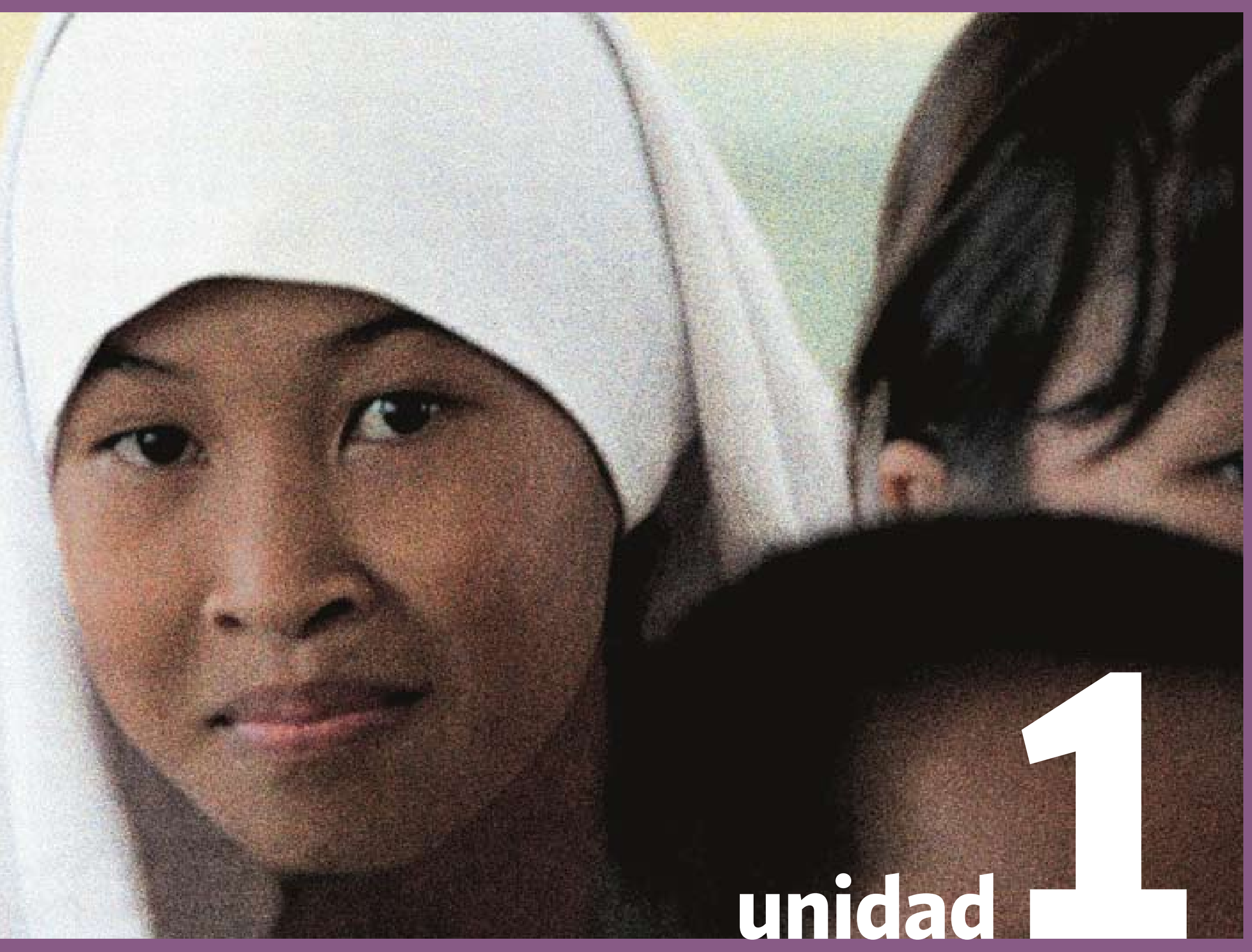




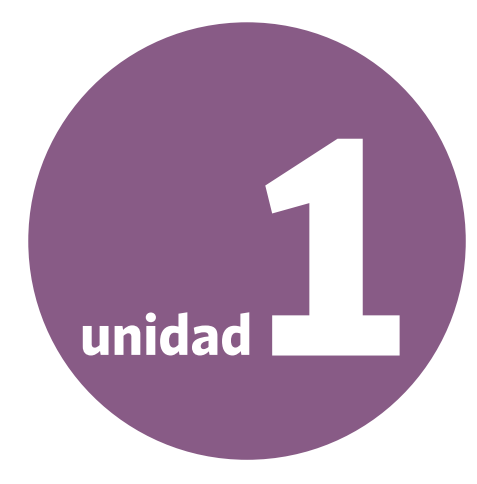

\section{visión general}

¿Por qué la educación en sexualidad y la prevención del VIH deben poner énfasis en los derechos humanos? Para gozar de vidas sexuales seguras y satisfactorias, la gente joven tiene que poder ejercer sus derechos humanos básicos. Por ejemplo, toda persona tiene derecho a la dignidad, a su seguridad corporal y al acceso a información y servicios de salud. Solamente cuando las personas pueden ejercer estos derechos es que pueden realmente elegir en tener o no relaciones sexuales, negociar el uso del condón y de anticonceptivos y buscar los servicios que necesitan. Promover los derechos sexuales y los derechos reproductivos también alienta a la gente joven para que se responsabilice de la protección del bienestar y derechos de otras personas. Desafortunadamente, cientos de millones de personas, especialmente jóvenes, todavía siguen siendo vulnerables a abusos como las relaciones sexuales forzadas (que con frecuencia aumentan su riesgo de contraer el VIH o quedar embarazadas), la violencia, el matrimonio infantil y el estigma relacionado con su comportamiento sexual. Cuando se violan los derechos de las personas, su capacidad de gozar de una sexualidad segura y satisfactoria se ve afectada para toda su vida.

El conocimiento de los derechos humanos permite que la gente joven adquiera la sensación de que es importante en el mundo. Esta unidad proporciona una visión general básica sobre los derechos sexuales y humanos; y explora su vinculación con las prácticas relacionadas a la sexualidad y la salud. 


\section{LA SALUD SEXUAL Y EL BIENESTAR REQUIEREN DE LOS DERECHOS HUMANOS}

Los conceptos de derechos humanos y derechos sexuales están reconocidos a nivel internacional. Se aplican en todas las regiones del mundo, incluidas África, las Américas, Asia, Europa, el Mundo Árabe y el Pacífico. Pero mucha gente no conoce el significado de estos conceptos, o la forma en que afectan sus propias vidas. Usted puede familiarizarse con estos temas mediante la lectura del material contenido en esta breve unidad.

Esté consciente de sus propios sesgos. Pregúntese constantemente cuál es la base de sus opiniones acerca de otras personas.

Recuerde que los derechos humanos se aplican a todas las personas. Por lo tanto, no se le pueden quitar a persona alguna. Sin embargo, no toda la gente puede ejercer estos derechos a plenitud.

Ponga énfasis en que los seres humanos también tienen responsabilidades, incluido el respeto a otras personas y a los derechos de todos.

Prepárese para expresarse con franqueza acerca de la forma en que las instituciones sociales, como los clubes sociales, las organizaciones religiosas y otros grupos pueden minar los derechos de otras personas o permitir la discriminación.

Conduzca alguna investigación de contexto para identificar violaciones a los derechos humanos que estén relacionadas con temas de sexualidad en su país - por ejemplo, de matrimonio forzado, violencia sexual o la situación de personas que viven con el VIH y SIDA.

Recurra a ejemplos concretos sobre temas de derechos humanos - tomados ya sea de actividades presentadas en el libro de ACTIVIDADES o de su propio entorno. Ponga énfasis en situaciones reales que puedan ayudar a que las y los participantes comprendan que los derechos humanos son más que una idea abstracta.

Como parte de la enseñanza de los derechos humanos, ayude a que los participantes aprecien que ellos mismos ¡tienen poder y que son importantes en el mundo!

Varias de las hojas informativas al final de este libro proporcionan detalles adicionales sobre estos temas. 


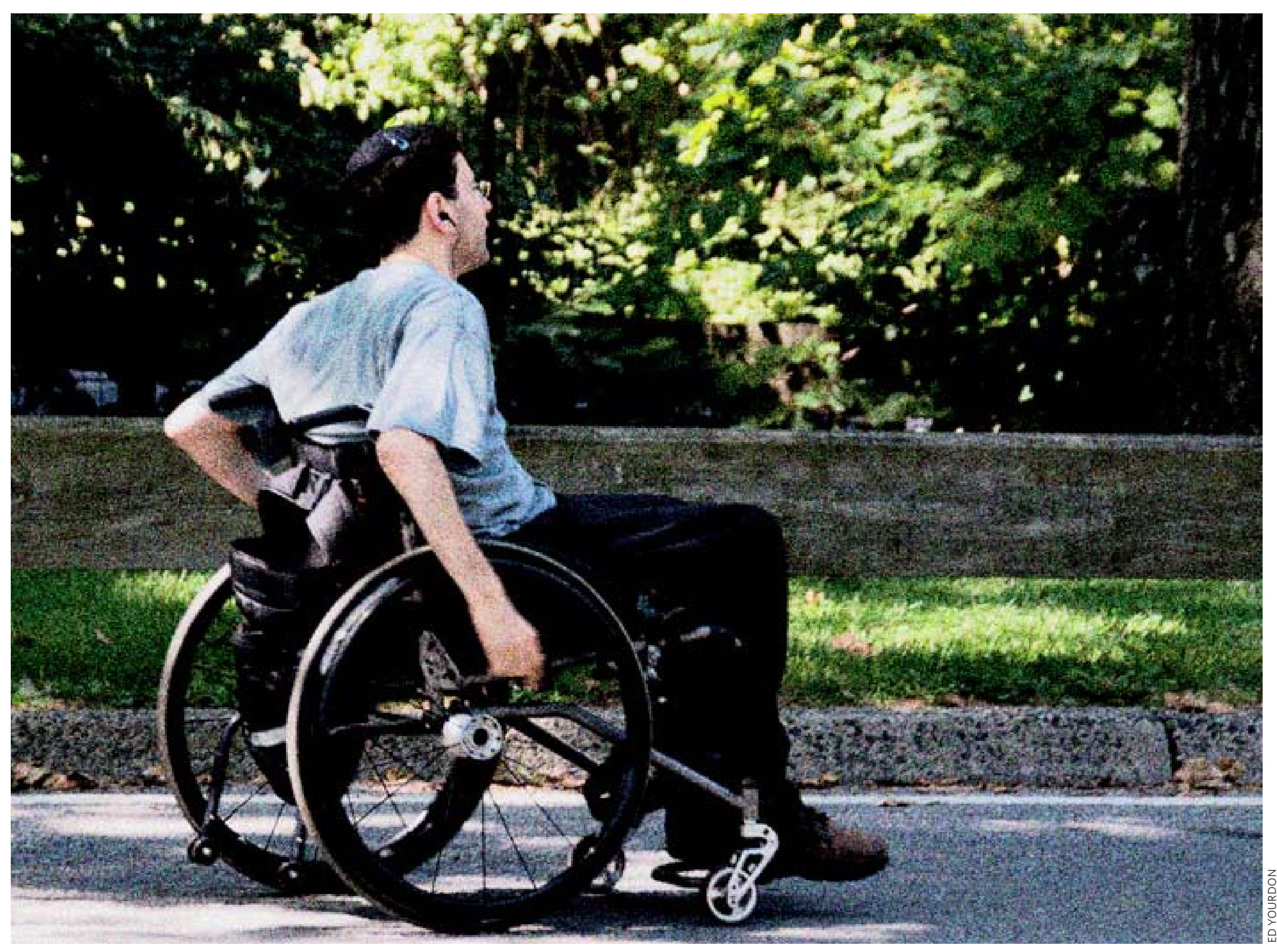




\section{LA SALUD SEXUAL Y EL BIENESTAR REQUIEREN DE LOS DERECHOS HUMANOS}

El material en esta unidad prepara a las y los participantes para:

\section{Objetivos cognoscitivos}

Identificar cinco derechos básicos de todo ser humano, incluidos dos que sean derechos sexuales o reproductivos.

Analizar en grupo al menos dos circunstancias en las que las personas pueden ejercer sus derechos sexuales o reproductivos y dos en las que no pueden hacerlo. Explicar de qué forma estas situaciones pueden afectar su salud sexual o reproductiva.

Describir un ejemplo de cambio en alguna ley o política que afecte las vidas sexuales o reproductivas de las personas.

Indique una persona u organización a la cual acudir o llamar si los derechos sexuales de alguna persona son ignorados.

Analizar en grupo qué responsabilidades tiene el Estado de proteger, respetar y cumplir con estos derechos; y qué responsabilidades tienen las personas (elegir por lo menos dos derechos para este análisis).

\section{Objetivos afectivos}

Comprender la importancia del respeto en la interacción humana, incluidas las relaciones románticas y las sexuales.

Analizar en grupo sus sentimientos, respecto a si es justo tratar a la gente de manera diferente o desigual.

Analizar en grupo sus propios sentimientos y actitudes respecto a la violación de un derecho sexual o reproductivo que les sea importante y las consecuencias de esta violación.

Describir lo que consideran que significa una vida plena y satisfactoria para ellos mismos.

Objetivos basados en destrezas

Hablar de manera efectiva acerca de sus ideas relacionadas con la igualdad, discriminación y otros aspectos de los derechos humanos. 


\section{cómo nos tratamos unos a otros: valores y sociedad}

Podemos plantear muchas preguntas acerca de la forma en que nos tratamos unos a otros en la sociedad. Estas preguntas se aplican independientemente de la región del mundo en que vivimos. Algunas de estas preguntas se indican a continuación.

1 ¿Qué es lo que la mayoría de la gente, incluida la gente joven, desea?

- La mayoría de la gente joven desea una buena calidad de vida. Algunas veces a esto se le llama "bienestar".

- Para la mayoría de nosotros, el bienestar significa tener la oportunidad de ser saludables y felices. Queremos estar seguros y ser respetados. Queremos tener oportunidades para crecer y aprender. Queremos ser importantes en el mundo y perseguir nuestros sueños. Y queremos vivir juntos en paz. Queremos todo esto para nosotros mismos, nuestras familias y nuestras comunidades.

- La salud sexual y bienestar son una parte importante del bienestar en general.

\section{PUNTOS PARA REFLEXIÓN}

¿Tienen todas las personas derecho a buscar la felicidad y perseguir sus sueños?

¿Qué significa para alguien "ser importante" para otras personas?

¿Qué responsabilidad tenemos de tratar a todas las personas con respeto?

¿Debe toda persona gozar de seguridad?

¿Debe toda persona poder influir de manera justa en el establecimiento de reglamentos y leyes?

¿Deben dividirse los recursos de manera justa?

¿Debe toda persona poder tomar decisiones básicas para proteger su propio cuerpo y futuro?

Estas preguntas también se aplican a la vida íntima y sexual de las personas.
2 ¿De qué manera debemos vivir juntos - en nuestras familias, comunidades y sociedades - para lograr que todas las personas tengan oportunidad de una buena calidad de vida o bienestar? 
3 ¿En dónde aprendemos nuestras ideas sobre cómo debemos comportarnos y tratarnos unos a otros? ¿En dónde aprendemos qué responsabilidades tenemos unos hacia los otros?

- Cada uno de nosotros tiene sus propias creencias acerca de lo que está bien o mal. Estas creencias incluyen valores y actitudes que tienen que ver con el cuerpo, la sexualidad y las relaciones íntimas.

- Con frecuencia tendemos a pensar que nuestros propios valores y creencias son "naturales". Sin embargo, están profundamente influidos por nuestras familias, comunidades y sociedad.

- Las actitudes de nuestras familias, comunidades y sociedad se llaman "normas sociales" [ver glosario.]

- Las sociedades promulgan leyes que reflejan normas y especifican cuáles comportamientos son permitidos y cuáles no lo son. Con frecuencia, aquellas personas o grupos que ostentan mayor poder tienen la mayor influencia en la determinación tanto de las normas sociales como de las leyes. Algunas leyes, normas y valores individuales tienen que ver con la sexualidad.

- Las normas sociales cambian a través del tiempo. También varían a través de las culturas y dentro de ellas.

- Aunque todos nos vemos influenciados por las normas sociales, cada uno de nosotros puede desarrollar también sus propias ideas independientes acerca de la manera más justa de comportarse y tratar a otras personas. Podemos captar ideas de muchas fuentes, incluidos los modelos de conducta, libros y la reflexión personal.

\section{Algunos principios éticos sobre la forma en que las personas deben tratarse unas a otras son} considerados en general como universales. Estos principios se llaman derechos humanos.

[Ver la siguiente sección.]

Ver el glosario al final de esta unidad para una sencilla introducción a conceptos y términos claves. Note también: Es importante destacar que, si bien se ha hecho el esfuerzo de utilizar un lenguaje de género equilibrado, con el objeto de facilitar la fluidez de la lectura y optimizar la extensión de este documento, en ocasiones se hace referencia solamente a la forma masculina de los sujetos; por ejemplo, "los educadores", "los jóvenes" o "los prestadores de servicios"; sin embargo, en todo momento se tiene presente al género femenino.

VER EL LIBRO DE ACTIVIDADES Actividad 1

por qué es importante la justicia

Las y los participantes pueden reflexionar sobre el tema de justicia respondiendo a citas de personas prominentes. 


\section{¿Qué son los "derechos humanos"?}

VER EL LIBRO DE ACTIVIDADES

\section{Actividad 2}

introducción a los derechos humanos

Las y los participantes desarrollan una lista de derechos para un país nuevo y comparan su lista con la Declaración Universal de los Derechos Humanos.

Entrevistan a personas adultas

sobre su comprensión del término "derechos humanos".

\section{VER EL LIBRO DE ACTIVIDADES}

\section{Actividad 3}

poder, privilegio e igualdad

Las y los participantes identifican y

reflexionan sobre la relación entre

el poder social y la experiencia de

privilegio o discriminación.
1 Todo ser humano tiene derechos y protecciones básicos.

Estos derechos incluyen pero no están limitados a:

- trato igual ante la ley;

- alimento, agua, cobijo y vestido;

- ser tratado con respeto y dignidad;

- vivir libre de tortura;

- libertad de expresión;

- libertad de pensamiento, conciencia y religión;

- derecho a reunirse y participar en la sociedad;

- derecho a la educación; y

- derecho a la salud, incluido el acceso a información y servicios de salud.

2 Estos derechos humanos son universales. Esto significa que se aplican a todos nosotros, sin importar nuestro sexo, edad, estado civil, identidad o comportamiento sexual, identidad de género, raza, origen étnico, origen nacional o social, convicciones políticas, ciudadanía, creencias religiosas, condición social o económica, lugar en donde vivimos, nuestra capacidad física y mental, o nuestra condición de salud. ${ }^{1}$ Estos derechos no son condicionales y no se nos pueden quitar.

- Muchas personas han oído acerca de los derechos humanos, por ejemplo, en conversaciones relacionadas con la tortura.

- Los derechos humanos también se extienden a los derechos económicos y los derechos sociales. Estos incluyen el derecho a la educación y a la atención en salud. También incluyen derechos sexuales y derechos reproductivos específicos. 
3 Los derechos humanos básicos han sido acordados por la comunidad global de estados (a través de las Naciones Unidas). Están formalizados en acuerdos internacionales y ratificados formalmente por la mayoría de los gobiernos. ${ }^{2}$

[Ver la hoja informativa sobre Acuerdos de las Naciones Unidas.]

4 Las y los niños tienen derechos humanos. Los derechos de las y los niños han sido establecidos en acuerdos internacionales, incluida la Convención sobre los Derechos del Niño (CDN). Los derechos en la CDN se aplican a todas las personas menores de 18 años de edad.

\section{Aunque todos nosotros debemos poder gozar de nuestros derechos humanos, no} siempre podemos hacerlo.

6 Parte de la responsabilidad de proteger, respetar y cumplir con los derechos humanos descansa en los gobiernos. En realidad, sin embargo, los países varían en el grado en el que cumplen con esta responsabilidad.

Por ejemplo, algunos gobiernos han aprobado leyes que restringen los derechos de ciertas personas, por ejemplo, al:

- prohibir las protestas públicas;

- prohibir la organización de sindicatos laborales;

- penalizar la actividad sexual consensual entre personas adultas del mismo sexo; y

- perdonar o tratar de manera indulgente el asesinato de una mujer o niña a manos de su pareja masculina u otro miembro de su familia cuando él percibe que su acción es un asunto de "honor".
2 Los documentos relevantes de derechos humanos, legalmente obligatorios, incluyen (con sus siglas en inglés): el Pacto Internacional de Derechos Económicos, Sociales y Culturales (ICESCR, 1966); Convención sobre la Eliminación de Todas las Formas de Discriminación en Contra de las Mujeres (CEDAW, 1979); Convención sobre los Derechos del Niño (CRC, 1989). Otro documento de derechos humanos, importante pero no obligatorio, es la Declaración Universal de los Derechos Humanos (UDHR). Para consultar una copia de la UDHR ver la Actividad 2 en el volumen que acompaña a éste. [Ver referencias a derechos específicos en las secciones relevantes a través de las unidades 1-7.]

\section{PUNTOS PARA REFLEXIÓN}

¿Qué derechos humanos básicos comparten las y los niños (incluidos los adolescentes) con las personas adultas?

¿Qué derechos adicionales piensa usted que tienen las y los niños, mismos que deben ser respetados específicamente porque todavía son niños? Por ejemplo, ¿qué oportunidades básicas necesitan las y los niños para poder sentirse felices?

¿Qué clase de oportunidades necesitan las y los niños para tener una mejor oportunidad de una vida plena y satisfactoria? ¿Algunas veces las y los niños experimentan peligros o apuros de los que deban estar protegidos?

¿Cómo podemos desarrollar la capacidad, madurez y responsabilidad de las y los niños y jóvenes para comprender y proteger sus propios derechos y los derechos de otras personas? Proporciona uno o dos ejemplos. 
7 La condición social y económica de las personas puede también limitar su capacidad para gozar de sus derechos.

Por ejemplo, su nacionalidad, sexo, raza, religión, edad, clase/casta, opinión política, identidad sexual, condición de VIH o su capacidad física o mental influye típicamente en sus oportunidades para:

- obtener educación y ganarse un buen nivel de vida;

- recibir trato igualitario y justo ante la ley;

- vivir libre de violencia;

- sentirse respetadas y tratadas con dignidad; y

- sentir que pueden perseguir y alcanzar sus sueños.

8 Toda persona tiene la responsabilidad de respetar los derechos de todas las demás personas. $^{3}$

- Cuando crecemos aprendiendo a respetar a todo ser humano con igualdad, llegamos a respetar los derechos humanos.

- Con frecuencia, cuando crecemos aprendiendo a mantener actitudes negativas hacia ciertos grupos de personas, puede suceder que les tratemos de manera injusta y negarles sus derechos.

- Algunas veces las personas atribuyen un conjunto de características a cierto grupo de seres humanos. Esto se llama "estereotipar". Ejemplos comunes de la aplicación de estereotipos incluyen la percepción de que, de manera natural, los niños son mejores que las niñas en matemáticas y que ciertos grupos son flojos o sucios. Típicamente, los estereotipos son inexactos o están severamente distorsionados. El estereotipar nos hace menos capaces de ver a otras personas como humanos a plenitud. Nos hace más propensos a aceptar o disculpar el trato injusto hacia otras personas.

- Algunas personas pueden ser víctimas de una severa desaprobación social debido a sus características personales. Esta desaprobación se llama estigma. Por ejemplo, en algunos lugares las personas pueden ser víctimas de estigma debido a su peso corporal, a su comportamiento sexual, a su religión, a su condición de salud, o incluso debido a su falta de capacidad en los deportes.

- Cuando las personas son tratadas injustamente debido a su identidad supuesta (o conocida), ese trato se llama "discriminación". Las personas tienen derecho a vivir libres de discriminación. La discriminación ocurre dentro de las familias, en la escuela, en el trabajo, en la comunidad y en la sociedad en general.

- La discriminación no es solamente un asunto individual. Los gobiernos y los sistemas sociales como un todo (como el sistema escolar, las religiones o el mercado de trabajo) también discriminan.

- Independientemente de nuestras actitudes personales, todos tenemos la responsabilidad de respetar los derechos humanos de las personas.

3 "Comprendiendo que el individuo, por tener deberes respecto de otros individuos y de la comunidad a que pertenece, tiene la obligación de esforzarse por la consecución y la observancia de los derechos reconocidos en este Pacto". (ICESCR, 1966; ICCPR, 1966). 


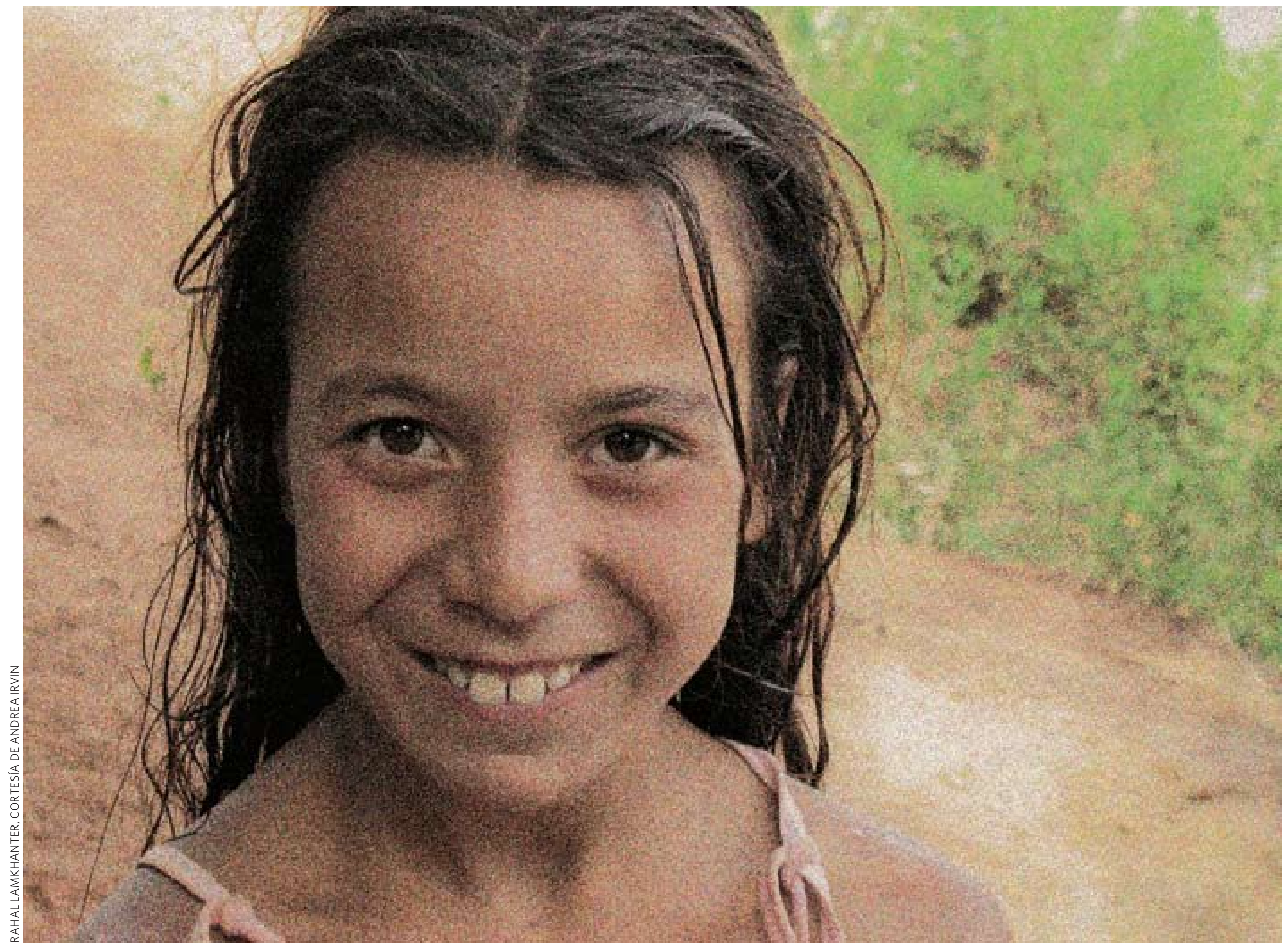




\section{derechos sexuales y derechos reproductivos}

1 Las experiencias románticas y sexuales de las personas pueden convertirse en temas de derechos humanos. Solamente cuando nuestros derechos básicos son respetados (tanto por los gobiernos como por otros individuos) podemos tomar decisiones óptimas sobre las relaciones íntimas, las relaciones sexuales y la maternidad.

Por ejemplo:

- Las personas pueden tomar decisiones sobre si formarán un romance, una relación a largo plazo o un matrimonio, así como cuando y con quién lo harán. Pueden evitar casarse demasiado jóvenes o hacerlo en contra de su voluntad. O pueden tener una relación íntima con alguien del mismo sexo.

- Pueden decidir si tener relaciones sexuales (libres de abuso y coerción sexual), así como cuándo, con quién y bajo qué circunstancias hacerlo. Pueden negociar el uso del condón para evitar la infección. Son libres de tener relaciones sexuales con alguien del mismo sexo.

- Pueden decidir si embarazarse o tener hijos, o cuándo hacerlo. Pueden obtener información y servicios anticonceptivos. Pueden tener un aborto seguro. Pueden adoptar a un hijo sin importar su estado civil o identidad sexual.

2 Cuando los derechos humanos se relacionan con la sexualidad o reproducción de las personas, los llamamos "derechos sexuales" o "derechos reproductivos".

- Algunas veces los derechos sexuales y los derechos reproductivos se traslapan. Sin embargo, los derechos sexuales generalmente incluyen el control de las personas sobre actividad sexual y su salud sexual. Los derechos reproductivos usualmente se refieren a controlar las decisiones relacionadas con la fecundidad y la reproducción.

- El principio de consentimiento entre adultos es central para los derechos sexuales y reproductivos. El acceso a la información y los servicios también es un factor de importancia crítica.

- Muchos de estos derechos son reconocidos en acuerdos internacionales. ${ }^{4}$

4 Tales acuerdos incluyen, por ejemplo la Convención sobre la Eliminación de Todas las Formas de Discriminación en Contra de las Mujeres (CEDAW); el Programa de Acción de la Conferencia Internacional sobre Población y Desarrollo (ICPD); y la Plataforma para la Acción de la Cuarta

Conferencia Mundial sobre la Mujer (FWCW).

\section{Los derechos sexuales y reproductivos también se aplican a la gente joven.}

- Las y los niños tienen el derecho de desarrollar un sentido positivo de sus propios cuerpos y sexualidad. Tienen el derecho de vivir libres de abuso y de manoseo inapropiado.

- Las y los niños más jóvenes necesitan ayuda para tomar decisiones. La dirección y orientación provista por adultos solidarios tienen que tomar en cuenta el interés superior del niño. Deben considerar también la capacidad de las y los niños de ejercer sus derechos en su propio nombre.

- Conforme las y los niños crecen y desarrollan sus capacidades, sus derechos y responsabilidades continúan evolucionando.

- La gente joven tiene derecho de obtener información para proteger su salud, incluida su salud sexual y reproductiva. 
4 En el mundo real, las personas - hombres y mujeres - enfrentan muchas barreras para ejercer sus derechos sexuales y sus derechos reproductivos. Con frecuencia, las consecuencias de estas barreras son graves.

- Millones de personas experimentan violencia sexual (violencia o asalto que incluye, pero que no se limita a, relaciones sexuales que son forzadas o que tienen lugar sin el consentimiento o bajo amenaza de violencia). [También ver la Unidad 2, páginas 70-71 y la Unidad 3, páginas 106-107.]

- La violencia sexual afecta a las personas de ambos sexos, a cualquier edad y en todas las condiciones sociales y estilos de vida. Sin embargo, la mayor proporción de personas afectadas son las niñas y las mujeres.

- Las personas experimentan violencia sexual en muchos entornos. La violencia ocurre dentro del hogar, así como dentro de instituciones como prisiones, campos de refugiados, casas de culto religioso, burdeles y ambientes escolares inseguros.

- Con frecuencia, la pobreza aumenta el riesgo de la gente joven (especialmente de las niñas) de experimentar relaciones sexuales que son indeseadas, abusivas o inseguras. La gente joven que vive en condiciones de pobreza tiene más probabilidad de necesitar intercambiar sexo por favores o bienes materiales para sobrevivir.

- Las niñas que viven en condiciones de pobreza tienen más probabilidades que otras niñas de ser víctimas de matrimonio temprano o forzado, embarazo no deseado, aborto inseguro y trata de seres humanos con fines de explotación sexual. [Ver hoja informativa sobre Trata de Seres Humanos con Fines de Explotación Sexual.]

- Las parejas sexuales de algunas personas (incluidas aquellas que pagan por favores sexuales con dinero o regalos) se rehúsan a usar condón. - Algunas personas sufren de estigma, vergüenza, temor o violencia debido a que su identidad (o comportamiento) sexual no se ajusta a las normas sociales locales. Por ejemplo, las personas que se perciben como homosexuales o personas que adoptan una identidad de género diferente (personas transgénero) pueden ser sujetas a tal tipo de trato o sentimientos adversos.

- En algunos entornos, la violencia física contra las mujeres embarazadas es particularmente común.

- En algunos entornos, muchas o la mayoría de las niñas se ven forzadas a que sus genitales sean cortados. [Ver hoja informativa sobre Mutilación Genital Femenina.]

- Muchas personas enfrentan discriminación cuando tratan de buscar información y servicios de salud sexual que les son necesarios. Este problema es especialmente grave en el caso de la gente joven y en personas que viven con el VIH y el SIDA.

5 Desafortunadamente, tales barreras económicas y sociales y tales violaciones de los derechos humanos son tan comunes que típicamente son perdonadas, pasadas por alto o vistas como "normales" culturalmente. Estas barreras y violaciones toman diferentes formas alrededor del mundo.

6 Para controlar y proteger nuestros propios cuerpos, todos necesitamos ser tratados con dignidad y respeto. Esto es un derecho de toda persona como ser humano. 


\section{PUNTOS PARA REFLEXIÓN}

Nuestras actitudes sobre los roles masculinos y femeninos afectan nuestro comportamiento sexual y nuestra salud sexual.

Los resultados de investigaciones muestran que la gente joven que cree en los roles de género "tradicionales" o "conservadores" (por ejemplo, que los niños deben actuar rudamente 0 que las mujeres deben ser sumisas respecto a los hombres) tienden a tener más problemas de salud sexual. Estas personas tienen menor probabilidad de usar condones o anticonceptivos. Tienen mayor probabilidad de involucrarse en relaciones íntimas que son violentas. Las personas que participan en relaciones con un alto nivel de control masculino tienen mayor probabilidad de ser infectadas con el VIH y de reportar embarazos no planeados. De manera similar, la violencia de pareja se asocia con tasas más altas de embarazos no planeados, ITS y VIH. ${ }^{5}$

En contraste, las personas que tienen actitudes más "liberales" acerca de los roles de género o que creen en la igualdad, tienen menor probabilidad de sufrir estas consecuencias. Por lo general, estas personas gozan de mejores resultados en materia de salud sexual que sus pares.

¿Cómo podrían explicarse estas consecuencias?

5 Pleck et al., 1993; Martin et al., 1999; Jewkes et al., 2001; Karim et al., 2003; Dunkle et al., 2004; Koenig et al., 2004; Zambrana et al., 2004; Stephenson et al. 2006; Pulerwitz and Barker, 2008.
- 7 Todas las personas deben tener la oportunidad de aprender sobre los temas que afectan sus sentimientos, experiencias y salud sexual. En especial, la gente joven se beneficia con la oportunidad de pensar en estos temas y tratarlos a profundidad. Las y los jóvenes merecen desarrollar la capacidad de tomar decisiones informadas. Todas las personas tienen derecho a desempeñar un rol en su propio bienestar.

Estos temas incluyen:

- normas y roles de género;

- derechos humanos, especialmente los derechos sexuales y los derechos reproductivos;

- responsabilidades del Estado y de cada persona, de respetar estos derechos;

- el cuerpo humano y la sexualidad (incluidas la pubertad y reproducción, intimidad y placer, formas de prevenir y terminar un embarazo no planeado e información sobre el VIH y el SIDA);

- desarrollo de una mayor comodidad con nuestros propios cuerpos y con nuestros propios valores en evolución; y

- fortalecimiento de nuestra capacidad de actuar a nombre de nosotros mismos, de nuestras familias y de nuestras comunidades.

8 Aprender sobre nuestros derechos y ser capaces de ejercerlos puede tener un efecto profundo y positivo en nuestra salud sexual y reproductiva. 


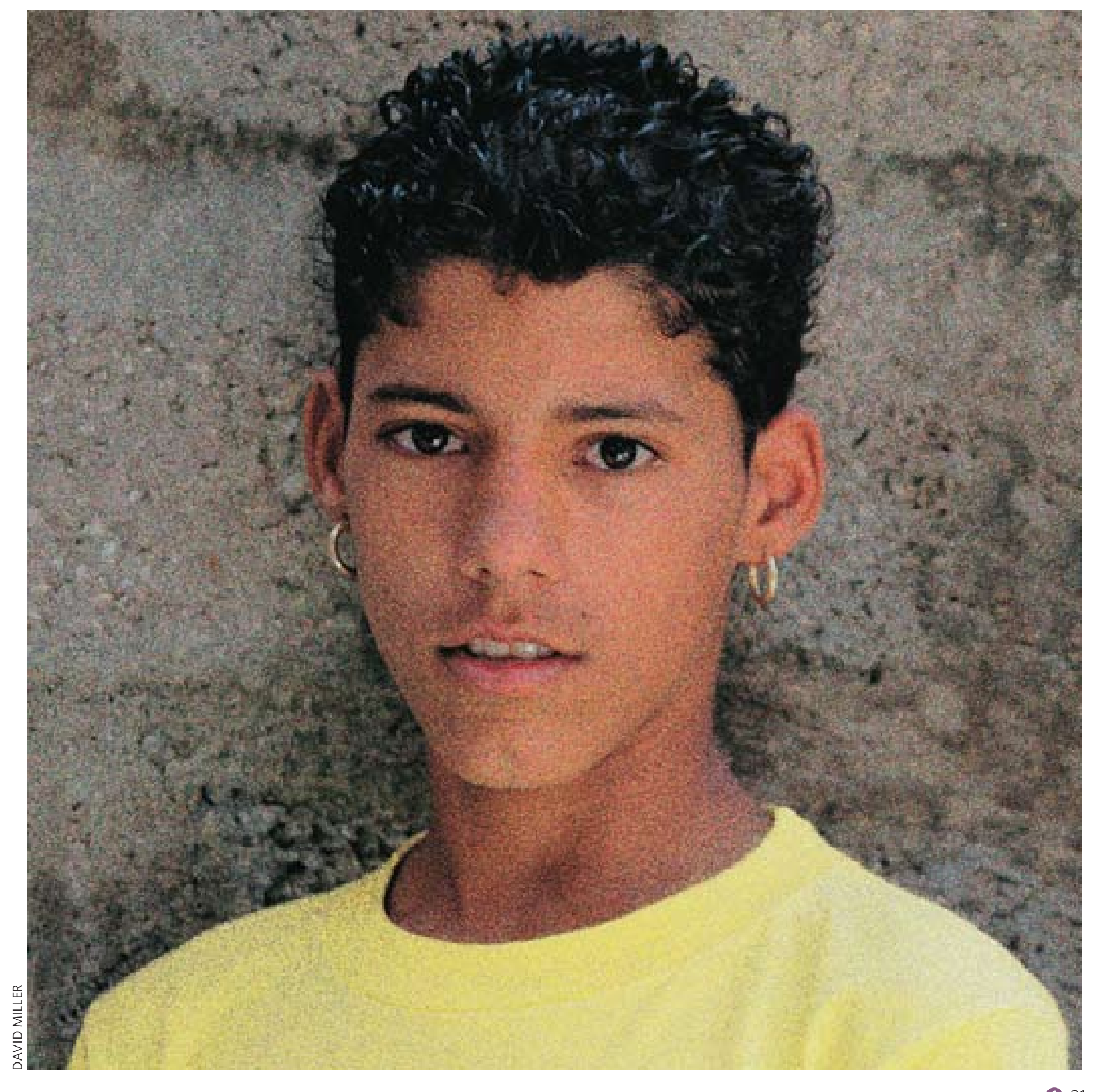

VER EL LIBRO DE ACTIVIDADES Actividad 4

estudios de caso relacionados con los derechos sexuales y reproductivos

Las y los participantes examinan $y$ analizan en grupo historias verdaderas que incluyan violaciones de los derechos sexuales o reproductivos. 


\section{PUNTOS PARA REFLEXIÓN}

Piensa en tus propios valores y sobre la justicia en tu vida.

Pregúntate ¿Qué es lo que quiero? ¿Qué necesito? ¿Qué es lo que me gusta? ¿Cuáles son mis valores? ¿Qué admiro en otras personas? ¿En qué quiero convertirme? ¿Qué barreras enfrento para lograr mis metas?

¿Cómo puedo superar esas barreras?

¿Qué estereotipos tengo hacia ciertos grupos de personas?

Hacer frente a nuestros propios sesgos puede ser difícil. Pero toda persona es capaz de la auto reflexión, crecimiento y cambio. Conforme reflexionamos y crecemos, nos vamos sintiendo más cómodos con nosotros mismos y con otras personas.

¿Puedes recordar alguna ocasión en la que tus derechos o los de otra persona estaban siendo violados?

¿Te parece fácil o difícil manifestarse ante un abuso en contra de los derechos humanos? ¿Qué es lo que lo hace difícil? ¿Qué lo facilitaría?

\section{promoción de los derechos humanos, incluidos los derechos sexuales y los derechos reproductivos}

-1 Muchas personas se preocupan por la justicia y por los derechos básicos de los seres humanos.

2 Nosotros podemos promover la justicia y los derechos humanos en la vida diaria, incluso en la vida sexual y reproductiva.

- Podemos defender a un amigo o compañero de clase que esté siendo tratado de manera injusta, por ejemplo que esté siendo ridiculizado porque se percibe que es homosexual, o a una adolescente expulsada de la escuela porque esté embarazada, o a un maestro que enfrente discriminación porque esté viviendo con el VIH o SIDA.

- Podemos ayudar a otras personas a darse cuenta de que tienen otras oportunidades u opciones en la vida diferentes a las que se les estén presentando. Podemos apoyar a un compañero de clase que se sienta presionado para casarse o para unirse a una pandilla.

- Podemos identificar a personas (u organizaciones) confiables, que puedan apoyarnos para enfrentar a incidentes de discriminación.

3 También podemos promover la justicia y los derechos humanos en nuestras comunidades. A veces, podemos hacer esto por nuestra cuenta o, en otras ocasiones, a través de alguna organización.

- Podemos acompañar a una amiga en una visita a algún funcionario escolar, a la policía, a una clínica de salud, o a otro servicio.

- Podemos hablar con personas que conocemos en la comunidad sobre derechos humanos y sobre los temas que nos preocupan.

- Podemos pedir a un líder local que se pronuncie respecto a un problema como la violencia doméstica.

- Podemos asegurarnos que toda la gente en la comunidad (incluidos nosotros mismos) sepa acerca de los derechos humanos y comprenda que cada persona en la comunidad es importante. 
Ver la unidad 8 para antecedentes con mas detalle y guías para tomar acción.

4 Podemos unirnos a organizaciones o grupos que luchan por los derechos sexuales $\mathrm{y} / \mathrm{o}$ los derechos reproductivos mediante la utilización de varias tácticas.

Algunos ejemplos de esto incluyen:

- participar en marchas de protesta contra los crímenes de odio;

- realizar proyectos de teatro con adolescentes, enfocados a lo que implica vivir con el VIH o el SIDA;

- participar en campañas de conciencia comunitaria sobre prevención de la mutilación genital femenina; y

- participar en "grupos de vigilancia" comunitaria que monitoreen e intervengan en aspectos como prevención o detección de la violencia doméstica.

5 Las organizaciones también inciden a favor de leyes que protegen los derechos humanos, incluidos los derechos sexuales y/o los derechos reproductivos - especialmente en beneficio de las y los miembros de la sociedad más marginados o vulnerables. En prácticamente cada país hay grupos que trabajan a favor de esas leyes.

Algunos ejemplos de ese tipo de leyes (que en algunos entornos también están bajo una jurisdicción religiosa) incluyen: - proteger el derecho de cada ciudadano a votar;

- prohibir el trabajo infantil y proteger la seguridad de las y los trabajadores;

- proteger a las y los miembros de la comunidad contra la brutalidad policiaca;

- penalizar los "crímenes de odio" (amenazas y violencia con base en la identidad de una persona);

- posibilitar el acceso físico al espacio público, incluso para personas con discapacidades;

- prohibir la violencia contra las mujeres (fuera y dentro del matrimonio);

- garantizar los derechos de las mujeres dentro del matrimonio;

- garantizar los derechos de herencia de las viudas;

- prohibir el matrimonio infantil;

- penalizar la trata de personas con fines de explotación sexual; y

- proteger los derechos de todas las personas a formar una unión civil, matrimonio o familia, ya sea con alguien del mismo sexo o del sexo opuesto. 
6 Algunas organizaciones trabajan para tener un impacto en los derechos humanos a nivel global.

Por ejemplo:

- Buscan expandir la lista de derechos humanos reconocida por las Naciones Unidas.

- Usan internet con el fin de formular peticiones globales para responder a abusos en contra de los derechos humanos.

7 Las y los adolescentes pueden ayudar y, de hecho, ayudan a crear el cambio - incluido el cambio en sus propias vidas.

La gente joven en todo el mundo puede responder de muchas maneras a los asuntos que les preocupan. Por ejemplo:

- Están educando a otras personas en sus familias y comunidades.

- Están ayudando a promover las políticas y prácticas que consideran justas.

- Están ayudando a planificar e implementar programas.

- Están alentando a sus amistades para que se unan a campañas. 


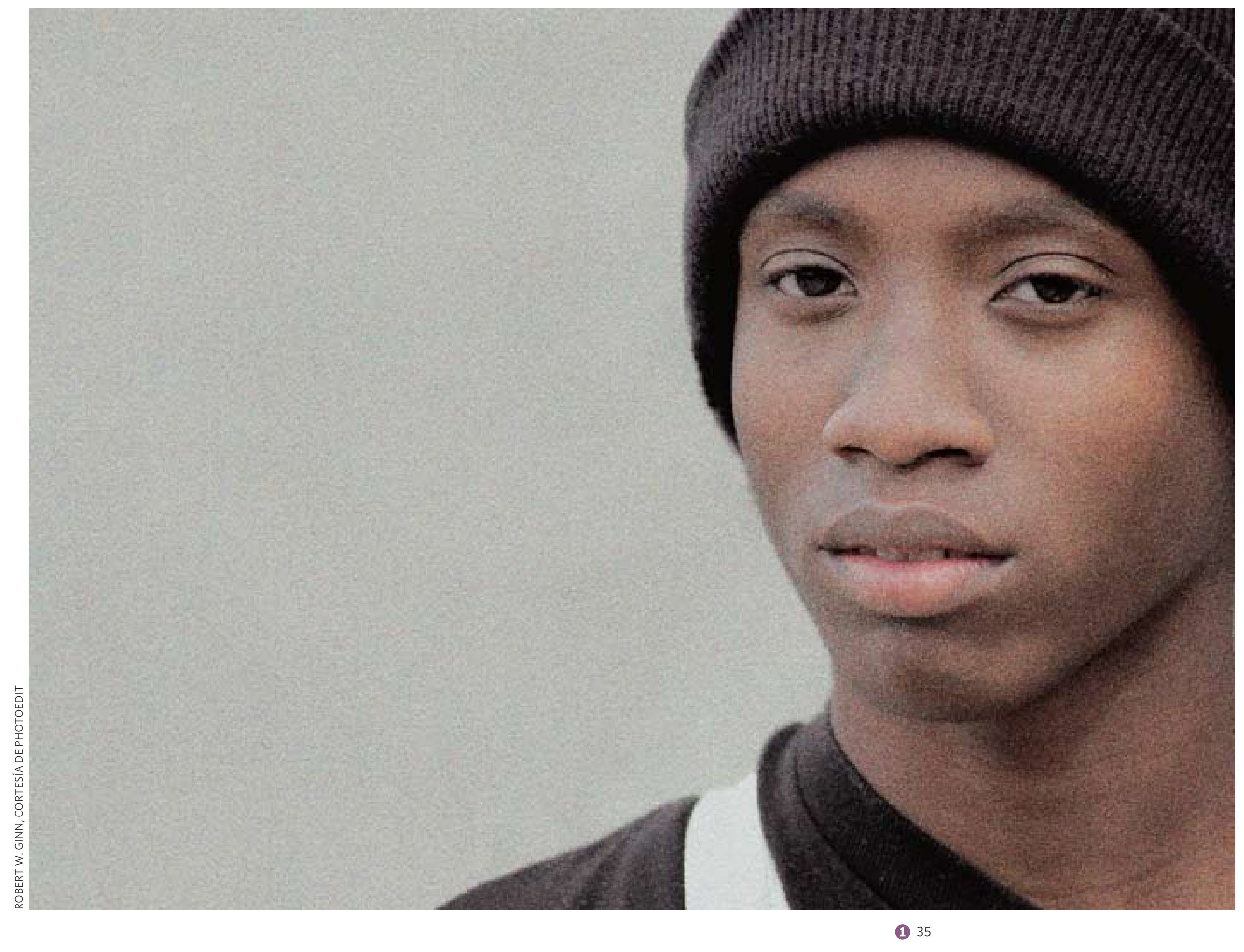




\title{
conceptos básicos sobre personas y comunidades, valores y derechos
}

\author{
Las siguientes explicaciones breves pretenden ayudar a las y los usuarios con la \\ aclaración de términos importantes relacionados con la sociedad y los derechos \\ humanos. Estos términos se utilizan en todo este documento. Las y los educadores de \\ todo el mundo aportan su creatividad y sensibilidad a la tarea de adaptar estos conceptos \\ en sus propios contextos culturales y políticos.
}

Comunidades: son grupos de personas que pueden compartir ciertas características. Éstas incluyen las creencias, necesidades, el ambiente en donde viven o trabajan y su identidad. Existen varios tipos de comunidades. Como miembros de una comunidad, las personas tienen tanto derechos como responsabilidades por la forma en que se tratan entre sí.

Derechos humanos: se refiere a las protecciones básicas y derechos que corresponden a cada ser humano. Estos derechos son inalienables. Esto es, nadie puede quitárselos a otra persona. Una lista parcial incluye el derecho a: la alimentación y cobijo; educación; servicios de salud; participación y expresión cívica; trato igual ante la ley; y trato con respeto y dignidad. La capacidad de las personas para ejercer plenamente sus derechos humanos afecta virtualmente cada uno de los aspectos de sus vidas.

Los gobiernos tienen la responsabilidad de respetar, proteger y cumplir con estos derechos. La mayoría de los gobiernos han respaldado los acuerdos internacionales para tal efecto. Las personas, a su vez, tienen el derecho de exigir que los gobiernos mantengan vigentes estas obligaciones y responsabilidades. Las personas tienen también el derecho de asegurar que los gobiernos cumplan con estas obligaciones.

Discriminación: es el trato injusto o desigual que se da a las personas basándose en su apariencia, comportamiento o identidad (supuesta o real).

Estereotipos: son generalizaciones y suposiciones sobre las personas y comunidades, con base en su identidad o comportamiento. Por ejemplo, la idea de que las niñas son débiles en matemáticas es un estereotipo. Tales generalizaciones con frecuencias son inexactas; o pueden ser totalmente inventadas. Los estereotipos pueden conducir al estigma, la discriminación y otros resultados dañinos. 
Estigma: se refiere a una seria desaprobación social con base en las características personales.

Puede también surgir cuando las convicciones o acciones de una persona no cumplen con las normas sociales. Por ejemplo, en algunos lugares las personas enfrentan el estigma debido a su peso corporal, comportamiento sexual, religión o estado de salud.

Género: se refiere a diferencias en los roles sociales que las sociedades y las familias esperan de los hombres y las mujeres. El género no es lo mismo que las diferencias biológicas por sexo. Con frecuencia, las personas experimentan diferencias en el ejercicio del poder dentro de sus familias y sociedades debido a su género.

Identidad: es la forma en que las personas piensan de sí mismas, o se describen a sí mismas ante otras personas. La manera en que otras personas perciben la apariencia o comportamiento de alguien no coincide necesariamente con la percepción que la persona tiene de su propia identidad. Típicamente, las personas tienen más de un aspecto que define su identidad. Por ejemplo, una persona puede identificarse como niño, como hindú y también como estudiante. La identidad puede basarse en la pertenencia a una comunidad. La forma en que las personas se identifican a sí mismas puede cambiar con el tiempo. ("Identidad" también puede referirse al reconocimiento formal de la existencia de una persona por parte del Estado, como por el hecho de tener un nombre, un registro de nacimiento y una nacionalidad.)

Normas sociales: son las expectativas sobre cómo deben actuar o pensar las personas en una comunidad. Al crecer, las personas llegan a pensar que las normas prevalecientes son "naturales" o "normales". De hecho, las normas varían de lugar a lugar y a través del tiempo. Las normas prevalecientes con frecuencia presionan a las personas para que cumplan con las expectativas sociales. Esas normas influyen en las actitudes y comportamiento de las personas. Las personas que actúan o piensan de formas que son diferentes a la norma, en vez de ser consideradas independientes pueden ser consideradas inferiores.

Valores: se refiere al conjunto de creencias o convicciones que gobiernan lo que las personas consideran como correcto y equivocado. Los valores varían entre los individuos, las familias y las culturas. Algunos valores, sin embargo, son aceptados virtualmente y en forma universal como característicos del comportamiento ético del ser humano. 


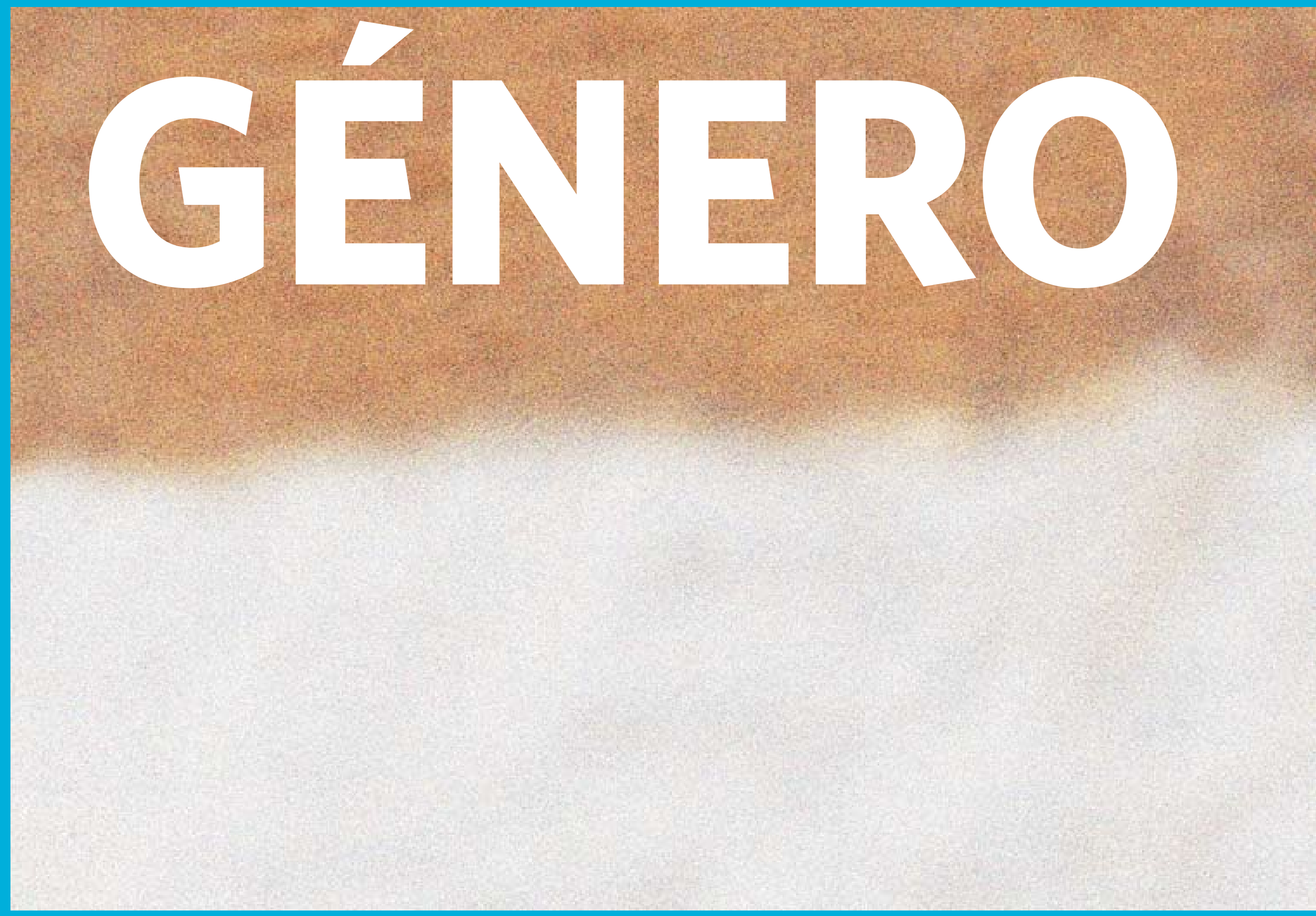




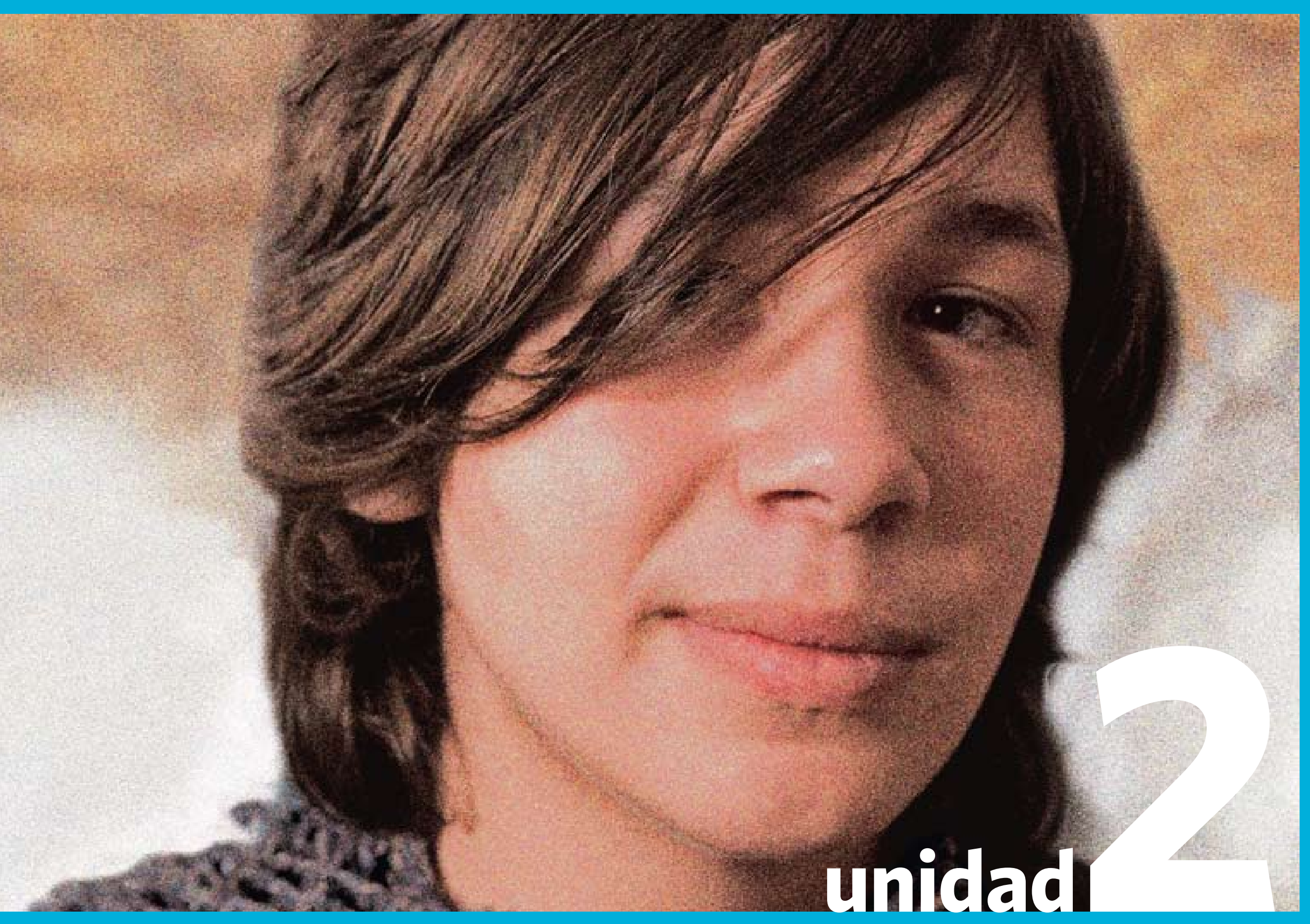




\section{visión general}

Las normas de género afectan el bienestar de toda persona, incluida su salud sexual y el riesgo de contraer el VIH. La mayoría de los países han identificado el logro de la igualdad de género como un imperativo moral y como un factor clave para responder al SIDA y fortalecer a las familias y las sociedades. En todo el mundo, las normas y los roles de género están cambiando rápidamente. Es vital aumentar el nivel de conciencia de las y los adolescentes sobre temas de género, debido a que las intervenciones durante este período de formación pueden alterar dramáticamente los resultados posteriores en la vida.

Esta unidad define el género y explora la forma en que las normas de género afectan las vidas y la salud tanto de los niños como de las niñas. Sugiere maneras de posibilitar que la gente joven imagine la clase de personas que quieren ser, la clase de relaciones que esperan formar y el tipo de sociedad que consideran justa y feliz. 


\section{GÉNERO}

Haga énfasis en que el término "género" se refiere tanto a los niños como a las niñas.

Haga uso de ejemplos concretos sobre aspectos de género - tomados ya sea del libro de ACTIVIDADES, o de su propio entorno. Los ejemplos que son reconocibles pueden ayudar a que las y los estudiantes comprendan que el género es más que una idea abstracta.

Continúe poniendo énfasis en que tanto los niños como las niñas pueden beneficiarse de unas normas y acuerdos de género menos rígidos. Recuerde que muchos estudiantes ya han elegido adoptar roles menos convencionales y que se sienten bien respecto a sí mismos.

Dentro de una cultura determinada, así como entre culturas, la dinámica de género toma diferentes formas. Sea sensible a la naturaleza (y variabilidad) de la dinámica de género en su entorno cultural local.

Comience con ejemplos sobre la desigualdad y la discriminación que las y los estudiantes reconozcan (como el racismo o el estigma asociado con el VIH y el SIDA). Estos ejemplos les ayudarán a comprender la desigualdad y la discriminación en su relación con el género.

El tema de roles de género puede generar reacciones a la defensiva o de hostilidad. Planifique formas de suavizar discusiones potenciales y mantener un diálogo abierto y respetuoso.

Recuerde que muchos estudiantes han experimentado violencia. Hablar acerca de este tema requiere de sensibilidad y planificación. Establezca un ambiente seguro de aprendizaje. Proporcione un apoyo apropiado y referencias según sea necesario.

Apoye los esfuerzos de las y los estudiantes para procesar sus sentimientos. Cuestionar nuestras propias actitudes, o las de la gente que nos rodea puede ser difícil o confuso. Pero esto es posible y puede ser una experiencia empoderadora.

Fomente un ambiente seguro para la discusión abierta. Considere la posibilidad de separar a las niñas de los niños para algunas actividades. Posteriormente, puede reunirlos de nuevo para un análisis compartido.

Para definiciones de términos básicos, ver el glosario al final de la Unidad 2. Las hojas informativas al final de este libro proporcionan detalles adicionales en temas selectos. 


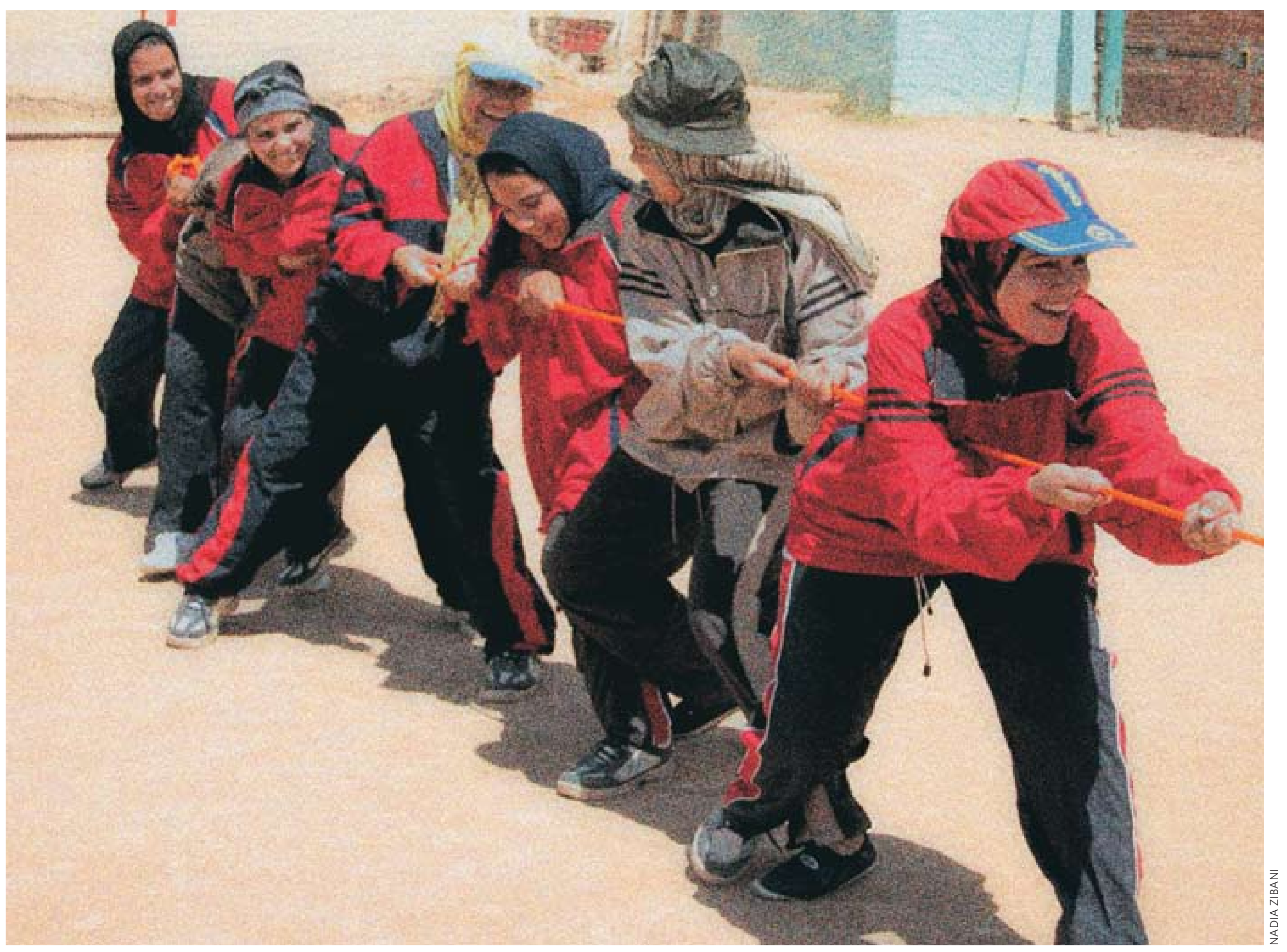




\section{GÉNERO}

El material en esta unidad prepara a las y los estudiantes para:

\section{Objetivos cognoscitivos}

Distinguir entre sexo y género.

Dar un ejemplo de cómo los roles de género masculino y femenino están cambiando. Describir los pasos que la gente sigue para promover cambios positivos en los roles de género.

Analizar en conjunto la forma en que la desigualdad de género afecta las oportunidades, incluidos el acceso a la educación, el espacio público, los servicios de salud, la participación cívica y el empleo.

Dar tres ejemplos de cómo las niñas y los niños aprenden sus roles de género a partir de sus familias y comunidades.

Analizar en conjunto la forma en que las instituciones (el matrimonio, la familia, los medios, la religión, las escuelas) refuerzan las normas de género.

Analizar en conjunto la forma en que las normas de género perpetúan el matrimonio infantil, la mutilación genital femenina y la violencia (incluida la violencia sexual).

Explicar la forma en que los roles convencionales de género pueden aumentar la probabilidad de que las mujeres y las niñas enfrenten el VIH u otras infecciones de transmisión sexual y el embarazo no planeado.

\section{Objetivos afectivos}

Comprender que las normas de género pueden minar el bienestar tanto de los niños como de las niñas. Analizar en conjunto los roles de género que han cuestionado o que les gustaría cuestionar. Aclarar en conjunto sus opiniones acerca de la violencia de pareja íntima y la coerción sexual. Describir cómo la socialización de género puede afectar los sentimientos de seguridad y autoestima.

\section{Objetivos basados en destrezas}

Demostrar destrezas de pensamiento analítico y crítico en la explicación de sus ideas. 


\section{definición de género}

\section{PUNTOS PARA REFLEXIÓN}

¿Qué mensajes reciben las niñas en el hogar acerca de cómo deben comportarse? ¿En la escuela? ¿De líderes religiosos? ¿De los medios? ¿Reciben los niños los mismos mensajes?

¿Cuáles son los empleos típicamente "femeninos" que los hombres podrían hacer?

¿Cuáles son los empleos típicamente "masculinos" que las mujeres podrían hacer?

¿Tienen las mujeres las mismas oportunidades que los hombres en su sociedad? ¿En todas las sociedades? ¿Enfrentan los hombres algunas presiones simplemente por el hecho de ser hombres?

¿Tienen las mujeres en su sociedad exactamente el mismo rol que tenían hace cien años? ¿Cuáles son algunas diferencias?

¿Qué piensan actualmente los niños sobre la igualdad de género, en comparación con las actitudes que tenían sus padres o abuelos?
- 1 En cada sociedad, las normas de género y los roles de género influyen en las vidas de las personas, incluso en sus vidas sexuales.

○ 2 Los roles de género se aprenden. No son innatos o "naturales". De hecho, casi todo lo que pueden hacer los hombres, lo pueden hacer también las mujeres. Y casi todo lo que las mujeres pueden hacer, los hombres también lo pueden hacer.

3 Dentro de una cultura o sociedad, las personas tienen diferentes actitudes acerca de los roles de género y la igualdad de género.

○ 4 Las convicciones acerca del género también varían de una cultura (o sociedad) a otra.

๑ 5 Los roles de género cambian con el tiempo y, en muchos entornos, las personas especialmente la gente joven - están adoptando una mayor igualdad de género. 
Ver el glosario al final de esta unidad para una introducción sencilla a estos conceptos.

6 Una mayor igualdad de género y roles de género más flexibles dan a cada persona más oportunidades de desarrollarse a plena capacidad como ser humano. En contraste, los roles de género restrictivos pueden limitar esas oportunidades.

7 A pesar de la desigualdad de género (u otras barreras similares), todos los días millones de personas buscan hacer realidad sus sueños. Si bien no toda la gente goza de las mismas oportunidades de manera automática, muchas personas cumplen sus sueños luchando por una oportunidad justa y trabajando arduamente para aprovechar las oportunidades que se les presentan.

8 El logro de la igualdad de género es un objetivo clave alrededor del mundo. ${ }^{1}$

- La igualdad entre hombres y mujeres es un asunto de derechos humanos.

- Lograr la igualdad de género es una parte clave de la respuesta al VIH y SIDA, para terminar con el matrimonio infantil, para reducir los embarazos no deseados y para hacer más seguro el embarazo.

- La igualdad de género fomenta el crecimiento de comunidades y sociedades saludables y prósperas.

- La Organización de las Naciones Unidas ha identificado a la igualdad de género como uno de los ocho objetivos de desarrollo que las naciones deben perseguir.

- Millones de personas están promoviendo activamente la igualdad de género - en las familias, escuelas, centros de trabajo, comunidades y países. [Ver la última sección en esta unidad; ver también la Unidad 8.]

VER EL LIBRO DE ACTIVIDADES Actividad 5

mapeo de palabras relacionadas con hombre y mujer

Las y los estudiantes trabajan en grupos para realizar un mapeo de palabras relacionadas sobre lo que significa ser "hombre" o "mujer" y para conversar acerca de dónde provienen sus ideas. 


\section{identidad de género}

1 Al nacer, se identifica a los recién nacidos como hombres o mujeres con base en sus órganos sexuales. En muchos entornos, las personas indican el sexo de un bebé mediante el uso de nombres específicos, joyería, vestido y otros elementos.

2 El término que se usa para algunos bebés, cuyos genitales no son claramente masculinos o femeninos, es intersexual. Algunos niños y niñas (independientemente si son intersexuales o no) llegan a tener una sensación de ambigüedad respecto a su identidad de género, o claramente se identifican con el sexo opuesto al que fueron criados.

3 Casi todos los niños y niñas se comportan en formas que no corresponden a los estereotipos asociados con su género.

Dos ejemplos son:

- Muchas niñas gozan practicando deportes, destacan en matemáticas y tienen sueños de dirigir a su país — y aún así, se sienten como niñas.

- Muchos niños gozan al desarrollar relaciones interpersonales estrechas, al participar en la creación artística y al sentirse libres de las constantes presiones para tener éxito y ser valientes — pero siguen sintiéndose niños. 


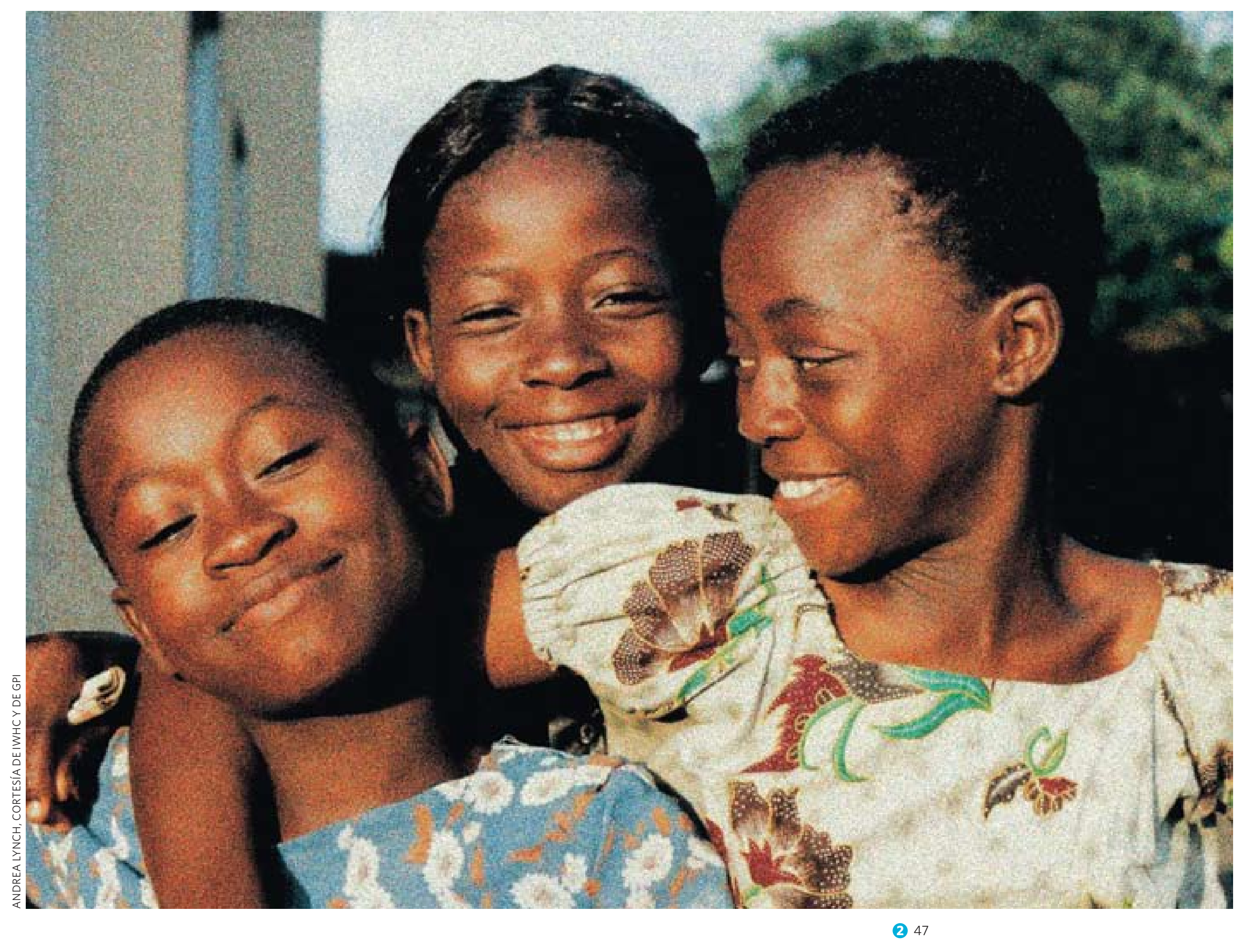




\section{las normas y roles de género se consolidan durante la infancia y la adolescencia}

1 Los roles de género esperados son aparentes en muchos aspectos de la vida familiar.

Por ejemplo:

- Los miembros de la familia modelan las normas de género en sus propios roles y comportamientos. Dependiendo de la cultura y la familia, los roles masculinos y femeninos podrían ser similares o distintos.

- Típicamente, los hombres y las mujeres tienen diferentes responsabilidades y roles en relación con el cuidado de infantes, niñas y niños. De esta forma, desde su infancia, las y los niños comienzan a observar y asimilar las normas de género.

\section{Algunas familias tratan a niñas y niños de igual manera.}

Por ejemplo, se alienta tanto a los hijos como a las hijas a:

- buscar el éxito en la esfera pública;

- expresar sentimientos de vulnerabilidad; $y$

- compartir las tareas del hogar en forma igualitaria.

3 Sin embargo, muchas familias no tratan a niñas y niños de igual manera.

Por ejemplo, aún en la primera infancia:

- En entornos con escasez de alimentos, las niñas infantes pueden no ser alimentadas tan bien como sus hermanos.

- Con frecuencia se viste a las niñas de manera diferente; y a los niños y se les da juguetes diferentes.

- En particular, cuando los recursos son escasos, las familias suelen trabajar más duro para asegurar la educación de sus hijos hombres [ver sección sobre Género y Educación más adelante.]

- En algunas sociedades, las mujeres son vistas como propiedad de sus esposos. En esos lugares, las familias pueden tener menos probabilidad de invertir recursos escasos para alimentar y educar a las niñas, de quienes se supone crecerán y abandonarán a la familia.

- Aunque muchos niños tienen que realizar labores del hogar, hay la tendencia de dar a las niñas más responsabilidades domésticas y a dejarles menos tiempo libre que a sus hermanos.

- Los niños pueden ser desanimados de llorar o de expresar sus sentimientos o vulnerabilidad.

- Las niñas pueden ser desanimadas de afirmarse a sí mismas o de participar en deportes "rudos".

4 Las personas - incluidos los padres - con frecuencia refuerzan las expectativas sobre el género a través del lenguaje. 
5 Conforme la gente joven se aproxima a su adolescencia, siente más presión para ajustarse a roles de género determinados culturalmente.

\section{A pesar de las diferencias culturales, muchos niños adolescentes comparten experiencias} similares.

En todo el mundo, los niños varones gozan de una mayor independencia y libertad fuera de casa que las niñas; y tienen más oportunidades de participar en la vida pública. También, los niños están sujetos a presión para probar su heterosexualidad y hombría; por ejemplo, para:

- ser valientes y enérgicos;

- tener dinero y prepararse con el fin de convertirse en proveedores;

- suprimir ciertas emociones (por ejemplo, la vulnerabilidad y la ternura) o los comportamientos que pueden parecer "femeninos";

- emplear la violencia física (contra personas conocidas o desconocidas);

- tener un buen desempeño como atleta y tener un cuerpo musculoso;

- evitar la búsqueda de servicios de salud; o, incluso, negar que están enfermos o que han sido lastimados;

- "probar" su heterosexualidad, por ejemplo, teniendo relaciones heterosexuales o incluso convirtiéndose en padres;

- tomar riesgos teniendo relaciones sexuales no seguras (aumentando con ello su riesgo de contraer la infección por VIH); y

- tomar riesgos físicos (incluido el uso de drogas, el alcohol o manejando un vehículo).

Los niños pueden enfrentar el acoso o la brutalidad policiaca. Esto es especialmente cierto para los niños de grupos

minoritarios o marginados, o los que viven en vecindarios de bajos ingresos. Algunos niños pueden enfrentar severas golpizas por faltas relativamente menores a la conducta.

\section{A pesar de las diferencias culturales, muchas niñas adolescentes comparten experiencias} similares.

En todo el mundo, las niñas tienden a gozar de mayores oportunidades que los niños para desarrollar y practicar habilidades de relación de persona a persona. Las niñas también están sujetas a presiones para cumplir con normas de feminidad; por ejemplo, para: - ser proveedoras de atención;

- ser dóciles y sumisas con los hombres, minimizar su inteligencia, subvalorar u ocultar sus opiniones e ideas;

- aceptar que sus derechos estén limitados;

- aceptar un estricto monitoreo de su forma de vestir, amistades y de todos sus movimientos;

- cuidarse de no herir los sentimientos de las personas;

- evitar tener relaciones sexuales antes del matrimonio; incluso si desean tenerlas; y

- ceder a tener relaciones sexuales no deseadas. [Ver sección sobre Coerción Sexual en esta unidad; también ver Unidad 3, páginas 106-107.] 
8 Los roles de género rígidos también afectan la forma en que las personas se tratan entre sí y contribuyen al suicidio, violencia y muchos otros problemas sociales.

- Las personas que no se ajustan a las normas de género dominantes, pueden ser objeto de burlas, o ser aisladas o amenazadas.

- Las personas que pueden estar especialmente sujetas a ese tipo de estigma incluyen: personas que se les percibe como homosexuales, niños en los que se percibe algunos rasgos femeninos, mujeres con parejas sexuales múltiples, o personas que adoptan una identidad de género diferente de aquella con la que fueron criados (personas transgénero).

9 A pesar de las normas sociales, millones de personas jóvenes están determinadas a "ser ellas mismas" y a realizar más de su potencial como seres humanos. Ellas creen en una mayor igualdad de género y en la diversidad.

- Muchas personas jóvenes pueden resistir presiones para ajustarse a una imagen corporal idealizada.

- Muchas niñas tienen confianza en sí mismas y en su propio poder. Ellas saben que pueden luchar por oportunidades para trabajar arduamente, tener logros y perseguir sus sueños.

- Muchos niños tienen confianza para resistir las presiones convencionales para probar su hombría.

- Muchos niños sienten la libertad para expresar una gama de emociones, incluida la vulnerabilidad y la ternura. Más adelante en la vida, su libertad puede también aumentar su capacidad y satisfacción como padres.

- Muchas personas jóvenes celebran la diversidad y las diferencias.

10 Las normas de género están cambiando en todo el mundo. La gente joven que trabaja por la igualdad y la justicia está ayudando a que ese cambio ocurra.

[Ver en esta Unidad la sección titulada Género: Nuestras propias decisiones y acciones.] 


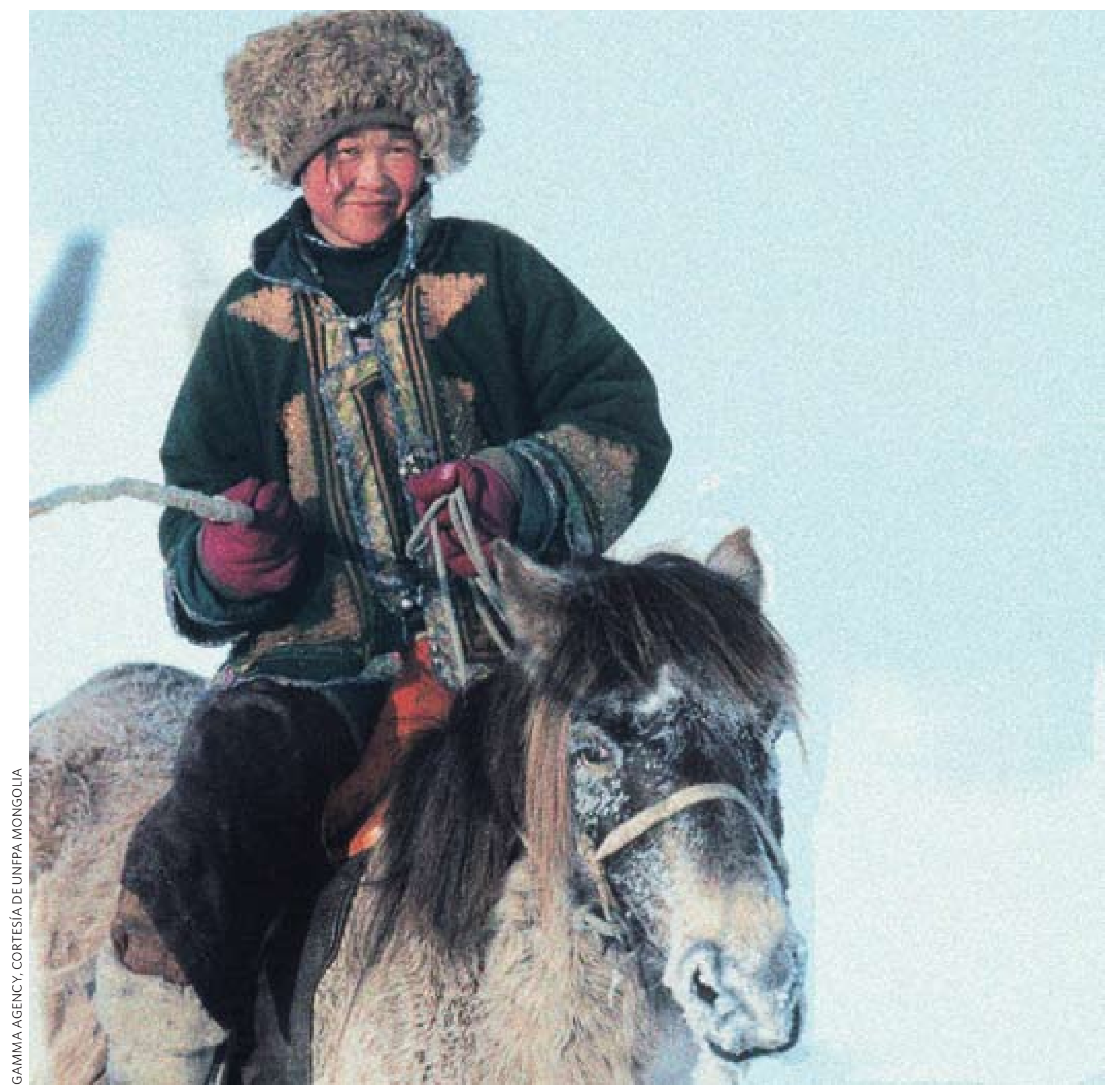

VER EL LIBRO DE ACTIVIDADES Actividad 6

viaje por la memoria: aprendizaje sobre el género en la niñez

Las y los estudiantes comparten algún recuerdo de algún momento en su vida cuando fueron tratados de cierta forma debido a su sexo; y recuerdan sus sentimientos acerca de esas experiencias.

VER EL LIBRO DE ACTIVIDADES Actividad 7

imágenes de paternidad

Las y los estudiantes escriben acerca de su padre o algún hombre que les haya cuidado. Posteriormente, analizan en grupo la forma en que los roles de género limitan el rol de los hombres como cuidadores. 


\section{género y educación}

Toda persona -sin distinción de tipo alguno, como raza, sexo, idioma, religión, origen social u otra condición - tiene derecho a la educación (Artículo 26.1 . Declaración Universal de los Derechos Humanos [UDHR], 1948; Artículo 13.1, Pacto Internacional sobre Derechos Económicos, Sociales y Culturales [ICESCR] 1966; Artículo 10, Convención Internacional sobre la Eliminación de Todas las Formas de Discriminación en Contra de las Mujeres [CEDAW], 1979; Artículo 8.1, Convención sobre los Derechos del Niño [CRC], 1989).

1 El acceso a la educación es un derecho universal. Sin embargo, en muchos países, los niños tienen mayor probabilidad que sus hermanas de asistir a la escuela (en todos los niveles) y de ir a escuelas de mayor calidad.

Los obstáculos para que las niñas asistan a la escuela pueden incluir:

- el menor valor que se asigna al desarrollo de las capacidades de las niñas;

- las prioridades económicas de la familia;

- los temores de que viajar a la escuela pondrá en peligro la seguridad (y reputación) de las niñas;

- las preocupaciones acerca del acoso o violencia sexual por parte de maestros o estudiantes hombres;

- las expectativas de que las niñas deben ayudar con el trabajo doméstico;

- lo inadecuado de los recursos para que las niñas manejen su menstruación;

- las normas locales sobre el matrimonio y maternidad tempranos; y

- la falta de oportunidades iguales en la fuerza laboral para las mujeres preparadas.

2 El acceso a la educación es un factor crítico para lograr la igualdad de género. Aún así, en muchos lugares, los ambientes escolares tienden a reforzar la desigualdad en los roles de género y las opciones relacionadas.

VER EL LIBRO DE ACTIVIDADES Actividad 8

proyecto de investigación: el género en el ambiente escolar

Las y los estudiantes conducen una investigación sobre el rol del género en la escuela e informan sobre sus hallazgos.
Por ejemplo:

- Típicamente, los niños exigen más del tiempo y atención de sus maestros que las niñas. Ellos tienen también más probabilidad de asumir roles de liderazgo.

- El personal escolar puede ser tolerante con el lenguaje degradante y las "bromas" sobre las mujeres o las minorías.

- Las estudiantes, especialmente las niñas, pueden ser acosadas sexualmente (por estudiantes y/o maestros varones).

- Las y los estudiantes que no se ajustan a las normas prevalecientes de género pueden ser marginados socialmente.

- Las niñas pueden ser desalentadas de cursar materias que son tradicionalmente temas masculinos (en algunos entornos las ciencias y las matemáticas).

- Los niños pueden ser alejados de actividades que se perciben como más femeninas (como algunos deportes y las artes).

- Muchos niños se ven presionados para tener éxito en las actividades atléticas o para demostrar su masculinidad mediante el uso de lenguaje despectivo y alardear en el salón de clase.

- Algunos programas de educación sexual y sobre VIH pueden en realidad reforzar los estereotipos de género negativos.

- En algunos entornos, las estudiantes mujeres no pueden asistir a la escuela si están embarazadas. 
3 Algunos ambientes escolares son, en realidad, inseguros.

- En algunas escuelas, las niñas enfrentan el riesgo de relaciones sexuales forzadas, a veces por parte de personas adultas.

- La gente joven que se percibe como homosexual y transgénero con frecuencia enfrenta violencia e intimidación.

- Las pandillas pueden representar un riesgo para toda la gente joven, especialmente para los niños.

- Las y los maestros pueden también enfrentar estos riesgos.

\section{Con frecuencia, también los materiales educativos refuerzan la desigualdad en los roles} de género y las opciones relacionadas.

\section{Muchas personas en todo el mundo están trabajando para promover la igualdad de género} en la educación y para expandir el acceso a la escuela para toda la gente.

- Las personas jóvenes están insistiendo en el derecho de las niñas a permanecer en la escuela por tantos períodos escolares como lo hacen sus hermanos.

- Algunos gobiernos proporcionan estipendios a las familias a cambio de mantener a sus hijas en la escuela.

- Las y los educadores están revisando los libros de texto y los currículos para hacerlos más equitativos en materia de género.

- Algunas comunidades patrocinan programas para evitar que los niños se unan a pandillas, usen drogas y que se involucren en otros comportamientos que frecuentemente les llevan a abandonar la escuela.

\section{Más gente joven en todo el mundo va a la escuela y permanece en ella por más tiempo} que antes.

- A través de la historia, el aprendizaje ha sido uno de los mayores placeres de la humanidad.

- La educación es crucial para proporcionar las habilidades que la gente joven necesita para encontrar un trabajo satisfactorio y para enfrentar los retos de un mundo cambiante y globalizado.

- Toda la gente joven tiene derecho a la educación.

\section{PUNTOS PARA REFLEXIÓN}

¿Es responsabilidad de la escuela el proporcionar un ambiente seguro para la totalidad de estudiantes y maestros? ¿Se siente seguro todo el mundo en nuestra escuela?

Las y los niños que van a la escuela aprenden sobre las personas que han hecho contribuciones a la sociedad por ejemplo, a la historia, a la ciencia, al arte y a la literatura. ¿Cuánto aprenden de las contribuciones de las mujeres? ¿Qué hay de las contribuciones de las minorías raciales o étnicas?

¿Qué es lo que sus lecciones o libros escolares incluyen acerca de las contribuciones de toda la gente a la sociedad? Si usted trabaja con libros escolares, considere tanto el texto, como las imágenes y fotografías.

¿Qué actitudes asimilan las y los niños que van a la escuela si un currículo excluye la contribución de ciertos grupos de personas? 


\section{estereotipos de género en los medios}

1 Tanto las historias infantiles como los medios ejercen una influencia poderosa y de gran alcance en las normas de género y las expectativas de la gente joven. Tales medios incluyen radio, televisión, filmes, periódicos, revistas, internet y la publicidad.

2 Las imágenes y mensajes en los medios pueden promover y exponer a la gente a valores de igualdad, respeto y dignidad - o a valores de falta de respeto y desigualdad.

3 Las historias infantiles y los medios con frecuencia refuerzan la desigualdad de género y la falta de respeto.

Algunas de las formas en que los medios hacen esto incluyen:

- representar roles masculinos y femeninos estereotipados (por ejemplo, presentando a los hombres como héroes y a las mujeres como víctimas), así como estereotipos de grupos raciales y étnicos; de personas en relaciones del mismo sexo; y otros;

- representar y exaltar tipos corporales idealizados;

- representar a las mujeres y niñas en formas estrechamente relacionadas con el sexo; y

- reservar para los hombres las posiciones más importantes y visibles en los programas de noticias, en los filmes y en la televisión.

\section{PUNTOS PARA REFLEXIÓN}

¿Cómo presentan los medios locales a los hombres y las mujeres?

¿Qué mensajes trasmiten los cuentos de hadas a las y los niños acerca de la masculinidad y la feminidad?

¿Qué medios alternativos, si es que existen, dan voz a las personas que han estado ignoradas, presentadas en forma negativa o, de alguna otra forma, estereotipadas en los principales medios?
4 La gente joven en todo el mundo está creando sus propios medios y contando sus propias historias de vida. Muchos grupos promueven la conciencia pública sobre los mensajes en los principales medios de comunicación. 


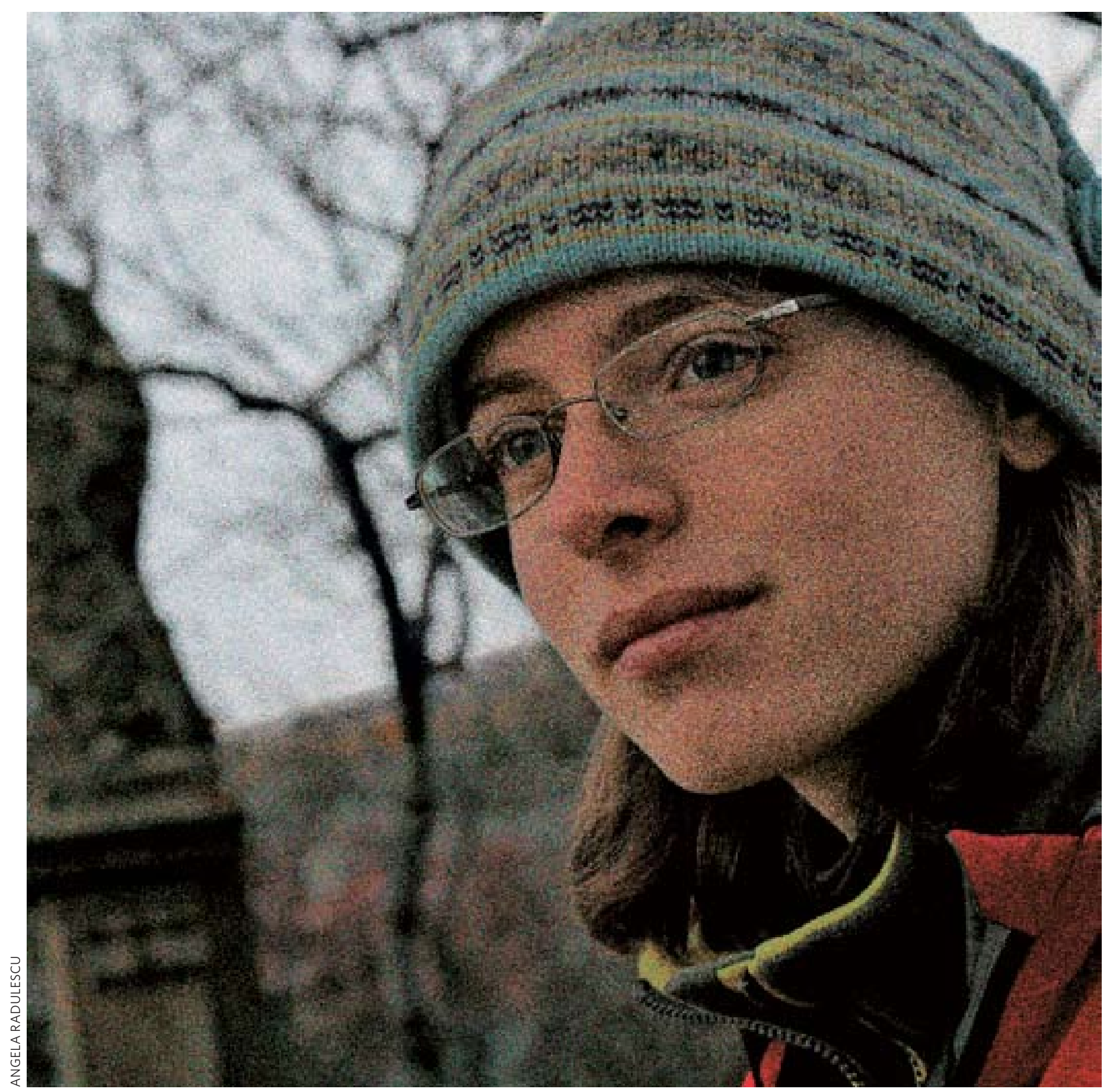

VER EL LIBRO DE ACTIVIDADES Actividad 9

venta de estereotipos: análisis de la publicidad

Las y los estudiantes hacen un collage de imágenes femeninas y masculinas tomadas de medios publicitarios y analizan el mensaje de género en esas imágenes. Crean anuncios que se apartan de los estereotipos. 


\section{cómo afecta el género la movilidad, la conexión social y los espacios públicos seguros}

Toda persona tiene derecho a circular libremente y a elegir su residencia en el territorio de un Estado (Artículo 13.1, UDHR, 1948).

Toda persona tiene derecho a tomar parte libremente en la vida cultural de la comunidad (Artículo 27.1, UDHR, 1948; Artículo 15.1, ICESCR, 1966).

1 Es importante tener la capacidad de moverse libremente y con seguridad en la comunidad. Esto ayuda a que las personas tengan acceso a información, servicios y empleos, así como a formar redes de apoyo social. El poder conectarse socialmente fuera del hogar es agradable y ayuda a que las personas expandan sus horizontes. El estar aisladas en su hogar, conduce a algunas personas a sentirse deprimidas.

2 En muchos entornos, las normas de género restringen la capacidad de las mujeres a desplazarse libremente en sus comunidades.

Por ejemplo:

- A las niñas adolescentes generalmente se les concede mucha menos libertad que a los niños de dejar su hogar y desplazarse dentro de sus comunidades. Como resultado, muchas veces las niñas no puede hacer deporte, visitar a sus amistades, tener acceso a servicios, o prepararse para participar plenamente en la sociedad.

- En algunos entornos, las mujeres que salen solas se arriesgan a ser etiquetadas como "malas" o "de moral dudosa". Ellas pueden enfrentarse al acoso o violencia sexual.

- En algunos entornos, las mujeres adultas son forzadas al aislamiento en sus hogares. Ellas tienen que ir acompañadas a destinos como la casa de alguna amistad, clínica de salud o tienda. 
3 En algunos contextos, los espacios públicos son inseguros y conllevan peligros reales.

Por ejemplo:

- En muchas comunidades de bajos ingresos y de minorías, los niños enfrentan la violencia y el acoso o brutalidad policiaca, así como el encarcelamiento.

- Algunas comunidades tienen altos niveles de actividad de pandillas y falta de opciones para obtener empleos decentes o educación avanzada. En tales sitios, los niños pueden ser involucrados como miembros de pandillas o utilizados para el tráfico de drogas.

- Los niños son involucrados desproporcionadamente en la guerra u otras formas de combate.

- Típicamente, las mujeres y las niñas que viven en campos de refugiados o las personas desplazadas internamente, zonas de trabajo de nuevos migrantes, o en otras comunidades inestables, enfrentan un alto riesgo de violencia, incluida la violencia sexual.

- En muchos lugares, las personas percibidas como homosexuales o transgénero sufren asaltos físicos que pueden poner en riesgo sus vidas.

4 A pesar de los tabúes sociales, muchas personas jóvenes se rehúsan a ser confinadas al aislamiento. En donde les es posible, crean espacios seguros para reunirse. Algunos ejemplos de personas que han formado ese tipo de espacios seguros pueden incluir a las niñas casadas; las trabajadoras domésticas; las personas que se sienten atraídas por otras del mismo sexo; las y los jóvenes transgénero; las niñas que desean una oportunidad para practicar deportes; y las personas que se dedican al trabajo sexual.

\footnotetext{
VER EL LIBRO DE ACTIVIDADES Actividad 10

el espacio de género

Las y los estudiantes dibujan mapas de sus comunidades, mostrando cuáles espacios son seguros ya accesibles para personas de tal o cual sexo. Analizan la forma en que la participación en la vida cívica se ve afectada por los roles de género.
} 


\section{cómo afecta el género la participación cívica y política}

VER EL LIBRO DE ACTIVIDADES Actividad 11

mujeres en acción:

proyecto de hacer un libro

Las y los estudiantes crean libros infantiles sobre una mujer líder.
Toda persona tiene derecho a participar en el gobierno de su país, incluido el derecho a votar, a ser elegible para elección y tener acceso en condiciones de igualdad a las funciones públicas (Artículo 21, UDHR, 1948; Artículo 25, Pacto Internacional sobre Derechos Civiles y Políticos (ICCPR, 1966); Artículo 7, CEDAW, 1979).

1 Aunque toda persona tiene derecho de participar en la vida pública, no todas las personas pueden ejercer este derecho en condiciones de igualdad.

2 Con frecuencia, las y los miembros de algunos grupos enfrentan obstáculos para participar en sociedad. Esto puede incluir a las mujeres y las niñas, las personas que viven en condiciones de pobreza, las personas con discapacidades, las personas que viven abiertamente en relaciones del mismo sexo, las personas ancianas y las minorías étnicas y raciales.

Por ejemplo:

- En algunos lugares, las mujeres no pueden votar y rara vez desempeñan posiciones de liderazgo público. Puede suceder que ellas tengan menor acceso a los programas gubernamentales y menor capacidad para participar en sociedad.

- Aún en entornos en donde las mujeres tienen puestos altos, la mayoría de las mujeres pueden sufrir serias condiciones de desigualdad de género y oportunidades limitadas de participar en sociedad.

3 Aunque aún existe una significativa brecha de género muy extendida en la vida cívica y política; en algunos lugares las mujeres están rompiendo ese tipo de barreras.

- Algunas mujeres se desempeñan como líderes a nivel local, estatal y nacional. En algunos países, los partidos políticos tienen la obligación de nominar a mujeres al menos en un 30 a un 50 por ciento de su planilla electoral.

- Algunas mujeres también dirigen organizaciones no gubernamentales de todo tamaño.

- A pesar de los retos que enfrentan, algunas mujeres líderes fuertes son visibles en la vida comunitaria y pública, en cada una de las regiones del mundo.

- Algunas mujeres se han organizado en grupos efectivos y de gran vitalidad. Estos grupos fomentan el diálogo y promueven el empoderamiento, igualdad y los derechos humanos de las mujeres.

- Muchos hombres están trabajando activamente para aumentar el acceso de las mujeres a la vida cívica y política en condiciones de igualdad.

4 Sueña en grande y trabaja duro. iTú puedes escalar cumbres y hacer diferencias importantes en el mundo! 


\section{género, trabajo y recursos económicos: dentro y fuera de casa}

Toda persona tiene derecho al trabajo, a la libre elección de su trabajo, a condiciones equitativas y satisfactorias de trabajo y a la protección contra el desempleo; y toda persona tiene derecho - sin discriminación alguna - a igual salario por trabajo igual (Artículo 23, UDHR, 1948; Artículos 6, 7, ICESCR, 1966; Artículo 11, CEDAW, 1979).

1 Toda persona - ya sea hombre o mujer - es capaz de criar y cuidar niñas y niños, realizar labores domésticas y trabajar en empleos pagados fuera del hogar.

2 No obstante, en la mayoría de los entornos, las presiones económicas - y las oportunidades (incluido el acceso al dinero en efectivo) - varían según el sexo.

3 Muchas mujeres - y muchos hombres - alrededor del mundo están tratando de expandir el acceso de las mujeres y las niñas a los recursos, así como al control de los mismos.

Están haciendo esto, por ejemplo, a través de:

- políticas que permiten a las mujeres tener propiedades o que promueven la contratación y promoción de las mujeres y de otros grupos deficientemente representados en los centros de trabajo;

- programas de micro-financiamiento y ahorros, que proporcionan dinero en efectivo directamente a las mujeres para que participen en la economía informal, especialmente en lugares en donde ese tipo de recursos se destina principalmente a los hombres;

- esfuerzos de las trabajadoras del sexo para mejorar y controlar sus condiciones de trabajo;

- programas que están dirigidos a mujeres que tienen que permanecer en sus hogares o lugares de reclusión;

- educación y capacitación vocacional que pueden expandir las opciones de las mujeres en los mercados formales e informales de trabajo; $y$

- servicios de guardería infantil de bajo o ningún costo, que permiten a los padres y madres de familia buscar empleos potencialmente mejor remunerados.

4 Todos nos beneficiamos cuando cada persona puede desarrollarse y aplicar sus talentos y cuidados en sus familias, en el trabajo y en la comunidad.

Por ejemplo:

- Ser una madre o un padre comprometido y amoroso puede proporcionar enormes recompensas emocionales tanto a los padres y madres como a sus hijos e hijas.

- Conforme las mujeres se incorporan a la fuerza laboral, los hombres se involucran más en la paternidad.

- El acceso a la educación y al empleo en condiciones de igualdad, permite que la gente joven tenga más opciones de trabajo.

\section{PUNTOS PARA REFLEXIÓN}

¿Cuáles son algunos de los empleos en los que los hombres deben

enfrentar riesgos físicos? ¿Ausencias muy prolongadas de sus familias?

¿Cómo trata la sociedad a un hombre joven que no puede encontrar un trabajo decente?

¿Qué clase de salarios reciben las mujeres en comparación con los hombres?

¿Usualmente, de qué forma los padres y madres de familia que tienen empleo comparten las responsabilidades domésticas y del cuidado de los hijos? 


\section{género y matrimonio}

Los hombres y las mujeres, a partir de la edad núbil, tienen derecho a casarse y fundar una familia, y disfrutarán de iguales derechos en cuanto al matrimonio, durante el matrimonio y en caso de disolución del matrimonio (Artículo 16.1, UDHR, 1948; Artículo 16.1, CEDAW, 1979).

Sólo mediante libre y pleno consentimiento de los futuros esposos podrá contraerse el matrimonio (Artículo 16.2, UDHR, 1948; Artículo 16.1, CEDAW, 1979). No tendrán efecto jurídico los esponsales y el matrimonio de niños... (Artículo 16.2, CEDAW, 1979).

1 Muchas personas forman relaciones de largo plazo (incluso de toda la vida) en las que viven juntas. Éstas son llamadas relaciones domésticas. Las personas tienen diferentes razones para formar ese tipo de relaciones.

Por ejemplo:

- Se aman y estar juntas las hace felices;

- Desean compañía;

- Necesitan seguridad económica;

- Desean tener hijos; y

- Sus comunidades o familias esperan que así lo hagan.

2 Algunas personas que viven en relaciones domésticas comprometidas a largo plazo contraen matrimonio formal bajo las leyes de su estado o religión. Las personas tienen diferentes razones para contraer matrimonio.

Por ejemplo:

- Desean honrar o legitimar una relación íntima en el contexto de los valores ya sea de ambos miembros de la pareja, de sus respectivas familias, comunidad o sociedad.

- Desean honrar o legitimar la maternidad en el contexto de los valores de la persona, de sus respectivas familias, comunidad, religión o sociedad.

- Necesitan de prestaciones que pueden no ser otorgadas a personas que no están casadas o a las que no se les permite casarse, como son los servicios de salud y pensión de viudez, así como de la aprobación social de las relaciones sexuales.

- Cumplen con los deseos y planes de sus padres. (En algunos entornos, los padres típicamente hacen arreglos para los matrimonios de sus hijos. Esto lo hacen para asegurar parejas apropiadas para sus hijos. Pueden tener preocupación por la reputación de alguno de sus hijos. Pueden también casar a una hija con la finalidad de aliviar las presiones económicas de la familia). El matrimonio infantil (matrimonio antes de los 18 años de edad) es una grave violación de los derechos humanos, pero continúa siendo común en algunas partes del mundo. 
3 Algunas personas que tienen relaciones domésticas comprometidas a largo plazo no contraen matrimonio formal. Las personas tienen diferentes razones para no contraer matrimonio.

Por ejemplo:

- Decisión personal: Una pareja puede sentirse cómoda al renunciar a la aprobación formal por parte del estado o por una institución religiosa.

- Se les niega el derecho a casarse. Una familia o sociedad puede prohibir el matrimonio de personas del mismo sexo o el matrimonio entre personas de diferentes razas, religiones o castas sociales.

- La pareja puede carecer de los recursos económicos (ingreso, dote o precio por la novia) que necesitan tener antes de poder casarse.

\section{El matrimonio es una compleja y arraigada institución social.}

- El matrimonio puede proporcionar muchos beneficios y apoyos mutuos. En muchos matrimonios, ambos miembros de la pareja trabajan para apoyarse mutuamente y para apoyar los derechos de uno y otro.

- Con frecuencia, el matrimonio también refleja y refuerza las normas de género, algunas veces de maneras que son injustas, discriminatorias y dañinas.

\section{Ciertos movimientos sociales promueven condiciones de mayor igualdad y dignidad} dentro del matrimonio.

Estos movimientos incluyen:

- movimientos para legalizar el matrimonio entre personas del mismo sexo;

- campañas en contra de la dote y el matrimonio infantil; y

- reformas legales que garanticen una herencia justa, que permitan a ambas partes iniciar un divorcio y que penalicen la violencia marital, incluida la violación.

\section{PUNTOS PARA REFLEXIÓN}

¿Qué tan válido es el "consentimiento" de una niña de 16 años para contraer matrimonio?

¿Las expectativas de una niña o un niño de llegar virgen al matrimonio son las mismas?

¿Cómo siente una mujer ser considerada como propiedad de su marido y su familia? ¿De qué forma las tradiciones de la dote o precio por la novia afectan los derechos humanos de las mujeres?

¿Debe el matrimonio dar al esposo el derecho de exigir relaciones sexuales a su pareja, independientemente de los deseos de ella? ¿En qué consiste la violación marital? (La violación usualmente se define como un asalto que involucra relaciones sexuales forzadas o que tienen lugar sin consentimiento.) 


\section{género y religión}

Los gobiernos deben tomar medidas para que la tradición y la religión, así como sus expresiones, no sean base para la discriminación en contra de las niñas (Párrafos 24 y 276.d, Plataforma de Acción de la FWCW, 1995).

1 Las religiones mantienen una amplia gama de perspectivas respecto al género y la sexualidad. Estas perspectivas pueden cambiar con el tiempo. Las actitudes también varían dentro de cualquier religión.

2 Muchas personas encuentran que no siempre están de acuerdo con su líder religioso en temas relacionados con el género y la sexualidad. No obstante, las perspectivas religiosas influyen en las creencias y comportamientos de muchas personas.

3 La religión o los líderes religiosos pueden influir en las normas de género (y las sexuales) de varias maneras. [Ver también, la Unidad 3, página 88.]

- Algunas tradiciones religiosas son más igualitarias (orientadas a la igualdad) con respecto al género. Otras son mas patriarcales (basadas en un sistema de poder masculino).

- Las religiones varían en el grado en el que influyen o tratan de influir en las normas de género, la sexualidad y la fecundidad. Los textos religiosos pueden también ser interpretados de manera selectiva para justificar u oponerse a ciertas prácticas.

- Algunos líderes religiosos apoyan la difusión de información y el acceso a la anticoncepción, el uso del condón, el aborto y la educación sexual. Otros se oponen a ese tipo de acceso.

- Algunas religiones apoyan la igualdad de derechos para todas las personas independientemente de su identidad sexual. (Esto incluye el permiso para ser ordenadas como líderes de su religión). Otras religiones se oponen a la homosexualidad y a los derechos de las personas homosexuales.

- Algunas religiones o líderes religiosos refuerzan un doble estándar respecto a la sexualidad. Ellos hacen esto al bendecir tanto la virginidad de la mujer y la fidelidad dentro del matrimonio, a la vez que condonan la poliginia (la práctica en la que los hombres tienen múltiples esposas). Sin embargo, otras religiones o líderes no lo hacen.

- Algunas religiones y líderes religiosos apoyan la igualdad de género en el divorcio, la herencia y la vida en comunidad. En otros entornos, las leyes o prácticas religiosas pueden restringir el movimiento de las mujeres, o prohibir derechos en condiciones de igualdad (o prohibir totalmente) los derechos en términos del divorcio, la herencia u otros asuntos familiares. Las leyes religiosas en ocasiones entran en conflicto con las leyes civiles. 
4 Frecuentemente se niega a las mujeres la oportunidad de participar en condiciones de igualdad con los hombres en la vida religiosa.

- Típicamente, las mujeres asumen muchas de las actividades de apoyo comunitario para las instituciones religiosas, pero tienen oportunidades limitadas para llegar a posiciones de liderazgo dentro de esas instituciones.

- En algunas instituciones religiosas, no se permite a las mujeres orar junto con los hombres.

5 Algunas personas, alrededor del mundo, incluidos muchos líderes religiosos, están trabajando para promover los valores de los derechos humanos y la igualdad de género dentro de sus comunidades.

- Ejemplos de organizaciones que realizan trabajo de este tipo incluyen a Mujeres que Viven bajo la Ley Musulmana y Católicas por el Derecho a Decidir. 


\section{género y autonomía corporal}

VER EL LIBRO DE ACTIVIDADES Actividad 12

alteración de los cuerpos

Las y los estudiantes identifican la apariencia idealizada para los hombres y las mujeres en su cultura y examinan las prácticas en las que la gente se involucra para hacer que su apariencia se ajuste a este ideal.
Todo individuo tiene derecho a la vida, a la libertad y a la seguridad de su persona (Artículo 3, UDHR, 1948; Artículos 6.1 y 9.1, ICCPR, 1966), Nadie será sometido a... tratos crueles, inhumanos o degradantes (Artículo 5, UDHR, 1948; Artículo 7, ICCPR, 1966; Artículo 37.a, CRC, 1989). Los Estados Partes adoptarán todas las medidas eficaces y apropiadas posibles para abolir las prácticas tradicionales que sean perjudiciales para la salud de los niños (Artículo 24.3, CRC, 1989).

Sólo mediante libre y pleno consentimiento de los futuros esposos podrá contraerse el matrimonio (Artículo 16.2, UDHR, 1948; Artículo 16.1, CEDAW, 1979). No tendrán efecto jurídico los esponsales y el matrimonio de niños... (Artículo 16.2. CEDAW, 1979).

1 Todas las personas merecemos tener un control básico sobre nuestros propios cuerpos. Esto incluye el vivir libres de violencia y abuso sexual, así como de presión para involucrarnos en actos violentos en contra de otras personas. El control sobre el propio cuerpo también se refiere a decidir si tener o no relaciones sexuales y cuándo tenerlas; si embarazarse o no y cuándo hacerlo; si continuar o no con un embarazo; e, incluso, si alterar o no la propia apariencia y cómo hacerlo.

2 Tal control promueve la confianza, seguridad, salud, placer y la oportunidad de explorar la propia identidad. Desafortunadamente, tanto los niños como las niñas pueden sentir que otras personas están ejerciendo poder y control físico o sexual sobre ellos. Sentir que usted ha perdido el control sobre su propio cuerpo puede resultar muy perturbador, incluso traumático.

3 El control de nuestros cuerpos se ve influido por nuestros valores familiares, por nuestras instituciones y normas sociales y religiosas, así como por leyes formales. 


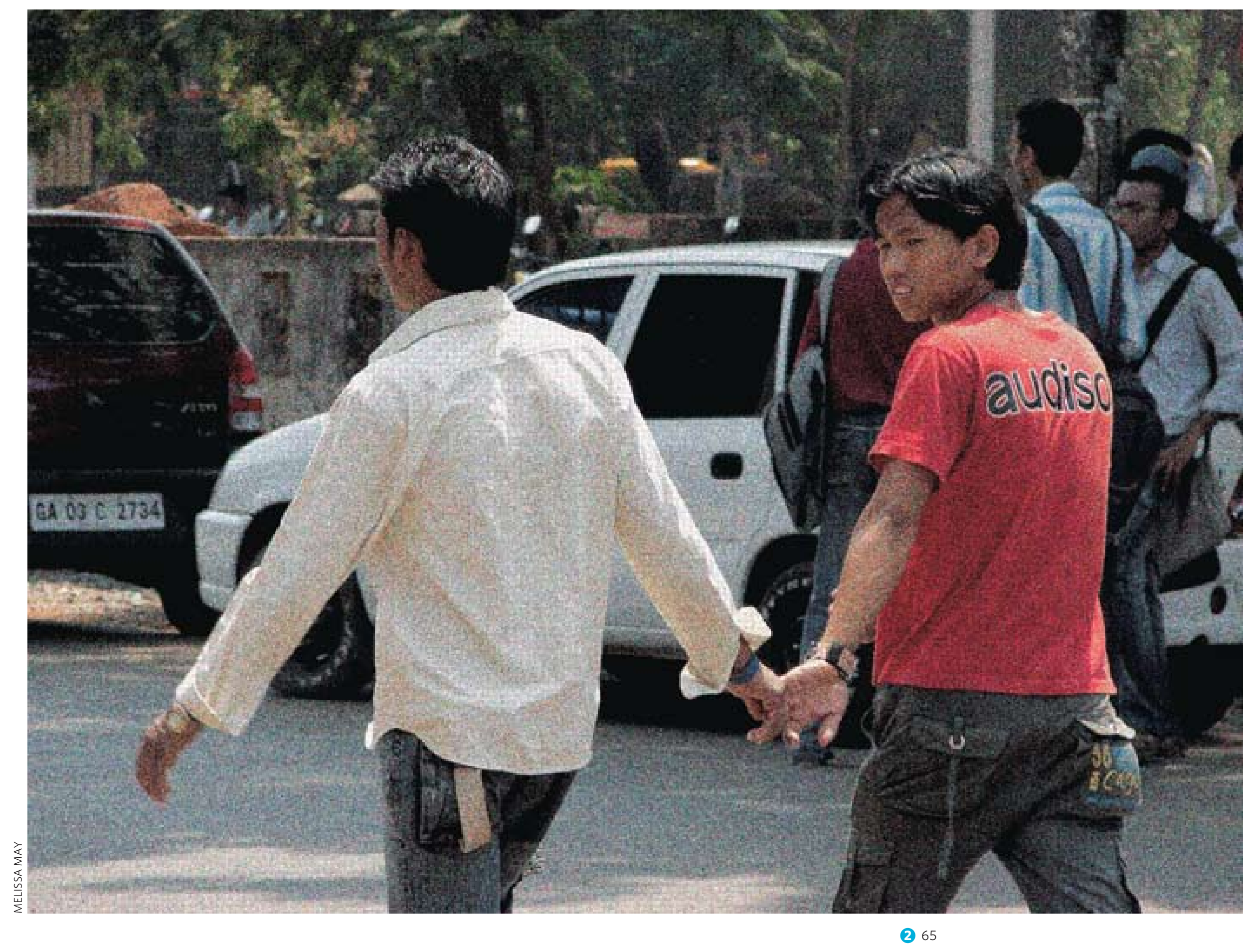




\section{PUNTOS PARA REFLEXIÓN}

Aparte de las prácticas coercitivas como la mutilación genital femenina, millones de mujeres y niñas

se someten voluntariamente a procedimientos médicos riesgosos (o participan en prácticas que ponen en riesgo su salud) con el fin de lograr una apariencia que se ajuste a un ideal cultural. ¿Cuáles son algunos de estos procedimientos y prácticas? ¿Cómo determina la sociedad las características ideales de la mujer atractiva?

¿Cuáles son las razones por las que algunas personas usan cremas para aclarar la piel? ¿De dónde proviene la idea de que un color de piel es más atractivo que otro?

¿Por qué (en algunos entornos) algunas niñas y mujeres restringen severamente su ingestión de alimentos; $y$, por qué (en algunos entornos) algunas ponen agentes secantes dentro de sus vaginas?
4 Casi en cualquier parte, las mujeres experimentan una regulación y un control más estrictos sobre sus cuerpos que los hombres.

Por ejemplo, las niñas tienen más probabilidad de:

- ser criadas con la expectativa de tener poco control sobre sus propios cuerpos;

- experimentar límites para su expresión sexual. Muchas todavía sufren de violación y acoso sexual (como insinuaciones poco gratas, petición de favores sexuales, u otras conductas verbales o físicas desagradables de naturaleza sexual);

- estar limitadas en sus movimientos o su vestido (como no poder desplazarse por la comunidad) y tener menores oportunidades de practicar deportes.

\section{5 En algunos lugares, las niñas están sujetas a un control extremo sobre sus cuerpos.}

Ejemplos de esto incluyen:

- la mutilación genital [ver la hoja informativa correspondiente al final de este libro]; y

- el matrimonio temprano o forzado.

\section{Los hombres también son presionados para involucrarse en prácticas potencialmente} dañinas.

Por ejemplo:

- Algunos hombres jóvenes consumen medicamentos peligrosos para aumentar su volumen muscular.

- En algunos entornos, los niños son sometidos a ritos tradicionales, a veces peligrosos, para ganar su estatus de adultez. Estos niños pueden ser sometidos a ritos tales como rituales de supervivencia en la selva, la circuncisión realizada bajo condiciones inseguras, o la iniciación sexual obligatoria en un burdel. 
7 Con frecuencia, algunas familias, comunidades, religiones y gobiernos regulan y castigan los comportamientos (incluido el comportamiento sexual) que no se ajusta a las expectativas relacionadas con los roles de género.

[Ver la Unidad 3 sobre Sexualidad.]

Tales castigos pueden variar en severidad, por ejemplo, la gente puede:

- aplicar a las niñas sexualmente activas nombres despectivos (como "puta"), mientras que no existe un equivalente despectivo para los niños heterosexuales;

- aprobar severos castigos legales y sociales para las mujeres que se involucran en actividades sexuales extramaritales, a la vez que condonan - e incluso premian — comportamientos similares en los hombres;

- penalizar y abusar de las trabajadoras del sexo, mientras que quienes pagan por sexo generalmente no sufren consecuencias legales; y

- penalizar la homosexualidad.

8 Muchos padres y niños alrededor del mundo defienden el derecho de la gente joven a la autonomía y la dignidad. Muchas organizaciones están también trabajando hacia esta meta a través de la educación de las comunidades y promoviendo cambios legales.

9 El cuerpo de cada persona le pertenece a ella misma. Nadie tiene derecho de abusar, lesionar o violar el cuerpo de alguien más en modo alguno. 


\section{género y violencia}

Todo individuo tiene derecho a la vida, a la libertad y a la seguridad de su persona (Artículo 3, UDHR, 1948; Artículos 6.1 y 9.1, ICCPR, 1966). Nadie será sometido a ... tratos crueles, inhumanos o degradantes (Artículo 5, UDHR, 1948; Artículo 7, ICCPR, 1966; Artículo 37.a, CRC, 1989).

1 Toda persona desea sentirse libre de violencia. La mayoría también nos sentimos mejor con nosotros mismos si no cometemos actos de violencia en contra de otras personas.

2 Las tasas de violencia varían dramáticamente en función del lugar y a través del tiempo.

3 Las personas cometen muchos tipos de violencia, incluida la fuerza física, amenazas, intimidación y abuso psicológico. Tales actos de violencia pueden ser realizados por - o a nombre de - personas, grupos, instituciones o el estado.

4 Los hombres tienen más probabilidades que las mujeres de cometer actos de violencia y de ser víctimas de la violencia.

- Muchos hombres jóvenes son motivados socialmente (o presionados) a actuar en forma violenta.

- Los hombres jóvenes son especialmente vulnerables a convertirse en víctimas de la violencia fuera del hogar — en la guerra y conflicto civil, en presiones y en pandillas.

- Con frecuencia, las mujeres son víctimas de violencia interpersonal, muchas veces en su propio hogar.

- Las personas de quienes se percibe que no se ajustan a las normas convencionales de género, pueden ser también víctimas de violencia interpersonal.

5 La violencia contra las mujeres y las niñas, o contra las personas que no se ajustan a las normas dominantes de género, se llama violencia basada en género.

- Las mujeres son especialmente vulnerables a la violencia cometida por personas que ellas conocen, incluidas sus parejas masculinas íntimas.

- Tal tipo de violencia puede ser de naturaleza sexual, como el manoseo no deseado o las relaciones sexuales forzadas. [Ver sección sobre Coerción Sexual y Violencia más adelante.]

- Ese tipo de violencia varía en severidad y puede incluir golpes, quemaduras o asesinato.

- Algunas personas enfrentan la violencia porque se les percibe (correctamente o no) como homosexuales o transgénero. Algunas veces se hace referencia a la violencia que se basa en la identidad de una persona como "crimen de odio".

- Toda forma de violencia basada en género es una violación de los derechos humanos. 


\section{PUNTOS PARA REFLEXIÓN}

Los hombres jóvenes que creen en la igualdad de género tienen menor probabilidad de ser violentos contra sus parejas femeninas. De manera similar, las mujeres jóvenes que creen en la igualdad de género tienen menor probabilidad de involucrarse con parejas masculinas que son violentas. ¿Cómo podría explicarse esto?

Considere si la violencia hacia una persona homosexual es un signo de confianza o falta de confianza por parte de quien agrede.

¿Qué consecuencias a largo plazo para la salud podrían resultar de la violencia basada en género?

\section{Además de ser una violación a los derechos humanos, la violencia contra las mujeres es} también un problema de salud pública de proporciones epidémicas.

- La incidencia de violencia basada en género varía dramáticamente en respuesta a diferentes circunstancias históricas y contextos sociales.

- La violencia contra las mujeres también está asociada al consumo de alcohol o ciertas drogas por parte de los hombres.

- Ese tipo de violencia también puede conducir a problemas de salud a corto o largo plazo. Puede también conducir a problemas de salud mental como la depresión y el aislamiento. La violencia basada en género también está asociada con tasas más altas de VIH y otras ITS.

8 Muchos hombres, mujeres y gente joven están trabajando a nivel local, nacional e internacional para reducir la violencia interpersonal, incluidas todas las formas de violencia basada en género. Tales actividades incluyen: reformas legales, grupos de vigilancia comunitaria, campañas educativas y esfuerzos para cambiar las normas prevalecientes. 


\section{la coerción sexual es una forma de violencia basada en el género}

Ver unidad 3, páginas 106-107:

Consentimiento sexual y coerción.
Toda persona tiene el derecho de vivir libre de toda forma de violencia sexual y coerción (Párrafo 96, Plataforma de Acción de la Cuarta Conferencia Mundial sobre la Mujer [FWCW, 1995]).

1 La coerción sexual ocurre cuando alguien fuerza (o intenta forzar) a otra persona para que participe en una actividad sexual en contra de su voluntad. La relación sexual es coercitiva cuando una persona percibe que no tiene la libertad de rehusase a tener relaciones sexuales sin que haya graves consecuencias sociales y físicas.

2 La coerción sexual es una forma de violencia. Refleja y refuerza la desigualdad de género.

- Tanto hombres como mujeres pueden ser víctimas de coerción para tener relaciones sexuales no deseadas, aunque es más común que las mujeres sean las víctimas.

- Algunas comunidades o leyes toleran la coerción sexual, en lugar de entender que es un tipo de violencia.

3 Las personas pueden ser víctimas de coerción sexual de diferentes maneras, incluidas la manipulación emocional, el engaño, la fuerza física o amenazas, la insistencia verbal, las expectativas culturales, o los incentivos económicos. 


\section{La coerción sexual puede ocurrir en muchos contextos diferentes.}

Por ejemplo:

- La coerción sexual con frecuencia tiene lugar en un entorno o situación que normalmente se considera seguro, como el propio hogar o el de amistades o familiares, la escuela, una institución religiosa, el trabajo, dentro de una relación romántica, o dentro del matrimonio.

- La coerción sexual puede también ocurrir en otras situaciones, por ejemplo, con un extraño, como intercambio material (con parejas o pares mayores, por dinero o regalos materiales), en situaciones de guerra y conflicto, así como dentro de prisiones.

5 La coerción sexual es una violación de los derechos humanos, sin importar el contexto en el que ocurra.

\section{Como otras formas de violencia, la coerción sexual tiene graves consecuencias.}

- Experimentar tal tipo de violencia puede conducir a problemas emocionales, como sentimientos de inseguridad, aislamiento, baja autoestima y depresión severa. También puede conducir a lesiones físicas o incluso la muerte.

- Cuando la relación sexual se realiza bajo coerción, con frecuencia ocurre sin protección. De hecho, el sexo coercitivo se asocia con el aumento en los riesgos tanto de embarazos no planeados como de ITS, incluido el VIH. [Ver Unidad 7.] 


\section{respuesta a la violencia basada en el género}

\section{PUNTOS PARA REFLEXIÓN}

¿Cuáles son algunas de las razones por las que las mujeres permanecen en relaciones en las que son víctimas de abuso físico? ¿Qué papel puede jugar la economía? ¿Debido a temor por la seguridad personal? ¿Preocupaciones por la familia? ¿Preocupaciones acerca de las actitudes de la comunidad? ¿Falta de alternativas? ¿Por no tener conciencia de sus derechos?
- 1 En algunos casos, los hombres pueden dejar de ser abusivos físicamente con sus parejas. En otros casos, las mujeres pueden abandonar a una pareja violenta. Sin embargo, muchas personas permanecen en relaciones violentas. [Ver la Unidad 4.]

2 Es mucho lo que puede hacerse para reducir la incidencia de la violencia basada en género, como el asegurar que las personas sepan que tienen el derecho a vivir libres de violencia, incluida la coerción sexual. [Ver Unidades 3 y 8.]

3 Todas las personas pueden fortalecer su propio compromiso y habilidades para comunicase con sus amistades, miembros de su familia y parejas sexuales acerca de problemas relacionados con la violencia basada en género, incluida la coerción sexual. También pueden alentar a sus amistades a hacer lo mismo.

4 Más y más personas (hombres así como mujeres), organizaciones, comunidades y gobiernos nacionales están trabajando para reducir la violencia.

Ellos hacen esto al:

- enseñar a la gente alternativas sin violencia para la resolución de conflictos, lo que incluye formas para expresar sus sentimientos de manera respetuosa y efectiva.

- apoyar a sobrevivientes de situaciones de violencia basada en género, incluida la provisión de refugio seguro en donde puedan buscar ayuda y seguridad;

- trabajar para cambiar las actitudes que toleran o excusan la violencia o que culpan de ella a la víctima;

- promover normas que respeten la diversidad y las diferencias; y que apoyen a niños y hombres jóvenes a que elijan no adoptar roles masculinos agresivos;

- educar a las personas sobre temas de violencia, incluidas las normas de género que fomentan la violencia, la amplia gama de contextos en los que tiene lugar la violencia, los derechos de todas las personas a vivir libres de violencia y la importancia de la responsabilidad compartida para reducir la violencia; y

- abogar por la aprobación y puesta en vigor de leyes efectivas en contra de la violencia. 


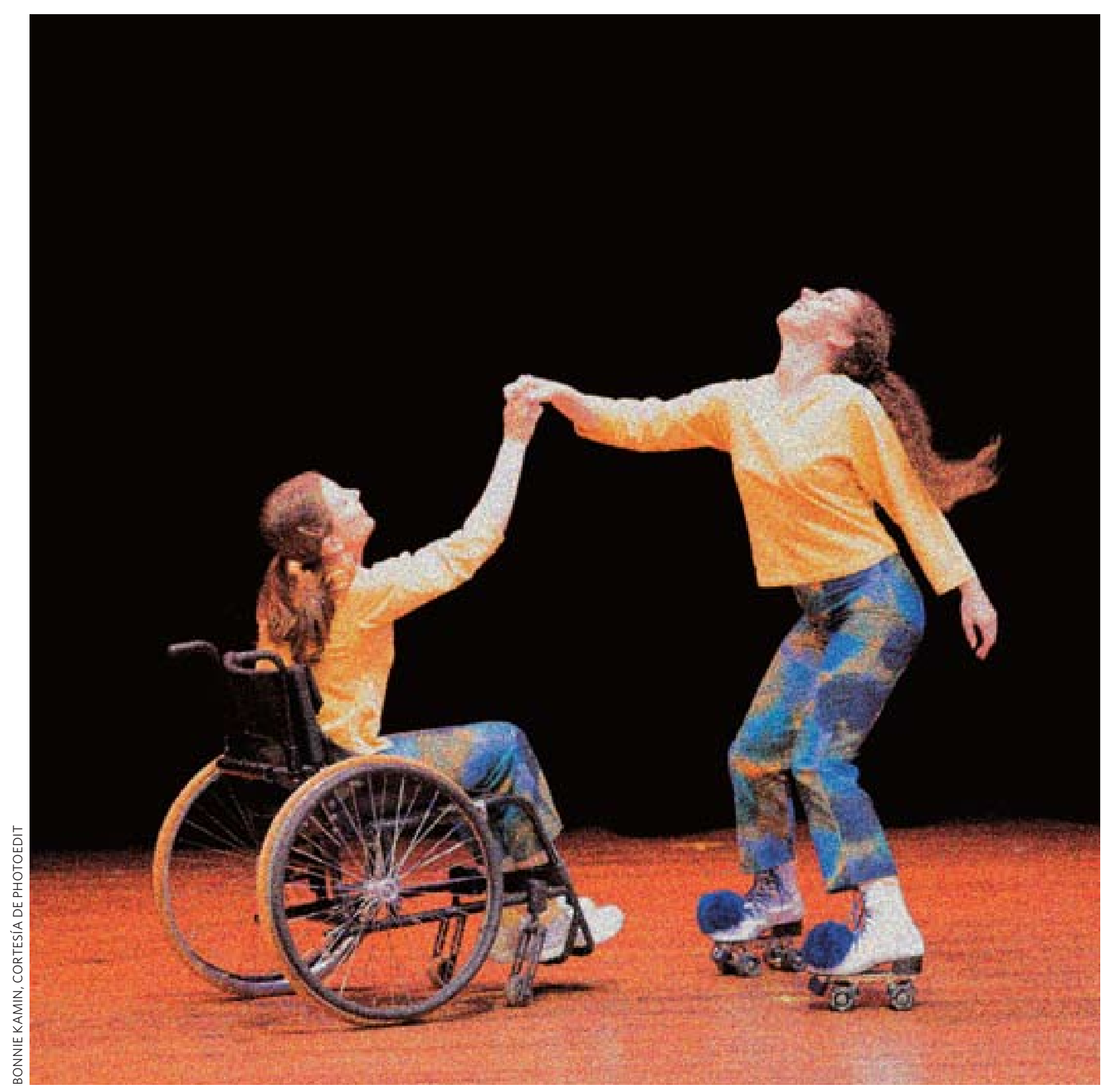

VER EL LIBRO DE ACTIVIDADES Actividad 13

de la violencia al respeto en las relaciones íntimas

Las y los estudiantes desarrollan relatos cortos que exploran los aspectos de respeto y violencia en las relaciones íntimas.

Posteriormente, analizan en grupo la forma de promover el respeto en sus propias relaciones.

VER EL LIBRO DE ACTIVIDADES Actividad 14

acción contra la violencia basada en género

En pequeños grupos, las y los estudiantes desarrollan estrategias para eliminar la violencia contra las mujeres y presentan sus estrategias en formato de noticias por televisión. 


\section{las normas y los roles de género cambian con el tiempo}

1 Las sociedades y culturas están en constante evolución. Las condiciones de los seres humanos cambian, algunas veces para mejorar y otras para empeorar.

Los roles de género también están cambiando.

- Millones de personas en todo el mundo están trabajando activamente en sus familias, escuelas y comunidades para cambiar las normas de género.

2 Los roles de las niñas están cambiando en la mayoría de países del mundo, rápidamente en algunos lugares.

- En muchos lugares, las niñas están logrando lentamente tener acceso a sus derechos.

- En otros pocos, sin embargo, las niñas encuentran sus vidas más y más restringidas.

3 Los roles de los niños también están evolucionando, pero más lentamente.

- Las oportunidades de los niños para analizar y modificar sus identidades y roles continúa siendo limitada.

- Muchos niños sienten presión conflictiva para actuar como "hombres reales", según las definiciones tradicionales. No obstante, también se espera que sean más respetuosos y cuidadosos en sus relaciones con las mujeres.

- Algunas organizaciones de hombres están trabajando a nivel global para eliminar la violencia contra las mujeres.

También están redefiniendo la masculinidad en formas que permitan que niños y hombres tengan vidas más completas como individuos, parejas, padres y miembros de una sociedad justa.

VER EL LIBRO DE ACTIVIDADES Actividad 15

imágenes de roles y normas de género cambiantes

Las y los estudiantes entrevistan a parientes de mayor edad acerca de los roles y normas de género de su juventud. Posteriormente, analizan en grupo la forma en que cambian los roles de género
4 Las actitudes hacia las personas homosexuales y transgénero están cambiando rápidamente en algunos entornos.

5 El nivel de conciencia sobre la violencia sexual está aumentando rápidamente en algunos lugares, pero se necesita más esfuerzos para reducir la prevalencia de ese tipo de violencia. 


\section{género: nuestras propias decisiones y acciones}

Los Estados Partes tomarán las medidas apropiadas para alcanzar la eliminación de los prejuicios y las prácticas consuetudinarias y de cualquier otra índole que estén basados en la idea de la inferioridad de las mujeres (Artículo 5, CEDAW, 1979).

1 La mayoría de nosotros deseamos desarrollar nuestro propio potencial como seres humanos.

2 Sin embargo, nuestra capacidad de desarrollarnos e interactuar plenamente está limitada por las normas y estereotipos que hemos asimilado.

3 Para enfrentar los estereotipos en nuestras propias vidas, tenemos que identificar la forma en que han afectado nuestra identidad, desarrollo personal y opciones de vida.

4 Con el fin de reducir la discriminación basada en género, las personas deben poder reconocerla y actuar al respecto.

5 Reconocer la discriminación basada en género es a veces fácil y a veces difícil. Puede ser obvia: por ejemplo, dar posiciones de liderazgo u otros privilegios a los niños, o hacer un comentario claramente despectivo acerca de alguien que tenga una relación sentimental con otra persona del mismo sexo. O puede ser más sutil y difícil de notar: por ejemplo, ignorar la opinión de alguien debido a su género.

[Ver la Unidad 8 para un mayor detalle de los antecedentes y pautas para actuar al respecto.]

\section{PUNTOS PARA REFLEXIÓN}

El cuestionamiento de los estereotipos de género requiere de un pensamiento honesto y activo sobre nuestras propias experiencias y actitudes.

Considere lo siguiente:

¿Puedo pensar en alguna ocasión en la que fui tratada(o) de cierta manera solamente debido a mi sexo? ¿Cómo me sentí por ello?

¿Qué comportamiento sexual pienso que es aceptable para las mujeres? ¿Para los hombres?

¿Cómo me siento respecto a que las niñas tengan más tareas en el hogar que los niños?

¿Cómo me siento acerca de un niño que es molestado por no actuar de manera suficientemente masculina? 


\section{cambiar el mundo que nos rodea}

1 Alrededor del mundo, millones de personas, incluidos los adolescentes, están trabajando para lograr la igualdad de género y social. Ellos hacen esto para crear una mayor felicidad en sus propias relaciones y vidas, en sus comunidades y en la sociedad en general.

2 La gente joven puede ayudar a promover la igualdad de género y social al:

- tener cuidado de no utilizar lenguaje degradante o decir chistes humillantes;

- manifestarse en contra de la discriminación y violencia basada en género;

- ayudar a una persona que esté siendo marginada - esto puede ayudar a la persona de manera significativa;

- ayudar a lograr que las personas que viven con el VIH o el SIDA sean tratadas de manera equitativa en la comunidad;

- ayudar a reformar leyes que castigan a las personas con base en su identidad sexual; y

- unirse a organizaciones como la Campaña del Listón Blanco (un movimiento global de hombres que trabajan para terminar con la violencia contra las mujeres).

VER EL LIBRO DE ACTIVIDADES

\section{Actividad 16}

hablar con la verdad a las estructuras de poder

Al escribir canciones y poesía,

las y los estudiantes practican la

defensa de la igualdad de género

en las relaciones. 


\section{conceptos básicos sobre género}

Las siguientes breves explicaciones pretenden ayudar a las y los usuarios con la aclaración de términos importantes relacionados con el género. Estos términos se utilizan en todo este documento. Las y los educadores de todo el mundo aportan su creatividad y sensibilidad a la tarea de adaptar estos conceptos en sus propios contextos culturales y políticos.

Género: ideas definidas social o culturalmente sobre la masculinidad (roles, atributos y comportamientos masculinos) y la femineidad (roles, atributos y comportamientos femeninos). El género no es lo mismo que el sexo.

Igualdad de género/desigualdad de género: qué tan iguales (o desiguales) son las oportunidades, cargas y poder social, político y económico de hombres y mujeres. (El término equidad de género tiene un significado similar).

Normas de género: son las expectativas o creencias ampliamente compartidas dentro de una comunidad sobre cómo deben actuar o pensar las personas en su calidad de hombres o mujeres. Las normas de género también se refieren a las opiniones sobre qué tan estricta o consistentemente las personas deben cumplir con uno u otro rol de género.

Patriarcado: sistema de dominación masculina en la sociedad, basado en la creencia de la superioridad de los hombres.

Roles de género: los roles sociales asignados a hombres y mujeres por parte de la sociedad o familia en la que viven. Tales roles incluyen, por ejemplo, la forma en que deben comportarse o que empleos deben tener.

Sexo: el sexo es la diferencia en características biológicas de hombres y mujeres, determinado por los genes de una persona. Por ejemplo, solamente los hombres producen esperma. Solamente las mujeres producen óvulos y pueden embarazarse. [Ver también la definición de intersexual en el glosario de Unidad 3.] Sexo no es lo mismo que género. 
$S=X(U / A / D D / A D$ 


\section{visión general}

La sexualidad puede ser fuente de gran placer y significado en la vida. La actividad sexual es solamente un aspecto de la sexualidad. Las personas experimentan la sexualidad a través de sus sentimientos físicos, emociones, pensamientos, identidad y relaciones. Las normas culturales, las experiencias individuales y las hormonas influyen todas en la forma en que entendemos y experimentamos la sexualidad.

Esta unidad ayuda a la gente joven a comprender lo que es la sexualidad y qué factores afectan la forma en que entendemos y comprendemos la sexualidad. Fomenta en los jóvenes a entender que las relaciones sexuales requieren cierto nivel de madurez y a sentirse más cómodos al abordar temas relacionados con el sexo. Se destaca la importancia del consentimiento, reciprocidad y respeto en las relaciones sexuales. 


\section{SEXUALIDAD}

Las y los educadores pueden ayudar a la gente joven a entender la forma en que la sexualidad se relaciona con el bienestar y la salud.

Hable sobre los aspectos positivos de la sexualidad, pero tenga en cuenta que muchos adolescentes no quieren tener relaciones sexuales, y muchos sencillamenta no están físicamente ni socialmente listos. Aclare que una relación sexual segura y cómoda requiere una cierta madurez y poder para negociar en beneficio propio; destaque especialmente la importancia de la reciprocidad y el respeto.

Plane tiempo para discutir el consentimiento sexual de una manera constructiva. Muchos jóvenes sientan ambivalentes acerca de lo que quieren o confusión sobre los deseos de su pareja. Explora maneras de que puedas asegurar el consentimiento mutuo.

Los valores propios de la o el educador no deben interferir con la enseñanza sobre la sexualidad. Manténgase neutral y evite imponer sus valores personales en las y los estudiantes. Usted puede recurrir a recursos o apoyo para ayudarle a reflexionar en las áreas en las que sienta incomodidad o conflicto en relación con la sexualidad.

Las y los educadores pueden experimentar momentos de apuro al abordar temas de sexualidad. Una cuidadosa preparación ayuda en este sentido.

Ayude a sus estudiantes a comprender y a sentirse cómodos con el uso de los términos correctos para referirse a las partes del cuerpo. Si usted está enseñando en un idioma que carezca de términos científicos para ciertas partes del cuerpo, el utilizar el término más apropiado en forma relajada puede ayudar.

Utilice términos respetuosos y evite el lenguaje hiriente, en particular con respecto a la atracción de personas del mismo sexo, las niñas sexualmente activas y la gente joven que no se ajusta a las normas de género convencionales.

Los temas relacionados con la sexualidad - por ejemplo, el abuso sexual y el SIDA - pueden provocar sentimientos inquietantes o intensos. Las y los estudiantes no deben sentirse presionados a revelar información acerca de sus propias experiencias sexuales. Las y los maestros deben apoyar a sus estudiantes de manera apropiada y respetar su confidencialidad. Deben también estar conscientes, sin embargo, de las obligaciones legales de denuncia relacionadas con la revelación de abuso en contra de una persona menor de edad.

Con el objeto de fomentar un ambiente seguro para el diálogo abierto, considere separar a las niñas de los niños para algunas actividades y reúnalos posteriormente para un análisis compartido.

Algunos temas pueden considerarse controversiales en su entorno local. Realice las consultas necesarias respecto a su currículo.

Para detalles adicionales, consulte a las hojas informativas al final de este libro. 


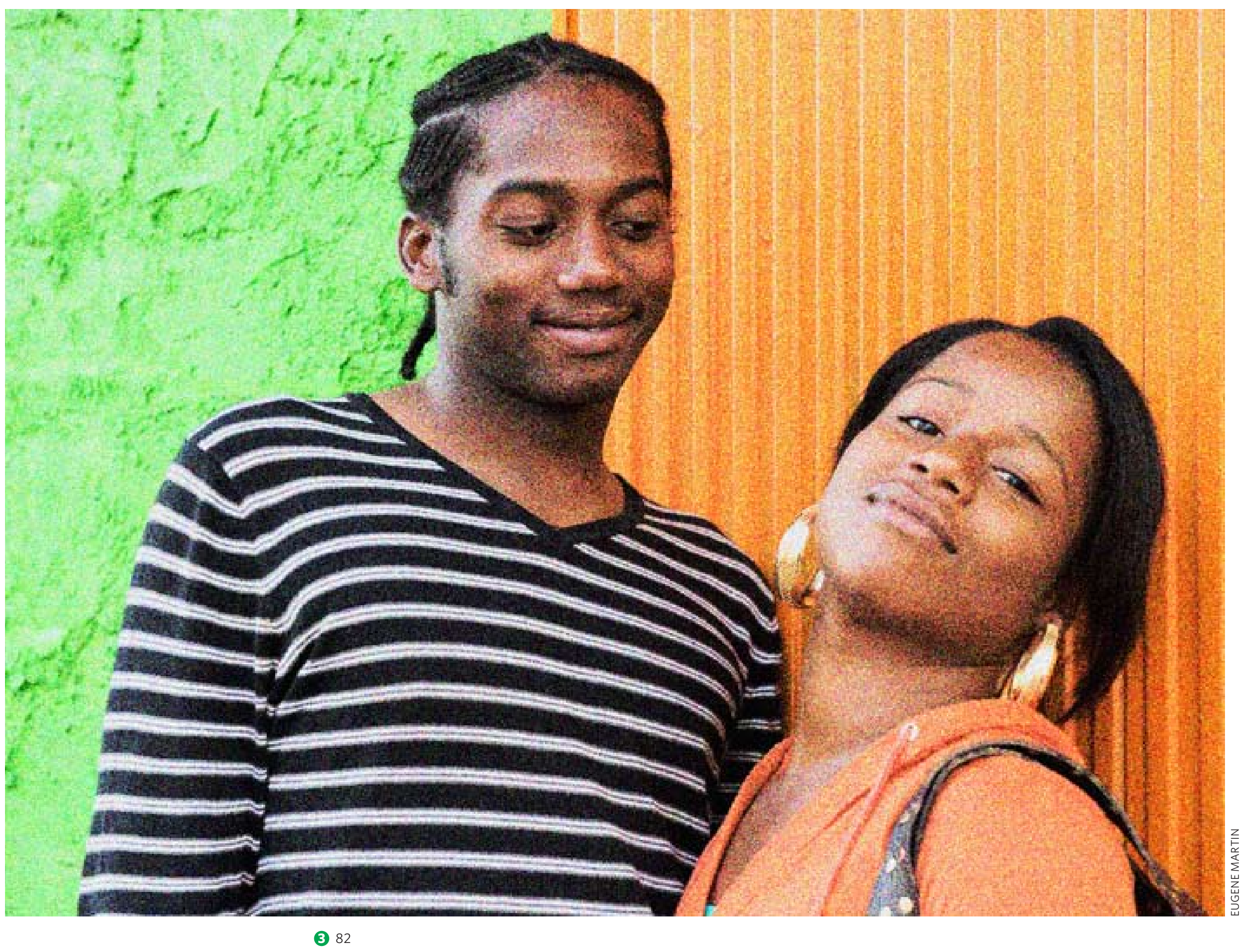




\section{SEXUALIDAD}

El material en esta unidad prepara a las y los estudiantes para:

\section{Objetivos cognoscitivos}

Analizar en grupo al menos tres razones por las que las personas desean tener relaciones sexuales; $y$, al menos tres razones, por las que las personas tienen relaciones sexuales que no desean tener.

Definir los conceptos de respeto, reciprocidad y gozo aplicados a las relaciones sexuales.

Definir y analizar en grupo al menos tres derechos sexuales, incluido el derecho a rehusarse a tener relaciones sexuales no deseadas bajo cualquier circunstancia.

Explicar al menos dos formas en que las normas sociales y las leyes afectan las actitudes y experiencia de las personas acerca de la sexualidad.

Analizar en grupo las normas sociales relacionadas con las diversas formas de expresión sexual y la forma en que tales estándares han cambiado o están cambiando.

Definir los conceptos de consentimiento y abuso en términos de su aplicación a las relaciones sexuales.

Identificar las partes del cuerpo que desempeñan un rol en el placer sexual.

\section{Objetivos afectivos}

Reflexionar sobre las formas de promover y proteger un sentido responsable y positivo de su sexualidad.

Reflexionar sobre sus propios sentimientos, motivaciones y experiencias acerca de la toma de decisiones relacionadas con la sexualidad.

Definir y expresar actitudes hacia los diferentes estándares de comportamiento sexual y placer para hombres y mujeres.

Aclarar sus propias actitudes acerca de la diversidad sexual. 


\section{acerca de la sexualidad}

1 La sexualidad es una dimensión de la vida. La sexualidad se experimenta a través de pensamientos, sentimientos y prácticas.

- La sexualidad puede expresarse con uno mismo o con otras personas.

- La sexualidad incluye deseos o prácticas que involucran a alguien del otro sexo, del mismo sexo, o ambos.

- Las personas son seres sexuales a lo largo de sus vidas. En algunos períodos, sin embargo, la mayoría de las personas experimentan poco o ningún deseo sexual.

- En diferentes momentos la mayoría de nosotros experimentará diferentes emociones relacionadas con la sexualidad. Podemos sentir excitación, confusión, angustia, felicidad o muchos otros sentimientos. Tales emociones pueden ser intensas o, en otros momentos, leves.

2 Desarrollar comodidad y confianza acerca de la sexualidad es parte del crecimiento. Esa comodidad se ve también influida por factores y experiencias individuales, familiares y sociales.

[Ver sección titulada Sexualidad y Sociedad en esta Unidad.]

3 La sexualidad - expresada individualmente o en una situación de mutuo consenso y respeto con una pareja - puede ser fuente de placer y significado en la vida. Puede aumentar la felicidad, el bienestar, la salud y la calidad de vida. Puede también fomentar la intimidad y la confianza en la pareja. 


\section{derechos sexuales}

Los derechos humanos de la mujer incluyen su derecho a tener control sobre las cuestiones relativas a su sexualidad, incluida su salud sexual y reproductiva, y decidir libremente respecto de esas cuestiones, sin verse sujeta a la coerción, la discriminación y la violencia. Las relaciones igualitarias entre la mujer y el hombre respecto de las relaciones sexuales y la reproducción, incluido el pleno respeto de la integridad de la persona, exigen el respeto y el consentimiento recíprocos y la voluntad de asumir conjuntamente la responsabilidad de las consecuencias del comportamiento sexual (Párrafo 96, Plataforma para la Acción FWCW, 1995).

\section{Todas las personas deben poder gozar de su sexualidad.}

\section{Un aspecto crítico de la experiencia sexual es que sea voluntaria y deseada por ambos} miembros de la pareja.

[Ver sección titulada Consentimiento Sexual y Coerción en esta Unidad.]

- El consentimiento sexual implica decidir libre y voluntariamente si participar o no en una actividad sexual con otra persona.

- Debido a que las personas pueden tener sentimientos en conflicto o confusos acerca de si desean tener o no relaciones sexuales, o si pueden con facilidad rehusarse a tener relaciones sexuales no deseadas, el asegurar el consentimiento puede ser un asunto complicado.

- Conforme la gente joven madura, también evoluciona su capacidad de otorgar consentimiento consciente.

3 Algunos aspectos de la sexualidad son asuntos de derechos humanos; con frecuencia se les llama derechos sexuales.

Los derechos sexuales se basan en acuerdos y pactos internacionales. Los derechos sexuales incluyen el derecho a:

- elegir parejas sexuales y formar relaciones basadas en la decisión y el consentimiento;

- aceptar o rechazar las relaciones sexuales;

- expresar la sexualidad, incluido el derecho a buscar el placer, en el contexto del consentimiento;

- gozar de autonomía corporal, libre de violencia o explotación sexual;

- obtener información completa y exacta, educación y servicios; y

- protegerse a sí misma contra el embarazo no deseado y la infección, incluido el VIH.

\section{Las personas también tienen responsabilidades en relación con su sexualidad.}

Por ejemplo, estas responsabilidades incluyen:

- asegurar el consentimiento; y

- proteger su propia salud y la de sus parejas. [Ver Unidad 7, páginas 200-201.] 


\section{sexualidad y sociedad}

\section{PUNTOS PARA REFLEXIÓN}

Las expectativas sociales y leyes afectan lo que aprendemos y pensamos sobre la sexualidad. Por ejemplo:

¿Cuánto diálogo abierto hay sobre el cuerpo y los sentimientos de placeren las clases de educación sexual, en las familias y en la comunidad?

¿Las políticas aseguran el acceso de las niñas adolescentes al aborto seguro?

¿Qué tan respetuosamente la mayoría de las personas tratan a las parejas del mismo sexo?

¿En general, cómo son tratadas las personas que viven con alguna discapacidad, en especial con respecto a sus deseos y derechos sexuales?

¿En general, de qué forma son tratadas las personas que viven con el VIH o SIDA?

Cuando las mujeres son violadas, ¿cómo son tratadas por sus familias y comunidades?
1 Todas las personas pueden crecer para gozar de vidas sexuales que sean seguras y satisfactorias; y que estén caracterizadas por la dignidad, la igualdad, la responsabilidad y el respeto mutuo.

2 La capacidad de una persona para desarrollar una vida sexual segura y satisfactoria depende de la familia, la comunidad y la sociedad en la que crece. Las normas sociales e incluso las leyes relacionadas con la sexualidad pueden promover - o minar - los sentimientos de autoestima, dignidad, salud y sentido de pertenencia y bienestar de todas las personas. [Ver la siguiente sección, Las Normas Sexuales Varían Según el Género.]

3 El hecho de si la gente joven asiste o no a la escuela y la calidad de su educación pueden afectar sus experiencias y su salud sexual.

- En muchos entornos, una de las mejores cosas que las niñas pueden hacer para proteger su salud sexual y reproductiva es permanecer en la escuela.

- En algunos lugares, las niñas que se embarazan son forzadas para dejar la escuela.

- Muchas escuelas promueven la igualdad de género y el empoderamiento de las niñas. Sin embargo, muchas niñas también enfrentan el acoso sexual (e incluso coerción) en la escuela o en el camino hacia o desde la escuela. La gente joven que se percibe como homosexual o transgénero también enfrenta el acoso en muchos entornos escolares. De manera creciente, las y los adolescentes están formando grupos de apoyo. En algunos lugares, tales grupos se llaman a sî mismos alianzas "gay-heterosexuales".

- Toda la gente joven tiene el derecho a obtener información. ${ }^{1}$ Un número creciente de escuelas están tratando de proveer educación dirigida a capacitar a sus estudiantes para que tengan vidas sexuales responsables y seguras, así como para evitar la infección por VIH. Algunas personas jóvenes también reciben información exacta acerca de la sexualidad, el género y los derechos humanos de sus familias, comunidades y los medios. [Ver inciso número 4, más adelante.]

1 Varios acuerdos internacionales de derechos humanos establecen el mandato para que los gobiernos proporcionen educación a la gente joven que les permita tomar decisiones sobre su propia salud y hacerse responsables de ella, así como para lograr un respeto mutuo en asuntos relativos a la sexualidad y la fecundidad, con especial atención en la promoción de la igualdad de género. (Párrafos 107.a, 107.e, 281.e, Plataforma para la Acción FWCW, 1995; Artículo 13.1 y 28.1, CRC, 1989; Artículo 26.1, UDHR,1948; Artículo 13.1, ICESCR, 1966; Artículo 10, CEDAW, 1979). [Ver sección sobre Sexualidad y Derechos Sexuales.] 
4 Los medios - incluidos los libros, la televisión, los filmes y los videos musicales - generan imágenes que influyen en nuestras actitudes, sentimientos y expectativas sobre la sexualidad.

- Estas imágenes pueden promover nociones positivas y precisas acerca de la sexualidad. Con frecuencia, sin embargo, las imágenes de los medios reflejan nociones estrechas y erróneas sobre la sexualidad.

- En términos de sexo, no hay una forma única de ver o comportarse que sea correcta, mientras que se asegure el consentimiento y la seguridad. En cambio, la diversidad sexual existe en todas partes.

5 Todas las personas deben poder participar en la vida política, profesional y cívica sin discriminación. Las normas sexuales no deben presentar obstáculos para tal participación.

- Desafortunadamente, algunas personas pueden enfrentar discriminación, humillación o pérdida del empleo debido a que no se ajustan a las normas sexuales prevalecientes. Por ejemplo, alguien con una pareja del mismo sexo, una mujer no casada que es sexualmente activa o que tiene más de una pareja, o alguien que viva con el SIDA, puede sufrir tales prejuicios.

- Ese tipo de discriminación es violatoria de los derechos definidos en muchos documentos de derechos humanos. ${ }^{2}$

\section{Alrededor del mundo la gente joven crece con diferentes actitudes y leyes relacionadas} con las relaciones sexuales y el matrimonio.

- La mayoría, pero no todas las personas jóvenes, desean formar una relación y casarse.

- En algunos lugares, existe amplio y creciente apoyo para las relaciones del mismo sexo, incluido el derecho a casarse o formar una unión reconocida legalmente. En muchos otros lugares, sin embargo, ese tipo de apoyo no existe.

- Las personas que viven con el VIH o SIDA pueden enfrentar temores o discriminación acerca del matrimonio; pero millones de parejas tienen matrimonios exitosos en los cuales el VIH es una realidad.

- En algunos lugares, las leyes todavía permiten la violación marital (relaciones sexuales maritales sin el consentimiento conyugal) o no la reconocen como agresión.

\section{PUNTOS PARA REFLEXIÓN}

¿Qué impresiones e ideas sobre la sexualidad obtenemos de los filmes, la televisión y los videos musicales?

¿Cuánta gente se ajusta a la imagen de atractivo sexual tal y como se presenta en los medios?

¿Qué impresiones recibimos de los medios acerca de la forma en que debemos actuar en las relaciones?

¿De qué forma los filmes presentan a las personas que tienen relaciones sexuales con otras del mismo sexo?

¿Cómo se sienten las personas cuando su propia apariencia o identidad es muy diferente de lo que muestran los medios?

¿De qué forma reflejan los medios la diversidad que existe en la sociedad?

A menudo, los medios de comunicación usan imágenes que sexualizan a la gente joven, especialment a las niñas. ¿Qué efecto creés que esto tiene para las niñas? ¿Para los niños? ¿Para los adultos? 
7 Las religiones y los líderes religiosos mantienen una variedad de perspectivas sobre la sexualidad y pueden tratar de influir en las normas y políticas relacionadas con los temas de sexualidad y derechos sexuales.

Estas normas y políticas incluyen, por ejemplo, aquellas relacionadas con [ver también la Unidad 2, páginas 62-63]:

- educación sexual;

- abstinencia y virginidad;

- anticoncepción y aborto;

- homosexualidad;

- mutilación genital; y

- matrimonio.

8 Las normas culturales y las leyes locales concernientes a la sexualidad no son estáticas. Varían de lugar a lugar y cambian a través del tiempo.

9 Muchas personas interactúan con la sociedad y mucha gente joven aporta a la sociedad sus actitudes independientes acerca de la sexualidad y los derechos. La gente joven debe sentirse orgullosa de sí misma y saber que es importante para la sociedad.

VER EL LIBRO DE ACTIVIDADES Actividad 17

debate sobre la educación sexual

Las y los estudiantes debaten sobre si la gente joven debe aprender acerca de la sexualidad, el género y la salud sexual; o si deben aprender solamente a abstenerse de tener relaciones sexuales hasta el matrimonio. 


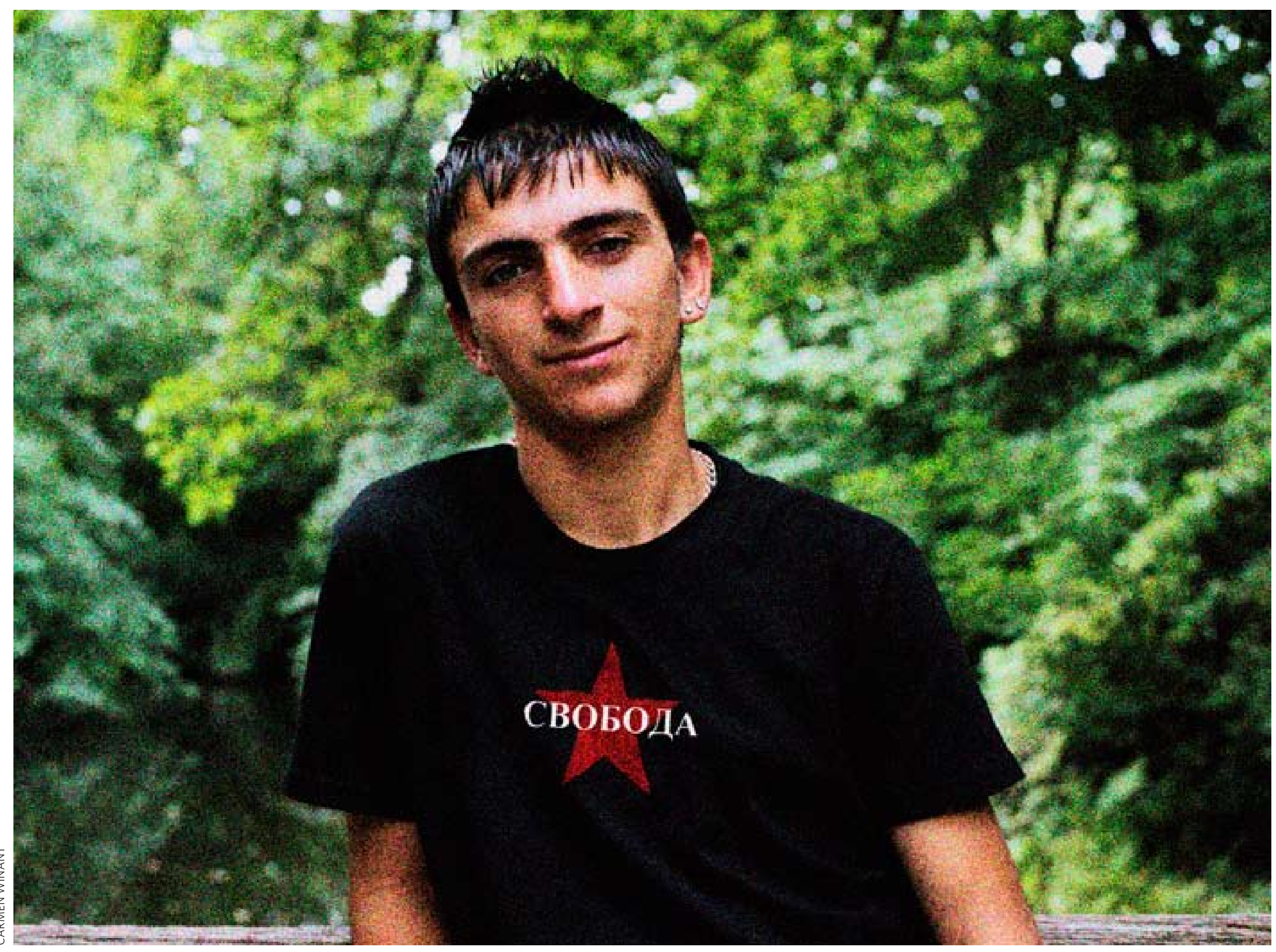




\section{las normas sexuales varían según el género: el "doble estándar" para el comportamiento sexual}

VER EL LIBRO DE ACTIVIDADES Actividad 18

primeras impresiones

Las y los estudiantes examinan sus reacciones hacia un personaje en una historia, con base en sus suposiciones sobre si el personaje es hombre o mujer.
1 Con frecuencia se permite a los niños, o incluso se les presiona para ser sexualmente activos, siempre y cuando sus deseos sexuales se dirijan hacia las mujeres.

Por ejemplo:

- Algunos niños son alentados para que retrasen su actividad sexual y ellos mismos pueden desearlo. Sin embargo, con frecuencia sienten fuertes presiones para "probar su hombría" a través de experiencias heterosexuales tempranas, repetidas y algunas veces incluso agresivas.

- En muchos entornos comúnmente se espera que niños y hombres tomen riesgos (incluidos los sexuales).

2 Con frecuencia las niñas reciben mensajes contradictorios relativos al sexo.

- A muchas de ellas se les enseña que no deben ser sexualmente activas antes de contraer matrimonio. Ellas pueden ser castigados por actividad sexual.

- Al mismo tiempo, se espera que las niñas sean sexualmente atractivas. Imagenes de los medios de comunicación "sexualiza" a las niñas desde una edad temprana.

- Con frecuencia, se acostumbra a las niñas para que sean sumisas ante sus novios y esposos, y ante los hombres en general.

- Algunas niñas experimentan presión en tener relaciones sexuales con el fin de demonstrar su fecundidad.

3 Ciertas expectativas se aplican tanto a los niños como a las niñas.

- Las personas cuya apariencia o comportamientos se apartan de las expectativas sociales pueden ser acosadas o amenazadas. Con frecuencia, los niños y hombres cuyo comportamiento se percibe como femenino son tratados en forma irrespetuosa o cruel.

- Muchas personas sienten presión para alterar la apariencia de sus cuerpos con el fin de ajustarse a las ideas culturales de lo que es atractivo sexualmente. Típicamente, las niñas se ven sujetas a estas presiones de manera más intensa que los hombres. 
4 Las normas sexuales muchas veces reflejan y refuerzan actitudes estrechas o mal informadas acerca de la sexualidad de otros grupos. Por ejemplo, tales actitudes pueden estar dirigidas a las personas de mayor edad, a aquellas que viven en condiciones de pobreza, a quienes pertenecen a ciertos grupos étnicos o raciales, a quienes viven con alguna discapacidad, o a las personas que se sienten atraídas hacia otras del mismo sexo.

5 Cada uno de nosotros decide qué tanto está de acuerdo con las normas locales relacionadas con la sexualidad. Cuando estamos en desacuerdo con ciertas normas y expectativas, podemos considerar si cumpliremos con ellas o si podemos vivir conforme a nuestras propias convicciones.

La experiencia de ser hombre o mujer no es la misma en todas partes o para todos los grupos. Por ejemplo:

¿Cómo son vistas por la sociedad las mujeres de mayor edad en términos de su sexualidad?

¿Se etiqueta a los hombres de ciertos grupos étnicos como altamente sexuales o asexuales?

Una persona a la que se le percibe como homosexual puede estar sujeta al estigma. ¿Es menor ese estigma si la persona resulta también ser rica?

¿Por qué las niñas que viven con alguna discapacidad mental tienen mayor propensión a ser víctimas de abuso sexual?

Piense en una persona a la que usted conoce y admira, y que vive conforme a sus propias creencias y valores, aún si esos valores difieren de los de la sociedad en general. ¿Piensa usted que esa persona sufre algunas dificultades por vivir de esa manera? ¿Por qué admira usted a esa persona? 


\section{deseo sexual}

1 Hay muchas maneras en que las personas experimentan el deseo sexual (un anhelo por una expresión sexual o un sentimiento de atracción sexual). No hay una única forma "normal" de experimentar el deseo sexual.

- Virtualmente, toda persona experimenta el deseo sexual, algunas veces de una naturaleza intensa. Las personas pueden sentir deseo por otra persona (del mismo sexo, del otro sexo, o ambos). O puede sentir un deseo generalizado que no necesariamente se asocia a otra persona.

- Dentro de una relación íntima, una persona puede sentir deseo sexual más que la otra.

- El nivel de deseo sexual de las personas puede cambiar en un corto período o a lo largo de sus vidas. Pueden experimentar deseo sexual hasta el final de sus vidas, aunque su respuesta física puede cambiar con la edad.

- Las personas experimentan deseo sexual en respuesta a una amplia variedad de estímulos. Tanto las preferencias personales, como las experiencias de vida y normas culturales influyen en estas respuestas.

2 Varios factores sociales, emocionales y físicos dan forma al deseo de las personas de expresarse sexualmente. Estos factores con frecuencia están interrelacionados.

- Algunos factores están relacionados con el cuerpo, como los niveles de hormonas, alcohol y ciertas drogas, la fatiga, o la enfermedad.

- Algunos factores están relacionados con las emociones, como el sentirse respetado y comprendido en una relación, o como haber sufrido una experiencia de abuso sexual.

- El medio ambiente social puede también influir en la expresión de deseo. Por ejemplo:

- La falta de privacidad o sentimientos de nerviosismo y timidez pueden dificultar la expresión del deseo.

- Las normas de género hacen que algunos niños sientan que deben desear tener relaciones sexuales aún cuando no sea así. En contraste, las mujeres, la gente joven, las personas que viven con discapacidades y las que se sienten atraídas hacia personas del mismo sexo pueden ser educadas en el sentido de que expresar su deseo sexual es algo incorrecto. 
3 Con frecuencia las personas confunden el deseo o atracción sexual con otras experiencias emocionales o físicas.

- El deseo sexual no es lo mismo que el amor, aunque muchas veces se le confunde con el amor. Una persona puede experimentar deseo sexual con o sin amor. Por ejemplo, una persona puede sentir deseo sexual para alguien a quien él o ella apenas conoce. [Ver Unidad 4.]

- El deseo sexual no es lo mismo que una respuesta sexual física. Por ejemplo, un niño o un hombre puede tener una erección sin sentir deseo. $\mathrm{O}$ bien, puede experimentar deseo sin tener una erección.

- El deseo sexual no es lo mismo que la actividad sexual. Una persona que experimenta deseo sexual puede elegir actuar o no conforme a ese deseo. La actividad sexual puede o no surgir del deseo. Tener actividad sexual puede o no aumentar el deseo.

\section{Para muchas personas, la fantasía puede crear o aumentar el deseo.}

- Pensar acerca del acto sexual es algo normal, no vergonzoso.

- Fantasear acerca de un acto no significa necesariamente que deseemos participar en ese acto. No significa que la persona que tiene la fantasía va a actuar conforme a ella.

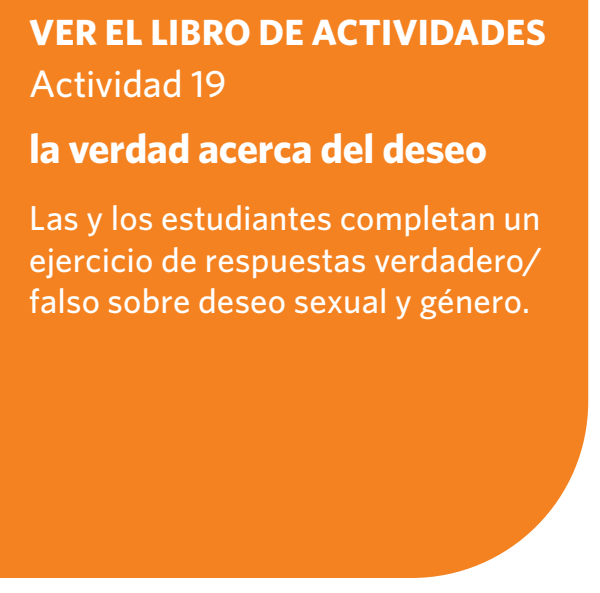




\section{diversidad sexual}

Nota sobre terminología: Atracción al mismo o al otro sexo se puede llamar orientación sexual, identidad sexual, o se puede usar algún otro término. Este documento utiliza los términos identidad sexual y diversidad sexual para referirse a la amplia gama de expresiones sexuales. Las personas que se sienten atraídas hacia otras del mismo sexo también usan diferentes términos para describirse a sí mismas; algunas prefieren el término homosexual, mientras que otras usan gay, lesbiana o algún otro término. Lo que se considera apropiado y también respetuoso en un entorno, puede considerarse como ofensivo en otro. Ese documento usa atracción del mismo sexo y homosexual de manera intercambiable. Por favor utilice los términos que sean más apropiados para su currículo.
1 En primer lugar, todos somos personas. Todas y todos nosotros tenemos similitudes y diferencias en comparación con otras personas en nuestras familias, escuelas, centros de trabajo y comunidades. Por ejemplo, hay una amplia variación en nuestra apariencia y en la forma como pensamos, en nuestros talentos y en nuestra sexualidad. Esta diversidad de experiencias humanas existe en todas partes.

2 La variación en los deseos, comportamientos e identidades sexuales de las personas se conoce como diversidad sexual.

3 Las personas pueden experimentar sentimientos de amor, atracción y deseo sexual hacia el otro sexo, hacia el mismo sexo, o hacia ambos. Esta variación siempre ha sido una realidad a través de la historia. Esto es una realidad en todas las sociedades, sin importar si la sociedad acepta o no la atracción del mismo sexo.

- El término heterosexual se usa para describir a las personas que desean a personas del otro sexo. El término homosexual se usa para describir a personas que desean a personas de su mismo sexo. En algunos contextos se prefieren estos términos, mientras que en otros se utilizan términos diferentes (ver Nota al margen).

- Como todo el mundo, las personas transgénero (personas cuya identidad de género difiere del sexo que les fue asignado al nacer) pueden sentir atracción hacia personas del mismo sexo, del otro sexo o ambos.

- Las personas pueden o no identificarse como heterosexuales, homosexuales (gay o lesbiana) o bisexuales (atraídas hacia personas tanto del mismo como del otro sexo).

- Las personas pueden ser etiquetadas con una identidad sexual que ellas mismas no consideran tener. Algunas personas no desean ser etiquetadas o categorizadas en términos de su sexualidad o identidad sexual, independientemente de sus deseos.

- Lo que determina si una persona experimenta deseo por el mismo sexo, el otro sexo, o ambos, todavía no es bien comprendido. Estos deseos no pueden cambiarse con base en la religión, terapia o intervención médica. Los deseos, comportamiento o identidad de una persona pueden cambiar en el tiempo y de una situación a otra.

4 Puede encontrarse a personas que son heterosexuales, homosexuales, bisexuales o transgénero en cualquier tipo de familia, comunidad, religión y profesión. 
5 Por tratarse de un asunto de derechos humanos, las personas pueden participar en relaciones que ellas elijan y que sean consensuales.

\section{En cada sociedad, los sentimientos individuales sobre diversidad sexual y} homosexualidad varían.

- Algunas personas se sienten cómodas con la diversidad sexual y la celebran. Otras pueden sentir temor o incluso odio hacia las personas que son homosexuales. Algunas otras tienen sentimientos encontrados. El temor o la aversión hacia las personas homosexuales se llama homofobia.

- Los sentimientos de las personas con frecuencia son reflejo de normas locales. Tales normas varían a lo largo de un continuo que incluye: el estigma y la discriminación (por ejemplo, rehusarse a proporcionar vivienda o empleo a la persona); rechazo (por ejemplo, hacer burla de alguien); tolerancia; aceptación; respeto; y, finalmente, la valoración y adopción de la diversidad.

7 Desafortunadamente, el rechazo, el estigma y la discriminación hacia las personas que desean o se involucran en experiencias o relaciones con el mismo sexo están generalizados. Ese estigma y discriminación daña a las personas y viola sus derechos humanos.

- Ridiculizar a alguien porque se sienta atraído a otras personas del mismo sexo puede causar que la persona se sienta aislada o avergonzada.

- En donde se estigmatiza la homosexualidad, quienes que se sienten atraídas hacia otras personas del mismo sexo pueden encontrar dificultad o sentir temor para reconocer sus propios sentimientos sexuales o para revelar públicamente estos sentimientos.

- Algunas personas se identifican públicamente como heterosexuales, aún cuando sientan deseo sexual en gran parte (o exclusivamente) por individuos de su mismo sexo.

- Los niños que no actúan de manera "suficientemente masculina" pueden ser intimidados para que se comporten en formas que no les sean cómodas.

\section{PUNTOS PARA REFLEXIÓN}

¿Las personas a quienes se percibe como homosexuales enfrentan discriminación cuando buscan empleo o vivienda?

¿Por qué las personas homosexuales tienen altas tasas de depresión y suicidio en algunas sociedades, pero no en otras? ¿Cómo se sentiría cualquiera de nosotros si estuviéramos aislados solamente por ser quienes somos?

¿Por qué una persona que se sienta atraída hacia alguien del mismo sexo podría identificarse en público como heterosexual e incluso casarse con alguien del otro sexo?

¿Cuáles son algunas razones por las que un niño podría acosar o intimidar a otro niño por no ser suficientemente masculino? ¿De qué forma tal comportamiento viola la dignidad de la persona que es acosada? 
VER EL LIBRO DE ACTIVIDADES Actividad 20

\section{sentir diferente}

Las y los estudiantes identifican cómo se siente ser similares o

diferentes a otras personas y

reafirman los derechos humanos

de los grupos minoritarios,

incluidas las minorías sexuales.

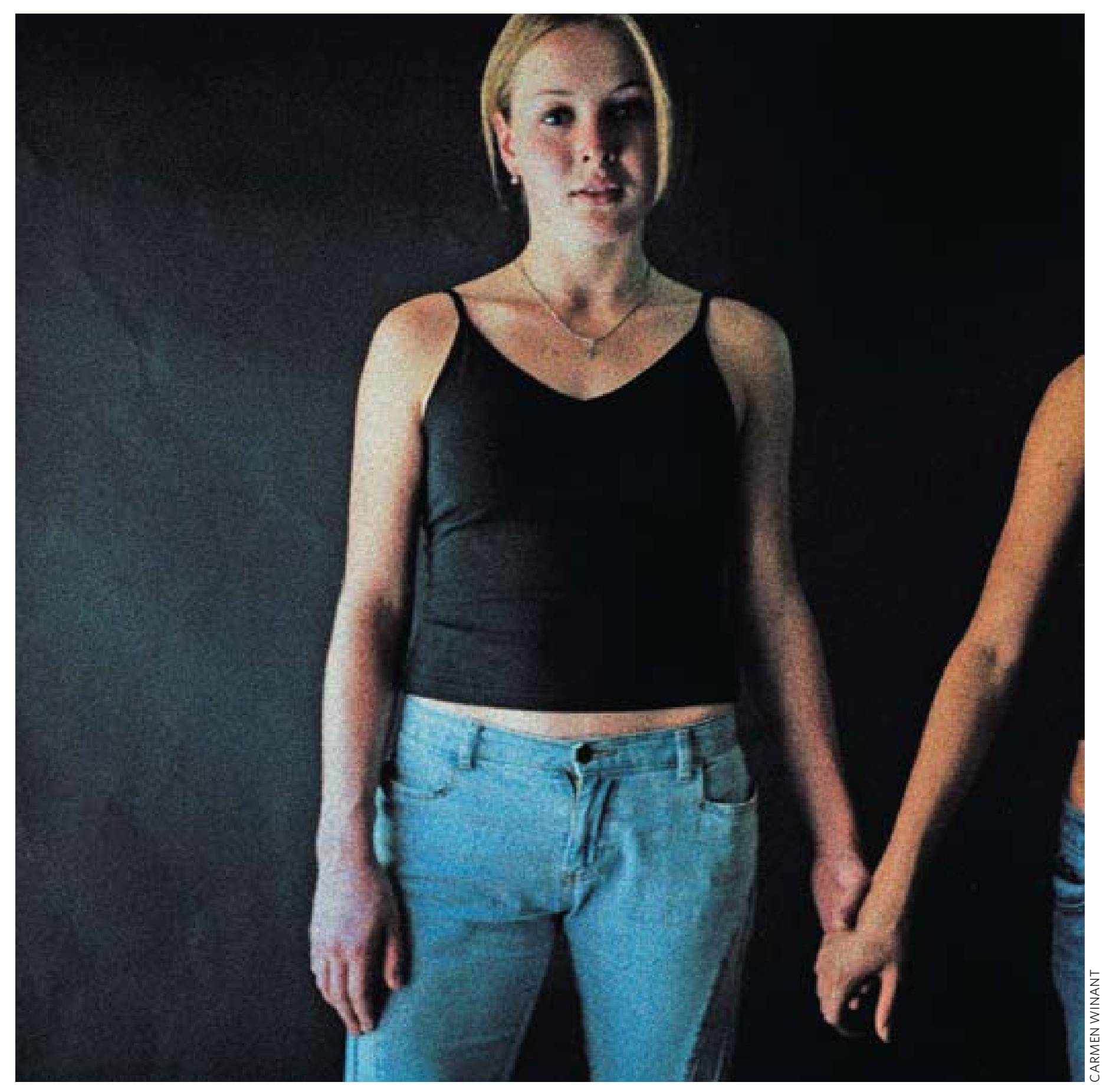


8 Todas las personas deben poder participar en la vida política, profesional y cívica sin discriminación. Las normas sexuales no deben presentar obstáculos para tal participación.

9 El cambio hacia la aceptación de la diversidad sexual está ocurriendo gradualmente en muchas partes del mundo.

- Millones de personas — tanto homosexuales como heterosexuales — están trabajando para apoyar el derecho de las personas a elegir sus parejas sexuales y para formar relaciones basadas en el consentimiento mutuo.

- En escuelas secundarias de todo el mundo, grupos de estudiantes han formado alianzas "gay-heterosexuales" para oponerse a la homofobia y educar a otras personas acerca de la diversidad sexual.

- Muchas instituciones de derechos humanos, derechos civiles y de salud pública han emitido declaraciones relacionadas con los derechos de todas las personas. Estas declaraciones apoyan el derecho de las personas a elegir sus parejas sexuales y de formar relaciones basadas en el consentimiento mutuo.

- En algunos casos los medios están ayudando también a generar cambios en las actitudes sociales y leyes acerca de la diversidad sexual.

- Aún en entornos conservadores, en donde las relaciones del mismo sexo han sido tabú, las personas están encontrando formas de entablar diálogos respetuosos y compasivos en torno a este tema.

10 La discriminación en contra de una persona con base en su identidad sexual, deseo o comportamiento consensual es una violación de sus derechos humanos.

VER EL LIBRO DE ACTIVIDADES Actividad 21

sentir atracción sexual hacia alguien del mismo sexo: historias personales

Las y los estudiantes leen tres historias de adolescentes que se dan cuenta de que no son heterosexuales y analizan en grupo las reacciones de estas personas. Se corrige la desinformación. 


\section{anatomía y placer sexual}

\section{PUNTOS PARA REFLEXIÓN}

El cerebro actúa como mediador de muchas funciones relacionadas con el sexo. ¿Cuáles son algunas de las formas en las que el cerebro (o la mente) influye en la experiencia y placer sexual de una persona?

Algo que sea sexual o erótico en una situación puede ser poco estimulante o incluso desagradable en otra situación. ¿Cómo podría usted explicar esto?
1 El cerebro está profundamente involucrado en la experiencia y placer sexual. Responde al insumo de hormonas y procesa las emociones. Algunas personas dirían que el cerebro es el órgano sexual más importante.

2 Cualquier área del cuerpo puede responder al estímulo sexual. Por ejemplo, una persona puede sentir placer sexual a partir de una caricia en el rostro, el estómago, los pezones, las orejas, las piernas o en cualquier otra parte. Cada persona tiene diferentes respuestas; y la respuesta de cada persona depende de la situación en que se encuentra.

3 Ciertas partes del cuerpo que contribuyen al placer sexual son específicas para los hombres o para las mujeres:

[Ver hojas informativas sobre Anatomía y Placer Sexual y sobre Sistemas Sexuales y Reproductivos.]

- En los niños y los hombres, incluyen el pene, los testículos, el escroto y la próstata.

- En las niñas y las mujeres, estas partes incluyen el clítoris, la vulva, la vagina y los pechos.

- El clítoris (no la vagina) es la parte del cuerpo femenino que es más sensible a la estimulación sexual. La mayoría de las mujeres llegan al orgasmo (clímax sexual) como resultado de la estimulación del clítoris (más que por la penetración del pene en la vagina). Desafortunadamente, muchas personas no comprenden este hecho básico.

4 La forma en que el cuerpo responde a la estimulación sexual involucra varios procesos psicológicos.

Por ejemplo:

- Aumenta el ritmo cardiaco.

- Fluye sangre hacia el área genital. En los hombres este flujo sanguíneo puede causar una erección.

- El cuerpo secreta fluidos. En las mujeres, la vagina puede humedecerse. En los hombres, el pene puede liberar algunas gotas de pre-eyaculación (que no es el mismo fluido que el de la eyaculación).

- La forma en que el cuerpo responde al estímulo sexual varía según la situación y de persona a persona. 


\section{expresión y gozo sexual}

1 El placer emocional y el físico son partes importantes del bienestar sexual.

Organizaciones de salud pública y derechos han emitido declaraciones relacionadas con los derechos de todas las personas a la expresión sexual. Estos derechos incluyen el de

buscar el placer en el contexto de la seguridad y del consentimiento mutuo y consciente.

2 Lo que es sexualmente placentero varía según la persona.

- Las personas pueden experimentar el placer sexual tocándose a sí mismas o a través de una experiencia compartida (con alguien del mismo o del otro sexo). También, pueden experimentar placer sexual en ausencia de caricias.

- Las fuentes de placer sexual pueden incluir fantasías, palabras, lecturas, ver un filme, caricias, besos o contacto genital.

- Para que la relación sexual produzca gozo, las personas deben saber lo que se siente bien para ellas mismas y para sus parejas.

3 Tocarse o acariciarse uno mismo (especialmente los propios genitales) para obtener placer sexual se llama masturbación.

[Ver la siguiente sección titulada Comportamiento Sexual.]

- La masturbación es una forma importante en la que la gente aprende acerca de su cuerpo y sexualidad.

- La mayoría de las personas buscan el placer a través de la masturbación a lo largo de sus vidas, incluidos los períodos en los que tienen pareja sexual o están casadas

- La masturbación es un comportamiento sexual seguro. No es dañino ni física ni mentalmente. 


\section{PUNTOS PARA REFLEXIÓN}

¿Cómo se comparan las actitudes respecto a la virginidad femenina con las actitudes respecto a la virginidad masculina?

¿De qué forma trata la gente a los niños que han tenido más de una pareja sexual? ¿Cómo tratan a las niñas que han tenido más de una pareja sexual?

¿Qué mensajes sobre el placer sexual envían la educación de sólo abstinencia, el matrimonio infantil y la mutilación genital femenina?

¿Piensa usted que la mayoría de los hombres jóvenes comprenden la forma en que la mayoría de las mujeres llegan al orgasmo (a través de la estimulación del clítoris, más que a través de la penetración vaginal)?
4 La excitación sexual puede llegar a un punto máximo o clímax, que se llama orgasmo. Junto con un sentimiento de euforia, el orgasmo involucra la contracción involuntaria y relajación de los músculos y secreción de fluido (eyaculación, con semen en los hombres; lubricación genital en las mujeres).

[Ver sección previa titulada Anatomía y Placer Sexual.]

- Muchas mujeres llegan al orgasmo a través de la estimulación del clítoris. Como parte del conocimiento de su propio cuerpo, una niña debe tener la oportunidad de aprender sobre la función del clítoris.

- Parte de lo que nos hace sentir placer con el orgasmo es un aumento en el nivel de endorfinas. Estas son sustancias químicas producidas en nuestro cerebro, que reducen el dolor y nos hacen sentir bien.

- Las personas pueden experimentar el orgasmo sin coito o coito sin orgasmo.

- El sentirse presionado para tener un orgasmo puede reducir el placer sexual y dificultar o imposibilitar el orgasmo.

- Las mujeres que han sido sometidas a mutilación genital aún así pueden experimentar placer sexual. [Ver hoja informativa sobre Mutilación Genital Femenina.]

5 Idealmente, ambos miembros de la pareja en una relación sexual tienen interés en asegurar el placer de su pareja así como de sí mismos. Sin embargo, puede haberse enseñado tanto a los hombres como a las mujeres que los hombres (en particular los heterosexuales) tienen más derecho que las mujeres de buscar el placer sexual.

6 Mientras que la actividad sexual se lleve a cabo con consentimiento mutuo y consciente; y que no sea dañina, no hay una forma que pueda considerarse como verdadera o mejor de gozarla.

7 La mayoría de las personas desean que su pareja sexual experimente placer. Sin embargo, careciendo de la información adecuada sobre su propio cuerpo o el de su pareja, muchas personas no tienen claro cómo hacer para provocar ese placer. Por ejemplo, pueden no saber sobre el clítoris. O pueden no sentir comodidad al hablar de lo que produce una mejor sensación. 


\section{comportamiento sexual}

1 Las personas - sin importar su identidad sexual, género o capacidad física - pueden expresar y experimentar su sexualidad a través de una variedad de comportamientos sexuales. No hay una práctica sexual que sea mejor (o peor) que otra - en tanto los miembros de la pareja se respeten mutuamente, ninguno resulte perjudicado y que ambos miembros de la pareja otorguen su consentimiento.

2 Las y los niños tienen curiosidad acerca de los cuerpos y la reproducción.

- La mayoría de las y los niños tocan sus genitales porque se siente bien; esto se llama masturbación. Las y los niños pequeños no se masturban con una intención sexual. [Ver la sección anterior titulada Expresión y Gozo Sexual.]

- Aunque la masturbación es segura, es desalentada o incluso estigmatizada dentro de algunas culturas y religiones. Como resultado, muchos padres tienen dudas sobre qué decir a sus hijos en relación con esta práctica.

- Conforme las y los niños se van haciendo conscientes de sus cuerpos, pueden explorar su sexualidad con sus amistades de cualquier sexo.

3 El comportamiento sexual varía ampliamente.

Enseguida encontrará descripciones de algunos comportamientos sexuales comunes:

- La masturbación (tocarse uno mismo) sigue siendo una práctica común a través de la vida de la mayoría de las personas. La masturbación es un comportamiento sexual seguro. No es dañino ni física ni mentalmente.

- Las caricias, los besos, el compartir fantasías eróticas, estimular los genitales de la pareja con la propia mano y frotarse uno contra el otro son prácticas que pueden conducir al orgasmo y que no involucran una penetración.

- El sexo oral es el contacto de boca a genitales.

- El coito es la actividad sexual en la cual el pene entra en la vagina o el ano. Otras formas de relaciones sexuales con penetración pueden incluir el uso de los dedos o de algún objeto.

4 Las personas pueden compartir una experiencia sexual íntima sin tocarse mutuamente. Las prácticas sin penetración (sin intercambio de fluidos corporales) no conllevan los mismos riesgos para la salud que el coito y el sexo oral.

\author{
VER EL LIBRO DE ACTIVIDADES \\ Actividad 22 \\ comportamiento sexual - \\ mitos y hechos \\ Las y los estudiantes participan \\ en un juego en el que deciden \\ si los enunciados acerca del \\ comportamiento sexual son \\ verdaderos o falsos. Las ideas \\ equivocadas son corregidas \\ mediante el diálogo.
}




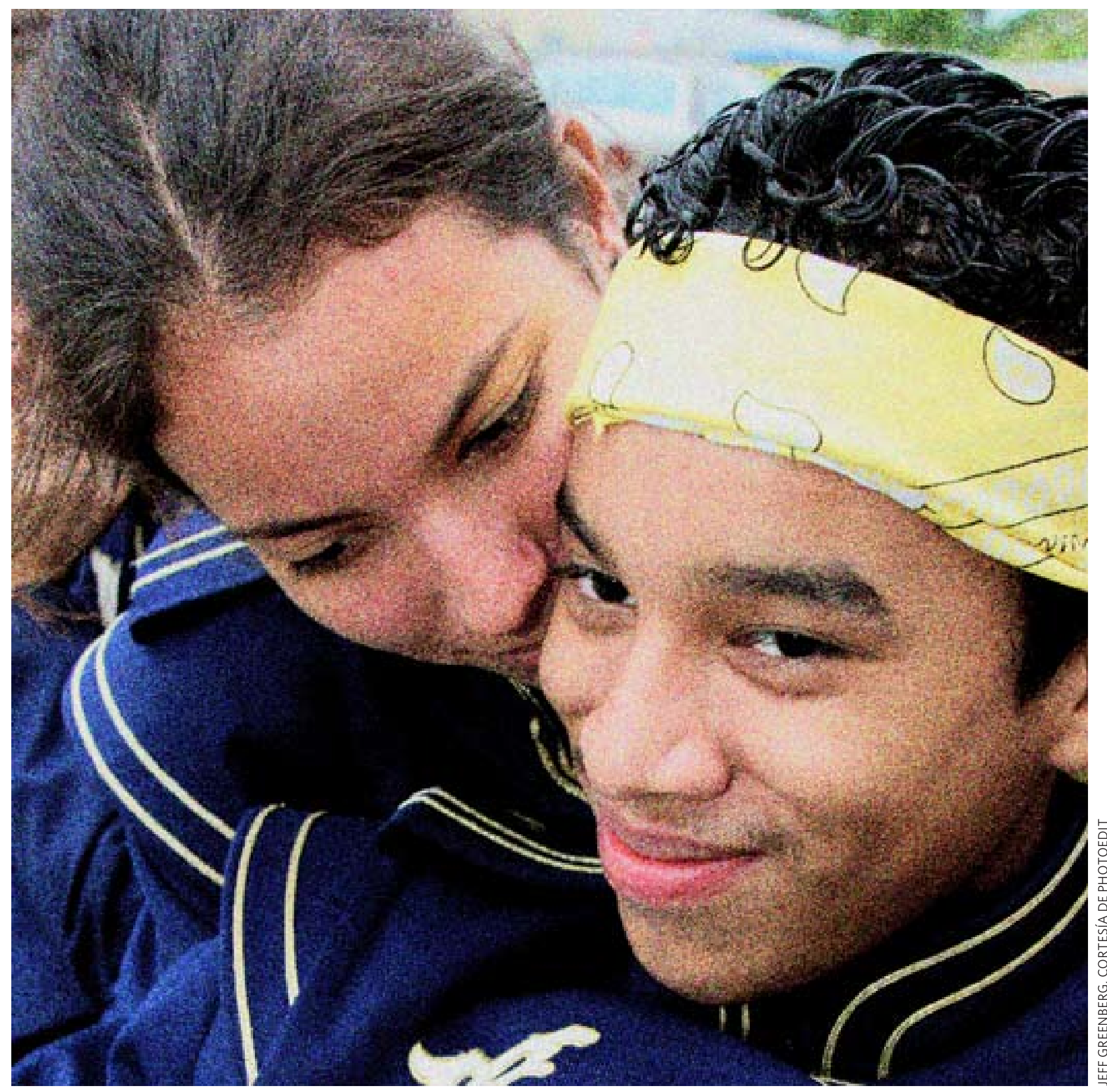




\section{motivaciones para tener o no tener relaciones sexuales}

1 Como en el caso de otras actividades, las personas tienen relaciones sexuales por muchas razones diferentes. Pueden tener más de una razón en un momento dado.

- Las razones por las que las personas se sienten motivadas para tener (o no tener) relaciones sexuales con frecuencia se ven afectadas por su edad, sexo, condición económica, el estado de su relación y otras circunstancias.

- Muchas veces, las personas tienen sentimientos encontrados respecto a las relaciones sexuales. Al mismo tiempo pueden desear tener relaciones sexuales y no tenerlas.

- Las personas, incluida la gente joven, pueden tener claro si desean tener relaciones sexuales y las razones por las que desea tenerlas. Frecuentemente, sin embargo, las personas (especialmente la gente joven) pueden sentirse confundidas a este respecto.

2 Las personas pueden querer tener relaciones sexuales en respuesta a un deseo genuino.

Por ejemplo:

- para dar o recibir placer;

- para aprender sobre su propia sexualidad y sentimientos; y

- para expresar intimidad, conexión interpersonal y amor.

3 Algunas veces, las personas desean tener relaciones sexuales fundamentalmente como medio para lograr un fin diferente. Aún si la relación sexual es consensual y segura, una persona podría decidir tenerla ante todo para tratar de satisfacer alguna otra necesidad u obligación social.

Por ejemplo:

- para "ganar" o "mantener" el amor de alguien;

- para evitar una discusión o situación de violencia potencial;

- para lograr una mejor condición social;

- para probar su masculinidad o feminidad;

- para experimentar o satisfacer la curiosidad;

- para enfrentar la autoridad de los adultos;

- para demostrar su poder sobre alguien más;

- por beneficio material (regalos o dinero), o por alimentos o supervivencia básica;

- para cumplir con las expectativas del deber marital; y

- para tener hijos. 
4 Las personas pueden tener cualquiera de una variedad de razones comunes y aceptables para no tener relaciones sexuales.

Por ejemplo:

- Simplemente no desean tenerlas, aún si no tienen una razón específica.

- Sienten que son demasiado jóvenes para tener relaciones sexuales.

- Sienten que su relación todavía no ha llegado a la etapa en la que deberían tener relaciones sexuales. Pueden sentir que su pareja no está suficientemente comprometida. Pueden no estar "enamoradas". O pueden no querer casarse.

\section{VER EL LIBRO DE ACTIVIDADES}

\section{Actividad 23}

\section{por qué lo hacemos (o no lo} hacemos)

Las y los estudiantes deciden si están de acuerdo o en desacuerdo con una serie de enunciados acerca de las razones por las que la gente decide tener - o no tener relaciones sexuales.

\section{VER EL LIBRO DE ACTIVIDADES}

\section{Actividad 24}

cen qué punto de la línea? el continuo entre la decisión y la coerción sexual

Las y los estudiantes ubican estudios de caso en el continuo entre las relaciones sexuales

forzadas y las voluntarias y deseadas; $y$ analizan en grupo el derecho a decir no.
- No confían o no sienten la suficiente comodidad o intimidad con la otra persona para tener relaciones sexuales. O no sienten que haya suficiente respeto y reciprocidad en la relación.

- No se sienten cómodas con la situación.

- Los niños, en particular, pueden sentirse ansiosos acerca de su desempeño sexual. Pueden estar preocupados por mantener una erección o por eyacular demasiado pronto.

- Les preocupa el embarazo.

- Les preocupa el VIH u otras ITS, o la posibilidad de transmitir ese tipo de infección a su pareja.

- Tienen temor por las consecuencias para su condición social.

- Tener relaciones sexuales en su situación particular va en contra de sus propios valores o principios morales.

- Su religión, sus padres o su comunidad les exige esperarse a tener relaciones sexuales hasta que estén casadas.

- Pueden tener temor de actuar con base en su atracción hacia una persona del mismo sexo.

- No han disfrutado sus pasadas experiencias sexuales. La relación sexual se ha vuelto rutinaria o aburrida en su relación.

- Se sienten enfermas, cansadas, preocupadas, molestas o enojadas. 
5 Algunas veces las personas tienen relaciones sexuales porque se ven coaccionadas o forzadas a tenerlas en contra de su voluntad. Tal tipo de abuso se conoce comúnmente como violación, violencia sexual, coerción sexual o asalto sexual. Esto es una violación a los derechos humanos. Siempre es algo incorrecto y la víctima nunca es culpable.

[Ver Unidad 2, páginas 70-71.]

- Personas de cualquier sexo pueden ser coaccionadas para tener relaciones sexuales no deseadas. Sin embargo, las niñas y las mujeres se ven forzadas a tener relaciones sexuales no deseadas con mayor frecuencia que los niños y hombres.

- La gente joven — incluidos las y los niños pequeños — también son vulnerables a la coerción sexual.

6 En ocasiones, la línea divisoria entre las relaciones sexuales voluntarias o deseadas y las relaciones forzadas es difícil de distinguir. Esto es más como un continuo.

Piense en las siguientes circunstancias:

- cuando el deseo de responder a las necesidades de la pareja se convierte en una obligación o deber poco grato;

- cuando una persona no sabe como afirmar sus propios deseos o necesidades, o no siente que tiene el derecho a decir no; o

- cuando una persona tiene temor de que rehusarse a tener relaciones sexuales tendrá graves consecuencias: violencia (ser golpeada o violada), perder una relación, o perder un empleo.

- Algunas veces la relación sexual es voluntaria pero no deseada. 


\section{consentimiento sexual y coerción}

Ver unidad 2, páginas 70-71:

La coerción sexual es una forma de violencia basada en género.

\section{VER EL LIBRO DE ACTIVIDADES} Actividad 25

\section{el tema del consentimiento}

Las y los estudiantes aprenden acerca del concepto del consentimiento sexual. Exploran este concepto en estudios de caso, socio-dramas y análisis grupal.
1 El consentimiento significa estar de acuerdo en hacer algo. Dar el consentimiento sexual significa estar de acuerdo con tener relaciones sexuales. Todas las personas tienen derecho a dar o negar el consentimiento sexual. Todas las personas tienen la responsabilidad de respetar el derecho de su pareja a dar o negar tal consentimiento.

\section{La coerción sexual ocurre cuando alguien fuerza (o trata de forzar) a otra persona} para que participe en una actividad sexual en contra de su voluntad. En una situación coercitiva, una persona puede ser forzada físicamente a tener relaciones sexuales. O la persona puede sentir temor por las consecuencias sociales o físicas de rehusarse a tener relaciones sexuales no deseadas.

- Cualquier persona puede ser coaccionada para tener actividad sexual no deseada. Sin embargo, es más común que las niñas y las mujeres sean víctimas de coerción.

- Las personas pueden ser coaccionadas sexualmente de diferentes formas: por manipulación emocional, engaño, fuerza física o amenazas, intimidación e incentivos económicos, para nombrar unas cuantas.

- Las relaciones sexuales forzadas y la violación pueden suceder en cualquier parte (incluso en el hogar o dentro de las familias y en las relaciones íntimas, así como en entornos que normalmente se consideran seguros, como las escuelas e instituciones religiosas).

- La prevalencia de las relaciones sexuales forzadas es aún mayor en ciertas situaciones: durante la guerra, en campos de refugiados, en las prisiones, en el trabajo sexual y en situaciones de trata de seres humanos con fines de explotación sexual o esclavitud. [Ver hoja informativa sobre Trata de Seres Humanos con Fines de Explotación Sexual.]

- Acariciar el cuerpo de otra persona sin su consentimiento puede también ser una forma de coerción. Si alguien le toca de forma tal que le haga sentir incomodidad, usted tiene el derecho de pedir a esa persona que se detenga.

3 Independientemente de las circunstancias bajo las cuales ocurre, la coerción sexual puede tener serias consecuencias.

- La coerción sexual puede conducir a problemas emocionales como sentimientos de inseguridad, aislamiento y depresión severa. También puede conducir a lesiones físicas.

- Las relaciones sexuales bajo coerción tienen mayor probabilidad que las consensuales de resultar en un embarazo no planeado, una infección con VIH u otras infecciones de transmisión sexual. 


\section{PUNTOS PARA REFLEXIÓN}

¿Qué se requiere para que el consentimiento sea consciente y real?

¿Qué nivel de juicio emocional, madurez y capacidad necesita una persona para tomar decisiones informadas sobre el sexo?

¿Siempre se da cuenta la gente de que tiene el derecho de rehusarse a la actividad sexual?

¿Por qué algunas personas pueden necesitar tiempo adicional para poner en orden y expresar sus sentimientos?

¿Qué tan fácil es para la gente joven expresar sus deseos sexuales y asegurarse de que sus parejas puedan hacer lo mismo?

¿Qué tan consciente es el consentimiento si una persona desconoce la condición de VIH de su pareja?

Algunas personas - incluida la gente joven - tienen relaciones sexuales a cambio de dinero o regalos. ¿Es válido y consciente su consentimiento?

¿De qué forma pueden las drogas o el alcohol limitar el juicio o capacidad de una persona para tener claridad de mente al tomar decisiones sexuales?
- Algunas personas se incorporan al trabajo sexual por decisión propia. Otras venden sexo debido a que no pueden ganar el sustento de otra forma, o pueden verse forzadas a realizar trabajo sexual a través del engaño u otras presiones. [Ver hoja informativa sobre Trata de Seres Humanos con Fines de Explotación Sexual.]

- Algunas personas abogan por el derecho a participar en relaciones sexuales pagadas entre adultos que dan su consentimiento; y se oponen al estigma y a las consecuencias legales asociadas a ese trabajo.

7 La coerción sexual es siempre una violación de los derechos humanos, sin importar dónde, cuándo o cómo suceda. En muchos países, las y los educadores pueden proporcionar una lista de números telefónicos de emergencia y servicios de apoyo existentes para gente joven que haya experimentado coerción sexual. 


\section{creación de relaciones mutuamente respetuosas además de responsables}

1 Varios factores contribuyen a tener experiencias sexuales mutuamente satisfactorias, responsables y seguras. Esto se aplica durante toda su vida.

Estos factores incluyen:

- saber que usted y su pareja tienen los mismos derechos y cooperar para asegurar el respeto mutuo, el consentimiento y la responsabilidad;

- tratarse unos a otros como iguales; y como personas, no solamente como cuerpos;

- sentirse cómodos al comunicar lo que cada miembro de la pareja desea o no desea;

- respetar el derecho de la pareja de no hacer algo que le haga sentir incómoda o insegura;

- ser francos el uno con el otro;

- sentir intimidad;

- sentirse querido;

- usar formas seguras y efectivas para protegerse a sí mismo y a su pareja de embarazos no deseados e infecciones de transmisión sexual, incluido el VIH;

- esforzarse para protegerse a sí mismo y a su pareja de daño emocional;

- estar consciente de sus propios deseos y nivel de comodidad y los de su pareja; y

- ser capaz de dar y aceptar placer.

2 Todos nosotros podemos aprender a desarrollar un mayor respeto, responsabilidad y satisfacción en nuestras relaciones sexuales. 


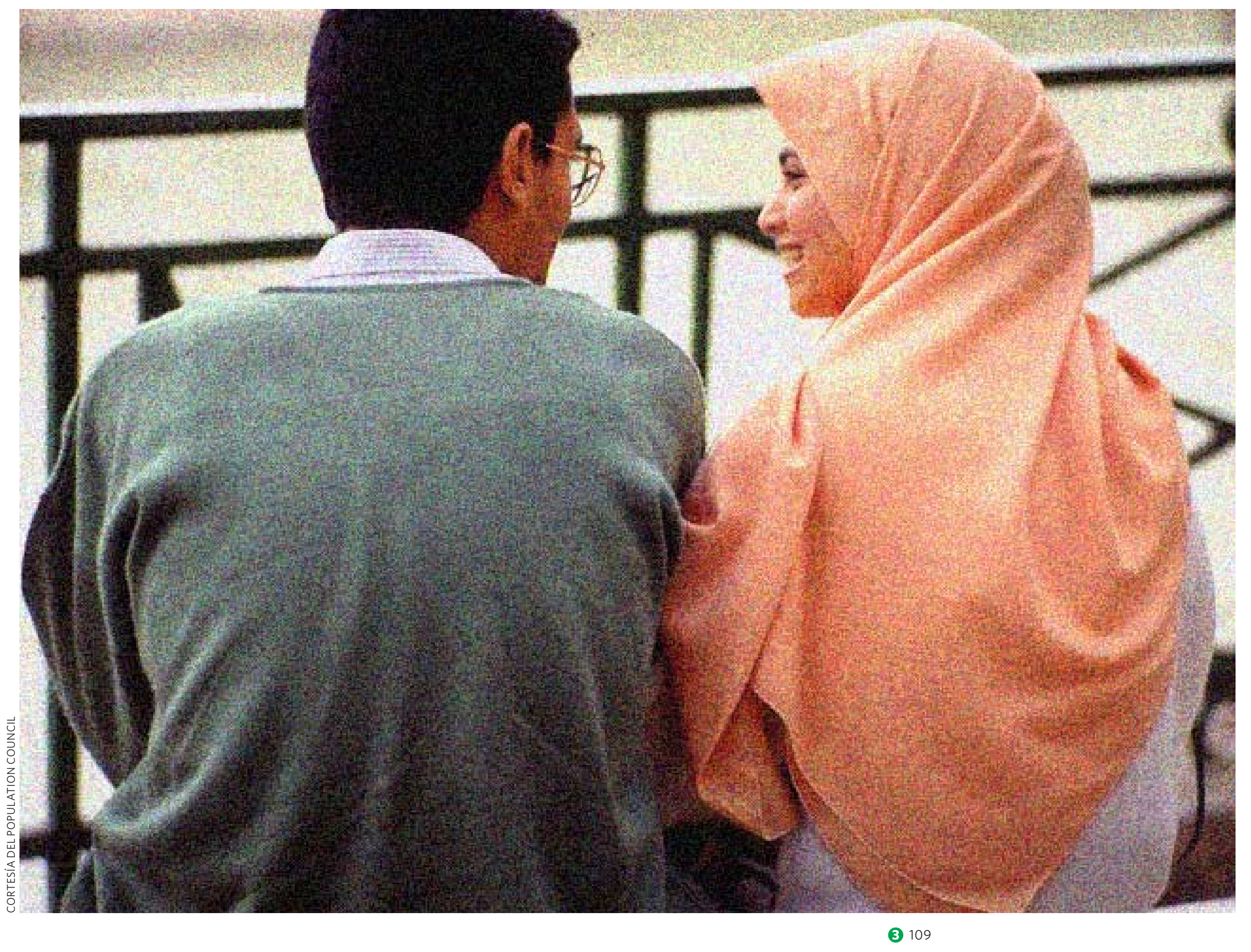




\section{preocupaciones sobre la función sexual}

1 Muchas personas desarrollan preocupaciones en algún momento acerca de si sus respuestas sexuales están funcionando de la forma en que debieran hacerlo.

- La mayoría de las preocupaciones sobre la función sexual se relacionan con los sentimientos y situación de una persona. Por ejemplo, las personas pueden preocuparse por las partes de su cuerpo, su atractivo o capacidad para "desempeñarse" sexualmente. Pueden haber aprendido actitudes negativas acerca del sexo o haber tenido experiencias sexuales desagradables. Pueden tener sentimientos negativos hacia su pareja. Pueden estar preocupadas por las ITS, el SIDA, o el embarazo, o pueden distraerse debido a la falta de privacidad. Pueden no saber acerca de la variación normal en la respuesta sexual o pueden no tener voluntad o no ser capaces de hablar acerca de sus necesidades sexuales.

- Con menor frecuencia, los problemas en la función sexual son causados por factores físicos, como la enfermedad, el alcohol, las drogas o los medicamentos.

2 Ciertas preocupaciones o problemas sexuales son bastante comunes en los hombres.

Estos incluyen:

- no poder tener o mantener una erección adecuada para el coito sexual. Casi todos los hombres experimentan esta preocupación en algún momento de su vida;

- eyacular demasiado pronto y sentir que la eyaculación no está bajo control;

- no poder tener un orgasmo o tomar más tiempo del deseado para llegar al clímax (tener un orgasmo); y

- no poder ayudar a su pareja para que llegue al orgasmo.

3 Ciertas preocupaciones o problemas sexuales son bastante comunes en las mujeres.

Estos incluyen:

- no poder tener un orgasmo o tomar más tiempo del deseado para llegar al clímax;

- no responder al estímulo sexual; y

- experimentar dolor persistente durante el coito (el cual puede ser causado por infecciones).

4 Muchas personas (sin importar su género o identidad sexual) experimentan períodos en los que carecen de interés en tener relaciones sexuales. El no tener un deseo similar por la relación sexual puede convertirse en una preocupación para ambos miembros de la pareja.

5 Comunicarse honesta y respetuosamente con la pareja puede restaurar la comodidad y el placer. Si una preocupación continúa vigente o interfiere con el placer sexual de una persona, hablar con un consejero profesional confiable puede ayudar. 


\title{
bienestar sexual y advocacy
}

1 Todas las personas deben tener la oportunidad de desarrollar la capacidad de tener una vida sexual segura, consensual y placentera, cuando estén listas para ello en sus vidas.

2 Nosotros podemos promover la salud, el placer y el respeto en nuestras relaciones sexuales.

Promover relaciones respetuosas y seguras implica, por ejemplo:

- aprender a respetar a nuestras parejas sexuales y expresar nuestras propias necesidades, lo que requiere habilidad y experiencia;

- comunicar nuestros sentimientos para ayudar a asegurar la salud, la comprensión y el placer mutuos; y

- esperar para tener sexo hasta que ambas personas en la pareja tengan la madurez y poder para negociar en beneficio propio y la habilidad para garantizar la comunicación, el respeto mutuo, el consentimiento, la seguridad y la comodidad.

3 En todo el mundo, quienes realizan trabajo de advocacy a favor de los derechos sexuales y reproductivos - grupos comunitarios, prestadores de servicios de salud, gente joven y otras personas - están promoviendo un mayor respeto, reciprocidad y consentimiento dentro de las relaciones sexuales. Algunos de los cambios hacia los que se está trabajando incluyen:

- mejor educación sexual;

- promoción de la igualdad de género;

- eliminación de leyes que penalizan las relaciones sexuales consensuales entre personas adultas, como la actividad sexual entre personas del mismo sexo;

- reconocimiento de los derechos sexuales de las personas que viven con discapacidades; y

- mejor acceso a los servicios de salud sexual y reproductiva, como el acceso a la anticoncepción y al aborto legal y seguro, así como a las pruebas confidenciales, la consejería y el tratamiento para el VIH.

\author{
VER EL LIBRO DE ACTIVIDADES \\ Actividad 26 \\ temas de actualidad \\ relacionados con las políticas \\ y respuestas personales \\ Las y los estudiantes seleccionan \\ una noticia que refleje el cambio \\ de normas sobre la sexualidad y \\ escriben una respuesta personal.
}




\section{conceptos básicos sobre sexualidad}

Las siguientes breves explicaciones pretenden ayudar a las y los usuarios con la aclaración de términos importantes relacionados con la sexualidad. Estos términos se utilizan en todo este documento. Las y los educadores de todo el mundo aportan su creatividad y sensibilidad a la tarea de adaptar estos conceptos en sus propios contextos culturales y políticos.

Bienestar sexual: un sentido de bienestar relacionado con la sexualidad y la vida sexual de una persona.

Bisexualidad: tener atracción o deseo, comportamiento o identidad tanto del mismo sexo como del otro sexo.

Coito: cópula sexual que con frecuencia se refiere a la penetración vaginal con el pene. El coito oral involucra a la boca en o sobre un órgano sexual de la pareja. El coito anal involucra la inserción del pene en el ano de la pareja.

Derechos sexuales y reproductivos: derechos humanos que se aplican a la vida y la salud sexual y reproductiva. Por ejemplo, incluyen si una persona tiene relaciones sexuales, con quién las tiene y bajo qué circunstancias; si lleva un embarazo a término; y el derecho a proteger el propio cuerpo de la violencia o coerción sexual.

Deseo sexual: un anhelo por la expresión sexual o un sentimiento de atracción sexual.

Diversidad sexual: la amplia variación en los deseos, identidades y comportamientos sexuales de las personas.

Función sexual: respuestas fisiológicas que son parte de la propia sexualidad. 
Heterosexualidad: sexualidad entre hombres y mujeres.

Homosexualidad: sexualidad entre personas del mismo sexo. En algunos entornos, la atracción al mismo o al otro sexo se llama orientación sexual, o se utiliza otro término; este documento usa los términos de identidad sexual y diversidad sexual para referirse a la amplia gama de expresiones sexuales, incluida la atracción a personas del mismo o del otro sexo.

Identidad sexual: forma en que las personas se identifican a sí mismas en términos de varios aspectos de su sexualidad, lo cual puede incluir sus preferencias y atracciones sexuales. Puede también incluir la clase de relaciones que quisieran formar. La identidad sexual de una persona puede o no ser lo mismo que su deseo o comportamiento sexual.

Intersexual: tener cromosomas, genitales y/o características sexuales secundarias que no son exclusivamente masculinos ni femeninos.

Normas sexuales: estándares sociales que dan forma a nuestra comprensión, actitudes y experiencias relacionadas con la sexualidad.

Sexualidad: forma en que las personas experimentan y se expresan como seres sexuales. Muchos factores contribuyen a los comportamientos, relaciones, sentimientos, identidad, deseos y actitudes sexuales de las personas. Uno de estos factores es la biología, especialmente por las hormonas sexuales. Otro factor es la personalidad y experiencia individual. Aún otro factor es la cultura, la cual influye en las actitudes, expectativas y experiencias de las personas relacionadas con la sexualidad. Las normas culturales también afectan las leyes y políticas sobre sexualidad. Todos estos factores interactúan a lo largo de la vida. 
REHACIONESTh

NHERPESONALs:

-

(1)

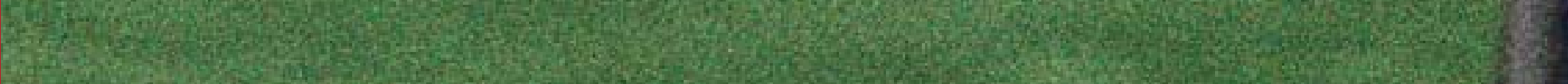
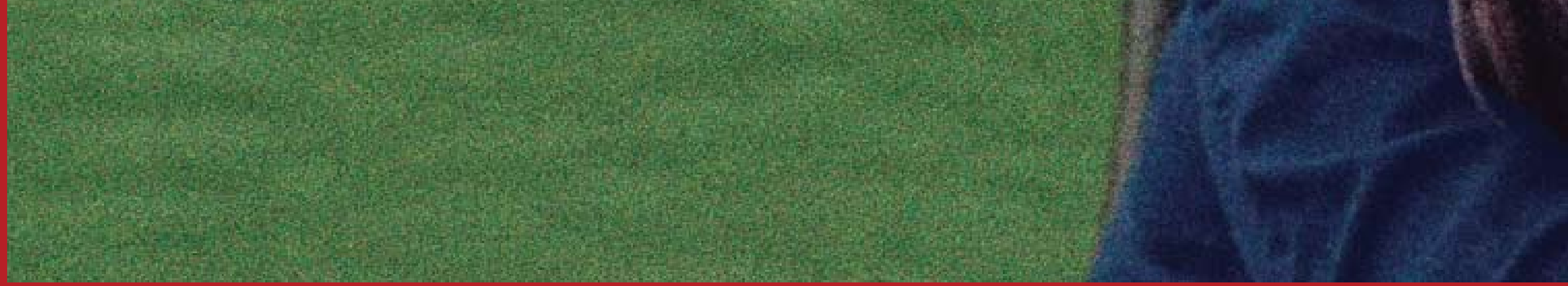


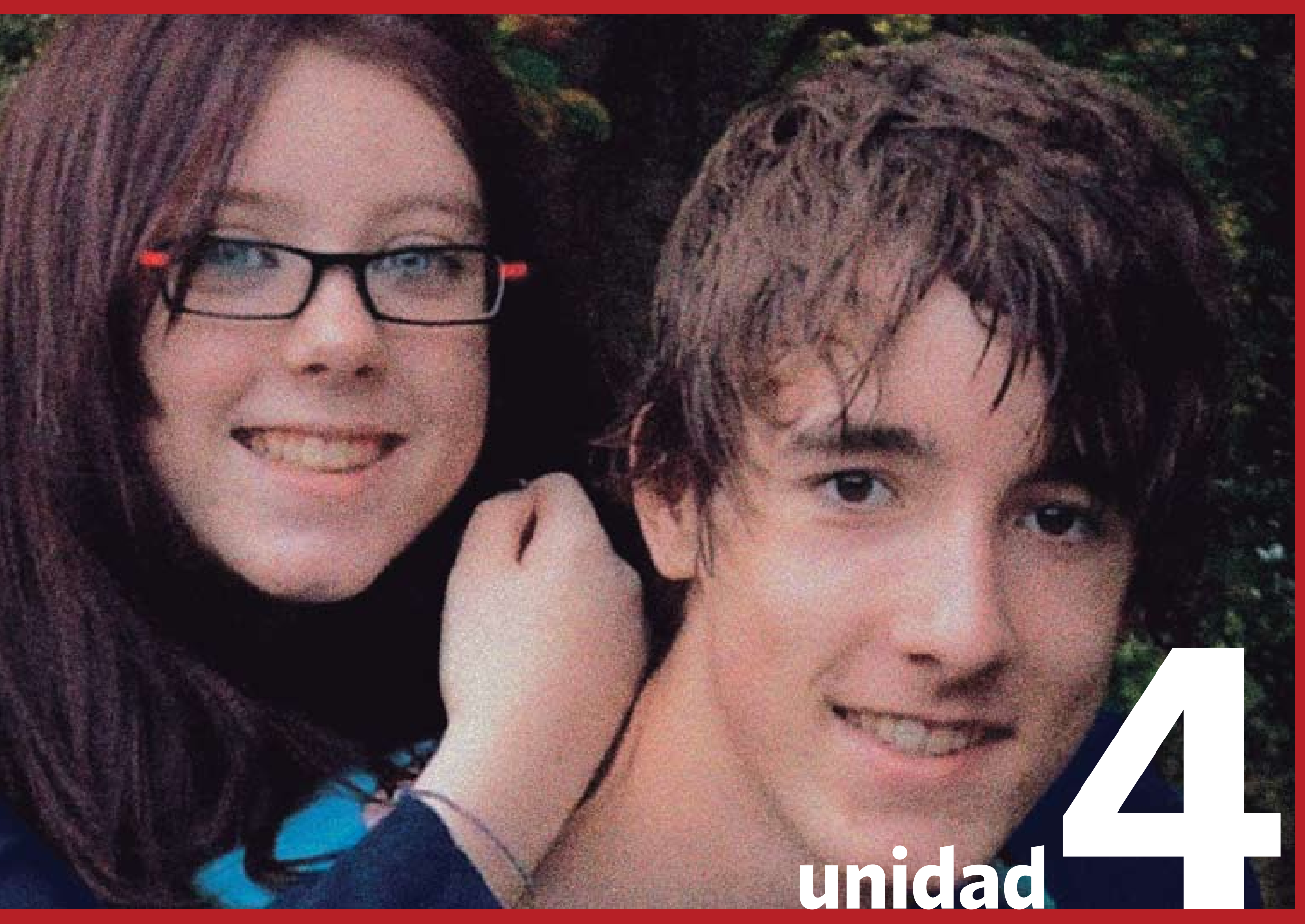




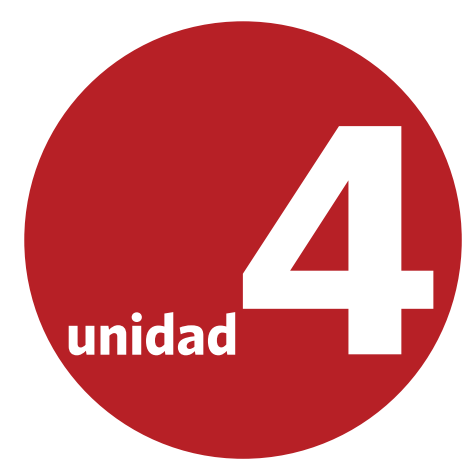

\section{visión general}

Al reflexionar sobre nuestras relaciones interpersonales, la mayoría de nosotros piensa en la personalidad o experiencia individual. Nuestras relaciones, sin embargo, también se ven influenciadas por la sociedad. Por ejemplo, las diferencias de poder entre las personas, las representaciones de las relaciones interpersonales en los medios, así como otros factores influyen fuertemente en nuestras ideas sobre las relaciones personales. Durante la adolescencia, la gente joven puede experimentar sentimientos diferentes, muchas veces intensos, conforme los aspectos de sus relaciones sufren un cambio dramático.

Esta unidad explora los diferentes tipos de relaciones que tienen las personas, incluidas las relaciones románticas o sexuales. Alienta a la gente joven a pensar acerca de las cualidades que buscan en las relaciones personales íntimas en sus propias vidas. 


\section{RELACIONES INTERPERSONALES}

Aunque la interacción personal involucra lo mejor y lo peor de la experiencia humana, las relaciones afectuosas dan significado a las vidas de mucha gente y representan gran parte de lo que es la vida.

Enfóquese primero en los diferentes tipos de relaciones que tienen las personas. Después, ponga énfasis en las relaciones románticas o íntimas.

La conexión entre maestros y estudiantes es también un tipo de relación interpersonal. Aunque las y los maestros tienen autoridad, los principios básicos de respeto y dignidad se aplican a la interacción maestroestudiante.

Valide el conocimiento de sus estudiantes: Toda persona tiene alguna experiencia acerca de las relaciones humanas.

Permita a las y los estudiantes compartir sus experiencias o mantenerlas en privado.

Invite a sus estudiantes a pensar acerca de la necesidad de respeto, compasión y derechos humanos en las relaciones con las personas que son $\mathrm{VIH}$-positivas. Estas relaciones pueden ocurrir en la escuela, en la comunidad, en la familia ampliada o en otra parte. Esta consideración es particularmente importante en entornos con una alta prevalencia de $\mathrm{VIH}$.

Esta unidad aborda temas acerca de los cuales la gente joven típicamente tiene muchas preguntas y sentimientos. Asigne suficiente tiempo para permitir ejercicios y un tratamiento amplio del tema. 


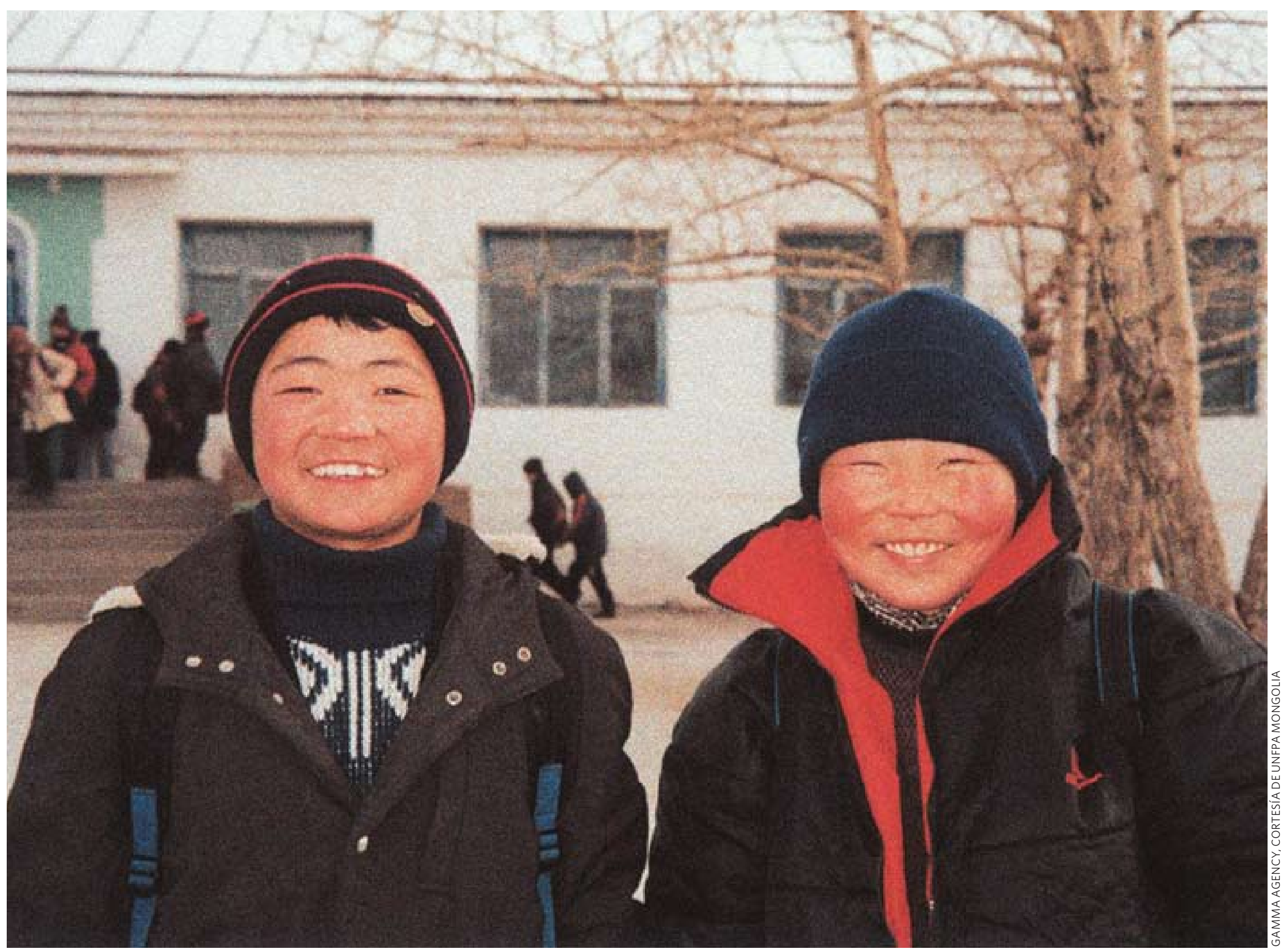




\section{RELACIONES INTERPERSONALES}

El material en esta unidad prepara a las y los estudiantes para:

\section{Objetivos cognoscitivos}

Describir el derecho básico a formar relaciones y el derecho a ser tratados con respeto y dignidad. Describir diferentes tipos de relaciones y estructuras familiares.

Describir dos factores personales y dos sociales o culturales que puedan contribuir a, o bloquear, las relaciones satisfactorias y mutuamente respetuosas.

Analizar en grupo los tipos de temas sobre los que la gente debe ser capaz de hablar con comodidad y madurez, con el fin de asegurar relaciones sexuales seguras, respetuosas y consensuales.

Analizar en grupo dos retos claves que muchas personas jóvenes enfrentan en las relaciones íntimas.

\section{Objetivos afectivos}

Reflexionar sobre las diferencias entre el amor y el apasionamiento, con ejemplos de sus propias vidas. Reflexionar sobre la naturaleza de sus relaciones y el tipo de relaciones que desean tener en sus propias vidas.

Reflexionar con sinceridad sobre su propio nivel de madurez y comodidad en la comunicación con una pareja para asegurar que las experiencias íntimas sean deseadas, seguras, respetuosas y placenteras.

Apreciar la importancia de conocer los propios derechos y responsabilidades; de tener habilidades de comunicación; y de tener apoyo personal o profesional para abordar o terminar una relación problemática.

Identificar lo que creen que son sus fuentes de fortaleza y debilidad, así como la forma en que incorporan esas percepciones en sus relaciones interpersonales.

[Para revisar objetivos relacionados basados en destrezas, ver la Unidad 5: Habilidades de comunicación y toma de decisiones.] 


\section{introducción a las relaciones interpersonales}

Las relaciones igualitarias [incluidas aquellas] entre la mujer y el hombre respecto de las relaciones sexuales y la reproducción, ... exigen el respeto y el consentimiento recíprocos y la voluntad de asumir conjuntamente la responsabilidad.... (Párrafo 96, Plataforma para la Acción FWCW, 1995).

1 Las relaciones interpersonales son asociaciones sociales, conexiones o afiliaciones entre dos o más personas.

- Para la mayoría de las personas, tener relaciones interpersonales es una parte importante de su felicidad.

- Las relaciones humanas pueden llenar varias necesidades emocionales, sociales, físicas, intelectuales y económicas.

- Nuestra cultura determina la forma en que vemos el mundo que nos rodea y las relaciones dentro de él. Las relaciones entre las personas cambian conforme cambia su cultura.

2 Toda persona en cada sociedad tiene muchas clases diferentes de relaciones.

- Estas incluyen los vínculos con miembros de la familia, amistades, colegas de trabajo, vecinos, conocidos, novios, novias, maestros, compañeros estudiantes y otras personas.

- Las relaciones interpersonales también varían en su calidad. Por ejemplo, las diferentes relaciones pueden caracterizarse por su mayor o menor franqueza, confianza, comunicación, intimidad, capacidad de compartir, poder, respeto, afecto y sentimientos.

- Las relaciones pueden estar o no centradas en torno a algún o algunos aspectos compartidos en común. Por ejemplo, las personas en las relaciones pueden ser vecinos; compañeros de clase; compañeros de trabajo; miembros del mismo club; feligreses de la misma iglesia, mezquita o templo; miembros de un grupo de apoyo a personas que viven con el SIDA; o personas usuarias de la misma red social en internet.

- Las personas expresan sus sentimientos hacia los demás de muchas maneras diferentes.

VER EL LIBRO DE ACTIVIDADES

\section{Actividad 27}

mis relaciones

Las y los estudiantes crean una representación visual de sus

relaciones.
3 Las personas pueden iniciar nuevas relaciones a lo largo de su vida. También, pueden terminar las relaciones. Algunas veces, una relación puede ser dañina para el bienestar de una o ambas personas. Las personas no están obligadas a permanecer en una relación. 


\section{relaciones en nuestras vidas}

1 A lo largo de sus vidas, las personas tienen varias relaciones personales, incluidas las relaciones amorosas. Para la mayoría de las personas hay importantes relaciones tempranas que se forman con miembros de sus familias. Las y los niños pequeños buscan amor incondicional en sus padres, en otros adultos confiables o en miembros de mayor edad en la familia.

- Las familias toman muchas formas. Los miembros de la familia pueden o no estar relacionados biológicamente.

- Una familia ampliada típicamente incluye a familiares que no son la familia inmediata; y puede incluir a personas que no están relacionadas biológicamente.

- Muchas familias incluyen a uno o más niños adoptados.

- Los miembros de la familia pueden vivir juntos en el mismo hogar o pueden estar separados, ya sea por decisión propia o por las circunstancias. Algunas circunstancias comunes que separan a las familias son: el trabajo, la migración, el servicio militar y la prisión. Estas situaciones pueden separar a los miembros de una familia por períodos largos o de manera permanente.

- En familias con hijos, las y los niños pueden vivir con dos padres (en una relación hombre o mujer o una del mismo sexo), con uno solo de los padres, con miembros de la familia ampliada o con tutores adultos.

- Algunos niños crecen sin una protección confiable de personas adultas, pero pueden ser criados por niños de mayor edad.

\section{Como todas las relaciones interpersonales, las relaciones familiares están cambiando.}

Por ejemplo:

- En muchas partes del mundo hay en la actualidad más mujeres que son jefas de familia, en comparación con el pasado.

- En muchos lugares, las actitudes sociales acerca de la paternidad están cambiando. Como resultado, cada vez más padres están construyendo relaciones estrechas con sus hijos y compartiendo la responsabilidad del cuidado infantil. Esto es especialmente cierto en los casos en que las mujeres están entrando a la fuerza de trabajo formal.

- En lugares en donde grandes cantidades de personas han muerto como consecuencia del SIDA, guerra u otras razones, muchos niños huérfanos viven con otros familiares o en orfanatos.

- Conforme las actitudes culturales en muchos lugares se vuelven más tolerantes para aceptar diversos arreglos familiares, más parejas del mismo sexo están viviendo abiertamente y muchas están criando hijos. Estos padres pueden traer hijos de matrimonios previos, pueden adoptar o pueden usar tecnologías de reproducción asistida como la inseminación artificial o subrogación.

3 La amistad es uno de los tipos más importantes de las relaciones interpersonales.

\section{PUNTOS PARA REFLEXIÓN}

¿Por qué formamos amistades?

¿Qué cualidades definen la amistad? ¿Confianza? ¿Afecto? ¿Qué más?

En algunas culturas, muchas veces la gente joven forma amistades agradables, no sexuales con personas del otro sexo. En otras culturas, lo hacen con menos frecuencia. ¿Cómo podemos explicar esta variación?

¿Qué podemos ganar al establecer una amistad con alguien que tenga una formación o pertenezca a un grupo diferente? 
VER EL LIBRO DE ACTIVIDADES Actividad 28

¿qué está pasando entre estas dos personas?

Las y los estudiantes leen estudios de caso de relaciones caracterizadas por desigualdades sociales; identifican las

desigualdades y conversan sobre su efecto en las relaciones.

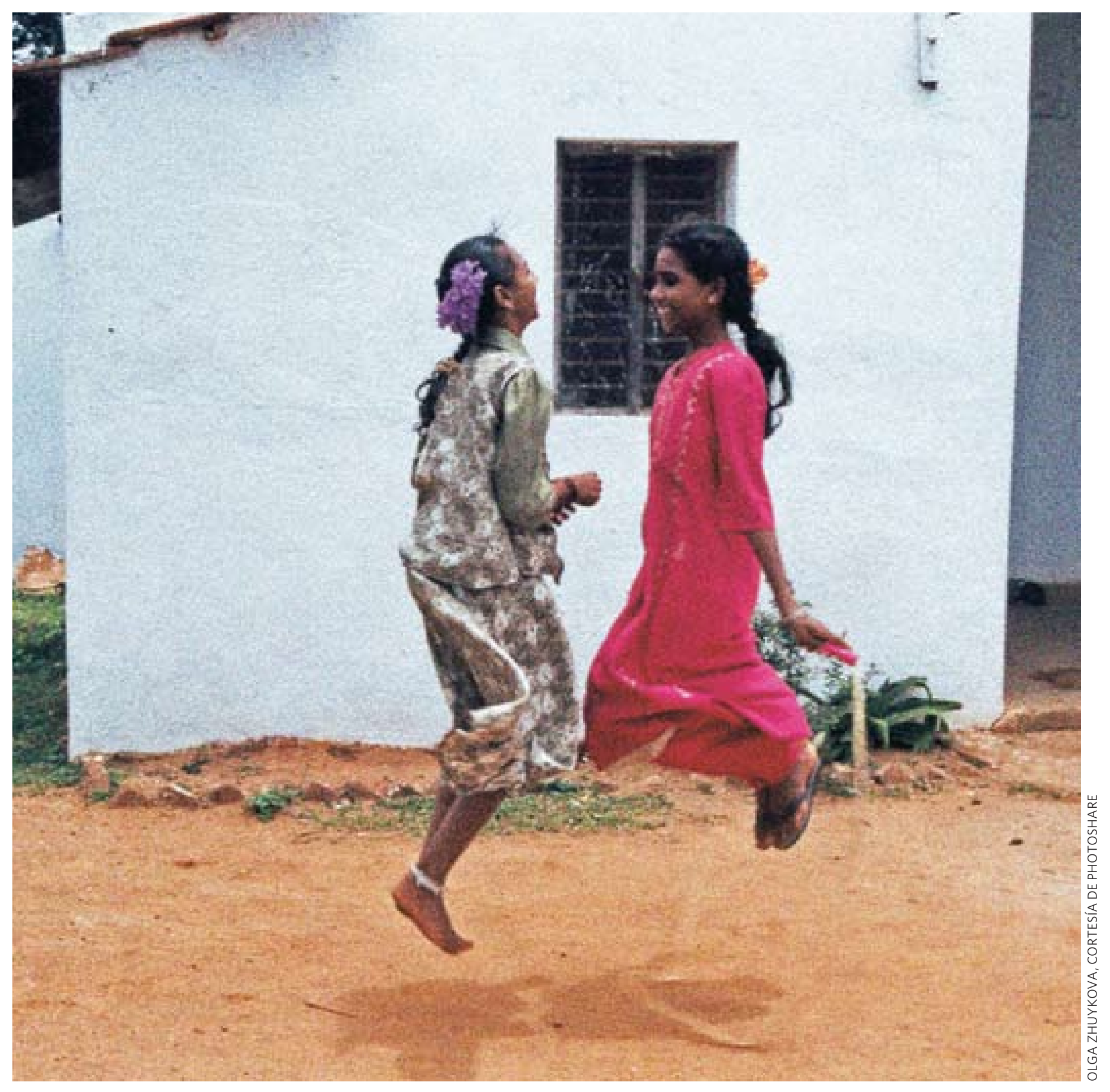

(4) 122 


\section{¿cómo puede nuestra relación ser más respetuosa y satisfactoria?}

1 Todos nosotros deseamos relaciones que sean satisfactorias y mutuamente respetuosas.

2 Ciertas cualidades personales ayudan a construir relaciones satisfactorias y mutuamente respetuosas.

- respeto por uno mismo, así como conciencia y comodidad con los propios sentimientos y valores;

- sensibilidad hacia los sentimientos de otras personas y respeto por su dignidad y derechos;

- expectativas compartidas;

- franqueza y autenticidad;

- buenas habilidades de comunicación [ver Unidad 5 para más información sobre lo que esto implica];

- "dar y recibir" (reciprocidad); y

- cuidarse, pasar tiempo y prestarse atención mutuamente.

3 El apoyo de la sociedad en general puede también promover relaciones positivas. Sin embargo, las desigualdades sociales pueden minar el respeto mutuo y la comodidad en las relaciones entre las personas.

- Los padres, líderes religiosos y los medios pueden enseñar a la gente joven a respetarse unos a otros como iguales - sin importar su raza, religión, origen étnico, género, condición económica, capacidad física, condición de VIH, u otras categorías.

- Las escuelas y organizaciones comunitarias pueden reunir a gente joven de diferentes procedencias para que no crezcan aisladas y sin conocer a otras personas que tienen otra formación o condición social.

- Las escuelas y las familias pueden enseñar a la gente joven a darse cuenta cuando las situaciones no son iguales y a comprender la forma en que las diferencias de poder entre las personas pueden deteriorar una relación satisfactoria y mutuamente respetuosa.

\section{PUNTOS PARA REFLEXIÓN}

¿Pueden ustedes recordar una situación en la cual una persona se considerara superior a otras, o que estuviera en una posición de maltrato hacia otra persona?

¿Qué clase de experiencias han ustedes compartido con alguien que sea diferente, y qué les enseñaron estas experiencias? 


\section{relaciones románticas: cortejo y citas}

1 El cortejo y las citas se refieren a la interacción social con otras personas que podrían convertirse en parejas románticas o sexuales.

2 Las normas y prácticas acerca del cortejo y las citas varían enormemente en todo el mundo.

- En muchos entornos, el cortejo o citas son la costumbre. Sin embargo, no todas las culturas practican el cortejo y las citas y no toda la gente corteja o hace citas.

- En entornos en donde las personas no pueden hacer citas en persona, pueden encontrar otras formas de comunicarse como a través de internet.

- En lugares en donde es costumbre el arreglo de los matrimonios, las personas pueden casarse sin que haya habido de por medio un cortejo o citas. En tales entornos, los padres (o la comunidad) pueden arreglar el matrimonio o identificar una pareja potencial para el matrimonio de su hija o hijo.

- Muchas personas, aunque no todas, cuyos matrimonios son arreglados pueden llegar a sentir que han crecido juntos y que tienen un matrimonio amoroso.

\section{3 ¿Qué ofrecen el cortejo y las citas?}

- Dan oportunidad a que la gente desarrolle sus habilidades interpersonales. Estas habilidades incluyen reconocer, respetar y expresar sus propios sentimientos; reconocer los sentimientos de otras personas; y desarrollar una comprensión de lo que valoran, gozan y aprecian en otras personas.

- Dan oportunidad a las personas de tener compañía y nuevas experiencias.

- Dan oportunidad a las personas de conocer gradualmente a una potencial pareja romántica o sexual.

\section{4 ¿A qué edad empiezan las personas a tener citas o cortejar?}

- La edad a la que la gente joven comienza a tener citas varía ampliamente de persona a persona y a través de culturas y sociedades.

- La edad a la que los padres permiten a la gente joven comenzar a tener citas o cortejar varía ampliamente — tanto dentro de las comunidades como a través de las comunidades y culturas.

- Muchas personas adultas también tienen citas. 


\section{5 ¿Las personas a quién cortejan, citan o con quién "salen"?}

- Con frecuencia, pero no siempre, una persona cita a alguien de su misma edad. En algunos entornos, los hombres adultos buscan a niñas como parejas para salir. Esta discrepancia de edad contribuye, en ocasiones, a una división desigual de poder en la relación.

- Muchas veces, pero no siempre, las personas citan a alguien de su mismo grupo social. El algunos casos, una persona puede citar a alguien de diferente raza, origen étnico, religión, nivel socioeconómico o casta. Algunas familias y comunidades, pero no todas, se sienten cómodas y apoyan tales relaciones interpersonales.

- Las personas pueden salir con alguien del mismo sexo o del otro sexo.

\section{6 ¿Cómo comienzan las citas y el cortejo?}

- Las personas se reúnen en formas diferentes, lo que incluye reunirse a través del trabajo, escuela, familia, amistades mutuas, redes sociales, en la comunidad, en internet o de otras formas.

- En muchos contextos heterosexuales, se espera que los niños y los hombres inicien la cita. En algunos lugares, sin embargo, esta convención se ha ido relajando y las niñas y mujeres también inician las citas. Muchas personas se sienten nerviosas por invitar a alguien a salir en una primera cita.

\section{7 ¿Qué hace la gente en una cita o como parte del cortejo?}

- Lo que la gente hace en las citas varía. Por ejemplo, pueden sentarse a platicar, pasear a pie o en bicicleta, compartir una taza de café o té, ver un filme, asistir a un evento o fiesta en la comunidad, o visitar a amistades o a miembros de sus familias.

- Dos personas pueden involucrarse en estas actividades por su propia cuenta, con un grupo de amigos más amplio, o ser acompañadas por miembros de la familia o un chaperón. Estas costumbres tienen la tendencia a ser determinadas por las normas locales.

- Algunas personas cortejan, incluso por extensos períodos de tiempo, a través de internet u otros medios de comunicación.

- Las personas pueden sentirse relajadas, emocionadas, nerviosas o ansiosas por el hecho de tener una cita con una persona en particular.

- Las personas pueden salir solamente una vez o pueden continuar teniendo citas o cortejándose durante muchos años.

- El cortejo puede ser una oportunidad para desarrollar confianza y amistad. Por ejemplo, la gente joven puede compartir sus valores, esperanzas y sueños, así como experiencias difíciles o preocupaciones que estén enfrentando. 


\section{8 ¿Quién paga los gastos en una cita?}

- Una cita no tiene que suponer gasto de dinero. Cuando si hay gasto, las prácticas varían. Muchas personas comparten los costos de la cita. Algunas veces se espera que el joven o el hombre pague por los gastos de la cita. Algunas veces la persona que cuenta con mayores recursos es la que paga.

- El arreglo financiero debe ser aceptable para ambas partes. Los desembolsos de dinero por una persona no requieren que la otra persona tenga que cumplir con obligaciones incómodas o no deseadas, incluida la actividad sexual.

\section{9 ¿El contacto sexual o físico íntimo es parte de las citas?}

- Algunas veces, las personas que participan en una cita encuentran que se sienten atraídas físicamente y pueden desear un contacto sexual, lo que puede incluir tomarse de las manos, besarse, acariciarse o tener otro tipo de actividad íntima.

- En un contexto de confianza, reciprocidad y respeto, tales experiencias pueden ser maravillosas y emocionantes. Pueden ofrecer oportunidades para que la gente joven aprenda acerca de sus propios sentimientos y respuestas sexuales.

- Para muchas personas, compartir una experiencia sexual siempre implica afecto, intimidad o amor. Para otras, el amor no siempre es parte de la relación sexual. Aún en ausencia de amor, los miembros de una pareja sexual pueden compartir confianza, respeto, cariño y placer.

- Algunas personas se sienten cómodas anticipando la relación sexual. Pueden así asegurarse de tener condones u otros anticonceptivos con anticipación. (Los condones tanto masculinos como femeninos pueden prevenir el embarazo y proteger contra el VIH y otras infecciones.) Otras personas pueden tener relaciones sexuales sin haberlas planeado o conversado con su pareja. En estos casos pueden no haber pensado en tener lista alguna forma de protección.

- Hablar con la pareja sobre la posibilidad de tener relaciones sexuales es importante para asegurar el consentimiento mutuo. Tales conversaciones pueden aumentar la comodidad de ambos miembros de la pareja y ayudar a garantizar su seguridad. [Ver Unidad 5, página 150.]

\section{0 ¿Qué hacer si se le presiona para tener relaciones sexuales durante la cita o el cortejo?}

- En ningún caso o por ninguna razón una persona está obligada a tener contacto sexual no deseado. Esto es así aún si la otra persona gastó dinero en la cita, o si las citas o el cortejo han durado por largo tiempo.

- Desafortunadamente, la coerción sexual es común en el contexto de las citas e incluso en algunos eventos sociales grupales. Esto es un grave problema social que algunas veces se denomina "violación por acompañante". La violación por acompañante es aún más frecuente cuando la cita conlleva un consumo excesivo de alcohol, cuando hay poca o nula responsabilidad social en el comportamiento del acompañante, o cuando no hay amigos confiables cerca a quienes recurrir. La gente joven debe aprender dónde y cómo puede ocurrir la violación por acompañante en sus propias comunidades. 


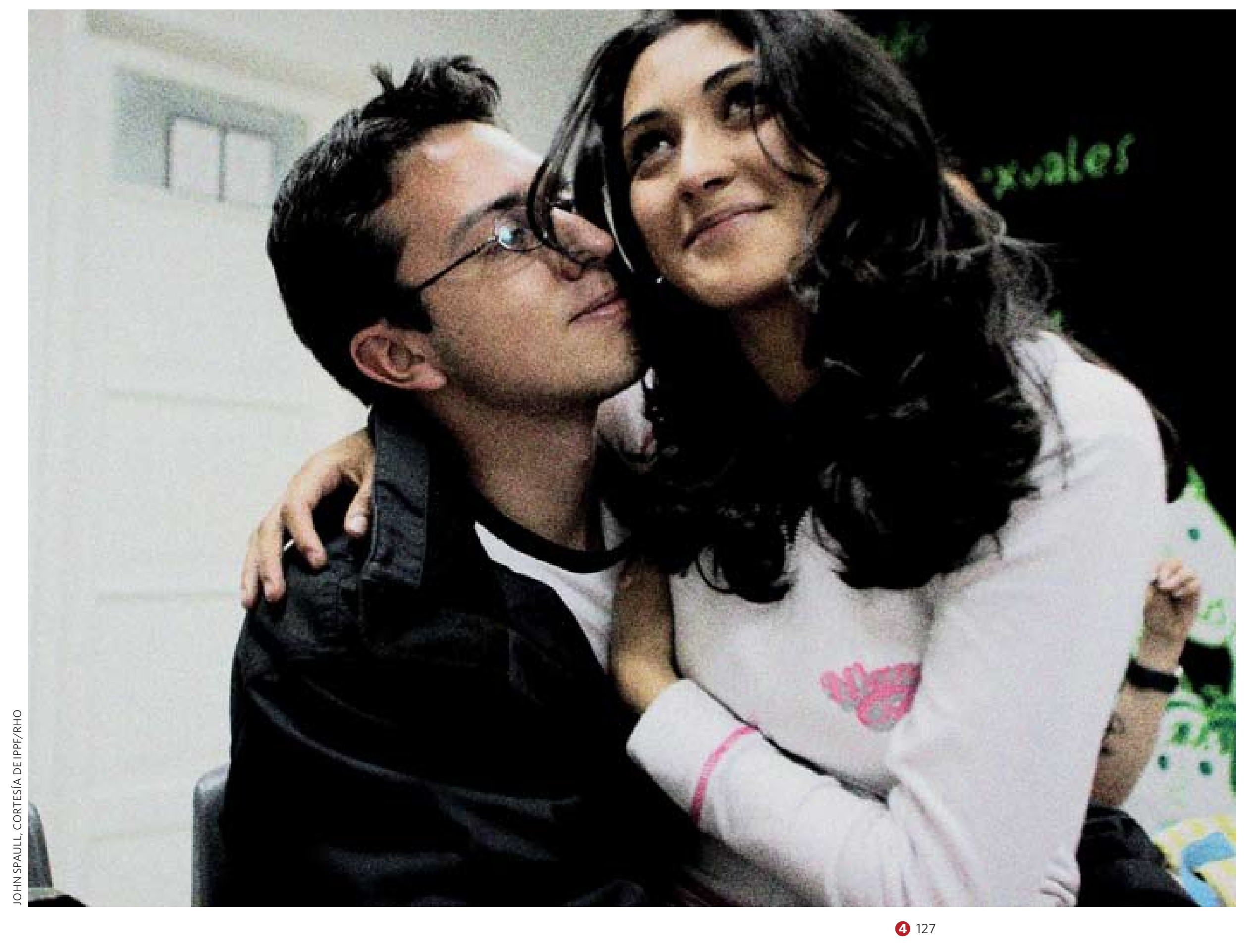




\section{romance: ¿̇qué es enamorarse? ¿qué es "amor verdadero"? ¿qué hay de los celos?}

1 Las ideas sobre "romance" y "amor" varían en diferentes entornos.

\section{PUNTOS PARA REFLEXIÓN}

¿Cuáles son los principales mensajes sobre el romance en los cuentos de hadas para niños? ¿En los videos musicales?

¿Qué tan realistas son esos mensajes? ¿Qué clase de expectativas imponen estos mensajes en los hombres jóvenes? ¿En las mujeres jóvenes?

¿Qué tan necesario es el amor romántico para la felicidad en la vida?
2 Típicamente, "enamorarse" implica sentimientos de pasión, atracción sexual y excitación. Algunas veces, este sentimiento se denomina "fascinación", "romance", o "apasionamiento" por alguna persona.

- Generalmente, enamorarse es una experiencia emocionante.

- Algunas veces (aunque no siempre) una relación romántica implica sentimientos de compromiso e intimidad.

- Enamorarse puede ser una experiencia de una sola persona; la persona objeto del amor puede no sentir lo mismo.

- Todo el mundo puede enamorarse. Las personas adultas, así como las adolescentes, se enamoran.

- Las personas pueden enamorarse solamente una vez, más de una vez o muchas veces en sus vidas.

$\ominus 3$ Las y los niños crecen asimilando muchos mensajes sobre el romance y el amor.

4 ¿Que es el "verdadero amor"? Amar a alguien es preocuparse profundamente por esa persona y estar comprometido con su bienestar y felicidad. Amar y ser amado puede ser fuente de un profundo gozo y significado en la vida.

- El amor es una de las emociones más poderosas que experimentan las personas. Ha inspirado grandes obras de arte, literarias y musicales.

- Hay muchas maneras diferentes de amar a alguien.

- Las personas pueden sentir amor por miembros de su familia inmediata o ampliada, por amigos cercanos y por sus parejas o cónyuge del mismo o del otro sexo.

- El término "verdadero amor" o "amor real" con frecuencia se refiere a un lazo afectivo con la pareja íntima que ha trascendido la etapa de "fascinación" o apasionamiento.

- Explicar los sentimientos de afecto, amor romántico, deseo sexual y "amor verdadero" es, con frecuencia, difícil y confuso.

- Todo el mundo recibe mensajes de su cultura acerca de lo que es el amor, a quién debemos (o no debemos) amar y cómo debemos expresar (o no expresar) nuestro amor. 
5 Cuando la gente siente que una relación valiosa está amenazada, puede ponerse celosa.

- Los celos (en cualquier tipo de relación, incluidas las románticas) se refieren a sentimientos de envidia, posesión, vulnerabilidad, ira y resentimiento.

- La mayoría de las personas tienen sentimientos de celos en algún momento en sus vidas.

- En las relaciones románticas, las personas pueden sentirse celosas de una o un rival romántico real o imaginario. Sin embargo, una persona puede también sentir que su relación está amenazada por los compromisos de la pareja para con la familia, amistades o trabajo.

\section{Algunas personas expresan los celos con amenazas, violencia o mediante un comportamiento controlador o manipulador.}

- Tales comportamientos no son amor y nunca son expresiones de amor.

- La violencia y la coerción son demostraciones de poder sobre otra persona. Siempre violan los derechos humanos de la persona contra quienes son usados, sin importar si son expresiones de celos o de otros sentimientos.

- Tanto la persona que siente celos como su pareja pueden beneficiarse al hablar franca y respetuosamente acerca de sus sentimientos mutuos. Cada una de estas personas puede también beneficiarse al conversar con alguna amistad, persona adulta o consejera que sea confiable.

\footnotetext{
VER EL LIBRO DE ACTIVIDADES Actividad 29

¿es amor?

Las y los estudiantes distinguen

el amor de las emociones

relacionadas.
} 


\section{actividad sexual en las relaciones}

1 ¿Qué ofrece una relación sexual satisfactoria a las personas?

- Las relaciones sexuales satisfactorias pueden unir a las personas, ser placenteras y enriquecer la vida.

- Las relaciones sexuales deben ser seguras, deseables y placenteras.

- Nunca una persona está obligada a tener contacto sexual no deseado.

\section{PUNTOS PARA REFLEXIÓN}

Aún cuando estén excitadas sexualmente, con frecuencia las personas tienen sentimientos encontrados acerca de tener contacto sexual íntimo. Pueden no estar seguras de lo que esto conlleva. ¿Qué podría pasar si las personas reconocieran sus sentimientos encontrados y sus cuestionamientos acerca de las relaciones sexuales?
2 ¿Siempre sabe una persona si él o ella desea tener contacto sexual íntimo?

3 Para una persona que es sexualmente activa, ¿qué factores contribuyen a tener una relación sexual que sea emocionalmente satisfactoria, responsable y segura para ambos miembros de la pareja?

Además de los factores que contribuyen a cualquier relación interpersonal (ver página 123), las relaciones sexuales en particular generalmente son más cómodas, satisfactorias y seguras cuando ambos miembros de la pareja:

- sienten intimidad y cariño; y que no son simplemente un cuerpo por conveniencia;

- aseguran el consentimiento, respeto y responsabilidad mutuos;

- pueden dar y aceptar placer sexual;

- se sienten cómodos comunicando lo que desean o no desean hacer;

- respetan el derecho de la otra persona de no hacer algo que le haga sentir incómoda;

- comparten la responsabilidad por el uso de métodos seguros y efectivos para prevenir el embarazo no deseado y las infecciones de transmisión sexual, incluido el VIH;

- conocen su propia condición de VIH (y de otras ITS) y la de su pareja; y

- hablan acerca de si tendrán o no parejas sexuales fuera de su relación. Cuando las personas tienen solamente una pareja sexual, su relación se describe como monógama o "basada en la fidelidad". 


\section{4 ¿De qué formas la gente joven algunas veces se siente presionada por su novio o novia} para tener relaciones sexuales?

Algunas de las razones por las que las personas tienen relaciones sexuales que no desean incluyen:

- ceder a la presión de sus pares;

- para probar amor o tratar de ganar compromiso en una relación;

- para evitar herir los sentimientos o el ego de la otra persona;

- porque las citas o el cortejo han ocurrido por algún tiempo;

- porque previamente hayan acordado tener relaciones sexuales, aún cuando uno de los miembros de la pareja haya cambiado posteriormente de parecer;

- debido a que la otra persona esté en una posición de poder, jerarquía o autoridad (por ejemplo, por la edad, popularidad social, recursos o género);

- debido a la presión de los miembros de la familia, personas mayores o líderes de la comunidad;

- con el fin de obtener dinero o regalos; y

- debido a que el alcohol o las drogas hayan limitado el juicio o la capacidad de resistir a una insinuación sexual no deseada.

Desafortunadamente, aún en las relaciones establecidas, muchas personas experimentan coerción sexual, abuso o violencia. Cualquier persona puede ser sujeta a tal tipo de abuso, aunque más frecuentemente las niñas y las mujeres son las víctimas. El abuso sexual es dañino y siempre es incorrecto. Nunca es culpa de la víctima. Las relaciones sexuales bajo coerción también están asociadas con un mayor riesgo de transmisión de VIH. [Ver la Unidad 2, páginas 70-71 y la Unidad 3, páginas 106-107.]

\section{Desarrollar un alto nivel de comodidad, habilidades de comunicación y madurez en las} relaciones sexuales es un proceso aprendido y toma tiempo.

- Debido a que muchas personas jóvenes inician sus relaciones sexuales mientras están todavía creciendo en estas áreas, tienen una particular propensión a sentirse incómodas y afligidas; ansiosas o avergonzadas; y temerosas de contraer el VIH o de embarazarse.

- Los niños y hombres, en particular, pueden sentirse presionados a "desempeñarse" sexualmente. Pueden sentir que no pueden admitir que les faltan conocimientos o experiencia. Por su parte, las niñas y mujeres pueden sentir que no es apropiado para ellas hablar de temas como el uso del condón o sobre sus propios deseos sexuales.

- La práctica y el estímulo pueden ayudar a la gente joven a superar tales presiones y aprender a comunicarse con mayor confianza.

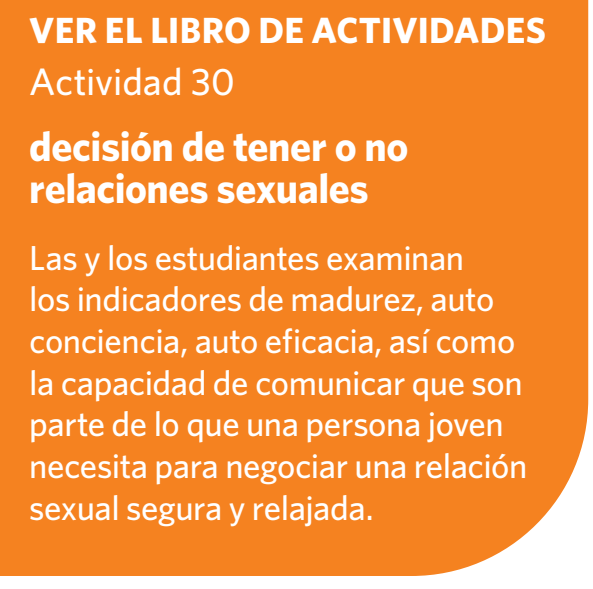

VER EL LIBRO DE ACTIVIDADES Actividad 30

decisión de tener o no relaciones sexuales

Ss indicadores de madurez, auto la capacidad de comunicar que son parte de lo que una persona joven sexual segura y relajada. 


\section{relaciones íntimas a largo plazo}

1 Las personas forman diferentes tipos de relaciones a largo plazo, comprometidas y amorosas.

- La mayoría de la gente es educada con la expectativa de que formará una relación con una pareja del otro sexo, se casará con esa persona, tendrán hijos y permanecerán en ese matrimonio por el resto de sus vidas.

- La realidad para muchos millones de personas, sin embargo, es mucho más compleja. Las personas pueden formar muchas formas diferentes de relaciones comprometidas a largo plazo. Pueden tener más de una relación a largo plazo que sea satisfactoria. O pueden mantenerse solteras, ya sea por las circunstancias o por decisión propia. Pueden formar relaciones hombre-mujer o relaciones del mismo sexo.

- Ya sea por decisión propia o debido a circunstancias ajenas a su control, las personas pueden: vivir juntas parte o todo el tiempo; acordar ser monógamos mutuamente o tener otras parejas sexuales; criar hijos por sí solas o con otros miembros de la familia; casarse; y/o hacer compromisos mutuos de por vida.

\section{PUNTOS PARA REFLEXIÓN}

Varios factores contribuyen a la compatibilidad a largo plazo entre las personas.

¿Qué tan importante son para usted los valores compartidos? ¿La amistad? ¿La compatibilidad intelectual? ¿La atracción sexual? ¿Un sentido compartido de responsabilidad? ¿Una capacidad para comunicarse? ¿Franqueza? ¿Compromiso compartido? ¿Armonía con parientes políticos y la familia ampliada? ¿Vida espiritual o religiosa compartida? ¿Respeto mutuo por los derechos de la otra persona?

\section{Una relación íntima a largo plazo y comprometida puede desarrollarse como resultado} de diferentes circunstancias. Por ejemplo, puede surgir de un apasionamiento, amistad o un arreglo entre las familias.

\section{La naturaleza del matrimonio y de las relaciones íntimas a largo plazo varía de lugar a} lugar y a través del tiempo.

- En muchos lugares, una proporción significativa de parejas forma uniones fuera del matrimonio.

- En muchas sociedades, las personas encuentran sus propias parejas íntimas o cónyuges. En otros lugares, las familias eligen una cónyuge para su hija o hijo - alguien que consideran será una pareja conveniente, o que fortalecerá las estructuras de parentesco social, o ambos.

- La mayoría de las sociedades prohíben estar casado con más de una persona a la vez. En donde existe la poligamia, virtualmente en todos los casos implica que un hombre tenga múltiples esposas y no lo contrario.

- Aunque las tasas de matrimonio infantil van en descenso, esta costumbre continúa afectando a millones de niñas en todo el mundo.

- En algunas sociedades, las mujeres están eligiendo casarse a una mayor edad o no casarse del todo.

- En algunos entornos, los hombres se están casando a edades mayores que lo hacían en el pasado, porque no pueden sostener a una familia. 
4 En todo el mundo algunas parejas están creando matrimonios o relaciones a largo plazo con base en la igualdad de género y los derechos humanos. Están haciendo esto aún cuando esa decisión desafíen a las normas locales.

[Ver Unidad 2, páginas 60-61.]

- En muchos entornos, la apertura está aumentando en actitudes hacia el matrimonio en personas con diferentes antecedentes (por ejemplo, de diferentes religiones, razas o castas).

- Algunas sociedades están discutiendo, o votando sobre el derecho de las parejas del mismo sexo a casarse o formar uniones civiles que conllevan muchos de los mismos derechos legales y las responsabilidades del matrimonio.

5 Muchas personas que forman parte de relaciones a largo plazo tienen preocupación acerca de la transmisión del VIH a su pareja o cónyuge. Un miembro de la pareja puede tener la infección con VIH mientras que el otro no, o alguno de ellos o ambos pueden tener parejas sexuales fuera de la relación. La información, el acceso a los condones, así como las pruebas confidenciales y la consejería son elementos de importancia crítica para ayudar a las parejas a desarrollar estrategias de prevención de la transmisión.

[Ver Unidad 7, Parte 1.]

\section{VER EL LIBRO DE ACTIVIDADES Actividad 31 \\ cómo vivimos juntos en las relaciones \\ Las y los estudiantes consideran si están cambiando las costumbres relacionadas con el matrimonio y la estructura familiar; y cómo lo están haciendo.}

VER EL LIBRO DE ACTIVIDADES Actividad 32

qué es lo que estoy buscando

Las y los estudiantes hacen una lista de las cualidades que buscarían en una pareja de largo plazo y analizan sus respuestas desde una perspectiva de género. Las y los estudiantes consolidan lo que han aprendido en una carta o canción dedicada a una pareja futura imaginaria. 


\section{dificultades en las relaciones}

1 Todas las relaciones - incluso las que son estables y felices - tienen períodos de dificultad o momentos de frustración. Sin embargo, algunas relaciones son más profundas y crónicamente problemáticas que otras.

Algunos signos de una relación problemática pueden incluir:

- un serio desequilibrio en el respeto por la dignidad y derechos mutuos;

- sentimientos de falta de autenticidad acerca de uno mismo ("no poder ser uno mismo" en una relación);

- sentimientos permanentes de soledad y aislamiento;

- ausencia de valores compartidos o intereses comunes;

- sentimiento permanente de desprecio hacia la pareja;

- episodios que implican violencia física, sexual o psicológica, o la amenaza de ese tipo de violencia; y

- una relación externa inesperada de la pareja.

Resolver problemas en una forma productiva y no violenta requiere esfuerzo y habilidad. [Ver Unidad 5.]

VER EL LIBRO DE ACTIVIDADES

\section{Actividad 33}

problemas amorosos

Las y los estudiantes completan relatos acerca de relaciones

que muestran signos de alguna

situación problemática y

reflexionan en lo que les haría

terminar con una relación. 


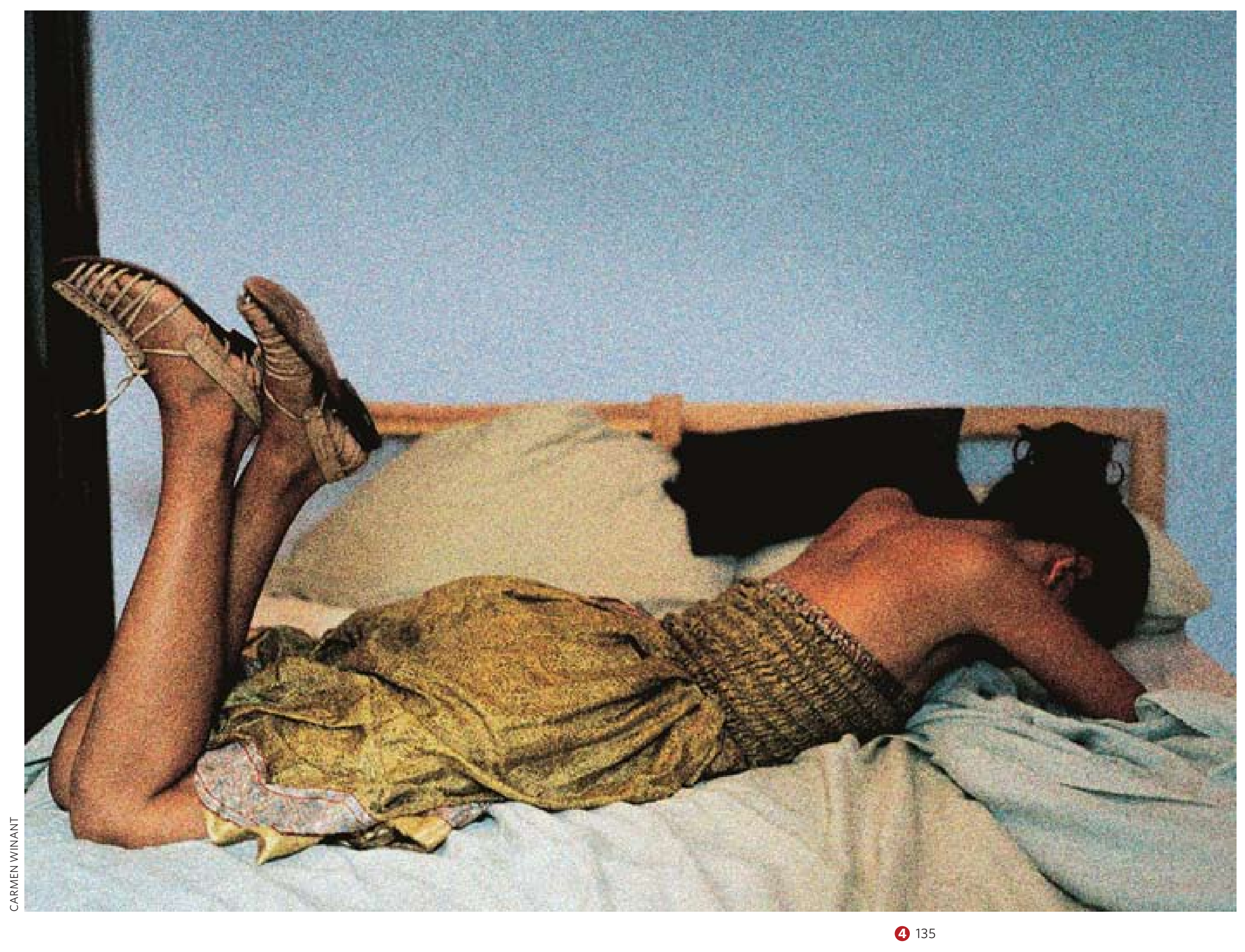




\section{término de una relación}

1 Nadie debe ser forzado a formar parte de una relación, a casarse o a permanecer en una relación.

- El fin de una relación no siempre es por consentimiento mutuo. Aún para el matrimonio, la mayoría de los países reconocen el derecho de un miembro de la pareja a terminar con una relación.

- Las personas deben tener derecho de buscar un divorcio. Las personas pueden buscar el divorcio por muchas razones. Por ejemplo, pueden ser parte de un matrimonio en el cual sus derechos están siendo violados. Pueden haber tratado sin éxito de resolver graves incompatibilidades por un largo período de tiempo.

- El fin de una relación puede estar asociado con fuertes sentimientos de tristeza, dolor, soledad, ira y fracaso. También, puede traer consigo sentimientos de alivio o felicidad. 


\section{las normas sobre las relaciones están cambiando}

1 Las actitudes y normas sobre las relaciones interpersonales están cambiando constantemente.

2 Tomamos decisiones todos los días acerca de cómo nos relacionamos con otras personas. Esas decisiones crean y recrean el significado de las relaciones en nuestras vidas.

3 En la actualidad, las personas conversan con sus amistades y familiares acerca de lo que significa una relación respetuosa y segura para ellas.

Por ejemplo:

- Muchas personas hablan con miembros de su familia y amistades acerca de las relaciones no tradicionales, como son las relaciones entre personas del mismo sexo o las relaciones entre personas de diferente religión, casta o raza.

- Muchas personas jóvenes instan a sus amigas y hermanas a evitar a los hombres mayores o "amantes adinerados" que ofrecen dinero o regalos a cambio de relaciones sexuales.

- Una conversación respetuosa y honesta puede también ayudar a que las personas reflexionen en sus propios prejuicios.

4 Muchas personas actúan públicamente para promover relaciones más seguras y más respetuosas en todos los niveles de la sociedad.

Por ejemplo:

- Las personas jóvenes están desempeñando roles importantes para elevar el nivel de conciencia acerca de temas como la violación por acompañante y el estigma relacionado con la infección con VIH.

- Las campañas para mejorar el acceso a medicamentos y servicios para personas con VIH están permitiendo que esas personas vivan más tiempo y les están dando esperanza y confianza para desarrollar y alimentar sus relaciones personales en el largo plazo.

- Muchos miles de hombres se han unido a campañas para terminar con la violencia contra las mujeres y para construir relaciones interpersonales más pacíficas y armoniosas.

[Ver la Unidad 8 para consultar antecedentes y pautas más detalladas orientadas a tomar medidas en la propia vida o comunidad.] 


\section{HABILIDADES DE COMUNICACIÓN Y TOMA DE DECISIONES}




\section{visión general}

El saber expresarse para ser comprendido y ser capaz de comprender lo que otras personas están tratando de decir, son habilidades importantes y empoderadoras. Estas habilidades pueden ayudarle a desarrollar relaciones basadas en la comprensión y satisfacción mutuas. Pueden ayudar a que las personas resuelvan conflictos de manera respetuosa y sin violencia.

Algunas personas encuentran que su posición en una comunidad influye en su capacidad para expresar sus necesidades, deseos y sentimientos a otra persona. Esto puede afectar también su capacidad para convertir sus decisiones en acciones. Todas las personas pueden aprender a comunicarse de manera efectiva.

Esta unidad explora las dificultades que frecuentemente la gente joven enfrenta al comunicarse y tomar decisiones relacionadas con su sexualidad. Enseña habilidades relacionadas y proporciona oportunidades para fortalecer tales habilidades. 


\section{HABILIDADES DE COMUNICACIÓN Y TOMA DE DECISIONES}

Haga parejas de estudiantes para que aprendan y practiquen habilidades de comunicación entre sí; los socio-dramas son también útiles y divertidos.

Cuando enseñe habilidades de comunicación y toma de decisiones, asegúrese de tener varios ejemplos concretos que se relacionen con las vidas de sus estudiantes.

La mayoría de las y los estudiantes necesitan habilidades adicionales, práctica y apoyo cuando aprenden a comunicar sus sentimientos acerca del sexo y la sexualidad sin avergonzarse. Los temas que pueden ser especialmente sensibles incluyen: comunicar la propia condición de $\mathrm{VIH}$, compartir lo que les hace sentir placer y lo que no es placentero, o decidir si comunicar o no la propia experiencia de atracción hacia el mismo sexo y cómo hacerlo.

El modelaje de habilidades de comunicación, como la escucha activa y las respuestas libres de críticas, es una parte importante de la enseñanza de esas habilidades.

Recuerde la importancia de la comunicación no verbal. Permanezca consciente de su propio lenguaje corporal. El cuerpo de una persona puede enviar un mensaje que demuestre estar en conflicto con lo que la persona está diciendo.

Cree un ambiente seguro en el que todas y todos sus estudiantes puedan comunicarse abiertamente, incluso las y los estudiantes que típicamente se reprimen en frente de otros. Sin embargo, evite presionar a alguien para que se exprese sobre algún tema personal o sensible. 


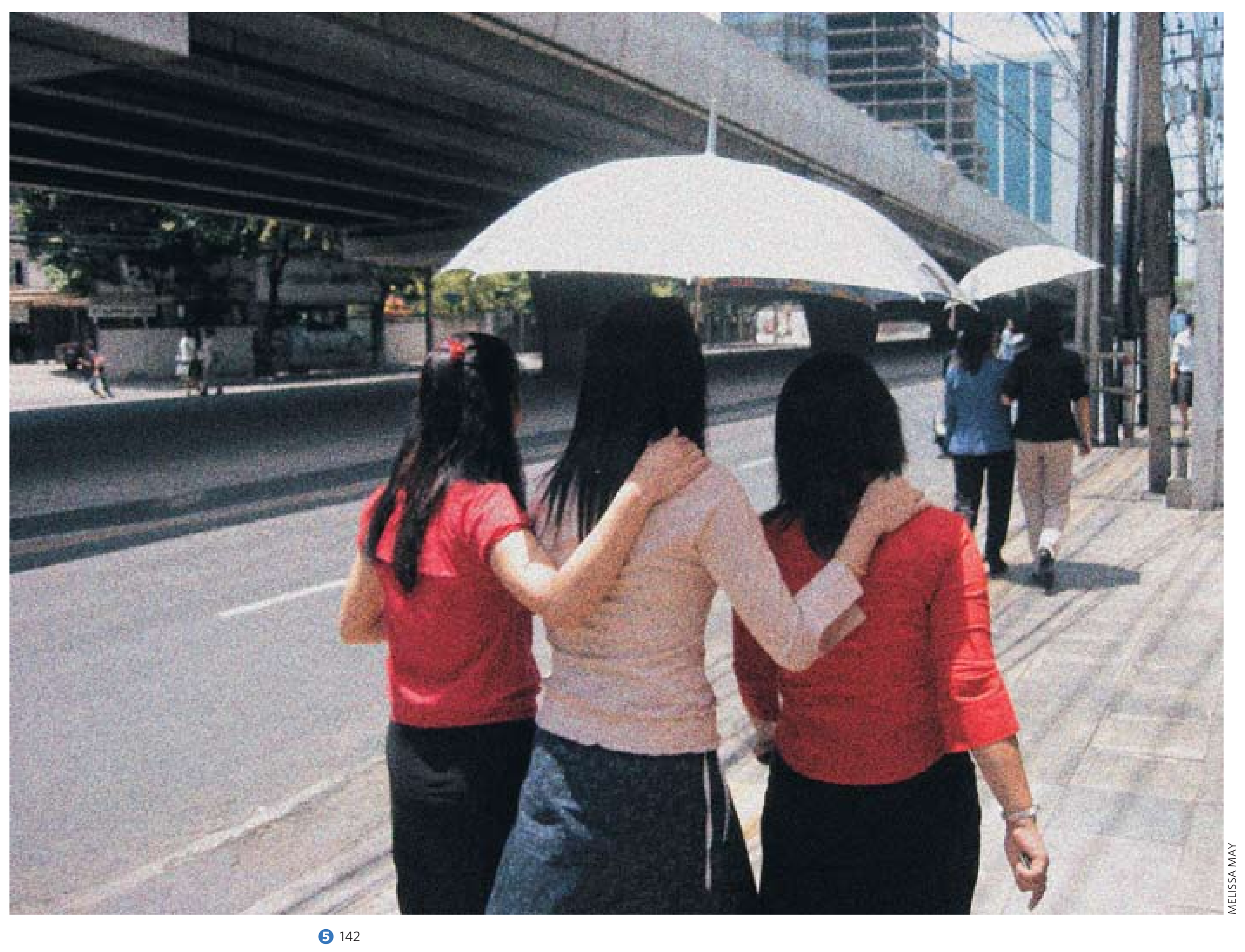




\section{HABILIDADES DE COMUNICACIÓN Y TOMA DE DECISIONES}

El material en esta unidad prepara a las y los estudiantes para:

\section{Objetivos cognoscitivos}

Explicar por qué puede ser difícil hablar sobre sexualidad o VIH.

Identificar una situación común de toma de decisiones sexuales que pueda ser incómoda para alguien que carezca de habilidades adecuadas de comunicación o toma de decisiones.

\section{Objetivos afectivos}

Valorar la importancia de las buenas habilidades de comunicación para las relaciones interpersonales.

Reflexionar con franqueza sobre su propio nivel de madurez y comodidad al comunicarse con una pareja o para asegurar que las experiencias íntimas sean deseadas, seguras, respetuosas y placenteras.

Valorar por qué es difícil para muchas personas jóvenes el comunicar clara y asertivamente que no desean tener relaciones sexuales.

\section{Objetivos basados en destrezas}

Demostrar el uso de al menos tres habilidades básicas de comunicación y de al menos tres comportamientos que pueden impedir una clara comunicación.

Demostrar una mayor capacidad para comunicarse claramente en una conversación sobre si ambos miembros de la pareja desean tener realmente actividad física íntima.

Demostrar una mayor capacidad de comunicarse claramente en una conversación sobre cómo protegerse contra las infecciones (incluido el VIH) y el embarazo no deseado.

Demostrar comprensión de los conceptos básicos en la toma de decisiones. 


\section{factores que afectan la comunicación}

1 Saber cómo expresarse de tal forma que usted sea comprendido y pueda comprender lo que otras personas están tratando de decir, son habilidades importantes y empoderadoras.

- Estas habilidades pueden ayudarle a desarrollar relaciones que estén basadas en una comprensión y satisfacción mutuas.

- Estas habilidades pueden ayudar a las personas a resolver conflictos de manera respetuosa y sin violencia.

- Estas habilidades pueden ayudarle a sentirse bien acerca de sí mismo y de sus relaciones.

\section{Las personas tienen diferentes estilos y habilidades para la comunicación.}

- Las diferentes culturas varían en términos de su tradición oral y expresiva.

- Los estilos de comunicación también dependen del temperamento individual de la persona y del estilo de comunicación que él o ella aprendió desde su niñez.

- Las normas de género con frecuencia afectan la capacidad y el estilo de comunicación de la persona. Hombres y mujeres pueden comunicarse en formas diferentes.

- Fortalecer las habilidades de comunicación personal puede ayudar a las personas a transmitir con claridad sus opiniones, necesidades y sentimientos.

- Las personas pueden desarrollar la capacidad de comunicarse efectiva y cómodamente a través de las culturas y de otras divisiones.

\section{PUNTOS PARA REFLEXIÓN}

En una conversación entre una persona adinerada y una persona de una clase o casta socioeconómica más baja, ¿quién es probable que se sienta más libre de expresar sus ideas y sentimientos? ¿Quién es más probable que se sienta con mayor libertad en una conversación entre un hombre y una mujer?

¿Cómo podemos asegurarnos de que las necesidades, sentimientos y derecho a comunicarse de una persona son respetados sin importar su condición social?
- 3 Si se percibe que una persona tiene menor "poder social" o condición social que otra, esta percepción puede afectar profundamente su capacidad y estilo en la comunicación.

4 La mayoría de las personas pueden aprender habilidades efectivas de comunicación. Con práctica, todo el mundo puede comunicarse más efectivamente. 


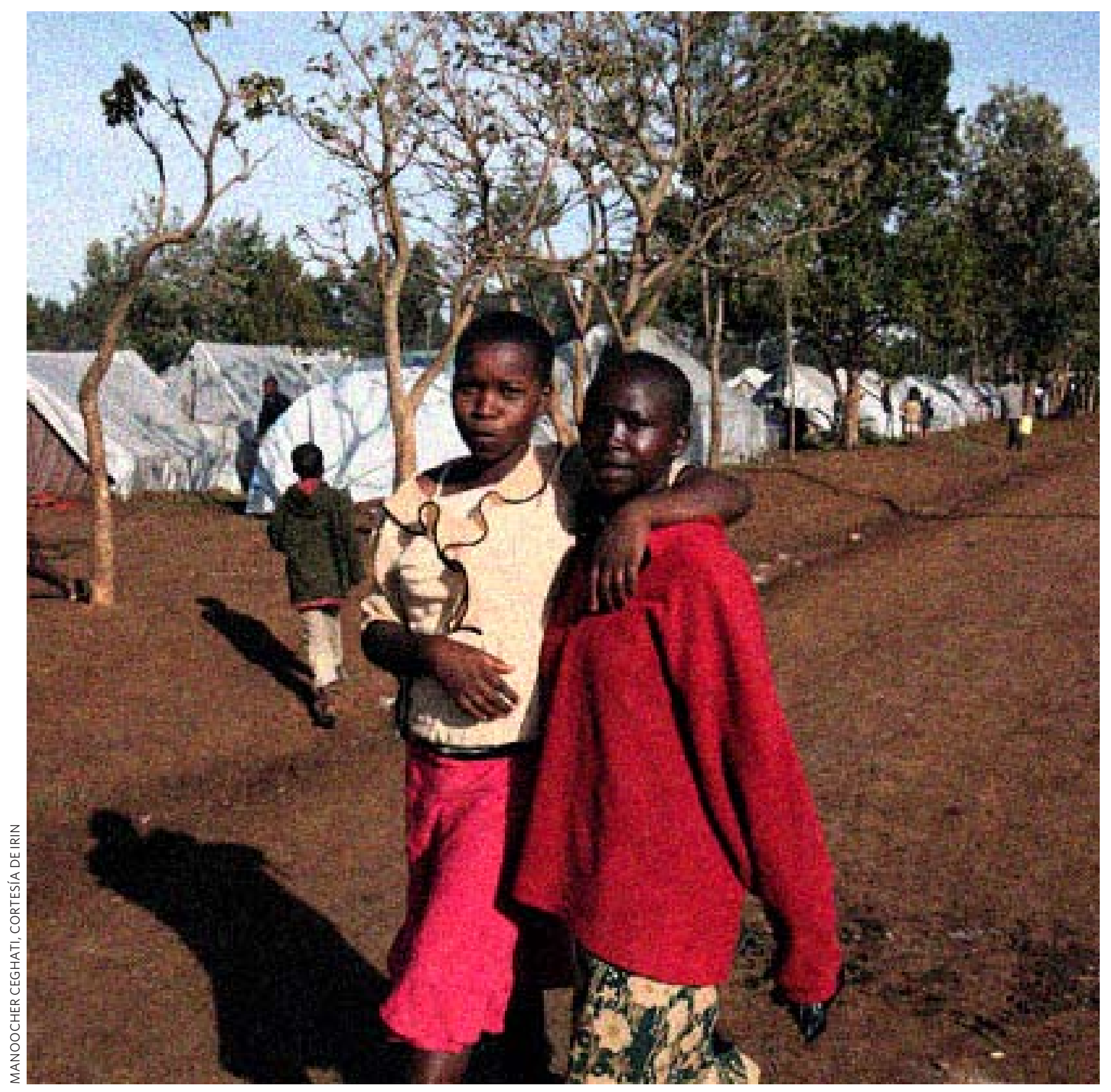

VER EL LIBRO DE ACTIVIDADES Actividad 34

éyo dije eso? diferentes estilos de comunicación

Las y los estudiantes examinan formas alternativas de responder verbalmente en una situación incómoda y discernir entre la comunicación agresiva, asertiva y pasiva. 


\section{sugerencias para una comunicación efectiva}

1 Una comunicación clara ocurre cuando el mensaje que el emisor intenta transmitir es el mismo que el mensaje que el receptor comprende.

- Las personas se comunican tanto verbal como no verbalmente.

- Es importante verificar que su mensaje haya sido entendido correctamente, especialmente si involucra un tema difícil o emocional.

2 En cada situación, uno de los comportamientos más importantes para la buena comunicación es escuchar bien y con respeto. Sin embargo, las normas culturales influyen en el tipo de comunicación que se considera apropiado.

3 La escucha activa y libre de críticas puede aumentar la comunicación.

Cuando usted está escuchando es útil:

- tratar de comprender a la otra persona o personas;

- decir cosas que validen lo que la otra persona está diciendo, como "puedo comprender cómo te sientes" o "buen punto";

- hacer contacto visual;

- dar indicaciones positivas no verbales, como una sonrisa, asentir con la cabeza o dar una palmada en la espalda; y

- solicitar que se aclare algún punto.

VER EL LIBRO DE ACTIVIDADES

\section{Actividad 35}

escucha activa

Las y los estudiantes demuestran comportamientos que aumentan (o perjudican) la comunicación. 
4 Algunos comportamientos específicos pueden aumentar la comunicación cuando uno habla.

Algunos comportamientos constructivos comunes incluyen:

- plantear los propios sentimientos y empezar las frases con "yo" en vez de "tú";

- reconocer que todas las personas tienen derecho a sus sentimientos y opiniones;

- evitar ser demasiado autoritario, crítico o controlador;

- plantear tan claramente como sea posible lo que uno desea o lo que no desea; y

- ayudar a identificar posibles soluciones a los problemas.

5 Muchos comportamientos pueden perjudicar la comunicación.

\section{PUNTOS PARA REFLEXIÓN}

Cuando está usted tratando de comunicarse, ¿cómo se siente:

Ser interrumpido o no escuchado?

Ser criticado, apodado o etiquetado?

Ser juzgado o que se le haga sentir culpable?

Percibir que la otra persona está

tratando de controlar la conversación?

Recibir mensajes negativos no verbales, como que le miren con el ceño fruncido? 


\section{estilos de comunicación directos versus indirectos}

VER EL LIBRO DE ACTIVIDADES Actividad 36

práctica de la comunicación asertiva

Las y los estudiantes revisan los comportamientos asertivos, conversan sobre las implicaciones culturales y practican usando comunicación asertiva en situaciones en donde se abusa de los derechos.

VER EL LIBRO DE ACTIVIDADES Actividad 37

cinco pasos para comunicarse sobre un conflicto

Las y los estudiantes aprenden y practican un modelo de cinco pasos para comunicar sobre un conflicto interpersonal con claridad y respeto.
1 Algunas personas tienden a comunicarse de una forma que es directa y firme. Otras, tienden a comunicarse en formas que son indirectas.

2 La comunicación directa y firme puede ser verbal o no verbal, pero generalmente envía un mensaje claro.

Por ejemplo:

- Una persona que se comunica asertivamente expresa sus sentimientos o pensamientos de una forma franca.

- Una persona puede usar "enunciados yo" que expresen sus sentimientos y pensamientos (por ejemplo, "yo me siento mal cuando me hablas de ese modo" o "yo me siento feliz de que me acompañaras a la clínica de salud").

- Una persona puede hacer contacto visual o usar mensajes no verbales para comunicarse directamente.

3 La comunicación indirecta puede ser también verbal o no verbal, pero con frecuencia envía un mensaje menos específico o menos definido.

Por ejemplo:.

- Una persona puede evitar el uso de expresiones específicas de su propia opinión o sentimientos (por ejemplo, "escuché que uno puede quedar embarazada la primera vez", en lugar de "rehuso tener sexo si no usas un condón").

- Una persona puede evitar completar la frase o hacer contacto visual.

\section{Algunas veces, saber cuál es la mejor forma de expresarse - directa o indirectamente}

- es difícil.

- Una persona que se comunica indirectamente puede estar siguiendo normas culturales sobre cortesía, condición social o expectativas sobre roles de género. Es importante comprender cómo reafirmarse uno mismo de manera efectiva en la propia cultura.

- La comunicación indirecta no siempre puede ser clara para quien escucha o recibe el mensaje.

- Algunas veces, las personas están en situaciones en las que no sienten estar siendo escuchadas. Puede ser necesario que practiquen para poder expresarse más clara, directa y repetidamente que de costumbre.

- Comunicarse directa y firmemente no es lo mismo que ser agresivo. Una persona puede comunicarse clara y directamente, a la vez que respeta los sentimientos y pensamientos de otras personas. 


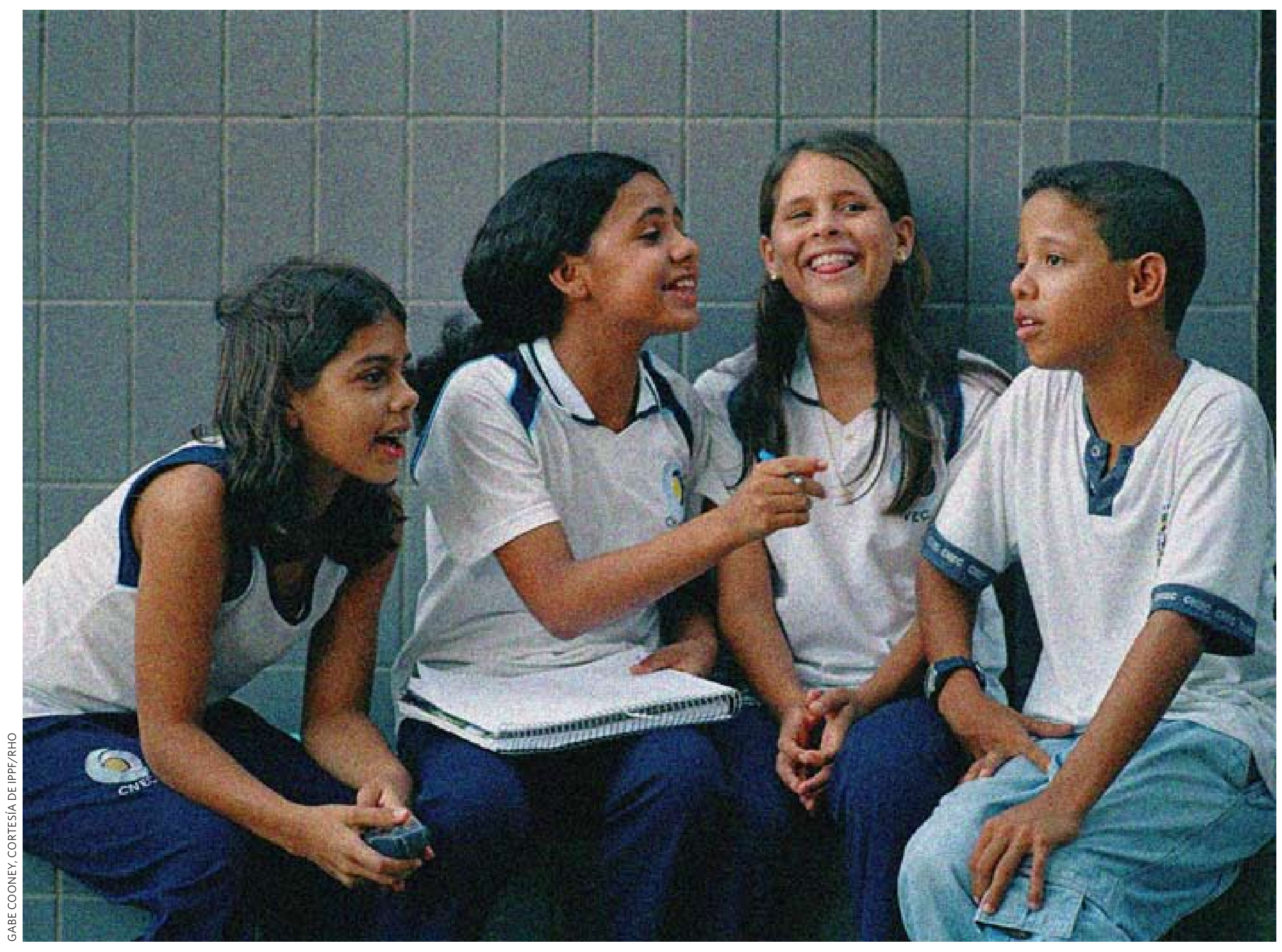




\section{conversación con su pareja sobre temas de sexo y salud sexual}

1 La comunicación es una parte importante de una relación sexual.

2 La comunicación con una pareja sexual es importante con el propósito de asegurar que ambas personas están otorgando su consentimiento para participar en la actividad sexual.

3 La comunicación efectiva puede ayudar a la gente a proteger el bienestar propio y el de su(s) pareja(s).

Esta protección incluye:

- protegerse contra las infecciones de transmisión sexual, incluido el VIH;

- protegerse contra el embarazo no deseado; y

- reducir la probabilidad de un conflicto que pudiera conducir a la violencia.

4 La comunicación puede también aumentar la confianza y placer mutuos.

5 Las comunicaciones son importantes para aclarar las expectativas y los límites.

Tales expectativas y límites pueden relacionarse con:

- los sentimientos;

- el intercambio de dinero o bienes materiales; u

VER EL LIBRO DE ACTIVIDADES - otros factores.

6 Las normas de género con frecuencia afectan la forma en que las personas se comunican - o no se comunican - respecto al sexo.

7 Todo el mundo puede aprender a comunicarse cómoda y efectivamente acerca de la sexualidad. iLa práctica ayuda! 


\section{toma de decisiones}

Una parte importante de crecer es aprender a incorporar el buen juicio en la toma de decisiones. Generalmente, seguir ciertos pasos ayuda a las personas a tomar decisiones con las que quedan más satisfechas. Estos pasos incluyen:

Paso 1: Considerar todas las opciones.

- Para muchas decisiones hay opciones en las que no hemos pensado.

- Otras personas pueden ayudar a identificar más opciones.

Paso 2: Identificar cuidadosamente los beneficios y desventajas de cada opción.

- Incluya el daño potencial de cada opción para sí misma o para otras personas.

- Escriba una lista de las consecuencias potenciales de cada opción.

Paso 3: Cuando sea apropiado, buscar información o asesoría de la gente en la que usted confía.

Paso 4: Tomar una decisión tentativa.

- Considere si su decisión podrá cambiarse posteriormente con facilidad o con dificultad.

\section{PUNTOS PARA REFLEXIÓN}

Muchas decisiones relacionadas con el sexo pueden ser complicadas. Imagine tener que considerar detenidamente estas decisiones:

si tener o no relaciones sexuales;

si insistir en el uso del condón con una pareja que se rehúsa a usarlo;

si dar por terminada una relación;

si tener o no relaciones sexuales con el fin de obtener un regalo o dinero para pagar la colegiatura;

si revelar o no el resultado de una prueba de VIH;

si continuar o dar fin a un embarazo no planeado; y

si decirle a los padres de uno sobre el hecho de tener sentimientos románticos o sexuales hacia alguien del mismo sexo.

Paso 5: Reconsiderar la decisión si es necesario.

Trate de tomarse tanto tiempo como necesite para recorrer todos los pasos de la toma de decisiones. Con frecuencia, nos sentimos mejor con decisiones que hemos tomado a conciencia. 


\section{nuestras decisiones como base de acción}

Después de tomar una decisión, haga un plan para llevar a cabo esa decisión. Aclare todos los pasos necesarios para actuar conforme a la decisión. Estos pasos incluyen:

Paso 1: Considerar lo que facilitará al máximo que la decisión se lleve a cabo.

Por ejemplo:

- hablar con sus padres cuando ellos no estén bajo presión;

- averiguar acerca de otros pares que hayan tomado y llevado a cabo decisiones similares (por ejemplo, niñas que adoptaron una posición para continuar con sus estudios, una amiga que invitó a alguien a salir, o personas que decidieron someterse a pruebas de VIH); y

- encontrar formas de obtener el dinero u otros recursos necesarios para llevar a cabo la decisión.

Paso 2: Pensar sobre barreras probables para llevar a cabo una decisión. Este paso es importante, porque algunas decisiones presentan una gran dificultad para ser llevadas a la práctica. Ejemplos de barreras potenciales incluyen:

- carecer de suficiente dinero (por ejemplo, para pagar el transporte en autobús a la clínica o para comprar textos escolares);

- carecer de acceso a los servicios (por ejemplo, escuelas y clínicas de difícil acceso);

- límites legales (como leyes que restringen el aborto o productos y servicios anticonceptivos para adolescentes no casados);

- temores a las consecuencias sociales (por ejemplo, declararse como homosexual, oponerse a la mutilación genital, resistirse al matrimonio temprano, ser vista en una clínica de planificación familiar, o trabajar en un empleo que usualmente es desempeñado por personas del otro sexo); y

- preocupaciones sobre los costos personales (por ejemplo, ser rechazada por una pareja por rehusarse a tener relaciones sexuales o por insistir en el uso del condón; o enfrentar un posible diagnóstico que le cambiaría la vida).

\section{Paso 3: Ensayar su decisión de forma segura o en privado.}

Por ejemplo:

- poner por escrito o practicar decirle a un adulto confiable acerca de un abuso sexual;

- practicar el uso de un condón (masculino o femenino);

- practicar con un amigo (si usted tiene una amigo en cuyo juicio confía y quien usted sabe que respetará su privacidad); y

- considerar si comunicar su decisión respetuosamente a alguien más que se verá afectado y cómo hacerlo. 
Paso 4: Analizar la decisión y el plan con una persona que se muestre solidaria.

Por ejemplo, usted podría:

- hablar con una consejera acerca de dar término a un embarazo;

- hablar con una persona que ya se haya hecho una prueba de VIH;

- encontrar una línea telefónica de emergencia, un centro de atención o una comunidad en línea en donde haya personas que puedan hablar con alguien que está pensando en cambiar de género.

Paso 5: Determinar la forma de llevar a cabo su decisión de la manera más segura.

Por ejemplo, usted podría:

- acompañarse de alguien para enfrentar a una pareja violenta; o

- encontrar una persona aliada entre los líderes de la comunidad, antes de comenzar una campaña a favor de la educación sexual.

Paso 6: Cuando sea apropiado, buscar información o asesoría de personas en las que usted confía.

Paso 7: Si surgen barreras al llevar a cabo una decisión, desarrolle un plan de acción diferente o reconsidere la decisión.

Paso 8: Esté consciente de que aún cuando las personas no encuentren una barrera, tienen el derecho de reevaluar las decisiones y cambiar de parecer.

VER EL LIBRO DE ACTIVIDADES Actividad 39

Ilevar a cabo decisiones difíciles

Las y los estudiantes aprenden los pasos básicos para implementar una decisión y crear una tira cómica que represente a una persona que implementa una decisión difícil. 


\section{EL CUERPO,}

PUBERTAD Y

REPRODUCCIÓN 


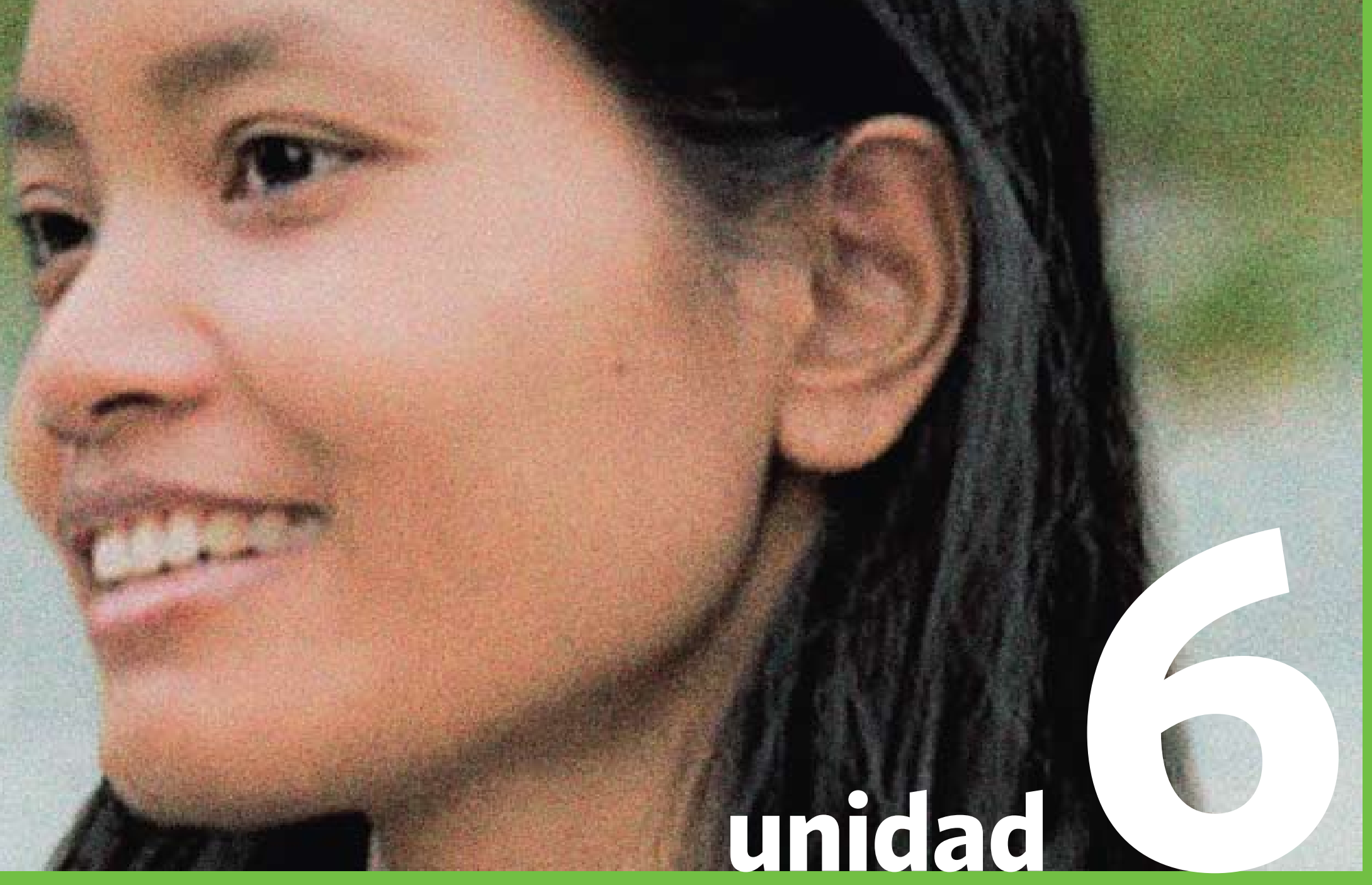




\section{visión general}

El cuerpo humano es bello en todas sus formas. La gente joven merece crecer con una sensación de familiaridad y confianza acerca de sus propios cuerpos. Tal familiaridad y confianza también les permiten tener un mejor cuidado de su propia salud sexual. Además, la gente joven necesita una buena nutrición, ejercicio, información y servicios de salud para mantener sus cuerpos en condiciones óptimas.

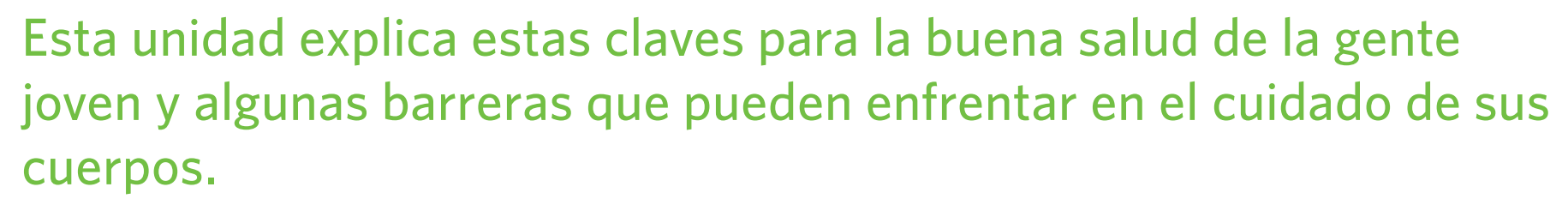




\section{EL CUERPO, PUBERTAD Y REPRODUCCIÓN}

Al abordar temas como la pubertad, los tipos corporales y el sistema reproductivo, tenga en cuenta que muchas veces las personas jóvenes son susceptibles respecto al hecho de si son o no son "normales". Enfóquese en la amplia gama de lo que es natural y evite términos como "anormal" y "antinatural".

El uso de los términos técnicos para las partes del cuerpo ayudará a sus estudiantes a sentirse más cómodos.

Tenga en cuenta que el comportamiento sexual de sus estudiantes se ve influenciado enormemente por factores sociales como las actitudes que ellas y ellos tienen respecto a los temas de género. Por su parte, muchos maestros acostumbren presentar información técnica sobre estos temas. Sin embargo, algunos recursos como las hojas informativas pueden transmitir esa información de manera eficiente, permitiendo a las y los maestros usar el tiempo limitado que tienen para enfocarse en los aspectos que requieren reflexión y diálogo.

Varias hojas informativas ubicadas al final de este volumen proporcionan detalles adicionales sobre los temas cubiertos en esta unidad. 


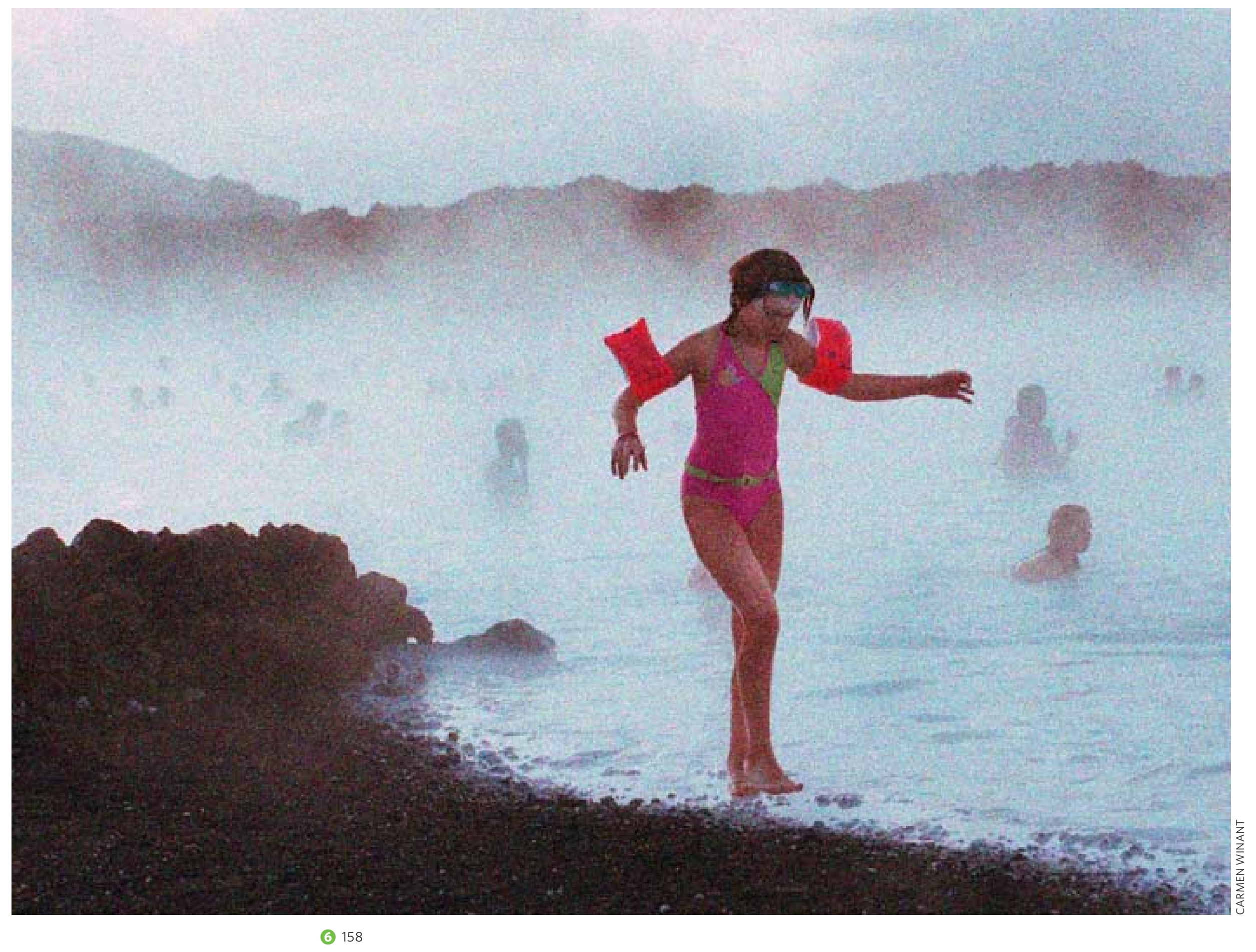




\section{EL CUERPO, PUBERTAD Y REPRODUCCIÓN}

El material en esta unidad prepara a las y los estudiantes para:

\section{Objetivos cognoscitivos}

Analizar en grupo al menos dos cambios físicos y dos cambios culturales o sociales que la gente joven experimenta en la pubertad, así como la forma en que esto varía para las niñas y los niños.

Hacer una lista de al menos dos formas en las que conocer nuestros cuerpos puede promover la salud sexual y el bienestar.

Describir los sistemas sexuales y reproductivos masculinos y femeninos, así como la forma en que ocurre la fecundación y la reproducción.

Explicar los roles de hombres y mujeres en la infecundidad.

\section{Objetivos afectivos}

Analizar en grupo (o escribir sobre) la forma en que las normas de género afectan la imagen corporal. Identificar algo sobre sus propios cuerpos de lo que tengan sentimientos positivos.

Identificar y analizar en grupo (o escribir) al menos una preocupación o temor acerca de si tienen la capacidad de proteger su salud sexual. 


\section{imagen corporal}

1 Los cuerpos de las personas difieren en apariencia. No hay un tipo de cuerpo o apariencia que sea "perfecto" o "normal", a pesar de los mensajes culturales y mediáticos que dicen lo contrario.

\section{Aprender a sentirse cómodo con el propio cuerpo - tener una imagen corporal positiva} - es un elemento importante de la autoestima.

- Experimentar con la propia apariencia puede ser divertido y creativo; puede ser una forma de explorar la propia identidad.

- La imagen corporal de las personas afecta el grado en que se sienten cómodas con la vida social, con la actividad física y con la sexualidad.

- Desarrollar este grado de comodidad puede ser un reto especialmente para quienes viven en comunidades que estigmatizan las discapacidades físicas.

\section{PUNTOS PARA REFLEXIÓN}

Varios factores pueden minar nuestra confianza sobre nuestros cuerpos o apariencia. Por ejemplo, considere las siguientes preguntas:

¿Qué tan realistas y flexibles son los mensajes e imágenes que recibimos de los medios de comunicación sobre cuáles tipos de cuerpos son atractivos, deseables y aceptables? ¿Qué hay de los mensajes que recibimos a través de la publicidad? ¿De nuestra comunidad? ¿De nuestra familia y amistades?

¿Cómo se siente hacer frente a la presión para satisfacer los ideales culturales sobre el cuerpo o sobre nuestra apariencia? ¿Enfrentar esa presión es más fácil o difícil durante la adolescencia?

¿Cómo se siente ser objeto de burlas sobre nuestros cuerpos o ser ridiculizados con base en nuestra apariencia?
(- 3 Los factores sociales e individuales afectan la confianza de las personas sobre sus

\section{propios cuerpos.}

Esos factores incluyen:

- el conocimiento sobre el propio cuerpo;

- la comprensión de que el cuerpo de una persona es su "propio" cuerpo;

- la internalización de las normas sociales que celebran o estigmatizan las diferentes apariencias y capacidades corporales;

- la comprensión de que las apariencias "ideales" varían a través de las culturas y del tiempo;

- la recepción de retroalimentación positiva o negativa sobre el propio cuerpo, independientemente de qué tan correctamente se parece o difiere del ideal cultural;

- la actividad física y el mantenimiento de una buena salud;

- la comprensión de los propios deseos físicos, incluido el evitar las relaciones sexuales indeseables, incómodas, irrespetuosas, coercitivas o violentas; $y$

- el contar con leyes y sistemas de apoyo que permitan que las personas con discapacidades tengan vidas plenas, ya sea de forma independiente, $\mathrm{o}$ ayudadas con asistencia respetuosa. 
4 Con frecuencia, las niñas y mujeres sienten presiones sociales intensas relacionadas con su apariencia física.

- La condición social de niñas y mujeres con frecuencia depende, de manera significativa, de su apariencia.

- Las prácticas culturales (desde los concursos de belleza hasta la mutilación genital) refuerzan la presión sobre las mujeres jóvenes para alcanzar ideales culturales de belleza.

- Las niñas y mujeres están muchas veces sujetas a comentarios y actos de acoso sexual que pueden ser molestos, incómodos y amenazantes.

- Las mujeres y, especialmente, las niñas son más vulnerables que los niños a tener sentimientos negativos sobre sus cuerpos; tales sentimientos pueden conducir a trastornos alimentarios.

- Algunas niñas que tienen una imagen corporal disminuida (o una baja autoestima en general) sienten que deben estar de acuerdo en tener relaciones sexuales con el fin de ganar amor y aprobación.

\section{Los hombres y niños pueden también sentir ansiedad acerca de su apariencia.}

- Pueden sentir presión para ser fuertes físicamente o atléticos con el fin de ser vistos como masculinos.

- Los niños y hombres están también sujetos a comentarios y acoso de tipo sexual.

- Algunos niños desarrollan trastornos alimentarios.

- Con frecuencia, los niños encuentran que reconocer o buscar apoyo para enfrentar estas preocupaciones es menos aceptable socialmente para ellos que para las niñas. 
6 Casi todas las personas que viven con una discapacidad física o enfermedad crónica pueden aún así experimentar todos los aspectos de su vida, incluida su sexualidad. Muchas veces, sin embargo, estas personas sufren discriminación y aislamiento físico y social debido a su condición física o de salud.

- Este estigma mina la confianza de la gente en sus cuerpos y en su capacidad de tener vidas sociales (y sexuales) a plenitud.

- Tal discriminación o estigma también afecta la capacidad de las personas para obtener vivienda, trabajo y acceso a espacios públicos.

- En todo el mundo, las personas que viven con discapacidades (así como las personas que viven con el VIH y SIDA) se han organizado para eliminar ese estigma y discriminación, así como para expandir su capacidad de tener vidas sexuales satisfactorias y participar plenamente en la sociedad.

7 Con el debido estímulo, todas las personas jóvenes pueden sentirse cómodas con su apariencia física. Pueden también desarrollar otras fuentes de autoestima y autovaloración. Por ejemplo, pueden enfocarse en el logro académico, talentos creativos y otras características.

\section{VER EL LIBRO DE ACTIVIDADES}

\section{Actividad 40}

\section{lo que tú ves en mí}

Las y los estudiantes dialogan sobre las presiones relacionadas con la apariencia. Escriben sobre las características físicas que les gustan de sí mismos y escuchan sobre las características no físicas que otras personas admiran en ellos. 


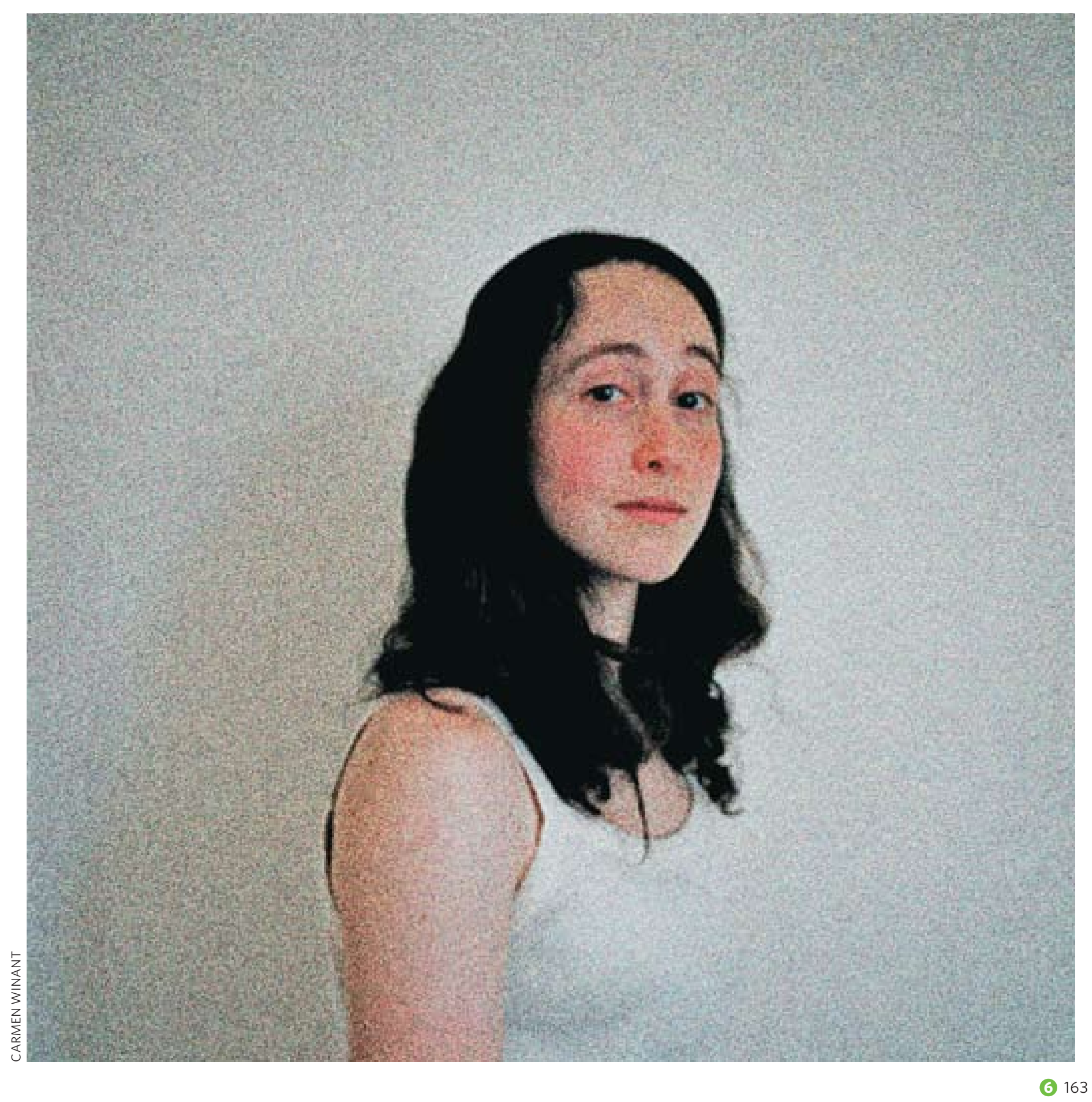




\section{pubertad}

Ver las hojas informativas sobre

Pubertad y niños; y sobre Pubertad y Niñas.
1 Conforme las y los niños se acercan a la adolescencia, sus cuerpos comienzan a producir sustancias químicas - llamadas hormonas - que provocan cambios en sus cuerpos y emociones. Este período de cambio se llama pubertad.

2 La pubertad ocurre más temprano para algunas personas y más tarde para otras.

- La edad en que ocurre la pubertad se ve influida por los genes, la nutrición, la actividad física y las enfermedades.

- Típicamente, las niñas llegan a la pubertad a una edad más temprana que los niños.

3 En la pubertad, los órganos sexuales y reproductivos comienzan a madurar.

- Para las niñas, los cambios físicos asociados con la pubertad incluyen el comienzo de la menstruación, el desarrollo de las mamas, el crecimiento de vello axilar y púbico, así como otros cambios físicos.

- Para los niños, la pubertad incluye el inicio de orgasmos involuntarios durante el sueño (llamados emisiones nocturnas o sueños húmedos); la producción de esperma; el crecimiento de vello facial, púbico y corporal; la gravedad de la voz; y otros cambios físicos. 
4 La pubertad puede producir al mismo tiempo confusión y expectación.

- Los aspectos tanto físicos como sociales de la pubertad conllevan cambios en la forma en que la gente joven siente respecto a sí misma y respecto a otras personas.

- Muchas personas adolescentes sienten curiosidad sobre el sexo y pueden explorar su sexualidad por sí solas, con un amigo o con una pareja sexual o romántica.

\section{Conforme las personas jóvenes llegan a la pubertad y comienzan a desarrollarse} sexualmente, encuentran que las personas que conocen - y la sociedad en general - se relacionan con ellas de manera diferente.

- Para quienes llegan a la pubertad, algunas culturas practican rituales de llegada a la madurez. La mayoría de esos rituales son celebraciones del crecimiento. Algunos de ellos, sin embargo, pueden ser dañinos. [Ver hoja informativa sobre Mutilación Genital Femenina.]

- Frecuentemente, las familias y comunidades esperan que las y los adolescentes asuman mayores responsabilidades y, algunas veces, les permiten tener mayor libertad.

- Muchas veces, las familias y comunidades ejercen una gran presión en las y los adolescentes para que se ajusten a los roles de género esperados.

\section{PUNTOS PARA REFLEXIÓN}

¿Cuáles son algunos sentimientos que la gente joven experimenta durante la pubertad?

¿Qué les provoca entusiasmo y curiosidad?

¿Qué preocupaciones pueden tener? 
6 Con frecuencia, los roles de género se agudizan dramáticamente en torno a la pubertad. Este cambio muchas veces se ve marcado por una creciente brecha en la igualdad y oportunidades entre niños y niñas.

\section{[Ver la Unidad 2.]}

Por ejemplo:

- Los niños son presionados para ser valientes y fuertes.

- Los niños pueden experimentar desaprobación si expresan ciertas emociones como la vulnerabilidad o la ternura.

- Muchas veces los niños se ven presionados a volverse sexualmente activos para probar su heterosexualidad. En contraste, en muchos entornos las niñas que son sexualmente activas se enfrentan a la desaprobación social. [Ver Unidad 3, páginas 90-91.]

\section{Actividad 41}

\section{cambios corporales}

Las y los estudiantes crean libros y canciones que explican los cambios físicos de la pubertad.

- En algunos entornos, las niñas encuentran que su libertad está seriamente coartada en la pubertad. Su asistencia a la escuela puede terminar, su estilo para vestir puede ser limitado, su comportamiento puede ser restringido y se le puede asignar deberes adicionales en el hogar.

- En particular, las niñas están sujetas a insinuaciones sexuales, tanto bien intencionadas como en forma de acoso.

- En algunos lugares, para las niñas llegar a la pubertad es señal de que están en edad de casarse.

- Tanto los niños como las niñas pueden experimentar presión o estigma relacionado con su identidad sexual o de género.

7 La pubertad es un período de rápido crecimiento físico, por lo que es especialmente importante cuidar el propio cuerpo. La gente joven frecuentemente enfrenta problemas especiales de salud en la adolescencia, incluida la necesidad de ejercicio físico seguro y nutrición apropiada. También, pueden enfrentar riesgos relacionados con el uso de drogas o alcohol.

[Ver hoja informativa sobre Nutrición, Actividad Física Saludable y Abuso de Substancias.]

\section{VER EL LIBRO DE ACTIVIDADES} Actividad 42

\section{pubertad: qué se puede} esperar

Las y los estudiantes analizan los cambios sociales que tanto niños como niñas experimentan durante la adolescencia. 


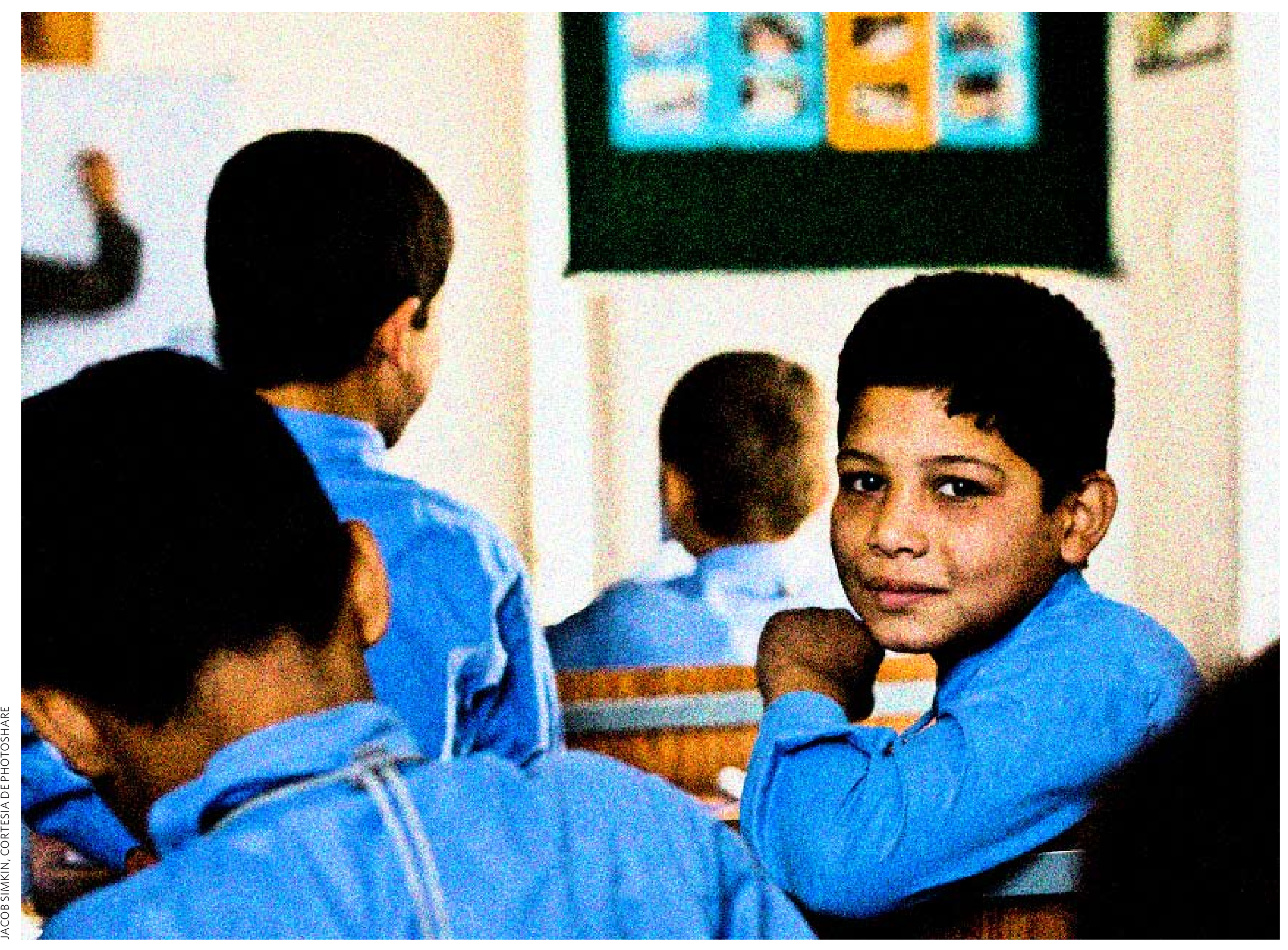




\section{conocimiento de nuestro cuerpo}

En particular, deberían facilitarse a los adolescentes información y servicios que les ayudaran a comprender su sexualidad y a protegerse contra los embarazos no deseados, las enfermedades de transmisión sexual y el riesgo subsiguiente de infecundidad. Ello debería combinarse con la educación de los hombres jóvenes para que respeten la libre determinación de las mujeres y compartan con ellas la responsabilidad en lo tocante a la sexualidad y la procreación. (Párrafo 7.41, Programa de Acción de la CIPD, 1994).

1 Aprender acerca del propio cuerpo puede ser una experiencia emocionante y empoderadora.

2 Adquirir conocimientos sobre nuestro cuerpo tiene muchos beneficios para la propia salud sexual y bienestar.

Por ejemplo:

- sentir que el cuerpo es propio, sentirse cómodo con el cuerpo que uno tiene;

- para las niñas, poder anticipar y manejar la menstruación;

- poder entender lo que se siente bien desde el punto de vista sexual;

- poder comunicar sentimientos y pensamientos relativos al sexo y la reproducción

- poder prevenir un embarazo no deseado;

- poder reconocer los síntomas de ciertas infecciones; y

- poder proteger su derecho a la dignidad y respeto.

VER EL LIBRO DE ACTIVIDADES

\section{Actividad 43}

hechos graciosos acerca del cuerpo

Mediante un crucigrama y un ejercicio, las y los estudiantes revisan y aprenden "hechos fascinantes" sobre el cuerpo y la reproducción. 
3 Con frecuencia, la sociedad envía mensajes imprecisos y dañinos a la gente joven sobre el cuerpo desde el punto de vista sexual; estas actitudes pueden retener la capacidad de hacer daño en la vida adulta.

4 Muchas personas jóvenes deciden por sí mismas aprender sobre el cuerpo y compartir con sus pares lo que aprenden.

5 En todo el mundo, hay gente joven y adulta que está trabajando para promover mensajes más precisos y más positivos acerca de la sexualidad y el cuerpo.
PUNTOS PARA REFLEXIÓN

¿Piensa usted que aprender sobre el cuerpo hace que las personas se sientan cómodas o avergonzadas de sus propios cuerpo o de sus órganos sexuales? ¿Por qué?

¿Por qué las niñas necesitan aprende acerca de la menstruación antes de llegar a la pubertad?

¿Qué sabe y siente usted acerca de la mutilación genital femenina? [Ver hoja informativa sobre Mutilación Genital Femenina.]

¿Cuáles son algunas razones por las que la gente usa términos groseros e irrespetuosos para referirse a los genitales; $y$, especialmente, para los órganos genitales femeninos, como la vagina?

¿Mantiene la gente algunas veces actitudes estereotipadas sobre la sexualidad o los cuerpos de personas de otros grupos raciales o étnicos? ¿Es esto un ejemplo de la forma en que los prejuicios sobre la raza y el género a veces se mezclan?

¿Qué actitudes tienen la gente sobre la sexualidad de las personas que viven con discapacidades?

¿Qué tipo de imágenes del cuerpo son promovidas en la publicidad y los medios de comunicación? 


\section{órganos sexuales y reproductivos}

Ver las hojas informativas sobre el sistema sexual y reproductivo femenino y masculino y la unidad 3, página 98.
1 Algunos órganos están involucrados primordialmente en la reproducción, en el placer sexual o en ambos.

Por ejemplo, en los hombres:

- El pene está involucrado tanto en el placer sexual como en la reproducción.

- Los testículos son órganos esenciales en la reproducción y están también involucrados en el placer sexual.

En las mujeres:

- El útero está involucrado solamente en la reproducción.

- El clítoris es el único órgano cuyo único propósito es el placer sexual.

\section{Algunos otros órganos también desempeñan roles en el sexo y la reproducción.}

Por ejemplo:

- La piel puede responder sexualmente a las caricias.

- El cerebro procesa emociones y secreta hormonas que afectan los sentimientos y la función sexual y reproductiva.

3 Los estándares de la comunidad acerca de la sexualidad y el género frecuentemente dan forma a las actitudes acerca de las partes del cuerpo y pueden conducir a mitos.

En algunos entornos, por ejemplo, las personas pueden no saber que:

- el sexo implica más que solamente los órganos sexuales y que se refiere a mucho más que el orgasmo.

- un himen (la delgada membrana de piel ubicada dentro de la abertura vaginal) roto no es una indicación de que la niña ha dejado de ser virgen. El himen puede romperse como resultado de la actividad física durante la niñez.

- la vagina se auto limpia en forma natural; el "duchado vaginal" o lavarse dentro de la vagina es innecesario y a veces dañino.

- en muchos entornos el tamaño del pene parece ser una mayor preocupación entre los hombres que entre sus parejas femeninas.

\section{Algunas personas que desean cambiar su género y sexo pueden usar hormonas y/o} someterse a cirugía para alterar sus órganos sexuales de manera permanente.

- Tales procedimientos son complicados y costosos, pero son de vital importancia para quienes buscan el cambio.

- Las personas adultas que desean cambiar de sexo deben tener acceso a consejería para ayudarles a tomar esta decisión, y deben sentirse libres de decidir si hacerlo o no. 


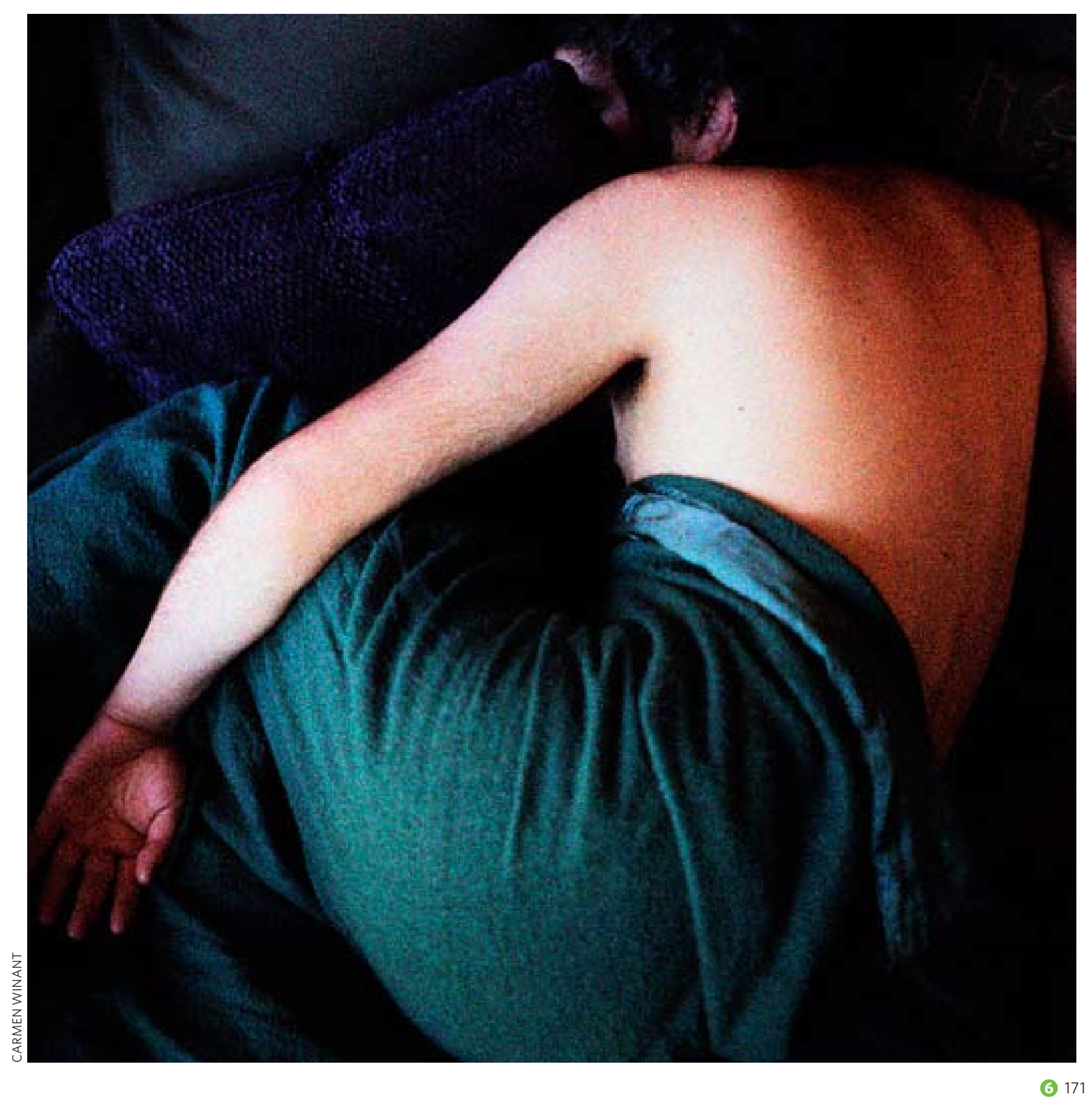




\section{fecundidad y reproducción (¿de dónde vienen los bebés?)}

1 Una mujer o pareja puede elegir tener hijos o no tenerlos. Esta es una decisión que es un derecho básico.

[Para mayor información sobre la prevención o terminación de un embarazo no deseado, ver la Unidad 7, Parte 2.]

2 Biológicamente, la fecundidad femenina es la capacidad de embarazarse y llevar un embarazo hasta el nacimiento. La fecundidad masculina es la capacidad de proporcionar esperma saludable capaz de iniciar un embarazo saludable.

- La fecundidad de una mujer varía a lo largo del curso de su ciclo ovulatorio-menstrual [ver hoja informativa sobre el Ciclo Menstrual.] La fertilidad de un hombre no varía de forma cíclica.

- Tanto los hombres como las mujeres pueden ser infecundos o tener una baja fecundidad. La infecundidad tiene muchas causas, incluidas las infecciones de transmisión sexual, las enfermedades, las toxinas ambientales y factores genéticos o físicos. Algunas de estas causas pueden prevenirse.

- La fecundidad declina en forma natural con la edad tanto en las mujeres como en los hombres, aunque este declive tiene lugar en las mujeres a edad más temprana. [Ver hojas informativas sobre Infecundidad y sobre el Ciclo Menstrual.]

\section{Muchos pasos conducen al embarazo.}

[Ver hoja informativa sobre Reproducción y Embarazo.]

- Iniciando en la pubertad, las niñas comienzan a ovular; esto es, generalmente liberan un óvulo maduro con cada ciclo ovulatorio-menstrual.

- Iniciando en la pubertad, los niños producen continuamente millones de pequeñas células llamadas espermatozoides.

- Cuando un espermatozoide se une a un óvulo (fecundación) se puede formar un embrión. El sexo del embrión es determinado por el espermatozoide, no por el óvulo de la mujer.

- Un embarazo resulta si el embrión se adhiere (se implanta) al recubrimiento del útero. Si continúa el embarazo este embrión se desarrollará en feto. 
4 Más comúnmente, un embarazo ocurre a través del coito heterosexual, durante el cual el pene entra en la vagina y el hombre eyacula, liberando esperma.

- Las personas usan varios nombres para referirse al coito sexual que incluyen, por ejemplo, "hacer el amor" o "tener relaciones sexuales". (Estos términos también son usados para otros comportamientos sexuales.)

- Para que ocurra un embarazo viable, son necesarias las siguientes condiciones:

- La mujer tiene que estar próxima al momento de su ciclo menstrual en el que ella libera un óvulo maduro de su ovario en la trompa de Falopio (el proceso se llama ovulación). [Ver también la Unidad 7, página 212.]

- El hombre tiene que tener una erección y eyacular dentro o en la abertura de la vagina de la mujer.

- Muchos espermatozoides deben viajar por la trompa de Falopio, en donde un sólo espermatozoide debe unirse con el óvulo (fecundación); y el óvulo fecundado debe entonces viajar hacia el útero de la mujer y quedar adherido (o implantado) en la pared uterina.

- El embarazo puede ocurrir independientemente de que la mujer tenga o no un orgasmo.

5 El embarazo puede ocurrir por medios diferentes al coito vaginal.

- Las personas que tienen dificultad para concebir, quienes carecen de una pareja sexual o que tienen una pareja del mismo sexo, pueden buscar otros medios de lograr el embarazo.

- Existen varios medios médicos para unir un óvulo y un espermatozoide [ver hoja informativa sobre Infecundidad y Reproducción Asistida.]

6 Dependiendo de la región o país, solamente de un 40 a un 70 por ciento de los embarazos resultan en un nacimiento vivo. El 30 a 60 por ciento de los embarazos restantes terminan en un aborto inducido o espontáneo, o muerte fetal. 


\section{cuando el embarazo continúa}

1 Todos los días, muchos miles de mujeres y niñas toman la decisión de continuar o terminar con sus embarazos.

[Ver la Unidad 7, páginas 214-217.]

2 Para quienes continúan con sus embarazos, usualmente el embarazo y el parto tienen lugar sin mayores problemas. En algunos casos, sin embargo, el embarazo y parto pueden presentar graves complicaciones, incluida la muerte de la madre o del infante. [Ver las hojas informativas sobre Reproducción y Embarazo y sobre Parto y Amamantamiento, que contienen mayor información sobre la forma de promover resultados saludables para las madres, así como para reducir el riesgo de los bebés de contraer el VIH y tener otros problemas graves.]

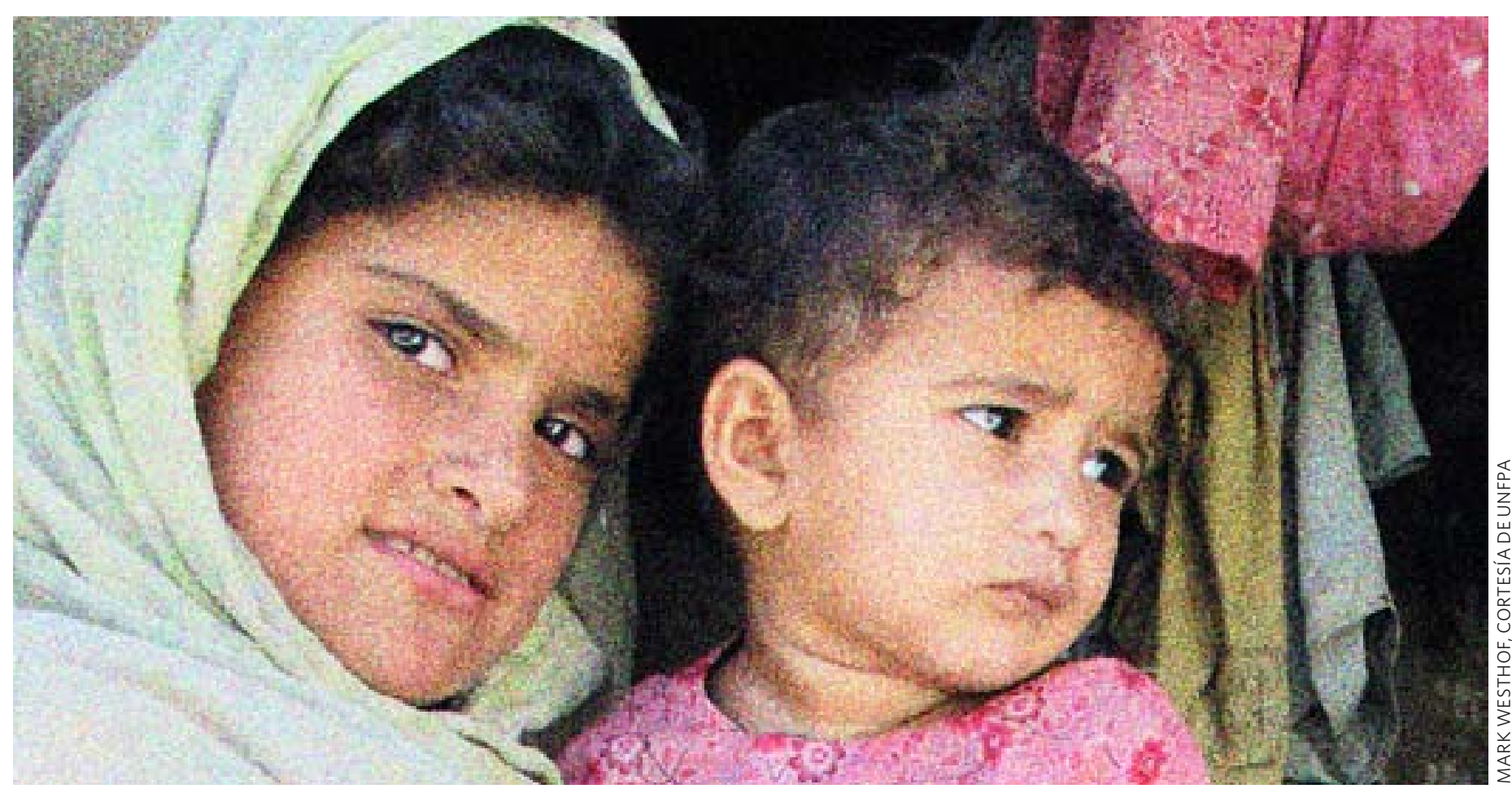


3 La pobreza y el acceso inadecuado a la atención a la salud son las principales causas de problemas relacionados con el embarazo y el parto.

- El acceso adecuado a la atención a la salud durante el embarazo y el parto es un derecho básico, pero no siempre está disponible.

- Muchas niñas y mujeres sufren daños agudos o duraderos, o discapacidad durante el embarazo y el parto. Esta situación es particularmente probable si están desnutridas, si dan a luz en la adolescencia temprana, o si carecen de acceso a la atención obstétrica de emergencia. Un problema serio es que la pelvis de la madre puede no ser lo suficientemente grande para permitir el paso del bebé. Sin un acceso inmediato a la cirugía, su tejido vaginal puede romperse en otras partes de su cuerpo y causar un escape continuo de orina o heces. Esta rotura se llama fístula obstétrica. La fístula puede ser reparada pero no siempre está disponible la cirugía para corregir esta condición. [Ver hoja informativa sobre Parto y Amamantamiento.]

- A nivel mundial, la falta de acceso a una atención médica adecuada contribuye cada año a más de medio millón de muertes relacionadas con el embarazo en mujeres y niñas - esto es, una muerte cada minuto.

\section{Aún en entornos con mayores recursos, algunas prácticas relacionadas con el embarazo}

y parto pueden causar daño innecesario a la madre y/o al recién nacido. Los activistas que trabajan a favor de la salud de las mujeres y muchos profesionales de la medicina han expresado su preocupación sobre varias de estas prácticas.

Algunas de las prácticas que han sido sujetas a un escrutinio especial incluyen:

- cirugías de sección cesárea innecesarias;

- uso excesivo de analgésicos u otros medicamentos durante el embarazo;

- preferencia por la fórmula infantil en lugar de la leche materna; y

- la separación rutinaria de los recién nacidos de sus madres.

\section{PUNTOS PARA REFLEXIÓN}

Más del 99 por ciento de las muertes relacionadas con el embarazo y parto tienen lugar en los países en desarrollo. Casi todas estas muertes pueden prevenirse.

¿Qué se necesitaría para convencer a los gobiernos de que financien y proporcionen servicios de ayuda para prevenir esas muertes?

¿Qué se necesitaría para convencer a los esposos y parientes políticos de que paguen por el transporte y la atención a la salud de una mujer embarazada?

¿Qué tan fácil es para toda mujer o niña ejercer su derecho a una atención adecuada durante el embarazo y parto? 


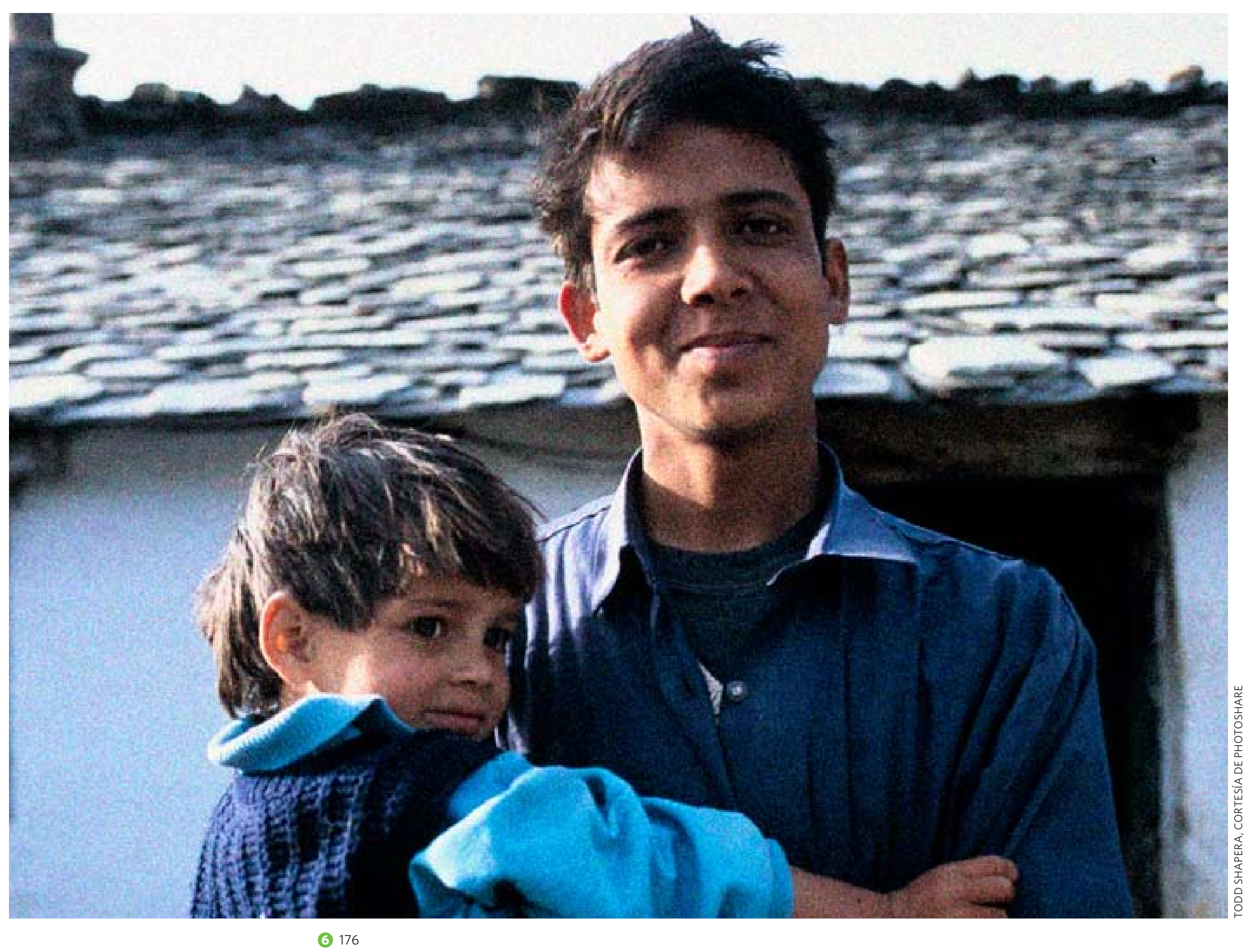


5 Las normas culturales relacionadas con el parto (incluido el rol de la pareja masculina) varían ampliamente y están cambiando.

- En muchos lugares, la condición de la mujer puede depender en parte del hecho de tener hijos. Sin embargo, especialmente en donde las mujeres están logrando oportunidades en otras áreas de la vida, ellas pueden sentir menor presión para tener hijos.

- Algunas personas creen que el embarazo y parto debe ocurrir solamente dentro de la relación aprobada socialmente del matrimonio. De manera creciente, en todo el mundo muchas otras personas creen que las y los niños pueden crecer felices y saludables, independientemente de la forma que tome su familia.

- En un cada vez mayor número de lugares, los hombres están tomando un rol más activo durante el embarazo y parto. Están alentando y asistiendo a las visitas prenatales, asistiendo a clases de parto, estando presentes en el parto y, lo que es muy importante, participando activamente en el cuidado de infantes, niñas y niños.

6 Aunque no todas las parejas eligen tener hijos, quienes sí los desean pero son infecundos (incapaces de tener hijos) pueden sufrir una gran decepción o estigma.

- En las parejas infecundas, con frecuencia la mujer es "culpada", aún cuando la fuente del problema tiene la misma probabilidad de radicar en el hombre.

- Si una pareja es incapaz de concebir, en algunos entornos los hombres tienen derecho a buscar otra esposa (o la familia del hombre puede buscar una esposa para él).

\section{Las personas que tienen dificultad para embarazarse pueden tomar diferentes medidas.}

Por ejemplo:

- Las mujeres pueden aprender a identificar si están ovulando y cuándo ocurre la ovulación (el período fecundo del ciclo menstrual). [Ver hoja informativa sobre el Ciclo Menstrual.]

- Hay técnicas disponibles para la reproducción asistida. Sin embargo, tales procedimientos pueden complicarse y son costosos y no siempre son efectivos. [Ver también la hoja informativa sobre Infecundidad y Reproducción Asistida.]

- Muchas parejas infecundas adoptan hijos, tal y como lo hacen algunas personas que son fecundas.

\section{VER EL LIBRO DE ACTIVIDADES} Actividad 44

reproducción: más que un asunto privado

Las y los estudiantes aprenden sobre 15 temas contemporáneos relacionados con la reproducción (desde la paternidad adolescente hasta la selección de sexo). Escriben resúmenes basados en hechos y sus reacciones personales.

VER EL LIBRO DE ACTIVIDADES Actividad 45

cada minuto de cada

hora: relatos de muertes relacionadas con el embarazo

Las y los estudiantes leen estudios de caso de muerte materna. A través de relatos cortos y análisis en conjunto, exploran cómo esas muertes pudieron haberse prevenido. 


\section{aprendizaje sobre el propio cuerpo: un movimiento global}

1 En todo el mundo, las personas, especialmente las mujeres y las niñas, están tomando medidas para enseñarse a sí mismas y unas a otras sobre sus cuerpos, incluidos sus sistemas y su salud sexual y reproductiva.

2 Virtualmente en cada país, se ha constituido grupos formales o informales que ofrecen talleres de auto ayuda, programas de teatro y radio, así como materiales informativos sobre el cuerpo.

3 Muchos grupos que inician con un enfoque de ayuda para que la gente aprenda sobre sus cuerpos, también realiza labor de advocacy a favor de cambios sociales más amplios.

Por ejemplo, trabajan para:

- una mejor educación sexual en escuelas y comunidades;

- poner fin a prácticas culturales que son dañinas;

- servicios de salud sexual y reproductiva más accesibles y más respetuosos;

- prevención y tratamiento más eficaz de cánceres del sistema reproductivo [ver la hoja informativa sobre Cánceres del Sistema Reproductivo];

- leyes que protejan los derechos sexuales y reproductivos; y

- nuevas normas en la comunidad que fomenten la responsabilidad conjunta de hombres y mujeres para la salud sexual y reproductiva. 


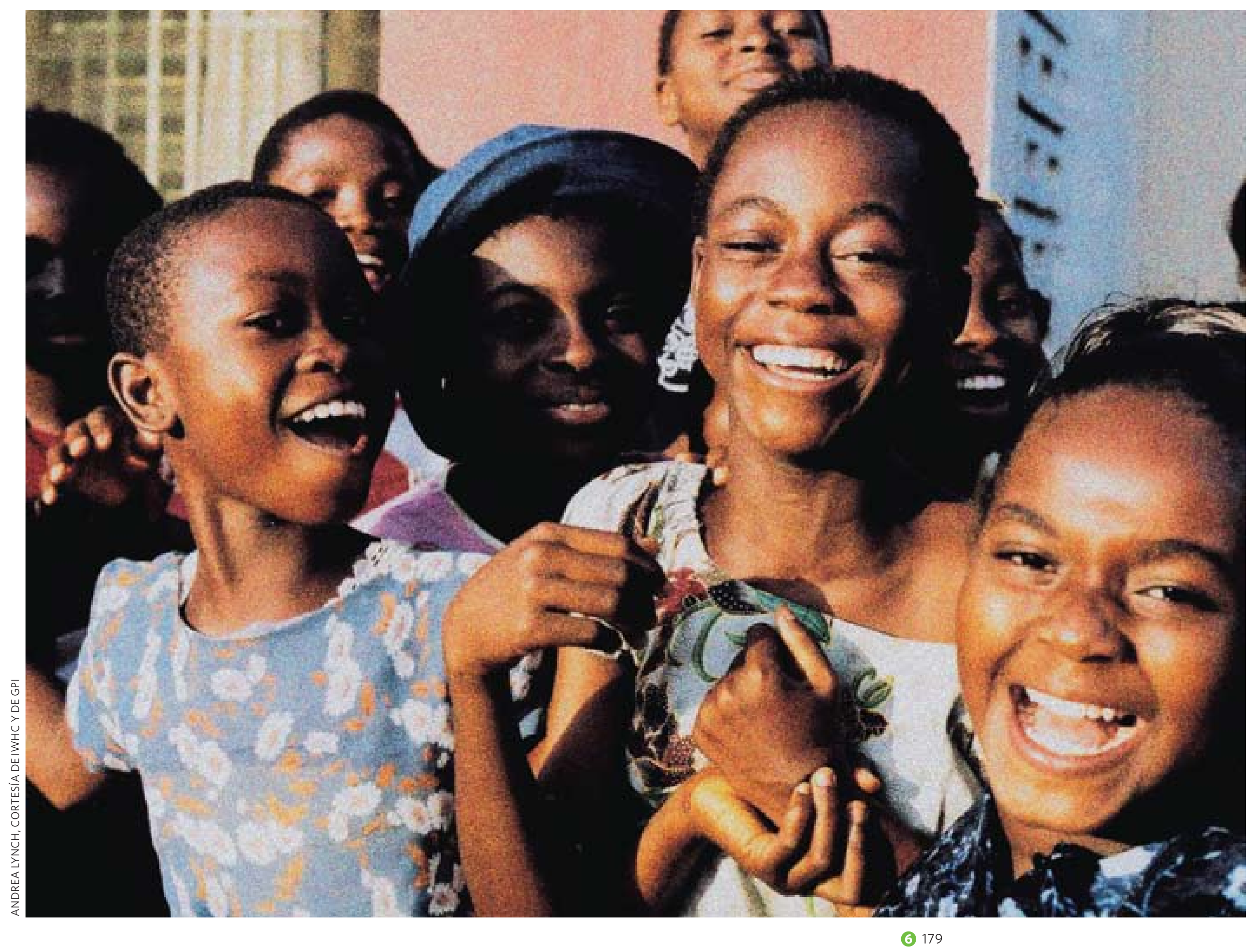




\section{SALUD SEXUAL Y REPRODUCTIVA}


( -2

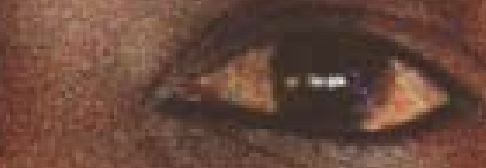

s.9.

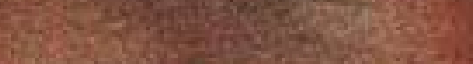

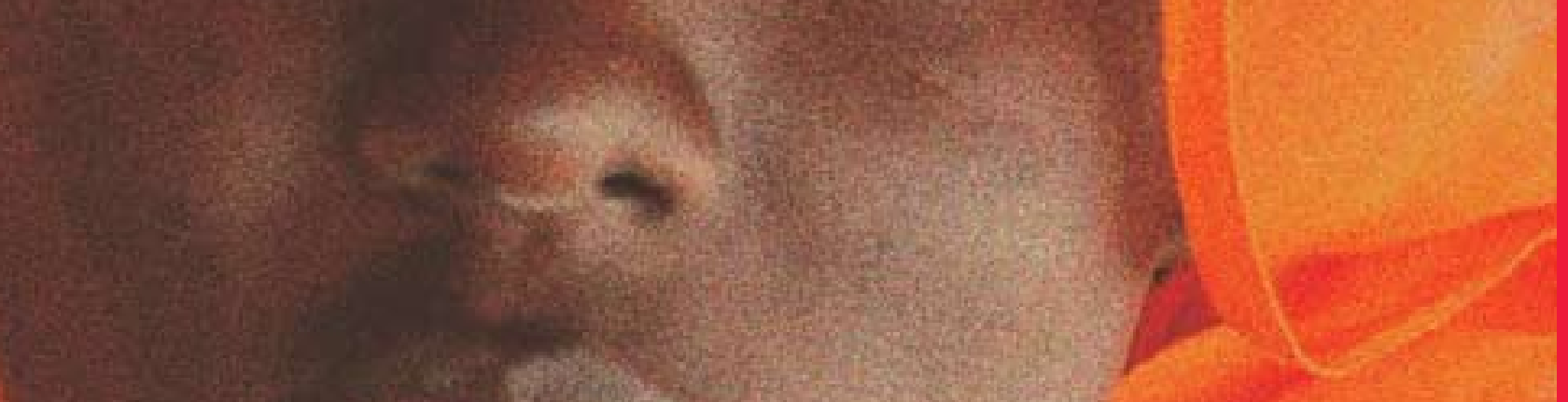

4.

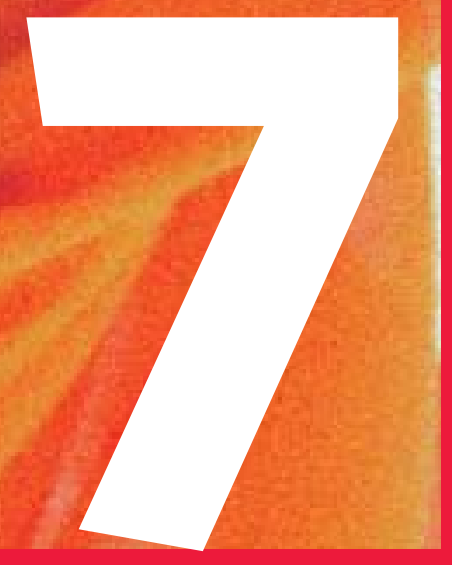




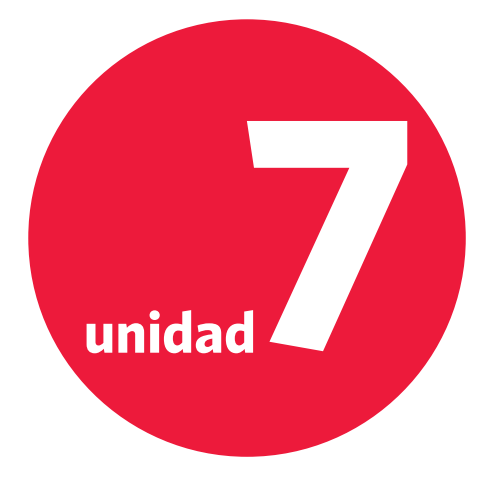

\section{visión general}

La sexualidad y la reproducción pueden ser fuentes de profunda satisfacción, placer y realización en la vida de las personas. Sin embargo, las relaciones sexuales puede también conducir a problemas de salud, si ambos miembros de la pareja no se aseguran de protegerse a sí mismos y mutuamente del embarazo no planeado y las infecciones, incluido el VIH. Un paso clave para mejorar el bienestar sexual y reproductivo de las personas es asegurar que tengan acceso a información y servicios. Otro paso es crear condiciones sociales más justas - lo que incluye la igualdad de género y el respeto por los derechos de las personas - que permitan que todas las personas controlen las circunstancias bajo las cuales tienen relaciones sexuales.

Esta unidad proporciona información vital para ayudar a la gente joven a mantener la seguridad y bienestar de sus cuerpos. 


\section{SALUD SEXUAL Y REPRODUCTIVA}

Esta unidad cubre el tema final "de contenido" de Un sólo currículo. (La Unidad 8 es un módulo basado en proyectos para el desarrollo y práctica de habilidades de ciudadanía.) La salud sexual y reproductiva aparece al último debido a que los resultados individuales en materia de salud sexual y reproductiva con frecuencia son resultado de los factores sociales y personales abordados en las unidades anteriores.

Al desarrollar un currículo o al enseñar con base en este material, las y los educadores pueden apoyarse en las hojas informativas que acompañan este kit de recursos. Sin embargo, el conocimiento científico y la información importante en el área de salud sexual cambian continuamente. Por lo tanto, es esencial buscar, a partir de fuentes confiables, información actualizada y que sea relevante a nivel local.

Enseñar sobre VIH y SIDA requiere de una gran sensibilidad, especialmente en entornos con una gran prevalencia de la infección.

Trate de evitar términos como "natural" o "normal" para describir aspectos de la sexualidad que son, en realidad, nada más que convenciones culturales o normas que hemos adoptado.

Varias hojas informativas al final de este volumen proporcionan detalles adicionales sobre los temas cubiertos en esta unidad. 


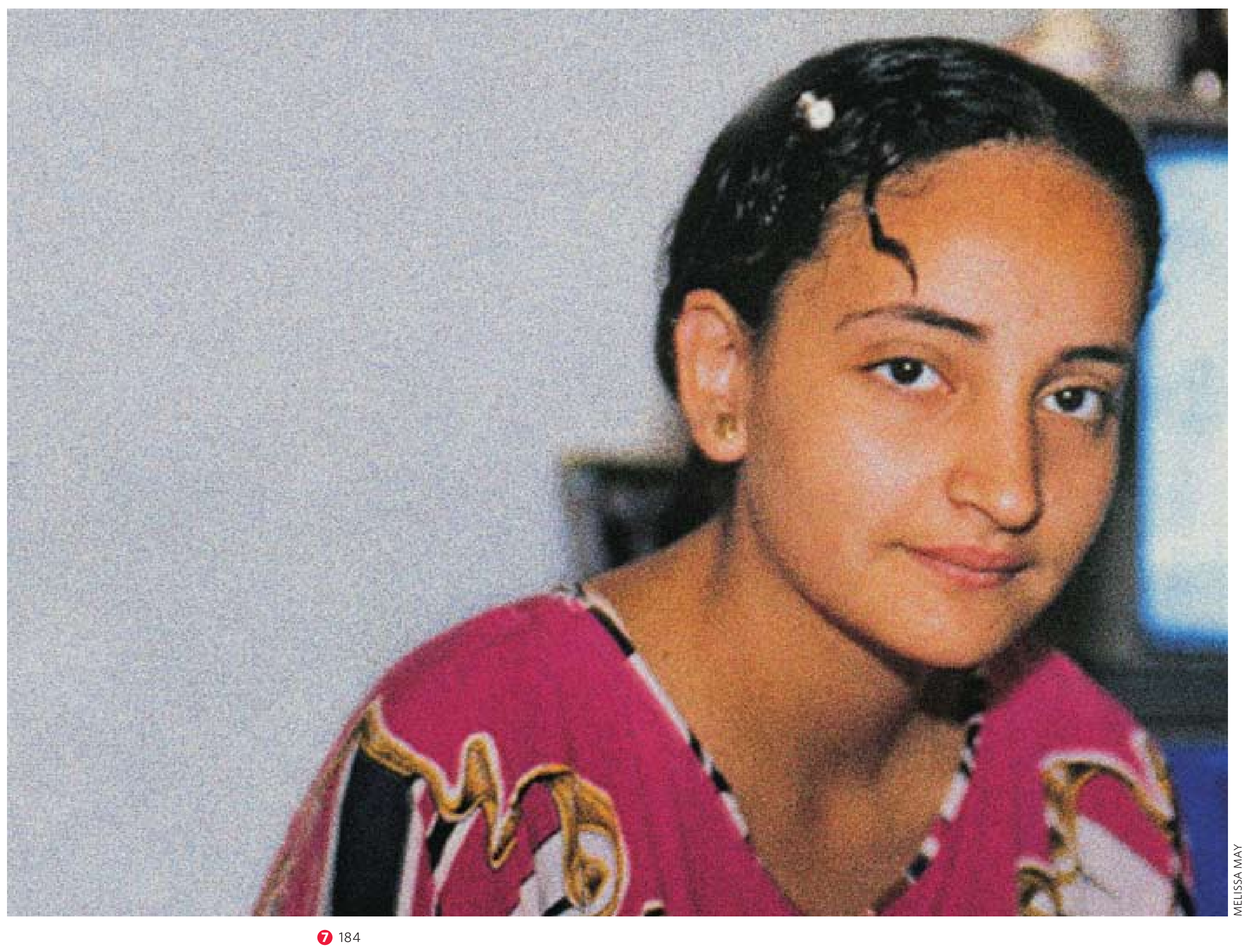




\section{SALUD SEXUAL Y REPRODUCTIVA}

El material en esta unidad prepara a las y los estudiantes para:

\section{Objetivos cognoscitivos}

Analizar en grupo los aspectos claves relacionados con el acceso a los servicios de salud sexual y reproductiva (incluida la atención al embarazo y parto) en su entorno.

Analizar en grupo los derechos de todas las personas para protegerse a sí mismas contra las ITS y el VIH.

Explicar la naturaleza asintomática y las consecuencias que tienen la clamidia y la gonorrea para la fecundidad en las mujeres.

Mencionar hechos claves sobre la transmisión, diagnóstico, consecuencias y tratamiento para el VIH y el SIDA.

Analizar en grupo las consecuencias del VIH y el SIDA para las familias, comunidades y países; y los derechos de las personas que viven con el VIH y el SIDA.

Mencionar las razones principales por las que las personas pueden no usar anticonceptivos, aún cuando no deseen un embarazo.

Analizar en grupo las características de al menos tres métodos anticonceptivos, incluido su efecto en las ITS.

Describir al menos seis situaciones personales en las que una mujer puede decidir terminar un embarazo.

Explicar por qué la mortalidad materna, incluida la que se deriva del aborto, puede prevenirse en gran parte.

\section{Objetivos afectivos}

Reconocer el rol de la desigualdad de género en la transmisión de ITS y VIH o en el embarazo no deseado.

Reflexionar sobre su opinión acerca de la indecisión y la responsabilidad de las personas de revelar su condición de ITS y VIH a sus parejas sexuales.

Reflexionar sobre su opinión acerca del uso de anticonceptivos y del condón, incluida la forma en que su uso puede afectar la relación sexual (positiva o negativamente) y sobre las barreras que pueden haber experimentado para su uso.

Explorar y analizar en grupo sus opiniones respecto al aborto legal y seguro.

\section{Objetivos basados en destrezas}

Demostrar sus conocimientos acerca del uso apropiado del condón. 


\section{el derecho a los servicios de salud}

Toda persona tiene derecho a ... la asistencia médica y los servicios sociales necesarios (Artículo 25, UDHR, 1948; Artículo 12, CEDAW, 1979; Artículo 12, ICESCR, 1966; Artículo 24, CRC, 1989).

En particular, deberían facilitarse a los adolescentes información y servicios que les ayudaran a comprender su sexualidad y a protegerse contra los embarazos no deseados, las enfermedades de transmisión sexual y el riesgo subsiguiente de infecundidad. Ello debería combinarse con la educación de los hombres jóvenes para que respeten la libre determinación de las mujeres y compartan con ellas la responsabilidad en lo tocante a la sexualidad y la procreación. (Párrafo 7.41, Programa de Acción de la CIPD, 1994).

1 Toda persona joven necesita acceso a los servicios de salud como parte de tener una vida sexual segura, responsable y saludable.

2 Todas las personas tienen el derecho a servicios de salud que sean accesibles, asequibles y de buena calidad. Las personas tienen derecho a ser tratadas con respeto y a mantener su privacidad.

3 Desafortunadamente, muchas barreras pueden impedir que las personas obtengan los servicios de salud que necesitan y merecen. Algunas de estas barreras reflejan discriminación y estigma informal. Algunas veces, estas barreras se convierten en políticas formales.

- Los gobiernos pueden no proporcionar servicios de salud gratuitos y asequibles en todas las áreas.

- Los gobiernos, prestadores de servicios o farmacias pueden impedir el acceso a ciertos servicios de salud y medicamentos. Sus acciones pueden verse influidas por convicciones políticas o creencias religiosas.

- Las compañías farmacéuticas pueden cobrar precios inaccesibles por medicamentos y suministros.

- Algunos programas de salud pueden requerir que la gente joven, especialmente las niñas, obtengan consentimiento paterno antes de recibir servicios anticonceptivos. 


\section{Una mala calidad de atención puede desmotivar a las personas a que acudan a los}

servicios de salud disponibles.

Por ejemplo:

- Las y los clientes pueden tener que soportar largas esperas por los servicios o pueden no recibir los suministros o servicios que necesitan.

- Algunas y algunos clientes (especialmente si son personas solteras, viven en condiciones de pobreza, se dedican al trabajo sexual, pertenecen a minorías raciales/étnicas, transgénero, viven en una relación del mismo sexo o si viven con el VIH o SIDA) experimentan trato prejuiciado por parte de prestadores de servicios de salud.

- Las y los adolescentes con frecuencia tienen temores reales o percibidos de que su familia o amistades descubrirán acerca de su visita a los servicios de salud.

\section{Las normas de género influyen en el uso de los servicios.}

- Muchos hombres jóvenes pueden sentirse incómodos al buscar servicios de salud sexual, especialmente cuando tales servicios están dirigidos principalmente a las mujeres.

- Muchas mujeres y gente joven carecen del poder de decisión o del dinero que necesitan para obtener los servicios.

- Algunas niñas y mujeres tienen prohibido salir de sus hogares o poblados sin compañía, aún si van a una clínica de servicios de salud.

6 A pesar de los obstáculos, millones de personas, incluida la gente joven, usan servicios de salud e interactúan bien con las personas que les prestan los servicios.

\section{Muchas personas en todo el mundo se están organizando con éxito para mejorar la salud} de sus comunidades.

Por ejemplo, ellas:

- establecen actividades de educación en salud comunitaria para enseñar a otras personas sobre temas de salud;

- establecen servicios de salud sexual y reproductiva que son especialmente acogedores para la gente joven, e incluyen consejería, consentimiento informado y respeto por la confidencialidad;

- educan a su comunidad sobre la fístula obstétrica y llevan a cabo labor de advocacy a favor de servicios que proporcionen la reparación quirúrgica para las mujeres que padecen esta debilitante condición (ver Unidad 6, página 175 y la hoja informativa sobre Parto y Amamantamiento);

- establecen proyectos comunitarios para mejorar la salud, como programas de jardinería, pozos de agua y ejercicio;

- realizan trabajo de advocacy a favor de mejores servicios de salud (incluida una creciente disponibilidad de medicamentos); y

- realizan trabajo de advocacy a favor de mejores políticas de salud y para lograr un mayor financiamiento para la atención a la salud. 


\section{PARTE 1: INFECCIONES DE TRANSMISIÓN SEXUAL, INCLUIDOS EL VIH Y EL SIDA}

Los gobiernos, las organizaciones internacionales, donantes y ONG.... deben tomar iniciativas en que se tenga en cuenta el género para hacer frente a las enfermedades de transmisión sexual, y el VIH/SIDA ... (Objetivo Estratégico C3, Plataforma de Acción de la CCMM, 1995). [Esto debe incluir ... estrategias para poner fin a la subordinación social de las mujeres y las niñas y ... para informar a los hombres y capacitarles para que asuman sus responsabilidades en la prevención del VIH/SIDA y otras enfermedades de transmisión sexual (Párrafo 108.e, Plataforma de Acción de la CCMM, 1995). 


\title{
acerca de las infecciones de transmisión sexual (ITS), VIH y SIDA
}

1 Las personas pueden experimentar consecuencias tanto positivas como negativas como resultado de su actividad sexual.

- Los resultados positivos incluyen el placer, la intimidad y (en las parejas heterosexuales) el embarazo deseado.

- Las consecuencias negativas pueden incluir daño emocional y físico; las infecciones de transmisión sexual, incluido el VIH; o, (en las parejas heterosexuales) el embarazo no planeado.

2 Las infecciones de transmisión sexual (también llamadas ITS) son infecciones que se propagan a través de la actividad sexual. Las ITS son prevenibles.

[Ver hoja informativa sobre Infecciones de Transmisión Sexual.]

- Algunas ITS causan síntomas o incomodidad. Otras no siempre tienen síntomas (especialmente en las mujeres).

- Aún cuando una infección no produzca síntomas, puede tener consecuencias de salud serias, incluido el poner en peligro la fecundidad o la propia vida.

- Entre las ITS que pueden tener serias consecuencias están: el VIH, el VPH (verrugas genitales), la sífilis, la gonorrea, la clamidia, las tricomonas y el herpes.

- Las relaciones sexuales orales conllevan algún riesgo de transmisión del VIH.

- Para algunas ITS, las niñas son fisiológicamente más vulnerables a la infección que los niños. El coito anal receptivo aumenta el riesgo de infección (para niños y para niñas). Algunos factores sociales afectan la probabilidad de transmisión. [Ver sección en esta unidad titulada Razones por las que la gente no usa protección.]

3 Las personas que son sexualmente activas pueden tomar medidas para reducir el riesgo de contraer una ITS.

[Ver la siguiente sección titulada Métodos de Protección Contra las ITS y el VIH.]

\author{
VER EL LIBRO DE ACTIVIDADES \\ Actividad 46 \\ hechos acerca de las \\ infecciones de transmisión \\ sexual (ITS) \\ Las y los estudiantes elaboran \\ carteles que muestren información \\ importante acerca de las ITS, \\ incluidos el VIH y el SIDA.
}


4 Una de las infecciones más graves que las personas pueden contraer a través de la relación sexual es el VIH, el virus que causa el SIDA. El SIDA es una de las principales causas de enfermedad y muerte en muchas partes del mundo.

[Ver hoja informativa sobre VIH y SIDA.]

- El VIH debilita el sistema inmune humano, permitiendo el desarrollo de infecciones y cánceres. Sin tratamiento, eventualmente conduce a la muerte.

- Las tasas de infección por VIH varían entre los países y dentro de los países.

- En muchos lugares, las tasas de VIH son mucho más altas en la gente joven, especialmente en las niñas. En muchos lugares, los hombres que visitan a trabajadoras sexuales y los hombres que tienen relaciones sexuales con hombres, pueden ser también especialmente vulnerables a la infección por VIH.

- El VIH puede también transmitirse de manera no sexual; por ejemplo, mediante la inyección de drogas con una aguja contaminada, a través de una transfusión de sangre contaminada, o de una mujer VIH-positiva a su feto o bebé.

5 Algunas (pero no todas las) ITS son curables. Una persona que completa el tratamiento adecuado dejará de tener la infección. Tomar las medidas preventivas apropiadas puede prevenir la re-infección.

6 El tratamiento apropiado con frecuencia puede reducir los síntomas y/o retrasar dramáticamente el avance de aquellas ITS que no pueden ser curadas (por ejemplo, el herpes, la infección con VIH y el VPH).

NOTA: VIH significa virus de la inmunodeficiencia humana. SIDA significa síndrome de inmunodeficiencia adquirida. VPH significa virus del papiloma humano. Ver las hojas informativas sobre Infecciones de Transmisión Sexual y sobre VIH y SIDA. 


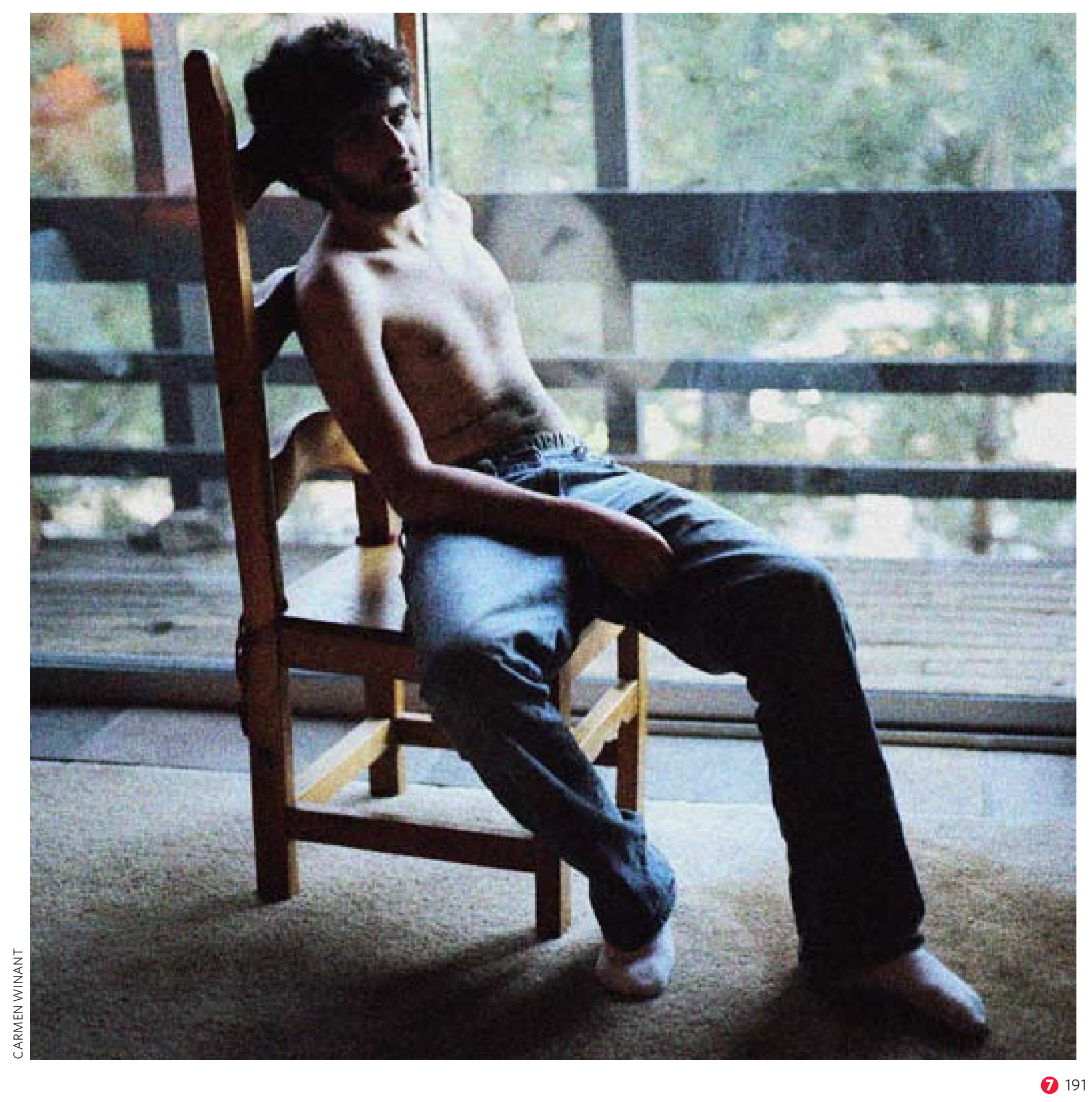




\section{métodos de protección contra las ITS y el VIH}

1 Todas las ITS, incluida la infección por VIH, son prevenibles.

2 Toda persona tiene el derecho de protegerse a sí misma contra las ITS. Hay varias formas de protegerse a sí misma y a la pareja contra las ITS. Esto es aplicable tanto si la pareja es del mismo sexo como si es del otro sexo.

3 La forma más segura de prevenir una ITS es no tener relaciones sexuales vaginales, orales o anales. Todas las personas tienen derecho a rehusarse a tener relaciones sexuales inseguras (o relaciones sexuales que no son deseadas por alguna razón). Muchas personas, sin embargo, no pueden ejercer o no ejercen este derecho. Esta situación es especialmente común en mujeres y niñas que carecen de poder para insistir en que sus parejas masculinas usen condones.

4 Ambos miembros de la pareja pueden estar de acuerdo en participar en formas de relación sexual que no conllevan el riesgo de la transmisión de la infección (como la masturbación mutua).

5 Ambos miembros de la pareja pueden estar de acuerdo en usar condones masculinos o femeninos. 
6 Ambos miembros de la pareja pueden practicar monogamia mutua. Esto significa no tener parejas sexuales fuera de su relación primaria y es también conocido como "ser fiel". Sin embargo, una persona puede ya estar infectada (incluso sin saberlo) o puede no ser completamente fiel. De ahí que prometer ser fiel no elimina la necesidad de practicar el sexo más seguro.

[Ver la siguiente sección; también ver la hoja informativa sobre VIH y SIDA.]

7 Una ITS común es el virus del papiloma humano (VPH). Hay muchas cepas de VPH; algunas causan verrugas genitales y otros conducen al cáncer - más comúnmente, en el cuello del útero. Vacunas pueden proteger a hombres y mujeres contra de muchas de estas cepas de VPH.

8 La circuncisión masculina ofrece alguna protección contra el VIH para los hombres, pero no representa protección directa para las mujeres.

- Tener prepucio en el pene parece facilitar que varios virus y bacterias — incluido el VIH — establezcan una infección en el hombre.

- Cuando los hombres están circuncidados, aún así pueden infectarse con el VIH y pueden infectar a sus parejas.

- Debido a que la circuncisión no proporciona beneficio directo para las mujeres y proporciona solamente protección parcial para los hombres, no elimina la necesidad de usar condones.

9 Es probable que las nuevas tecnologías de protección estén disponibles en el futuro. Conforme vaya apareciendo, las personas tienen derecho a aprender sobre esas tecnologías y tener acceso a ellas. 


\section{por qué la gente no usa protección y por qué la igualdad de género es clave en la lucha contra el SIDA}

1 En la vida real, muchas personas no usan protección contra las ITS.

2 Algunas personas no usan protección porque carecen de información habilidades, o acceso básico a los servicios.

Por ejemplo:

- Carecen de información exacta relacionada con la transmisión y prevención de las ITS, o sobre el uso apropiado del condón.

- No saben que hay condones para las mujeres (así como para los hombres). O pueden no tener acceso a los condones femeninos.

- Creen que su pareja no podría estar infectada.

- Creen que ellas mismas no están infectadas.

- Si tienen un encuentro sexual con una persona del mismo sexo, ya sea entre hombres o entre mujeres, pueden considerar que no se trata de relaciones sexuales "reales".

- Carecen de acceso a condones o se sienten avergonzadas de preguntar por ellos a un prestador de servicios, en una farmacia o en una tienda.

- Han tenido relaciones sexuales con alguien más y no están seguras de cómo decir a su pareja que uno o ambos pueden tener una ITS o VIH como resultado de ello.

- Se sienten avergonzadas para hablar sobre el uso del condón con una pareja o incómodas para ponerse un condón.

3 Algunas personas no usan protección porque no anticiparon que iban a tener relaciones sexuales.

- Se ven envueltas en el deseo del momento pero no tienen un condón ni masculino ni femenino a la mano.

- Pueden ser forzadas a tener relaciones sexuales. 


\section{Algunas personas no usan protección porque tienen sentimientos encontrados respecto a}

usar o hablar acerca del uso de los condones.

Por ejemplo:

- Algunas mujeres o parejas (incluidas aquellas en las que uno de los miembros de la pareja tiene una ITS incurable o VIH) están tratando de embarazarse.

- Las personas pueden tener la intención de usar protección, pero pueden también considerar que la relación sexual es más placentera sin el uso del condón.

- Las personas pueden tener la intención de proteger a sus parejas y su propia salud. Pero pueden ser renuentes a admitir (o incluso a preguntar sobre) la posibilidad de que alguno de los miembros de la pareja pueda haber tenido una relación sexual fuera de la pareja. En algunas circunstancias, por ejemplo:

- Revelar o preguntar sobre una relación externa conlleva un riesgo de conflicto o incluso de violencia

- Tales relaciones por fuera de la pareja pueden ser especialmente estigmatizadas (por ejemplo, un hombre casado que tenga relaciones sexuales con otro hombre, o una mujer que tenga relaciones extramaritales en un lugar en donde las normas de género condenen severamente tal actividad)

- El deseo de protección de una pareja puede estar en conflicto con las enseñanzas religiosas que se oponen al uso del condón. 


\section{Algunas personas no usan protección porque están en circunstancias de desigual poder}

social, incluida la desigualdad de género.

Por ejemplo:

- Algunas personas, especialmente las niñas, pueden sentirse presionadas por sus parejas para mostrar su amor al tener relaciones sexuales sin condón.

- Aún si los condones están disponibles, una persona puede sentirse presionada por su pareja para tener relaciones sexuales sin detenerse para ponerse un condón.

- Una brecha de edad significativa entre los miembros de la pareja puede dificultar que la persona más joven insista en el uso del condón.

- Dentro del matrimonio, las mujeres y las niñas frecuentemente se ven obligadas a tener relacione sexuales o a tener un hijo, aún cuando sientan que no es seguro.

- Las personas (tanto hombres como mujeres) a quienes se les paga para tener relaciones sexuales, pueden recibir un pago extra - o verse coaccionadas - para tener relaciones sexuales sin condón. Las niñas que aceptan favores o regalos de hombres mayores (amantes adinerados), pueden recibir ofertas de bienes materiales si aceptan tener relaciones sexuales sin condón.

- Iniciar una conversación sobre sexo o salud sexual puede considerarse inapropiado o tema tabú para las mujeres y las niñas.

- Algunas personas sienten que abordar el tema del condón implica sospecha de infidelidad sexual y puede desatar un conflicto, ira, o violencia. Tales reacciones resultan en grave daño para muchas mujeres en el mundo.

- En algunos lugares, los hombres que viven con el VIH creen equivocadamente que pueden curarse teniendo relaciones sexuales sin protección con una mujer virgen. Esta práctica es peligrosa para la niña y es un abuso extremo en contra de sus derechos humanos.

\section{El sexo forzado (además de ser un acto de violencia) con frecuencia ocurre sin el uso de} condones; por lo tanto, es más probable que conlleve el riesgo de VIH y otras ITS.

[Ver Unidad 2, páginas 70-71 y Unidad 3, páginas 106-107 para un tratamiento más amplio de la coerción sexual.]

7 A pesar de los obstáculos, millones de personas, incluida la gente joven, usan condones de manera correcta y efectiva. 


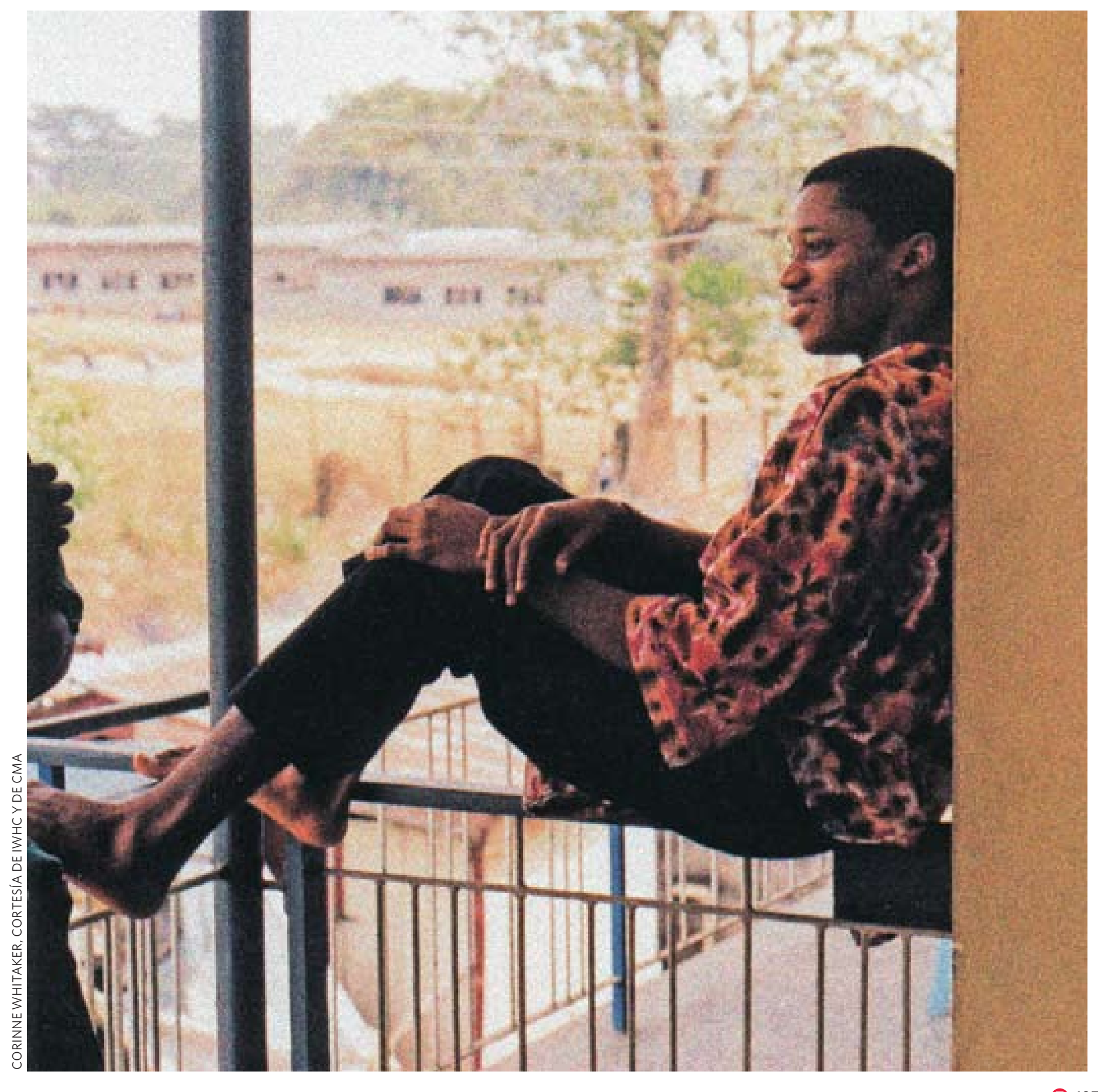

VER EL LIBRO DE ACTIVIDADES Actividad 47

género y uso del condón

Las y los estudiantes analizan las barreras (incluidas las normas de género) para el uso del condón, así como formas para superar estas barreras. Aprenden cómo usar un condón.

VER EL LIBRO DE ACTIVIDADES Actividad 48

iniciar una conversación sobre sexo y seguridad

Las y los estudiantes practican iniciando conversaciones sobre temas importantes de seguridad y salud sexual. 


\section{personas que viven con VIH y SIDA}

1 Todas las personas tienen derecho a saber su propia condición de $\mathrm{VIH}$ y obtener servicios de pruebas y consejería confidenciales. (Las personas también tienen derecho a no someterse a la prueba.)

2 Las personas que viven con ITS graves e incurables como la infección con VIH pueden vivir largo tiempo y mantener una vida relativamente normal, lo que incluye tener relaciones sexuales seguras, satisfactorias y solidarias. Sin embargo, para que esto suceda se requiere apoyo social y de atención a la salud, así como respeto a los derechos de las personas que viven con VIH o SIDA.

3 Las personas que viven con el VIH o SIDA necesitan consejería y apoyo para sentirse cómodas al hablar con otras personas sobre su condición de $\mathrm{VIH}$.

Este apoyo puede incluir:

- reuniones grupales con otras personas que viven con el VIH y SIDA;

- ayuda para informar y proteger a su(s) pareja(s) sexuales, incluidas las parejas actuales así como cualquier pareja anterior que pudiera haber sido infectada [ver siguiente sección];

- apoyo emocional, incluida la asistencia para hablar con miembros de su familia; y

- ayuda para asegurar que tengan la nutrición apropiada, tomar sus medicamentos y tener acceso a la atención.

VER EL LIBRO DE ACTIVIDADES Actividad 49

Aprendiendo de personas con VIH y SIDA

Las y los estudiantes escuchan la historia de una persona que es VIH-positiva.
4 Algunas personas sufren como resultado de revelar a sus parejas o miembros de su familia que son VIH-positivos. Muchos más encuentran que sus parejas y miembros de su familia son comprensivos y solidarios.

5 Cualquier persona que es VIH-positiva tiene derecho de obtener los servicios y tratamiento que necesite.

- La atención puede incluir, por ejemplo, acceso a medicamentos; atención médica especial durante el embarazo o enfermedad; y servicios sociales con apoyo de consejería continuo.

- El tratamiento médico y atención para las personas que viven con el VIH y SIDA son costosos. El apoyo de gobiernos y donantes internacionales es esencial para la gente que vive en condiciones de pobreza y que necesitan obtener atención. 
6 Las personas que viven con el VIH y SIDA tienen derecho a vivir libres de estigma y discriminación. Desafortunadamente, muchas veces este derecho no es respetado.

Por ejemplo:

- En algunos países, a las personas que viven con el VIH o SIDA se les impide el acceso al empleo, vivienda o a satisfacer otras necesidades básicas.

- A algunas mujeres que viven con el VIH o SIDA se les ha negado injustamente el acceso a los servicios de salud reproductiva.

\section{En cierto modo, las familias y comunidades están también "viviendo con" el VIH y} SIDA. Esto es especialmente cierto cuando una relativamente alta proporción de personas se infectan con el virus.

- En algunos poblados, muchas personas que generan ingresos se enferman al grado de no poder trabajar.

- Millones de personas (especialmente mujeres y niñas) cuidan a miembros de sus familias que viven con el VIH.

- En algunos entornos, no se permite a las mujeres que hereden propiedades o reciban prestaciones del estado cuando sus esposos mueren. Como resultado, el perder al esposo debido al SIDA puede significar la pérdida de la vivienda y los medios de subsistencia.

- Millones de niñas y niños han quedado en la orfandad porque uno o ambos padres han muerto debido al SIDA.

- La gente joven debe arreglárselas con la realidad del VIH a la vez que busca mantener una experiencia positiva respecto al sexo y la sexualidad.

8 En todo el mundo hay grupos que trabajan con la finalidad de proteger los derechos de las personas que viven con el VIH y SIDA, para apoyar a las comunidades a que hagan frente a la epidemia y para impulsar los esfuerzos de prevención.

Algunas de sus actividades incluyen:

- proporcionar apoyo y hacer trabajo de advocacy para apoyar a las personas que viven con el VIH o SIDA, así como a sus familias;

- proporcionar asistencia a niñas y niños que han perdido a uno o ambos padres debido al SIDA;

- hacer labor de advocacy para un mayor acceso al tratamiento;

- aumentar el nivel de conciencia respecto al VIH y SIDA y las formas de prevenir la transmisión de la infección; y

- hacer labor de advocacy a favor de la investigación y experimentación de otras formas de protección contra el virus.

\section{PUNTOS PARA REFLEXIÓN}

¿Qué clase de estigma o discriminación pueden enfrentar las personas que viven con el VIH o SIDA para encontrar parejas románticas, sexuales y para casarse? ¿Al convertirse en padres? ¿Al buscar vivienda o empleo?

¿Qué diferencia pueden hacer las leyes contra la discriminación en la protección de los derechos de las personas

que viven con el VIH o SIDA? ¿Qué diferencia pueden hacer las campañas educativas?

¿Cómo podemos asegurar que la gente joven que vive en áreas con altas tasas de VIH pueda crecer con una experiencia positiva respecto al sexo y la sexualidad? 


\section{derechos y responsabilidades relacionados con la prevención de las ITS y el VIH}

1 Las sociedades y gobiernos tienen responsabilidades de proporcionar servicios de salud, respetar la confidencialidad y proteger a toda la gente contra el estigma y la discriminación que resulta de su condición de salud. Cada uno de nosotros tiene derecho a obtener estos servicios y protecciones.

2 Dentro de nuestras relaciones sexuales, cada uno de nosotros tiene derecho a protegerse a sí mismo de las consecuencias dañinas de la actividad sexual - incluidas las infecciones con ITS y VIH, así como el embarazo no planeado.

3 Dentro de nuestras relaciones sexuales, cada uno de nosotros tenemos la responsabilidad de proteger a nuestras parejas de las consecuencias dañinas para la salud, incluidas las ITS, VIH y el embarazo no planeado. La responsabilidad de proteger a nuestras parejas se vuelve particularmente importante cuando las posibles consecuencias son muy graves.

4 Muchas personas informan a sus parejas sexuales que son (o tienen la sospecha de ser) VIH-positivas, aún cuando decírselo no sea fácil.

VER EL LIBRO DE ACTIVIDADES Actividad 50

¿qué tienes que decir? ¿qué te gustaría saber?

A través del diálogo y la escritura creativa, las y los estudiantes

consideran qué responsabilidad tienen las personas de revelar su condición de VIH a una pareja sexual.
Algunas de las razones por las que las personas comparten esta información incluyen:

- Quieren proteger a su pareja.

- Desean que una pareja previa les hubiera revelado su condición a ellas.

- Quieren recibir apoyo emocional de su pareja.

- Les preocupa que su pareja pueda tener conocimiento de su condición a partir de un prestador de servicios de salud o de alguien más. 
5 La mayoría de la gente siente que tiene el derecho de saber si su pareja sexual es VIH-positiva, aún si están usando condones.

- Es posible que ellos sientan que su relación sexual debe ser basada en franqueza y honestidad, incluyendo este asunto.

- Algunas personas pueden elegir tener relaciones sexuales, a pesar del estatus de VIH de su pareja, mientras que otras no quieren.

- Algunas personas pueden querer explorar diferentes enfoques a la intimidad sexual que no implica un riesgo de transmisión (ver pagina 192).

6 Sin embargo, en realidad, algunas personas no le dicen a sus parejas sexuales que están (o que sospechan ser) VIH-positivas.

Por ejemplo:

- Ellos sienten que no tienen que decirle a sus parejas sexuales acerca de su estatus de VIH si van a usar condones, ya que reducen en gran medida el riesgo de transmisión del virus.

- No saben cómo discutir el asunto.

- Tienen miedo de la reacción de su pareja. Por ejemplo, temen que su pareja puede acusarles de infidelidad sexual, que tal vez se vuelvan violentos, o que los abandonaran.

- Temen que otras personas conocerán su estatus de VIH, lo cual podría resultar en la estigmatización y la discriminación.

- No tienen la preocupación adecuada sobre la salud de su pareja sexual. Ellos piensan, erróneamente, que no van a infectar a su pareja.

- Incorrectamente creen que no infectarán a su pareja.

7 Un consejero o profesional en salud puede proveer apoyo y orientación acerca de cómo hablar con su pareja sobre su estatus de $\mathrm{VIH}$. 


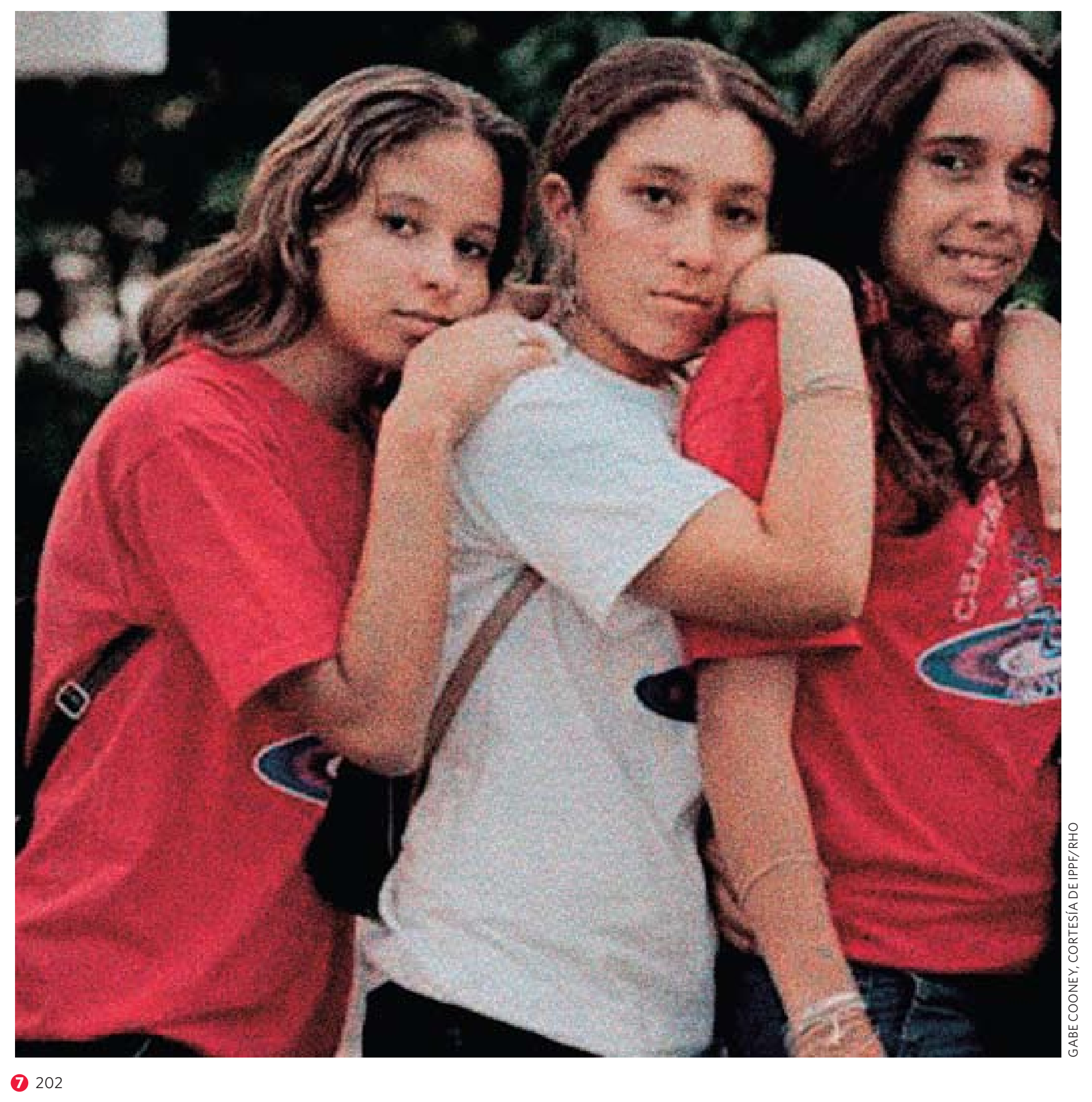




\section{infecciones del tracto reproductivo (ITR)}

1 Infecciones del tracto reproductivo (ITR) es un término general que se usa para identificar infecciones que afectan los órganos reproductivos. Las ITR tienen tres principales tipos de causas.

[Ver hoja informativa sobre Infecciones del Tracto Reproductivo.]

2 Algunas ITR se transmiten a través de las relaciones sexuales. (En estos casos, generalmente se les llama infecciones de transmisión sexual, o ITS.)

[Ver sección previa, que inicia en la página 189.]

3 Algunas ITR resultan de un desequilibrio en los organismos que están presentes normalmente en el tracto genital.

- Este tipo de ITR es mucho más común en las mujeres que en los hombres.

- Este tipo de ITR a veces es causado por prácticas que son innecesarias (como la ducha vaginal) o incluso dañinas (como insertarse sustancias que secan la vagina), o como un efecto secundario por usar ciertos medicamentos.

4 Algunas ITR son transmitidas o propagadas por ciertos procedimientos médicos y tratamientos.

- Este tipo de ITR es mucho más común en las mujeres que en los hombres.

- Este tipo de ITR puede resultar del uso de instrumentos médicos que no sean estériles (que no hayan sido limpiados apropiadamente) o por empujar una infección existente hacia arriba del tracto reproductivo durante un procedimiento médico (por ejemplo, durante la inserción de un DIU). 
5 Las ITR pueden causar síntomas como comezón o secreción vaginal.

6 Muchas ITR son tratadas fácilmente y curadas, especialmente si son diagnosticadas de manera temprana. Si se dejan sin tratamiento, algunas pueden tener graves consecuencias, incluida la infecundidad o incluso la muerte (en el caso de enfermedad inflamatoria pélvica).

7 Las mujeres tienen mayor probabilidad que los hombres de sufrir graves consecuencias (incluida la infecundidad) debido a una ITR no transmitida sexualmente.

8 En entornos en donde la prevalencia de ITR es extremadamente alta, muchas veces se carece del conocimiento de tales infecciones y su tratamiento.

9 En algunos países, las mujeres han exigido que las ITR se consideren como una seria preocupación de salud. Han hecho llamados para que se invierta en educación y servicios clínicos relacionados con las ITR. 


\section{PART 2: \\ DECISIONES SOBRE LA \\ PROPIA FECUNDIDAD: \\ ANTICONCEPCIÓN Y ABORTO}

[Las personas tienen] los mismos derechos a decidir libre y responsablemente el número de sus hijos y el intervalo entre los nacimientos y a tener acceso a la información, la educación y los medios que les permitan ejercer estos derechos (Artículo 16.e, CEDAW, 1979; Principio 8, Programa de Acción de la CIPD, 1994). 


\section{sobre la anticoncepción}

Refiérase a la hoja informativa sobre Métodos Anticonceptivos para desarrollar un programa de estudio detallado.
1 Una persona (o pareja) que pretende tener un coito heterosexual pero que no desea un embarazo, puede usar un anticonceptivo o participar en una actividad sexual diferente al coito.

2 La anticoncepción puede definirse como cualquier método usado para evitar el embarazo. Diferentes métodos se usan de diferentes maneras y en diferentes momentos. [Ver sección siguiente.]

3 El uso de anticonceptivos permite que mucha gente goce de sus vidas sexuales sin tener que preocupares por un embarazo no deseado. Los condones masculinos y femeninos también permiten que las personas gocen de las relaciones sexuales con menor preocupación acerca de las infecciones de transmisión sexual.

- El uso de anticonceptivos permite que muchas personas tengan un mayor control sobre sus cuerpos, sus relaciones y su vida social y económica en general.

- Conversar acerca de los anticonceptivos y usarlos puede fomentar la confianza y comodidad mutuas.

- Millones de personas en todo el mundo usan anticonceptivos.

4 La mayoría de los gobiernos y de las personas reconocen los beneficios de la anticoncepción y el derecho a usarla.

- La mayoría de los gobiernos y servicios de salud proporcionan servicios anticonceptivos a cualquier persona que los solicite (sin importar su edad, género o estado civil); unos cuantos servicios no respetan este derecho básico y rehúsan atender a las y los adolescentes; a las personas solteras; o (en el caso de las mujeres) a las que no tienen el consentimiento del esposo.

- Algunos grupos religiosos se oponen a todas las formas de anticoncepción, pero la mayoría de grupos y líderes religiosos apoyan el derecho a usar un anticonceptivo. 
5 Los acuerdos internacionales protegen el derecho de las personas y de las parejas a controlar su propia fecundidad. Estos acuerdos también alientan a los niños y hombres a compartir la responsabilidad para evitar los embarazos no planeados.

6 En el pasado, muchos hombres esperaban que las mujeres asumieran la total responsabilidad para evitar el embarazo. En la actualidad, muchos hombres comparten esa responsabilidad.

Por ejemplo, un hombre puede compartir tal responsabilidad al:

- abstenerse de tener relaciones sexuales sin anticoncepción;

- comunicarse con su pareja femenina antes de tener relaciones sexuales;

- educarse a sí mismo acerca de los diferentes métodos anticonceptivos;

- usar condones correcta y consistentemente;

- cuando sea apropiado, usar otros métodos masculinos como el retiro o la vasectomía;

- acompañar a su pareja femenina a la clínica de planificación familiar; y

- apoyar a su pareja femenina en el uso de su método anticonceptivo.

\section{Algunas personas (incluso si no quieren embarazarse) no usan un anticonceptivo} porque carecen de información exacta o completa.

Por ejemplo:

- Las personas pueden no entender el riesgo que tienen de embarazarse.

- Muchas personas carecen de conocimientos del período fértil durante el ciclo menstrual de una mujer o niña.

- Muchas personas carecen de información exacta sobre los diferentes métodos anticonceptivos que pueden estar disponibles y ser aceptables para ellas, o sobre dónde obtener los anticonceptivos.

- Las y los prestadores de servicios pueden tener información inexacta o desactualizada sobre cuáles métodos son apropiados para que usen las personas adolescentes. 
8 Algunas personas (incluso si no desean un embarazo) no usan anticonceptivos porque carecen de acceso a servicios en donde se puedan sentir cómodas.

Por ejemplo:

- Algunas se preocupan por el costo, privacidad y confidencialidad para encontrar y pagar por los servicios.

- Muchas personas no tienen acceso a una clínica o farmacia donde puedan comprar anticonceptivos.

- Muchas personas - especialmente las pertenecientes a minorías étnicas o raciales, la gente joven soltera y las personas que viven en condiciones de pobreza — no son tratadas respetuosamente por las y los prestadores de servicios.

9 Algunas personas (incluso si no desean un embarazo) no usan anticonceptivos debido a barreras personales o culturales, incluida la desigualdad de género.

- Las normas comunitarias sobre género y sexualidad hacen que mucha gente - especialmente, pero no únicamente las niñas - se sienta avergonzada de admitir que está planeando tener relaciones sexuales, o de hablar sobre anticoncepción con su pareja sexual.

- Algunas personas creen que su pareja está tomando la responsabilidad por la anticoncepción.

- Algunas personas se oponen a la anticoncepción debido a las creencias que han adoptado de su familia, comunidad o líderes religiosos.

- Muchas parejas experimentan presión social para producir un hijo; la presión sobre las mujeres para probar su fecundidad y tener hijos puede ser intensa.

- Muchas personas - especialmente las mujeres, pero no solamente ellas — son coaccionadas para tener relaciones sexuales que no estaban planeando tener.

- Uno de los miembros de la pareja puede oponerse a usar anticonceptivos y puede recurrir a la presión, amenazas o engaño para evitar usar uno.

\section{Algunas personas (incluso si no desean un embarazo) no usan anticonceptivos} debido a que no han encontrado un método que deseen o puedan usar de manera segura. Por ejemplo, pueden estar preocupados acerca de los efectos secundarios (ya sean reales o percibidos) u otras características de un método anticonceptivo. 


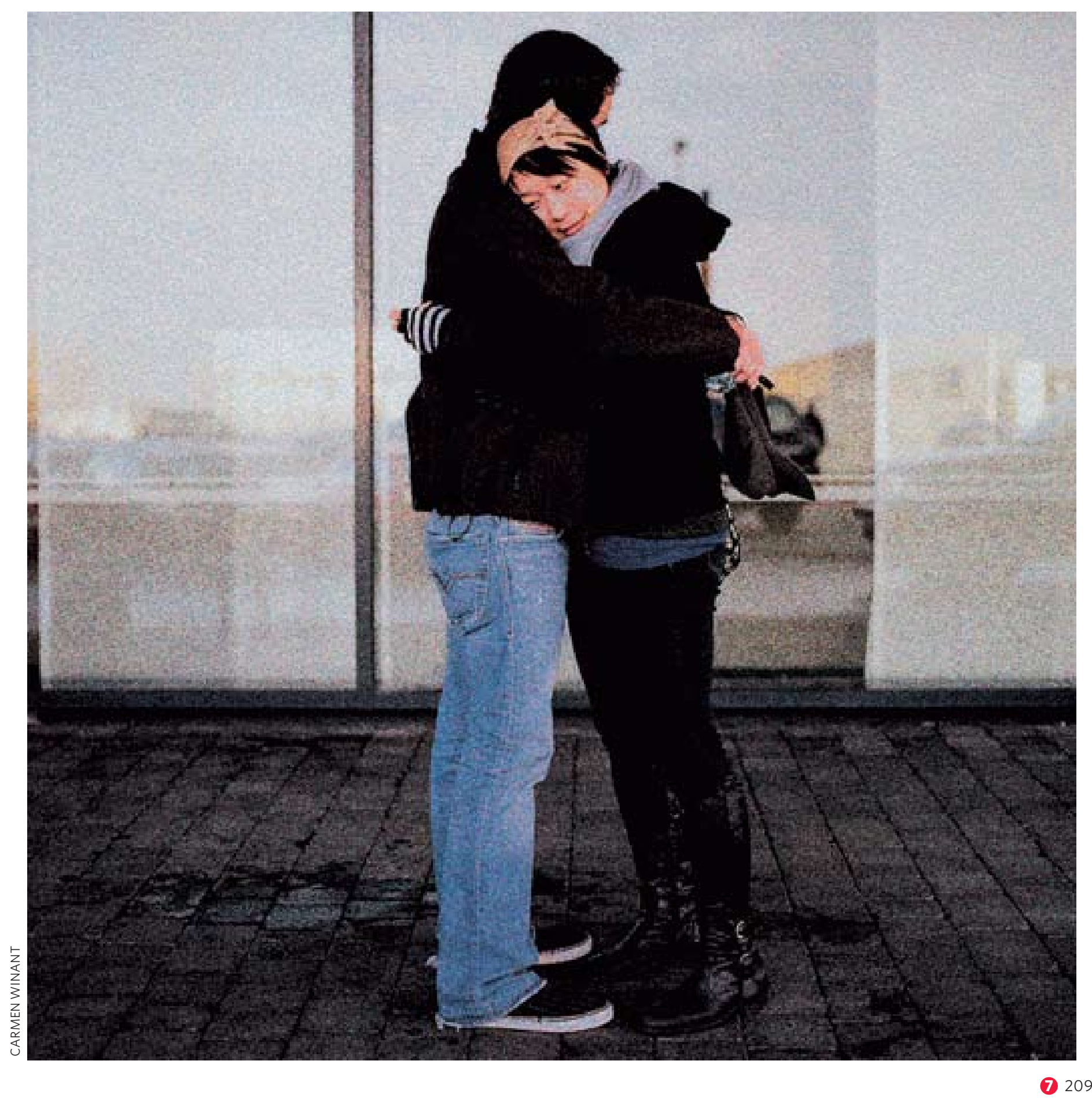




\section{diferentes métodos anticonceptivos}

Refiérase a la hoja informativa sobre Métodos Anticonceptivos para desarrollar un currículo detallado.
1 La mayoría de los métodos anticonceptivos son para ser usados por mujeres; solamente unos cuantos métodos son usados por el hombre. Hay muchos métodos de dónde escoger. Cada persona tiene el derecho a dar su consentimiento libre e informado en relación con el método a usar. Muchas parejas cooperan en la selección y uso de su método.

2 Ningún método anticonceptivo es perfecto; y cada método tiene sus propias características. Algunos métodos conllevan restricciones médicas.

- Solamente dos métodos, el condón masculino y el condón femenino, protegen contra el VIH.

- Algunos métodos, pero no todos, pueden afectar el placer o desempeño sexual.

- Algunos métodos son fáciles de obtener. Otros requieren una visita a una clínica de salud y pueden involucrar un examen físico.

- Los métodos varían en su efectividad al prevenir el embarazo.

- Algunos métodos conllevan riesgos de efectos secundarios para la salud de las personas usuarias.

- El uso de algunos, pero no todos, los métodos puede detenerse y volverse a iniciar fácilmente.

- Algunos métodos son más satisfactorios para las personas que tienen relaciones sexuales de manera relativamente infrecuente.

- Los métodos varían en su costo y disponibilidad.

3 Con frecuencia, las personas experimentan con diferentes métodos para determinar cuál les funciona mejor.

- Un prestador de servicios de salud puede ofrecer información sobre los beneficios, desventajas y efectos secundarios de los diferentes métodos.

- Si una persona no se siente cómoda con un método, ella o él pueden cambiar a un método diferente. 
4 Algunas personas eligen métodos anticonceptivos que ofrecen la mayor protección contra la infección. Estos métodos se insertan o colocan cada vez que la pareja tiene relaciones sexuales. Estos se llaman "métodos de barrera" porque crean una barrera entre el óvulo y el esperma, haciendo que sea imposible la fecundación.

- Los condones (masculinos y femeninos) ofrecen protección tanto contra el embarazo como contra el VIH. También protegen contra varias ITS, incluidas algunas que pueden dañar la fecundidad futura.

- En muchos lugares, la gente joven puede obtener condones gratuitamente o puede comprarlos en farmacias o en otro tipo de comercios.

- Algunas personas consideran que los condones reducen su placer sexual. Otras no piensan así, o sienten que este inconveniente es compensado por el hecho de tener protección contra un embarazo no deseado y las ITS (incluido el VIH).

- Para obtener protección extra, muchas parejas usan condones además de otro método anticonceptivo.

- Otros métodos de barrera, como el diafragma y el tapón cervical, son usados por las mujeres. Todavía no se sabe con certeza si el tapón o el diafragma ofrecen alguna protección contra las infecciones.

\section{Algunas personas eligen métodos anticonceptivos (como "la píldora", implantes} hormonales, hormonas inyectables, parches hormonales, el anillo vaginal y el DIU) que son especialmente efectivos en la prevención del embarazo.

- Estos métodos no protegen contra las infecciones de transmisión sexual. Combinar el uso de uno de estos métodos con un condón masculino o femenino puede ofrecer una mayor protección tanto contra el embarazo como con las infecciones de transmisión sexual, incluido el VIH.

- Estos métodos tienden a tener más efectos secundarios. Por ejemplo, en algunas mujeres ciertos métodos hormonales reducen el interés en las relaciones sexuales.

- Estos métodos tienen más complicaciones potenciales relacionadas con la salud, aunque pueden tener también algunos beneficios para la salud.

- El uso de estos métodos puede ser más conveniente.

- Puede ser más fácil para las mujeres usar estos métodos, sin importar la participación activa de sus parejas; algunos pueden ser usados incluso sin el conocimiento de su pareja. 
6 Con el fin de evitar un embarazo no planeado, algunas mujeres aprenden técnicas para identificar cuáles días en su ciclo menstrual y ovulación tienen mayor probabilidad de ser fecundas (capaces de embarazarse). Hay una variedad de estas técnicas, las cuales en grupo reciben el nombre de "métodos basados en el conocimiento de la fecundidad". Por ejemplo, una mujer puede aprender a calcular sus días fecundos más probables con base en sus ciclos menstruales pasados. Ella puede observar también los cambios en su propio cuerpo, incluidos un cambio en la temperatura corporal y en la textura de la secreción mucosa de la vagina. [Ver la hoja informativa sobre el Ciclo Menstrual.]

- Aprender a identificar el período fértil toma tiempo; la mujer tiene que aprender acerca del ciclo menstrual y practicar la observación y registro de los cambios cíclicos en su propio cuerpo.

- Durante los días fértiles de su ciclo menstrual y ovulación, las parejas pueden usar un método anticonceptivo como el condón, o pueden evitar tener coito vaginal. [Ver sección previa sobre el Sistema Reproductivo.]

- El ciclo menstrual y de ovulación de cada mujer es diferente. Las hormonas, enfermedades y otros actores con frecuencia pueden perturbar la regularidad del ciclo.

- Las adolescentes más jóvenes con frecuencia tienen ciclos irregulares, lo que dificulta el uso de estos métodos de manera efectiva.

- Estos métodos no protegen contra las ITS o VIH.

- Muchas parejas encuentran que usar estos métodos de manera efectiva es difícil o inconveniente.

7 Algunas parejas evitan el embarazo poniéndose de acuerdo para que el hombre retire el pene de la vagina de su pareja antes de eyacular (tener un orgasmo y liberar el semen). A esto se le llama "retiro".

- Si se usa de manera apropiada y consistente, el retiro es efectivo para evitar el embarazo.

- El uso efectivo del retiro requiere de un alto grado de control y compromiso por parte del hombre. Por esta razón, las parejas que tratan de usar el retiro tienen más embarazos no planeados que las parejas usuarias de muchos otros métodos. El uso apropiado y consistente del retiro es frecuentemente un reto para la gente joven.

- El retiro no proporciona protección efectiva contra el VIH (u otras ITS). 
8 Algunas personas eligen la esterilización, un método anticonceptivo quirúrgico que tiene que ser considerado como permanente. Tanto las mujeres como los hombres pueden ser esterilizados.

9 Una mujer puede obtener protección contra el embarazo después de haber tenido una relación sexual, usando un método llamado "anticoncepción de emergencia".

[Ver la hoja informativa sobre Anticoncepción de Emergencia.]

- La anticoncepción de emergencia es útil en casos en los que la pareja no usó un anticonceptivo, experimentó una falla del método (por ejemplo, como resultado de un condón roto), o cuando la mujer se vio forzada a tener relaciones sexuales.

- La anticoncepción de emergencia es bastante efectiva por hasta cinco días después de tener las relaciones sexuales sin protección. Pero funciona mejor mientras más pronto se use durante ese período.

- La forma más común de anticoncepción de emergencia contiene una dosis específica de hormona usada en muchos anticonceptivos orales. Es frecuente que las píldoras de anticoncepción de emergencia se empaquen específicamente para este propósito. En algunos lugares, el método está disponible sin receta médica.

- Insertar un DIU dentro de los cinco días posteriores a la relación sexual es otra opción para la anticoncepción de emergencia.

- La anticoncepción de emergencia no es un método de aborto. No terminará un embarazo establecido.

\section{Algunas veces los anticonceptivos fallan.}

- Cuando lo hacen, algunas mujeres eligen continuar el embarazo no planeado. [Ver Unidad 6, páginas 174-177.]

- Otras mujeres eligen terminar el embarazo. [Ver la sección siguiente.]

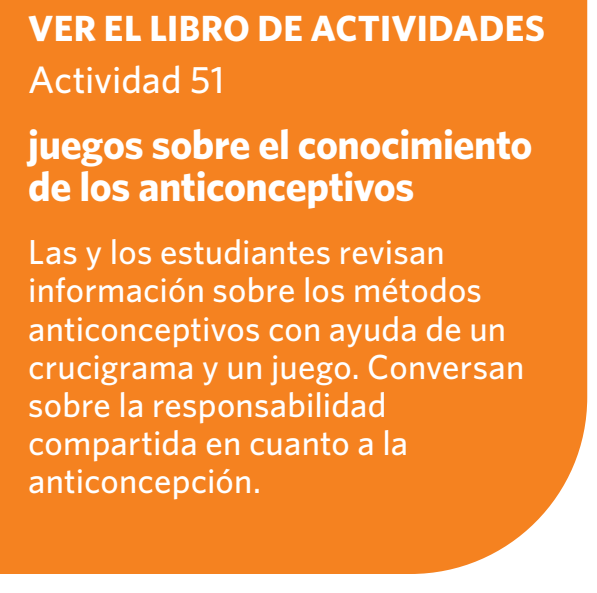

VER EL LIBRO DE ACTIVIDADES Actividad 51

juegos sobre el conocimiento de los anticonceptivos 


\section{embarazo no planeado y aborto}

Los acuerdos internacionales afirman la necesidad de reconocer y afrontar las consecuencias que tienen para la salud los abortos peligrosos (Párrafo 106j, Plataforma para la Acción de la CCMM, 1995); y, en los casos en que el aborto no es contrario a la ley, los abortos deben realizarse en condiciones adecuadas (Párrafo 8.25, Programa de Acción de la CIPD, 1994; Párrrafo 106k, Plataforma para la Acción de la CCMM, 1995).

1 Millones de mujeres y niñas experimentan embarazos no planeados. Estos embarazos ocurren por muchas razones: porque un anticonceptivo no estuvo disponible, porque no fue usado, porque fue usado incorrectamente, o porque fue usado correctamente pero falló.

2 Cada año, entre 40 y 50 millones de mujeres y niñas deciden buscar un aborto (para terminar un embarazo).

3 Las mujeres y niñas tienen abortos por muchas razones.

Por ejemplo:

- No pueden costear o manejar la crianza de un niño (ya sea que se trate de su primer hijo o de otro hijo).

- No quieren convertirse en madres en el momento que ocurre el embarazo.

- Desean terminar su educación académica.

- La relación con su pareja se está volviendo difícil, o no están en una relación estable y no desean criar un hijo por sí solas.

- El embarazo amenaza su salud física o mental.

- Se embarazaron como resultado de una relación sexual que fue forzada, o bajo coerción. 
4 Aún en situaciones en las que una mujer o pareja desea continuar con un embarazo, éste puede terminar en un aborto por varias razones.

Por ejemplo:

- El embarazo puede amenazar la salud física o mental de la mujer.

- Factores genéticos, de comportamiento o ambientales pueden causar serios riesgos médicos (incluso la muerte) para el feto.

- La pareja no se siente feliz con el sexo del feto. Este sentimiento ocurre principalmente en lugares en donde la sociedad injustamente asigna un mayor valor a los hijos que a las hijas. [Ver hoja informativa sobre Selección de Sexo.]

- Algunas mujeres o niñas se ven presionadas para tener un aborto debido a su situación personal o económica, su condición de salud, o por otras razones. Tal presión puede provenir de otra persona (por ejemplo, uno de los padres, novio o prestador de servicios). En países con políticas de población coercitivas, el gobierno puede presionar a las mujeres a tener abortos.

5 Existen varios métodos para realizar un aborto seguro. Dependiendo de la etapa del embarazo y de la capacidad de las instalaciones del prestador de servicios de salud, los métodos de aborto incluyen un procedimiento quirúrgico o medicación.

[Ver hoja informativa sobre el Aborto.]

6 El aborto es un procedimiento simple y seguro cuando se proporciona bajo condiciones apropiadas. Éstas incluyen contar con un prestador de servicios capacitado, equipo apropiado y estéril y acceso a tratamiento temprano para prevenir complicaciones potenciales.

- En general, es mucho más probable que el aborto sea seguro cuando es legal.

- Las condiciones bajo las cuales se proporciona típicamente el aborto varían ampliamente de lugar a lugar. A nivel global, poco más de la mitad de todos los abortos se proporcionan bajo condiciones seguras. 
7 Un gran número de personas y de gobiernos apoyan el acceso al aborto legal y seguro.

Las personas y los gobiernos pueden apoyar el acceso legal al aborto seguro porque:

- creen que las personas deben tener acceso a todos los procedimientos médicos seguros;

- se dedican a reducir la mortalidad materna, incluidas las muertes que resultan de los abortos inseguros;

- creen que las mujeres tienen derecho a controlar sus propias vidas y que la capacidad de controlar su fecundidad es una parte importante de ese derecho;

- creen que las personas deben poder gozar su intimidad y placer sexual sin reproducirse;

- les preocupa el crecimiento poblacional y quieren que las mujeres tengan acceso a todos los métodos posibles para controlar su fecundidad; $y$

- les preocupan los efectos económicos que resultan del aborto inseguro (por ejemplo, el costo de prestar atención de emergencia para mujeres y niñas que sufren complicaciones).

Las personas y gobiernos pueden oponerse al acceso al aborto porque:

- tienen creencias religiosas o personales que lo prohíben;

- creen que las mujeres no deben tener control sobre sus propias vidas y fecundidad;

- creen que las relaciones sexuales no deben gozarse separadamente de la reproducción; y

- equivocadamente piensan que hacer que el aborto sea legal y seguro aumentará la promiscuidad o aumentará las tasas de aborto.

\section{VER EL LIBRO DE ACTIVIDADES}

\section{Actividad 52}

pongámonos en su lugar: la decisión de terminar un

\section{embarazo}

Las y los estudiantes leen estudios de caso y conversan acerca de las razones por las que las mujeres

buscan los abortos. 
8 Casi todos los países en el mundo han aprobado leyes que permiten los abortos bajo circunstancias específicas.

- En algunos lugares, las mujeres tienen derecho al aborto a solicitud, usualmente hasta un número especificado de semanas de embarazo.

- En otros lugares, el aborto se permite solamente bajo circunstancias específicas; por ejemplo, para salvar la vida de la mujer, en casos de violación o incesto, o en otras situaciones o condiciones.

- Las leyes de aborto son un tema de continuo debate y están sujetas a cambios en muchos países.

9 Cada hora, aproximadamente ocho mujeres y niñas mueren (y doscientas quedan infecundas) simplemente porque los servicios de aborto seguro no están disponibles o accesibles. Estos trágicos resultados pueden evitarse fácilmente.

- Aunque el aborto es un procedimiento simple y seguro cuando se realiza bajo circunstancias apropiadas, cerca de la mitad de los abortos se realiza bajo circunstancias inseguras.

- El aborto inseguro es un muy grave problema de salud pública en muchas partes del mundo. Afecta a mujeres y niñas de todas las condiciones sociales, pero especialmente a quienes viven en condiciones de pobreza.

\section{PUNTOS PARA REFLEXIÓN}

En donde el aborto está restringido legalmente, algunos médicos arriesgan sus carreras para proporcionar abortos seguros a bajo costo. ¿Por qué creen ustedes que hacen eso?

Hacer que el aborto sea legal y seguro ha sido una prioridad para las y los activistas que trabajan por la salud de las mujeres en muchos países en donde el procedimiento está restringido. ¿Por qué piensan que este tema es una preocupación tan importante?

Algunos activistas que trabajan a favor del derecho a tomar decisiones reproductivas han dicho "si fueran los hombres los que se embarazaran, el aborto sería seguro, legal y accesible". Dado que eso no es posible, ¿este planteamiento es útil?

Si una niña decide por su cuenta - en contra de la preferencia de su novio - continuar con un embarazo no planeado, ¿qué tanta responsabilidad personal y financiera, si la hay, debe tener el novio para apoyar al hijo? ¿Y por cuántos años? 


\section{ADVOCACY PARA}

LA SALUD SEXUAL,

DERECHOSE

IGUALDAD DE

GÉNERO 


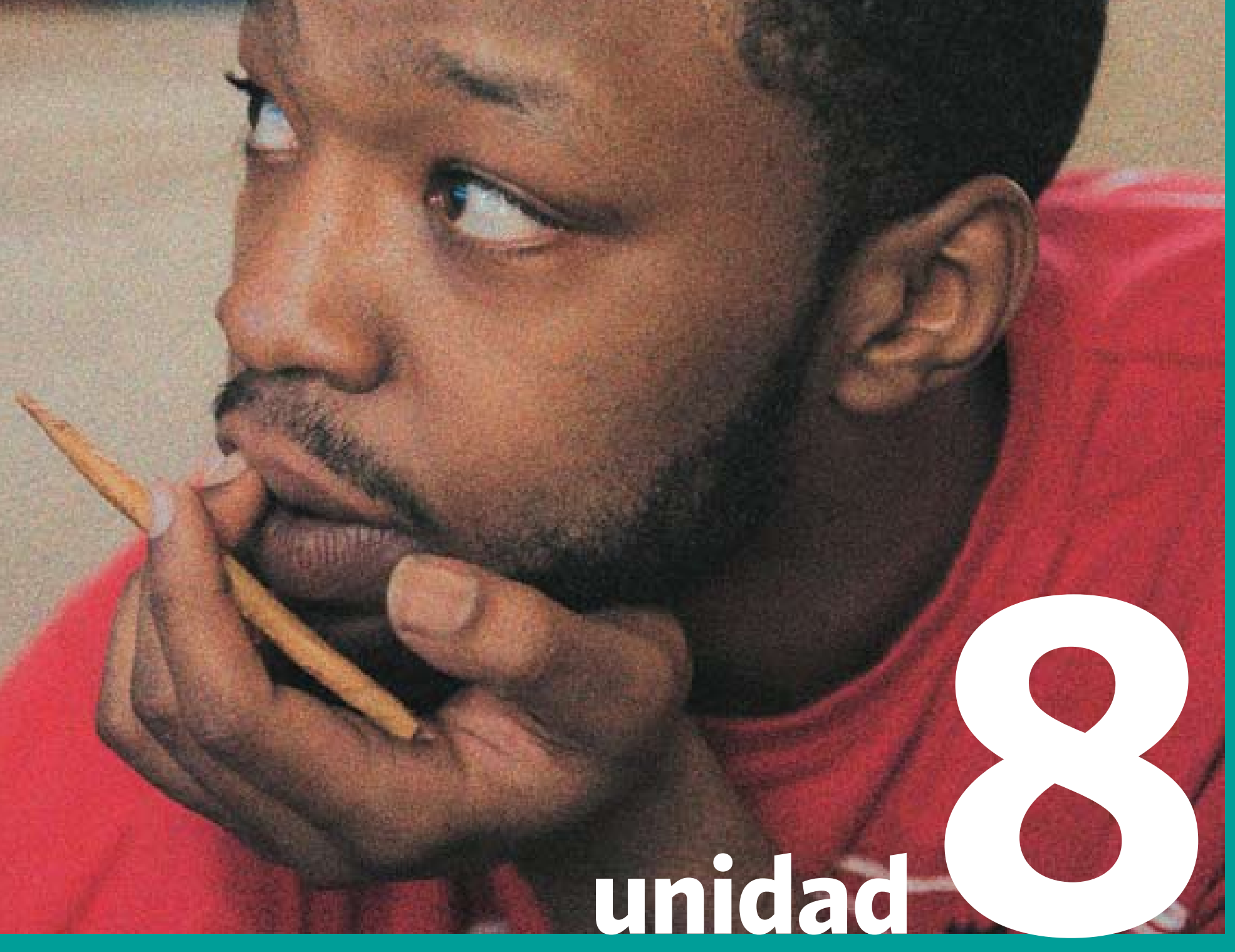




\section{visión general}

Este modulo especial permite a las y los educadores apoyar a sus estudiantes a través experiencias de aprendizaje práctico en sus propias vidas, escuelas y comunidades. Estas experiencias se enfocan en lograr un cambio en las áreas de salud sexual (incluidos el VIH y el SIDA), derechos humanos e igualdad de género. Las y los estudiantes pueden reflexionar sobre sus propios comportamientos. Pueden discernir lo que consideran justo o injusto. Y pueden tomar medidas - ya sean grandes o pequeñas - para hacer una diferencia en sus propias vidas y en las vidas de otras personas. Este tipo de compromiso personal y cívico ayuda a empoderar a las personas como ciudadanos responsables y ayuda a promover una cultura democrática. 


\section{ADVOCACY PARA LA SALUD SEXUAL, DERECHOS E IGUALDAD DE GÉNERO}

Esta unidad le ayudará a orientar a sus estudiantes para emprender proyectos con actividades prácticas. Aún si sus estudiantes no son capaces de conducir un proyecto de advocacy por sí mismos, usted puede usar la primera parte de esta unidad para presentar los temas de advocacy y cambio social a sus estudiantes.

Utilice el material en las unidades precedentes de este libro como referencia, de tal forma que usted pueda ayudar a sus estudiantes a pensar y aprender sobre diferentes temas.

Aunque esta unidad destaca temas especiales (incluida la igualdad de género, los derechos de las personas que viven con el VIH y el SIDA, así como la violencia), puede aplicarse a una amplia gama de proyectos de acción social.

Familiarícese con al menos un esfuerzo de advocacy en su zona. Ustedes pueden aprovechar esta información para exponer ejemplos concretos sobre por qué y cómo las personas trabajan para el cambio social.

Este módulo incluye una serie de "preguntas para reflexión" que sus estudiantes pueden encontrar complicadas o personalmente desafiantes. Tenga cuidado de seleccionar preguntas que sean apropiadas para su audiencia.

Busque estímulo y consejo de otras personas para guiar a sus estudiantes a través de este módulo.

\section{SI USTED VA A ENSEÑAR EL MÓDULO “TOMAR ACCIÓN: MÓDULO DE APRENDIZAJE BASADO EN PROYECTOS":}

Aliente a sus estudiantes a comenzar con prudencia. Recuérdeles que el cambio es importante a cualquier nivel. Ayúdeles a comprender cómo sus pequeñas acciones pueden vincularse con movimientos más grandes.

Aliente a sus estudiantes a trabajar en equipos y asegúrese de que los equipos dan a cada quien la oportunidad de participar y sentirse involucrado.

Recuerde: Su responsabilidad primaria es mantener seguros a sus estudiantes. Aunque el cambio a veces requiere de pasos audaces, incluso los pasos pequeños pueden parecer amenazantes para otras personas en la comunidad. Conforme sus estudiantes diseñan sus proyectos, haga sus propias averiguaciones entre las y los líderes de su institución o comunidad sobre cualquier resistencia potencial para los planes de sus estudiantes y busque apoyo de personas influyentes para los esfuerzos de sus estudiantes. Este tipo de acciones pueden ayudar a minimizar cualquier reacción en contra. Trabaje de cerca con sus estudiantes para asegurarse de que no tomen riesgos inapropiados y ayúdeles a seleccionar un nuevo tema si es apropiado. Considere la posibilidad de compilar una lista de recursos a donde sus estudiantes pueden acudir para recibir ayuda y soporte. 


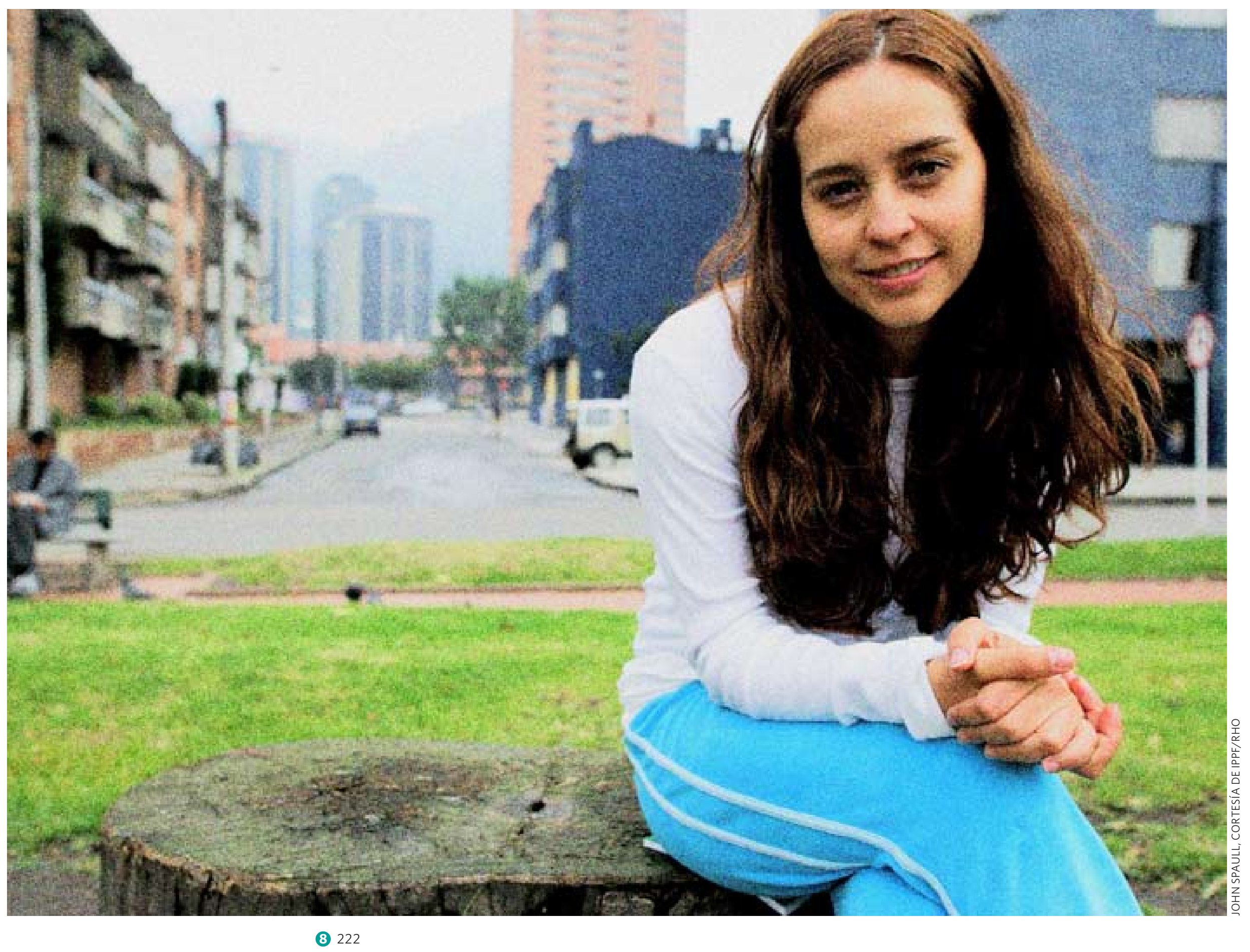




\section{ADVOCACY PARA LA SALUD SEXUAL Y REPRODUCTIVA, DERECHOS E IGUALDAD DE GÉNERO}

El material en esta unidad prepara a las y los estudiantes para:

Objetivos cognoscitivos

Nombrar al menos una forma en que las personas pueden hacer frente a la discriminación o injusticia en sus propias vidas.

Nombrar al menos una forma en que las personas pueden hacer frente a la discriminación o injusticia en sus comunidades.

Nombrar al menos una forma en que las personas pueden hacer frente a la discriminación o injusticia a nivel nacional o global.

\section{Objetivos afectivos}

Reflexionar en sus propios sesgos y prejuicios, así como en sus motivaciones para cambiar.

Sensibilizarse a situaciones caracterizadas por la injusticia, la discriminación y la marginación o desigualdad.

Reflexionar sobre sus experiencias y sentimientos al tratar de promover la salud sexual, los derechos humanos o la igualdad de género.

\section{Objetivos basados en destrezas}

Investigar sobre alguna preocupación que tengan acerca de la salud sexual, derechos humanos o desigualdad de género.

Desarrollar un plan de acción para emprender una actividad que contribuya a un mundo más justo. Implementar los pasos de este plan de acción. 


\section{reflexionar sobre nuestras propias actitudes}

1 Todos esperamos desarrollar nuestro pleno potencial como seres humanos. Sin embargo, nuestra capacidad para hacerlo puede verse afectada por normas sociales y estereotipos establecidos. Estas normas y estereotipos muchas veces se relacionan con el género, raza, edad, clase social, religión, identidad sexual y capacidades o discapacidades físicas de las personas.

2 En cierta medida, todo el mundo absorbe y transmite estereotipos ampliamente aceptados. El asimilar la discriminación (u opresión) significa que hemos llegado a creer que los estereotipos y normas son verdad, aún cuando nosotros seamos las víctimas de ellos. Algunas veces, las personas reconocen que ciertas normas y estereotipos son dañinos, pero dudan de poder cambiarlos.

3 Ustedes pueden hacer frente a los estereotipos relacionados con el género y otros aspectos de su propia vida. Para hacerlo, deben tener la capacidad y confianza para identificar cómo estos estereotipos han afectado su identidad, desarrollo personal y opciones. 
Ver el glosario al final de la unidad 1 para consultar definiciones de algunos términos usados en esta unidad.

\section{Todos nosotros podemos involucrarnos en la auto-reflexión y pensamiento crítico sobre nuestras propias opiniones, valores e ideas personales.}

Las siguientes son algunas preguntas difíciles pero importantes que cada uno de nosotros puede considerar al reflexionar acerca de los estándares de la comunidad y justicia en las áreas de género y sexualidad:

- ¿Qué adjetivos utilizaría yo para describir mis rasgos personales? ¿Son estas palabras usadas típicamente para describir a los niños y hombres o a las niñas y las mujeres?

- ¿Considero que ciertas emociones como la ira o la gentileza no son apropiadas para las niñas o los niños? ¿Cuáles serían algunos ejemplos?

- ¿Tengo tendencia a suponer que yo debería desarrollar (o no desarrollar) ciertas habilidades y talentos debido a mi sexo?

- ¿Tengo tendencia a suponer que, de manera natural, los niños y las niñas tienen diferentes capacidades intelectuales?

- ¿Tengo tendencia a escuchar más cuidadosamente las ideas de alguien si quien habla es niño o niña?

- ¿Pienso que las niñas no necesitan realmente practicar deportes tanto como los niños? ¿Por qué?

- ¿Considero que algunos comportamientos sexuales son aceptables para los niños pero no para las niñas, o viceversa?

- ¿Mantengo algunos estereotipos acerca de la sexualidad de las personas de otros grupos étnicos o raciales?

- ¿Qué pienso acerca de una persona que se identifica con un género diferente al que se le asignó al nacer?

- ¿Cómo me siento respecto a que las niñas tengan más tareas en el hogar que los niños?

- ¿Qué tan aceptable es para un hombre el recibir más paga que una mujer por el mismo trabajo?

- Como persona adulta ¿votaría yo por una mujer para presidente? ¿Por qué sí? ¿Por qué no?

- ¿Contrataría a un hombre para que se hiciera cargo de niños pequeños? ¿Por qué sí? ¿Por qué no?

- ¿Cómo me siento acerca de burlarme de alguien que es homosexual si la burla no es extrema? ¿Por qué me siento así?

- ¿Pienso que, algunas veces, las niñas y mujeres deben ser culpadas cuando son víctimas de violación? De ser así, ¿bajo qué circunstancias?

- ¿Sobre qué bases desarrollé esas opiniones? ¿Dónde aprendí a formar esas actitudes? 
5 Podemos también preguntarnos acerca de la justicia y estándares comunitarios relacionados con el VIH y el SIDA. Tales preguntas pueden ser difíciles pero son importantes.

Por ejemplo:

- ¿Aplico estereotipos a las personas que viven con el VIH o el SIDA? ¿Dónde aprendí esas actitudes?

- ¿Cómo me sentiría si me enterara que mi hermana o hermano hubiera contraído la infección con VIH?

- ¿Cómo veo a las personas que pagan por tener relaciones sexuales y cómo a las que les venden favores sexuales? ¿Pienso acerca de ellos de manera similar o diferente y sobre qué bases he formado mis actitudes?

- ¿Qué responsabilidad, si es que la hay, tengo de defender la dignidad y derechos de las personas VIH-positivas?

- ¿Tengo alguna responsabilidad de hacerme una prueba de VIH?

- Si contraigo el VIH, ¿tengo responsabilidad de informarlo a mis parejas sexuales, aún si estamos usando condones?

6 Todos los días tomamos decisiones sobre la forma en que reaccionamos ante otras personas y como las tratamos. Muchas veces, tomamos decisiones sin detenernos a pensar acerca de lo que es justo o ético, o sobre otras decisiones que podríamos tomar. Actuar con justicia significa tratar a las personas con igual respeto como un asunto de ética personal y derechos humanos. 


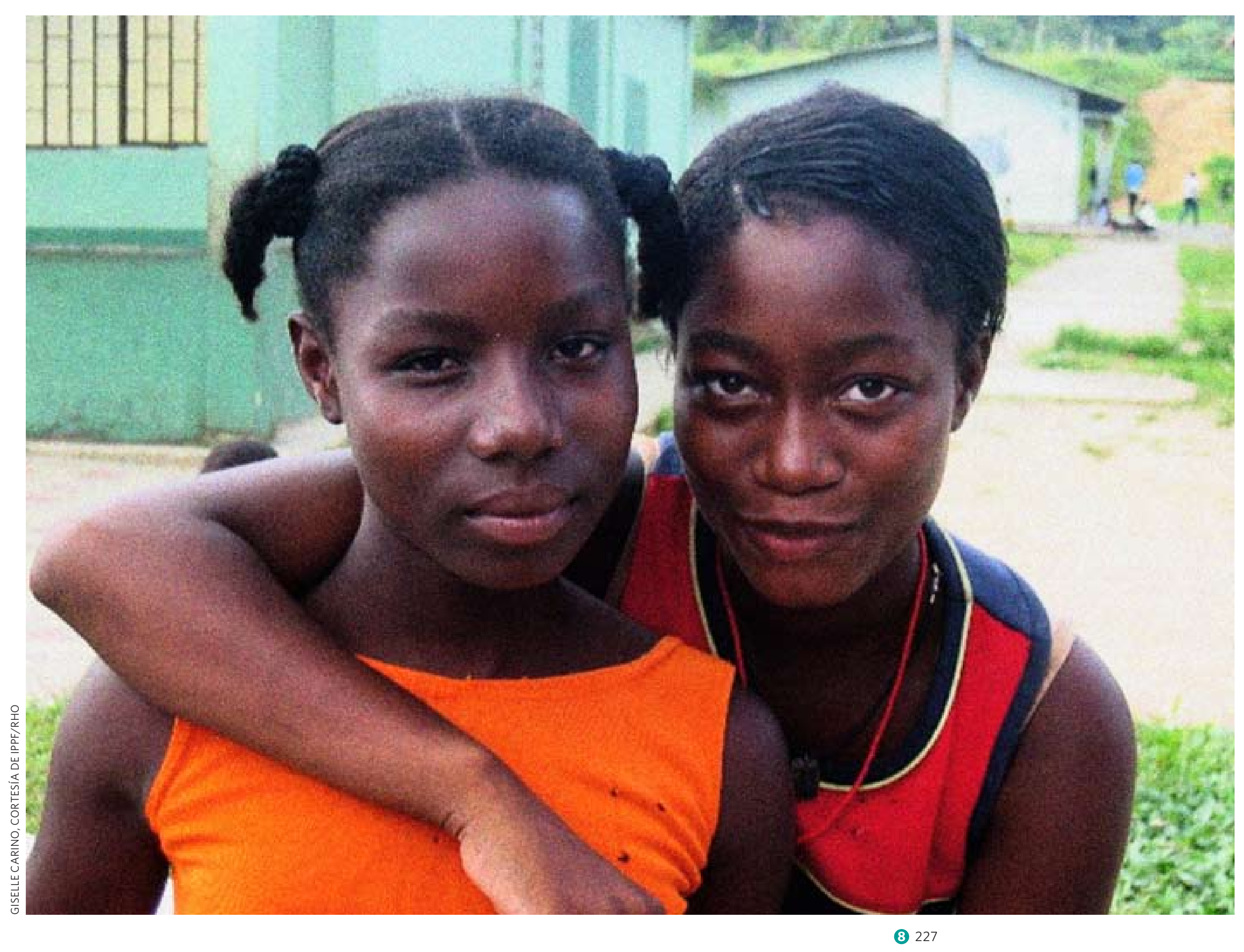




\section{reconocer si algo es justo o injusto}

1 Para poder hacer frente a la discriminación, las personas primero tienen que poder reconocerla tanto dentro de sí mismas como en el mundo que les rodea.

2 Reconocer la discriminación no es siempre fácil. En algunos casos, puede ser obvia (por ejemplo, en un comentario altamente despectivo o en casos de violencia doméstica). En otros casos, puede ser más sutil y difícil de notar (por ejemplo, ignorando la opinión de alguien debido a su sexo).

3 Una pregunta que las personas pueden plantearse a sí mismas cuando sientan que están respondiendo con base en estereotipos o prejuicios es “¿Por qué tengo esta opinión?" Dar una respuesta honesta a esta pregunta puede provocar una útil reflexión y ayudar a una persona a reconocer cuando la discriminación puede estar en la raíz de su comportamiento. 


\section{cambiar el mundo que nos rodea}

1 Todos sentimos alguna presión cultural para adaptarnos a "como están las cosas".

- Algunas personas aceptan las cosas como son, aún cuando sean injustas. Puede no importarles. Pueden no saber cómo cambiar la situación. O pueden sentir que tratar de hacer un cambio podría ser incómodo o riesgoso.

- Otras personas se manifiestan en contra de condiciones injustas en sus propias relaciones y familias, en sus escuelas, en sus comunidades y en su sociedad. Algunas personas se manifiestan o actúan aún cuando sus acciones podrían ponerlas en riesgo emocional, económico, legal, social o físico.

2 Las personas que creen en la igualdad social pueden tomar varias medidas. Rara vez es efectivo desafiar a todo el tejido social. En vez de ello, las personas pueden contribuir para lograr cambios pequeños pero importantes, incluso en entornos altamente conservadores.

3 Hacer una diferencia puede ser una experiencia estimulante y empoderadora; y puede construir nuevas relaciones con otras personas.

Por ejemplo, toda la gente puede:

- expresar actitudes, valores y opiniones que son consistentes con sus creencias;

- respetar los derechos humanos de toda las personas;

- actuar en contra de la discriminación; y

- ayudar todos los días, a través de pasos pequeños y grandes, a cambiar vidas. 
4 Las personas pueden hacer frente a las injusticias (incluida la desigualdad de género) que ven en sus propias relaciones y vidas.

Por ejemplo:

- Todos nosotros podemos dejar de usar lenguaje degradante o hacer bromas degradantes sobre personas que son diferentes a nosotros. También podemos protestar cuando otras personas lo hacen. Las personas pueden hacerse más conscientes de las actitudes carentes de respeto o degradantes que se presentan en los medios (letra de las canciones, videos, programas de televisión, revistas de historietas y así sucesivamente).

- Una niña puede decidir hacer un esfuerzo serio para convencer a sus padres que no la casen a una edad temprana. Su hermano puede ayudar y él puede rehusarse a recibir una dote cuando esté a punto de casarse.

- Un hombre puede pedir a sus padres que dejen de acosar a su esposa (la nuera de ellos) y a su familia para obtener una dote mayor.

- Una persona puede alentar a uno de sus padres que esté en posición de dar empleo, para que contrate a trabajadores VIH-positivos.

- Un adolescente puede presionar a sus amigos cuando se burlen o intimiden a alguien, para que dejen de hacerlo.

- Las personas pueden aceptar abiertamente a miembros de su familia cuya sexualidad esté fuera de la norma social.

- Toda persona puede volverse más sensible a los sentimientos de personas que tienen otras formaciones y situaciones. El tener apertura de mente y capacidad de escuchar son rasgos esenciales para desarrollar relaciones respetuosas.

\section{Las personas pueden también decidir ayudar a poner fin a la injusticia que observan en} sus comunidades y su sociedad.

Por ejemplo, ellas pueden:

- apoyar a una persona que esté siendo marginada injustamente; y

- educar a las personas de una en una y elevar su nivel de conciencia respecto a las injusticias locales. 
6 Las personas pueden unirse a esfuerzos locales para lograr un trato justo e igualdad en relación con el género y la sexualidad.

Por ejemplo, ellas pueden:

- ayudar a asegurar que las personas que viven con el VIH y SIDA sean tratadas de manera justa en la comunidad;

- convencer a las personas en la comunidad que dejen de circuncidar a sus hijas;

- establecer grupos de vigilancia vecinales para intervenir en casos de violencia doméstica;

- crear lugares seguros a donde puedan acudir por ayuda las víctimas de violencia doméstica; y

- trabajar para establecer la educación sexual y de género en las escuelas.

\section{Las personas pueden unirse a campañas nacionales para lograr la justicia e igualdad.}

Tales campañas pueden incluir a quienes:

- ayudan a las niñas a permanecer en la escuela;

- salvan la vida de niñas y mujeres mediante la despenalización del aborto;

- reforman leyes que castigan a las personas con base en su identidad sexual;

- hacen labor de advocacy a favor de un mayor gasto del gobierno para prevenir y tratar problemas de salud materna (como la fístula obstétrica);

- hacen labor de advocacy para la aplicación de leyes que hacen que el abuso conyugal y la violación marital se consideren como crímenes; y

- aseguran la aplicación de leyes que protegen la igualdad de género (incluso frente a la oposición de movimientos conservadores o religiosos).

8 Las personas pueden apoyar o unirse a movimientos para el cambio social a nivel global.

Por ejemplo:

- la campaña de Listón Blanco (un movimiento de hombres y niños en todo el mundo para terminar la violencia contra las mujeres);

- campañas de arte y cultura (como la de Dance4Life) para elevar la conciencia sobre el VIH y SIDA;

- movimientos para terminar con la trata de mujeres y niñas [ver hoja informativa sobre Trata de Seres Humanos con

Fines de Explotación Sexual]; y

- redes dirigidas por jóvenes para promover los derechos y servicios sexuales y reproductivos. 


\section{Algunas de las actividades que las personas emprenden para provocar el cambio}

social incluyen:

- La investigación;

- Educar a otras personas, tanto individualmente como en grupos;

- Educar a tomadores de decisiones;

- Contactar y educar a periodistas;

- Escribir y firmar peticiones y cartas;

- Trabajar en campañas electorales;

- Cabildear con funcionarios electos para lograr mejores leyes y su aplicación;

- Defender en los tribunales los derechos de las personas que han sido discriminadas o víctimas de abuso;

- Participar en marchas y mítines;

- Escribir proclamas y declaraciones de posición;

- Asistir a demostraciones de protesta y huelgas;

- Manifestaciones y boicoteo;

- Creación y representación de obras de teatro y musicales para concientizar;

- Establecimiento de servicios directos para mostrar lo que puede hacerse; y

- Organización de talleres de capacitación para enseñar a prestadores de servicios sanitarios, policías y otras personas dedicadas al servicio público sobre cómo abordar mejor algún tema en particular. 


\section{obstáculos enfrentados en el trabajo de advocacy para el cambio social}

1 Trabajar por la justicia puede ser difícil y peligroso. Con frecuencia implica cuestionar a la opinión pública o a personas e instituciones que tienen autoridad y poder. En algunos casos, puede conllevar estigma, encarcelamiento o daño físico.

2 Debido a estos riesgos, no siempre es posible cuestionar o protestar directamente contra algún caso de discriminación.

3 Si no es posible cuestionar o desafiar algún caso específico de discriminación, una persona puede buscar una forma más segura de responder. Sin embargo, es importante recordar que lo que es seguro en un entorno no siempre es seguro en otro.

Algunas de las formas en que las personas (incluida la gente joven) han respondido a la discriminación, incluyen:

- encontrar una forma de disminuir su efecto en sí mismas o en otras personas;

- hablar sobre la discriminación con una persona confiable y experimentada;

- establecer una página web o blog; y

- encontrar unas cuantas personas solidarias y acudir a hablar con alguna autoridad. 


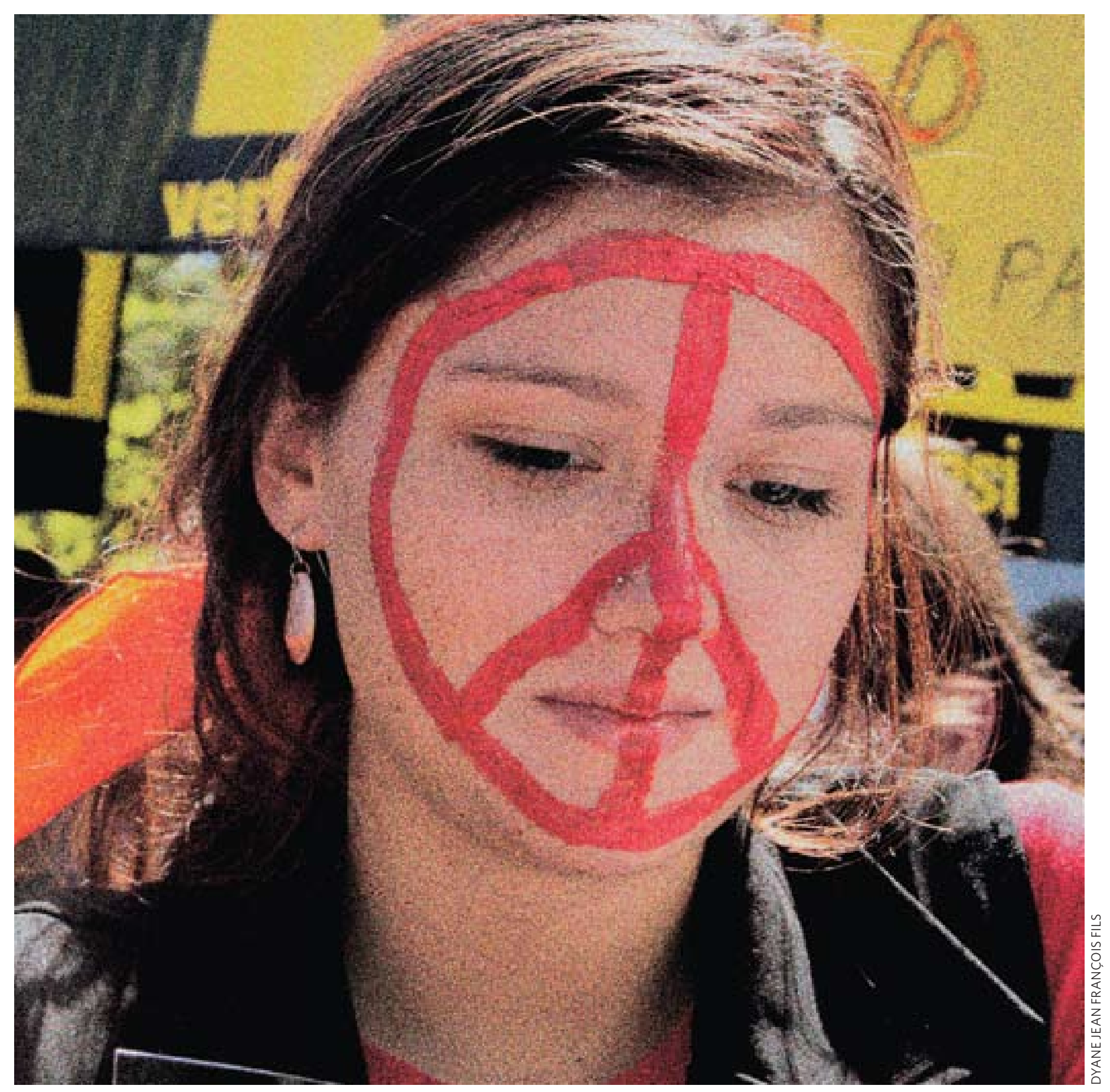




\section{el significado y poder de la advocacy en la vida de las personas}

1 Usualmente, las personas son más efectivas en la creación del cambio social si éste se relaciona con algún tema que conocen y que les es importante; $y$, muchas veces, porque les afecta directamente.

2 Las personas pueden aprender habilidades para cambiar el mundo que les rodea. Estas habilidades pueden usarse en muchas situaciones diferentes.

3 Ya sea que trabajemos por la justicia en nuestras decisiones personales cotidianas o en campañas sociales organizadas, promover la justicia y los derechos humanos puede dar significado a la vida de una persona y puede ser personalmente empoderadora.

VER EL LIBRO DE ACTIVIDADES Actividad 53

iinspírensel creación del cambio

Las y los estudiantes seleccionan una cita que les inspire y exploran qué significaría aplicar el mensaje de la cita en sus propias vidas. 


\section{tomar acción: módulo de aprendizaje basado en proyectos}

Las personas pueden aprender habilidades para cambiar el mundo que les rodea, incluso en las formas más pequeñas y en los entornos más conservadores. Estas habilidades pueden usarse en muchas situaciones.

Las personas jóvenes pueden ser vigorosas y efectivas activistas para el cambio.

Los siguientes pasos son importantes para crear el cambio social.

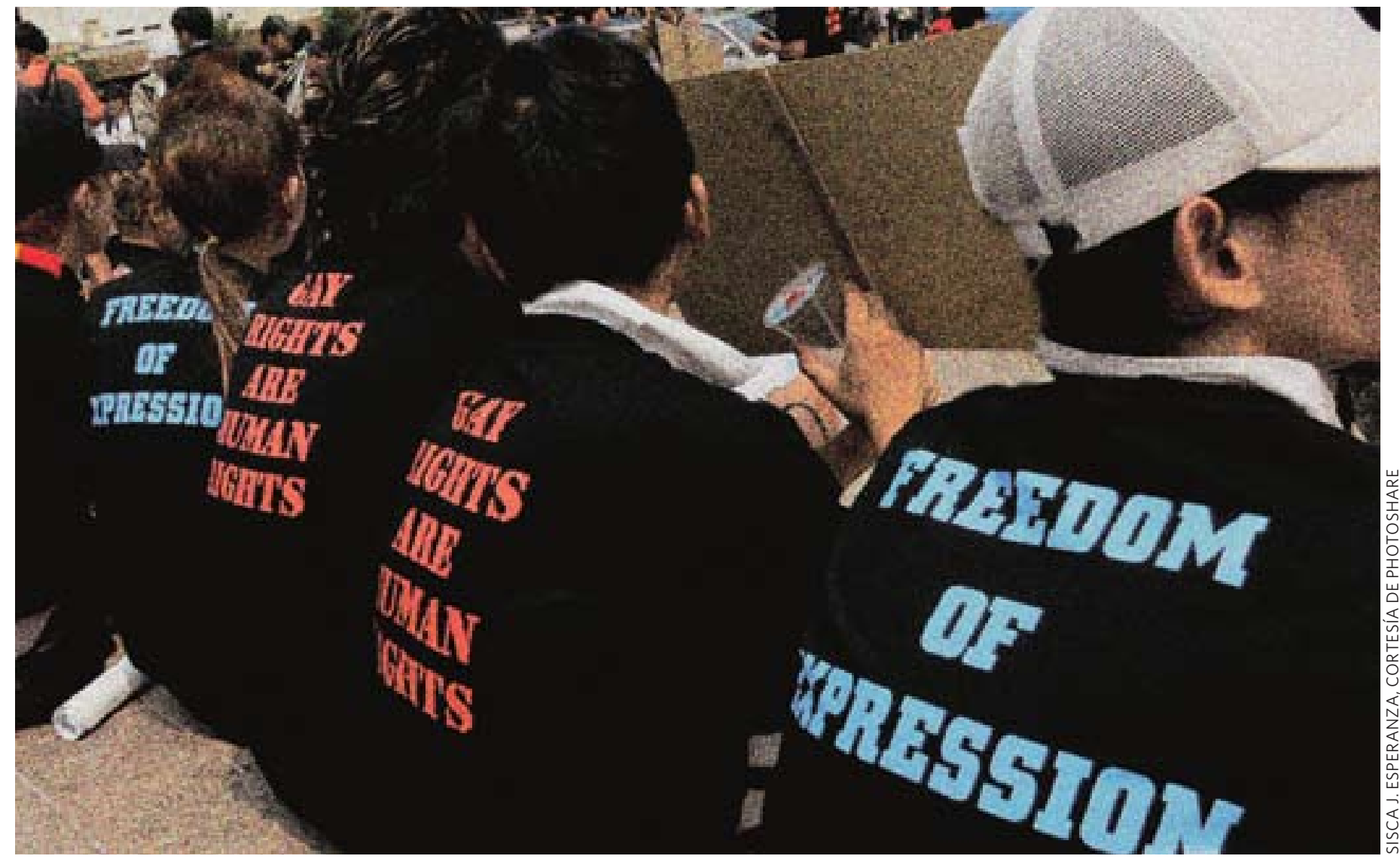

8236 
Paso 1: Identifique un tema o problema que le interese. Piense sobre por qué usted se interesa por este problema. Esto puede ser un problema que le afecte a usted solamente o a otra persona. Puede afectar a unas cuantas personas, por ejemplo, en su familia o salón de clase. Puede ser un problema que involucre a todos o algunos de los miembros de su comunidad, o incluso un problema a gran escala que afecte a muchas personas en un país o en el mundo.

Paso 2: Obtenga y analice la información sobre el problema y quiénes han tomado pasos para abordarlo.

Por ejemplo:

- Obtenga información sobre quiénes están ya involucrados en abordar este problema a nivel local o nacional. Identifique cómo vincularse con tales esfuerzos.

- Hable con otras personas sobre cómo perciben ellas el problema.

- Cuando sea posible, aprenda más mediante la lectura sobre el problema.

- Identifique las raíces subyacentes al problema.

- Examine qué instituciones, políticas, leyes, reglas, normas culturales y asignaciones de recursos permiten que el problema persista. (Ustedes pueden elaborar un tipo de "mapa político" con esta información).

Paso 3: Decida qué cambios quiere conseguir. Piense sobre las metas a corto plazo y las metas a largo plazo. Sea imaginativo, pero también realista.

Los cambios podrían incluir:

- cambiar sus propias actitudes o comportamiento;

- aumentar el conocimiento y conciencia en las personas que le rodean;

- alentar a las personas para que cambien su comportamiento y sean más responsables en cuanto al respeto de los derechos de otras personas;

- cambiar las reglas dentro de una institución comunitaria; y

- hacer arreglos para que ciertas personas obtengan acceso a un programa o reciban los servicios que necesitan.

\section{VER EL LIBRO DE ACTIVIDADES} Actividad 54

\section{un tema que me interesa}

Las y los estudiantes identifican un tema o problema en la sociedad que les interese. 
Paso 4: Piense acerca de quién podría ayudarle a tomar las medidas necesarias hacia el cambio que desea ver - ya sea mediante el ofrecimiento de asesoría o ayudándole de manera más directa. Por ejemplo, ustedes podrían acercarse a un padre de familia, director de escuela, líder comunitario o funcionario electo.

- Al hablar con otras personas, usted puede motivarlas para que sean más solidarias o participativas. Usted puede beneficiarse de sus habilidades y asesoría; y tomen en cuenta que ustedes no necesitan hacer todo por sí mismos.

- Preste atención a las diferentes perspectivas de las personas.

Paso 5: Únase a alguna organización o encuentre colaboradores. iHay poder en los números!

- Los esfuerzos colectivos - incluidas las voces de las personas que muchas veces pasan sin ser escuchadas - con frecuencia reciben más atención y son más efectivas que los esfuerzos individuales.

- Típicamente, una persona puede trabajar más fácilmente en pro de cualquier cambio — incluso uno pequeño — si ella o él cuenta con la cooperación y apoyo moral de otras personas.

Paso 6: Identifique a su audiencia principal (a la que dirige el mensaje). Aclare lo mejor que pueda el mensaje que quiere presentar acerca de los cambios que desea ver.

Paso 7: Conduzca una tormenta de ideas acerca de las acciones posibles que podrían hacer que los cambios sucedan. Tenga en mente la forma más apropiada de llegar a la audiencia a la que dirige el mensaje.

Por ejemplo, considere:

- reunirse con el director de la escuela o un líder comunitario;

- escribir un artículo para el diario escolar;

- organizar un concierto o baile para recaudar dinero para el cambio;

- conducir sesiones educativas a la comunidad o en su salón de clase; e

- involucrarse u organizar la participación política a nivel local. Por ejemplo, usted puede producir y distribuir folletos, crear y representar una obra de teatro callejero, o trabajar como voluntario para una campaña política que comparta sus preocupaciones y valores. 
Paso 8: Converse, estudie y compare todas las acciones posibles. Elija entonces aquellas que parezcan las más viables y efectivas. Desarrolle su plan de acción.

[Ver Unidad 5, páginas 151-153.]

Paso 9: Considere las barreras que puede enfrentar al emprender estas acciones en su comunidad.

Por ejemplo:

- Usted puede ser ignorado.

- Usted puede no ser capaz de obtener todos los recursos que necesite.

- Usted puede no tener suficientes aliados.

Paso 10: Asegúrese de que sus acciones no causen daño a usted mismo o a otras personas. Asegúrese de preguntar a un adulto confiable y a otros líderes jóvenes sobre los riesgos que pudiera no haber considerado.

Algunos riesgos potenciales incluyen:

- Estigma social o disciplina, en el hogar, en la escuela, o en la comunidad.

- Hostilidad o incluso daño físico de parte de alguien que se oponga a sus acciones.

- Consecuencias financieras o legales.

Paso 11: Revise su plan, si es necesario para asegurarse de que ningún daño se derivará de él. 
Paso 12: Identifique a su oposición. Estudie sus argumentos y actividades. Prepare argumentos en contra que sean precisos y honestos.

Paso 13: Finalice su plan de acción.

Paso 14: Identifique y obtenga los recursos humanos y materiales que necesitará para implementar su plan.

Algunos ejemplos de recursos humanos son:

- personas que pueden ayudar a entrar en contacto con el gobierno local;

- personas que saben cómo redactar un comunicado de prensa;

- personas que pueden ayudar a iniciar un sitio web; y

- personas que pueden realizar otras tareas involucradas en la comunicación de su mensaje.

Algunos ejemplos de recursos materiales son:

- dinero o donaciones de alimentos para servir o vender;

- equipo o suministros necesarios, los cuales pueden ser prestados; y

- apoyo con los viajes.

Paso 15: Ejecute su plan de acción. 


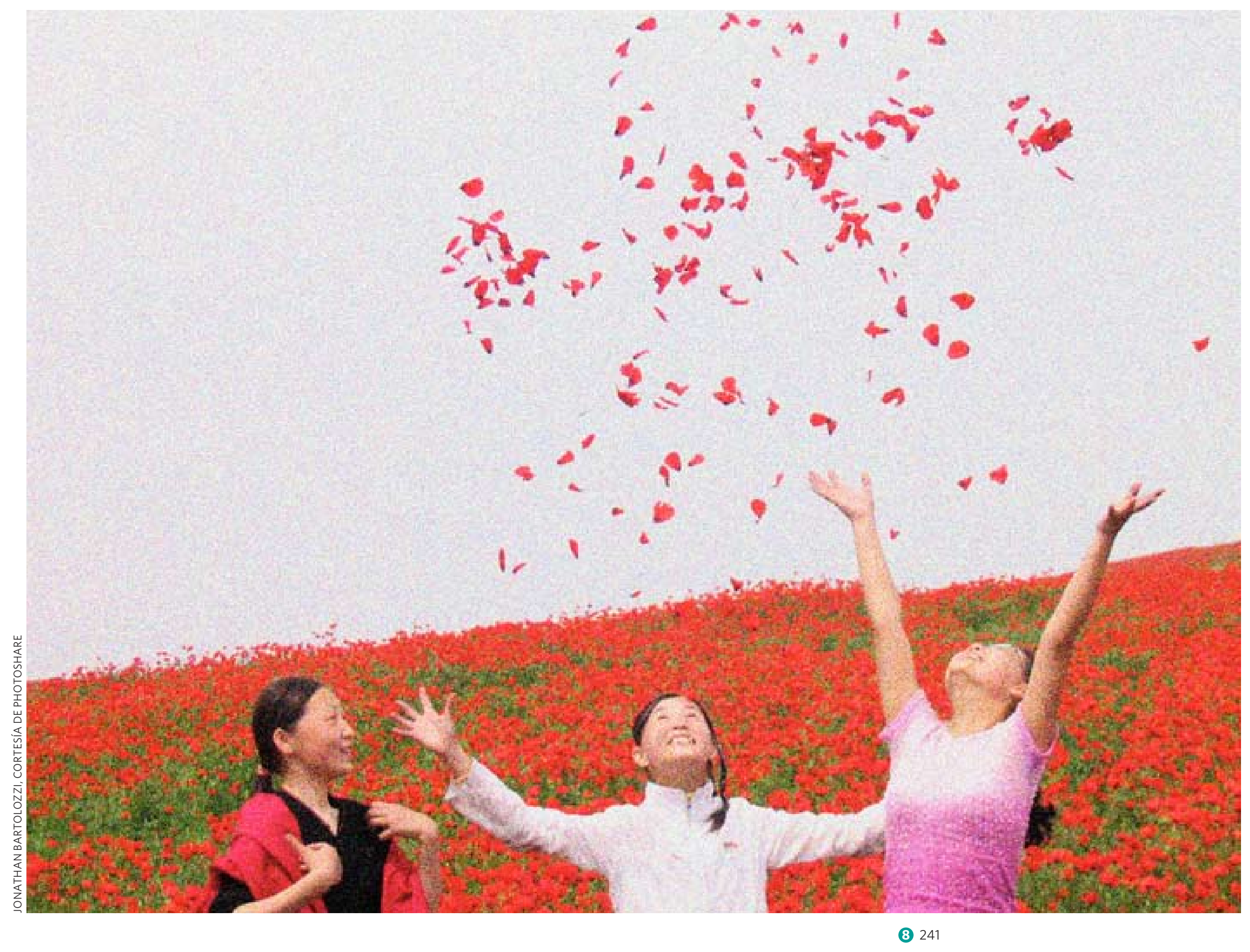


Paso 16: Evalúe la efectividad de su trabajo en términos de sus metas a corto y largo plazos. Haga ajustes. Busque asesoría y apoyo de otras personas si es necesario.

Paso 17: Continúe trabajando en el problema. El cambio social usualmente es una meta a largo plazo.

El cambio es posible. Usted puede siempre encontrar algo que puede hacer, sin importar lo pequeño de la acción. No se desaliente si los problemas parecen ser grandes y abrumadores.

Finalmente, tenga en mente que mientras trata de cambiar el mundo a su alrededor, usted debe ser equitativo, respetuoso y justo en sus acciones e interacciones cotidianas. 
"Sé tú mismo el cambio que quieres ver en el mundo".

“No se requiere que termines el trabajo. Pero tampoco eres libre de abandonarlo".

- Adaptado de Rabí Tarfon, Mishnah, Avot

“Tienes que tener un sueño; si no tienes un sueño ¿cómo esperas hacerlo realidad?"

— Oscar Hammerstein, "Happy Talk” 


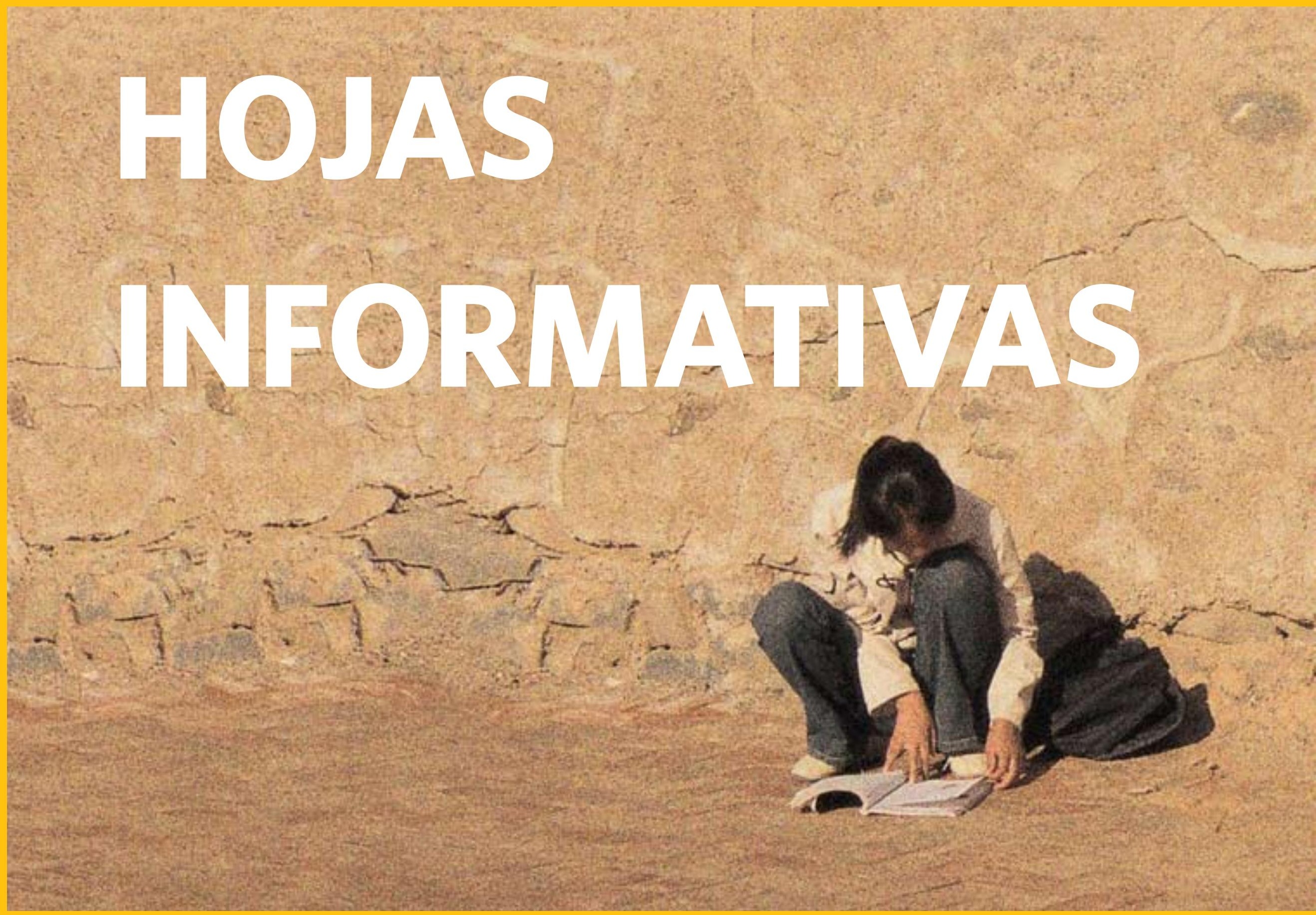




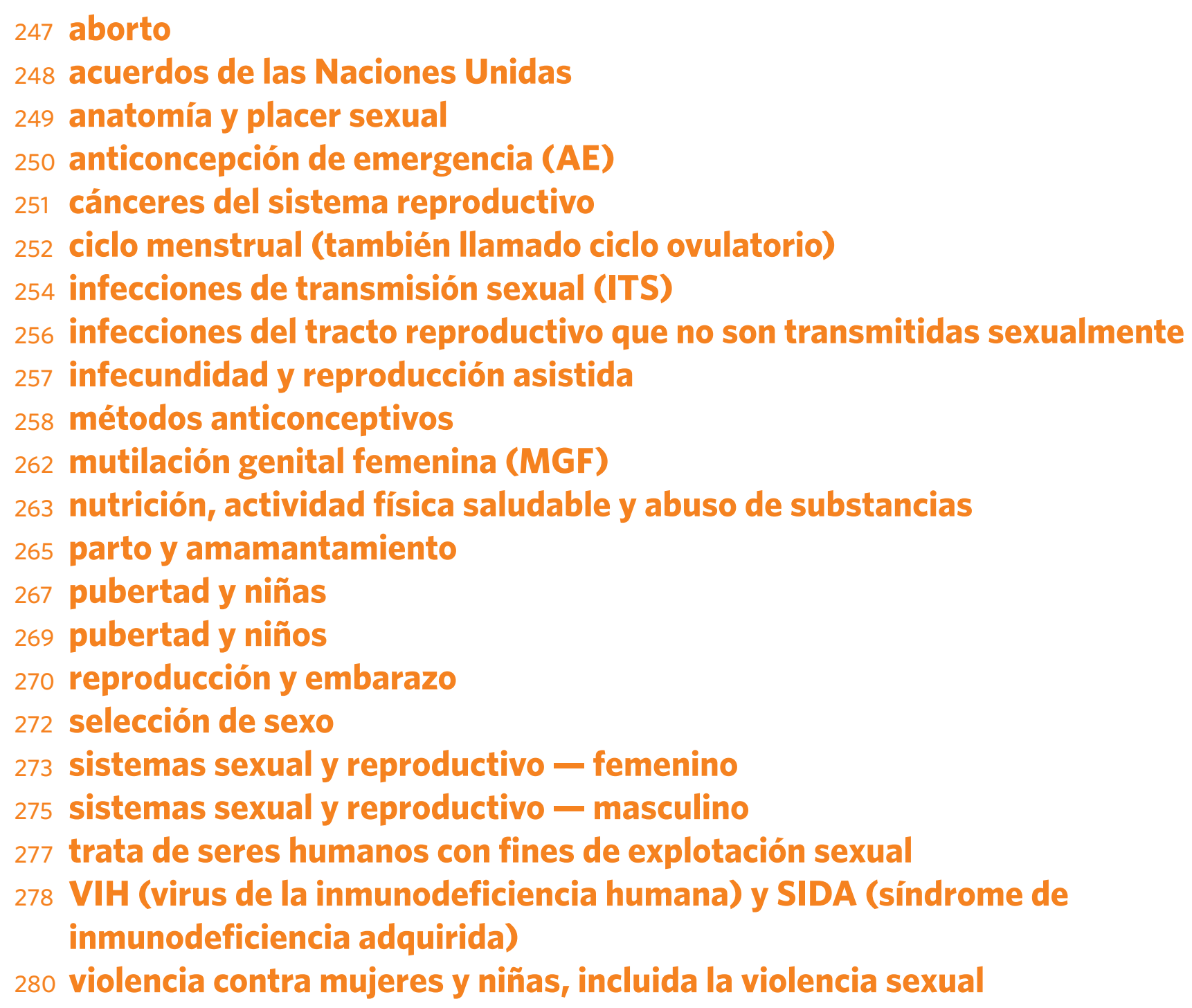




\section{¿Qué es el aborto?}

Un aborto es la terminación de un embarazo antes de que el feto sea viable. Un aborto que ocurre por sí solo se llama aborto espontáneo. $\mathrm{O}$ bien, un aborto puede ser inducido o esto es, una mujer busca terminar con un embarazo. Hay muchas razones diferentes por las que la gente decide buscar un aborto. Estas razones pueden ser personales y/o relacionadas con el estado de salud.

\section{¿Qué tan común es un aborto?}

El aborto es muy común. Cerca de uno de cada cinco embarazos termina en aborto espontáneo (con frecuencia antes de que la mujer esté consciente de que está embarazada). Un número similar de embarazos - cerca de uno de cada cinco - termina con un aborto inducido. La mayoría de los abortos — ya sean espontáneos o inducido — tienen lugar cuando el embarazo tiene ocho semanas o menos.

\section{¿Qué implica un aborto inducido?}

Hay dos métodos principales de aborto inducido. Uno es un procedimiento quirúrgico breve durante el cual un prestador de servicios utiliza instrumentos médicos. Los instrumentos son utilizados para succionar o remover el contenido del útero (el recubrimiento rico en sangre que sustenta al embrión o, en abortos tardíos, el feto; este recubrimiento es expulsado durante el período menstrual si la mujer no está embarazada). El segundo método implica la ingestión de una o más píldoras que causan cólicos y el inicio del sangrado menstrual. Con este método, la mujer expulsa el recubrimiento de su útero $y$, con él, el embrión. Ocasionalmente, parte del recubrimiento permanece dentro del útero. En tales casos, el prestador de servicios de salud utiliza instrumentos médicos para completar el procedimiento (como se describe anteriormente). Ambos métodos son muy efectivos si se realizan bajo las condiciones médicas apropiadas.

\section{¿Es seguro el aborto?}

Cuando se realiza bajo condiciones apropiadas, un aborto es un procedimiento simple y seguro. El procedimiento debe ser conducido por una o un prestador de servicios de salud capacitado, utilizando el equipo y técnica apropiados y conforme a estándares sanitarios. El aborto más seguro es el que se practica al principio del embarazo. Cuando se realiza durante la primera mitad del embarazo (como virtualmente ocurre con todos los abortos) es mucho más seguro que tener un bebé.

En muchos lugares, sin embargo, el aborto es realizado por personas que carecen de las habilidades necesarias. Con frecuencia, se realizan en un ambiente que no cumple con estándares médicos mínimos. En estas situaciones, el aborto conlleva un gran riesgo. A nivel mundial, cerca de la mitad de los abortos son inseguros; y casi todos ellos (95 por ciento) ocurren en los países en desarrollo. Con frecuencia, el más alto riesgo se tiene en las áreas rurales. Como resultado de esto, cerca de 70,000 mujeres y niñas mueren cada año por complicaciones de abortos inseguros. Estas muertes pueden evitarse.

\section{¿Es legal el aborto?}

En la mayoría de los países, el aborto inducido es legal bajo algunas o bajo cualquier circunstancia. Cuando el aborto se permite legalmente, tiende a ser más seguro. Cuando se penaliza el aborto, los procedimientos inseguros son comunes y las mujeres y niñas sufren complicaciones de salud.

Penalizar el aborto no lo hace menos común. De hecho, algunos de los países en donde el aborto está más restringido, tienen de las tasas más altas de aborto.

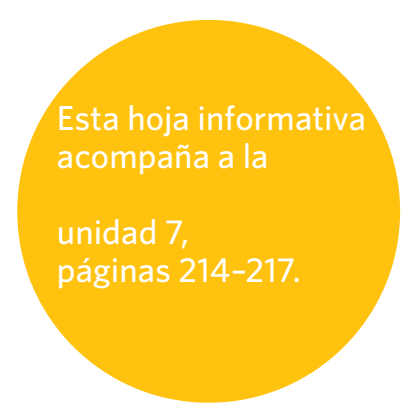


¿De qué forma las Naciones Unidas establecen los tratados y acuerdos?

Primero, la Organización de las Naciones Unidas (ONU) convoca a una conferencia global. El siguiente paso es una reunión de planificación que involucra a representantes de alto nivel de diferentes países, expertos técnicos y a representantes de organizaciones no gubernamentales (ONG). Todas estas personas negocian el contenido de un documento que se presenta por escrito. Las ONG no tienen un rol oficial o voto, pero frecuentemente tienen una activa participación en dar forma al contenido de esos documentos. Entonces la ONU realiza la conferencia oficial, en la cual los representantes de los países miembros finalizan y aprueban los documentos negociados. Estos documentos pueden tener la forma de tratados (que son legalmente vinculantes u obligatorios), o declaraciones no obligatorias o programas y plataformas para la acción. En cualquier caso, los países pueden elegir firmar e documento, comprometiéndose a cumplirlo e implementarlo. Cuando un país ratifica un tratado, éste se vuelve legalmente obligatorio para ese país.

\section{¿De qué forma hacen la diferencia los tratados y acuerdos} de las Naciones Unidas?

Los países emiten informes periódicos sobre cómo están (o no están) cumpliendo con un tratado de derechos humanos. Con frecuencia, las violaciones a los tratados de derechos humanos pueden ser atendidas por las cortes internacionales $\mathrm{o}$, en algunos casos, por organismos de las Naciones Unidas u organismos regionales de derechos humanos. Muchas ONG usan los acuerdos internacionales como base para incidir a favor de mejores leyes, políticas y programas en sus países. También pueden hacerse cargo de monitorear su cumplimiento por parte del gobierno. Los acuerdos de ayuda internacional o de comercio algunas veces están ligados al respeto que un país tiene de ciertas convenciones de derechos humanos.

\section{¿Cuáles son algunos de los documentos oficiales de} derechos humanos más importantes?

La Declaración Universal de los Derechos Humanos, adoptada por la Asamblea General de la ONU en 1948, reconoce el principio de que "todos los seres humanos nacen libres e iguales en dignidad y derechos"; y establece los derechos humanos que están garantizados para todas las personas. Incluye derechos relacionados con la vida y la seguridad; la libertad personal; la libertad económica, social y cultural; la educación; y el trabajo, entre otros. Junto con el Pacto Internacional sobre Derechos Económicos, Sociales y Culturales y el Pacto Internacional sobre Derechos Civiles y Políticos, constituye la Carta Internacional de los Derechos Humanos.

\section{La Convención de las Naciones Unidas sobre los Derechos} del Niño (CRC) en inglés, adoptada en 1989, pretende proteger los derechos individuales de las niñas y niños-incluidos los derechos a la protección de la violencia, al más alto estándar posible de salud y a la educación, entre otros. La CRC establece los derechos y las responsabilidades de las familias y gobiernos para se cumpla con estas garantías.

\section{La Convención sobre la Eliminación de Todas las Formas de} Discriminación en Contra de las Mujeres (CEDAW en inglés), adoptada en 1979, reconoce los derechos de las mujeres y establece una agenda para terminar con la discriminación contra las mujeres en cada sector de la sociedad. Los derechos abordados incluyen la participación política, salud, educación, empleo, matrimonio, familia e igualdad ante la ley. La Cuarta Conferencia Mundial sobre la Mujer (FWCW en inglés),

realizada en Beijing en 1995, reenfocó los esfuerzos para lograr la igualdad de las mujeres y adoptó una Plataforma para la Acción. Los temas incluyeron el empoderamiento de las mujeres, la pobreza, la situación de las niñas y la violencia contra las mujeres.

\section{The Conferencia Internacional sobre Población y Desarrollo}

(ICPD), realizada en el Cairo en 1994, adoptó el Programa de

Acción que establece prioridades para abordar temas de población y desarrollo, entre los que destacan la salud sexual y reproductiva, la educación, los derechos humanos, el medio ambiente, la migración y el VIH y SIDA. Las metas de la CIPD incluyen el acceso universal a los servicios de atención y educación en salud reproductiva, especialmente para las niñas, así como la reducción de la mortalidad de infantes, niños y madres. Este documento ha sido una herramienta importante para activistas y gobiernos que buscan proteger los derechos reproductivos. 
No hay dos personas que tengan la misma respuesta sexual. Con frecuencia esa respuesta se ve afectada por experiencias pasadas, actitudes culturales y sentimientos respecto a una pareja sexual y a una situación sexual específica. La edad; el estado físico (como la enfermedad o la fatiga); el uso del alcohol, drogas o medicamentos; y el estado emocional (incluida la sensación de comodidad o de ansiedad) pueden también afectar la respuesta sexual. Estos factores son ejemplos de por qué algunas veces se dice que el cerebro puede ser el órgano más importante en la excitación sexual.

\section{¿Qué sucede durante la excitación sexual?}

La excitación sexual se refiere a la respuesta del cuerpo al deseo, anticipación y participación en la relación sexual. Comienza con la estimulación sexual, por ejemplo, con una caricia, un olor, una visión, un sabor, un sonido, un pensamiento, o una fantasía que tenga significado erótico para una persona. Con frecuencia, los hombres se excitan especialmente si se les toca o acaricia el pene o escroto. En las mujeres, el órgano más sensible es el clítoris. El clítoris es rico en terminaciones nerviosas y su única función es el placer sexual. Tanto el pene como el clítoris se llenan de sangre y se ponen en erección en respuesta a la excitación; esta congestión aumenta su tamaño y sensibilidad.

La excitación sexual también implica la respuesta de otros órganos. El latido del corazón aumenta, los músculos se tensan, la presión sanguínea sube, la piel puede ruborizarse y los pezones se pueden poner en erección. En las mujeres, la vagina puede humedecerse y expandirse. En los hombres, el escroto se retrae hacia el cuerpo, una glándula libera un fluido que limpia la uretra y la vejiga se cierra para que la orina y el semen no se puedan mezclar. Durante una experiencia sexual, el nivel de excitación puede aumentar o disminuir alternativamente. La excitación puede durar solamente unos cuantos minutos o varias horas.

Si la estimulación sexual continúa, la excitación puede intensificarse y conducir al orgasmo. Justo antes del orgasmo, la respiración, la presión sanguínea y el ritmo cardiaco aumentan. Con frecuencia, el excitarse y llegar al orgasmo toma más tiempo en las mujeres que en los hombres.
Aunque algunas mujeres perciben áreas sensibles en la vagina (algunas veces llamado el "punto G"), la mayoría de las mujeres alcanzan el orgasmo a través de la estimulación directa del clítoris, más que a través del coito.

\section{¿Qué ocurre durante un orgasmo?}

El orgasmo es el clímax del placer sexual. Es acompañado por una serie de contracciones rítmicas en el área pélvica; espasmos musculares y sensaciones de placer en todo el cuerpo; y una liberación repentina de la tensión sexual. Con el orgasmo, el cuerpo también libera sustancias químicas llamadas endorfinas, las que producen sentimientos agradables. La experiencia del orgasmo varía enormemente en las personas y de un orgasmo a otro en la misma persona. Algunas mujeres pueden tener más de un orgasmo en un período de tiempo relativamente corto; de hecho, pueden experimentar un deseo incontenible de hacerlo. Después del orgasmo, la vagina se vuelve más lubricada con las secreciones de fluidos.

En los hombres, el orgasmo usualmente, pero no siempre, es acompañado por una eyaculación. Durante una eyaculación, la próstata, las vesículas seminales y los vasos deferentes se contraen, liberando sus fluidos que se mezclan con el esperma proveniente del epidídimo para formar el semen. En este punto, los hombres sienten que la eyaculación es imparable. Entonces, los músculos pélvicos se contraen, empujando el semen fuera del pene a través de la uretra. Después de la eyaculación, los hombres no pueden lograr tener otra erección por un período de tiempo, que varía desde varios minutos hasta 24 horas. La longitud de este período aumenta con la edad.

\section{¿Qué sucede si usted se excita sexualmente pero no tiene}

\section{un orgasmo?}

Después de un momento los órganos genitales se descongestionan (vuelven a su volumen y coloración normal). La presión sanguínea y el ritmo cardiaco regresan a su estado de reposo y la tensión muscular se libera. Si una persona no ha tenido un orgasmo, la congestión de sangre puede causar malestar temporal. Esta sensación se va por sí sola, usualmente en menos de una hora, y no tiene efectos duraderos.
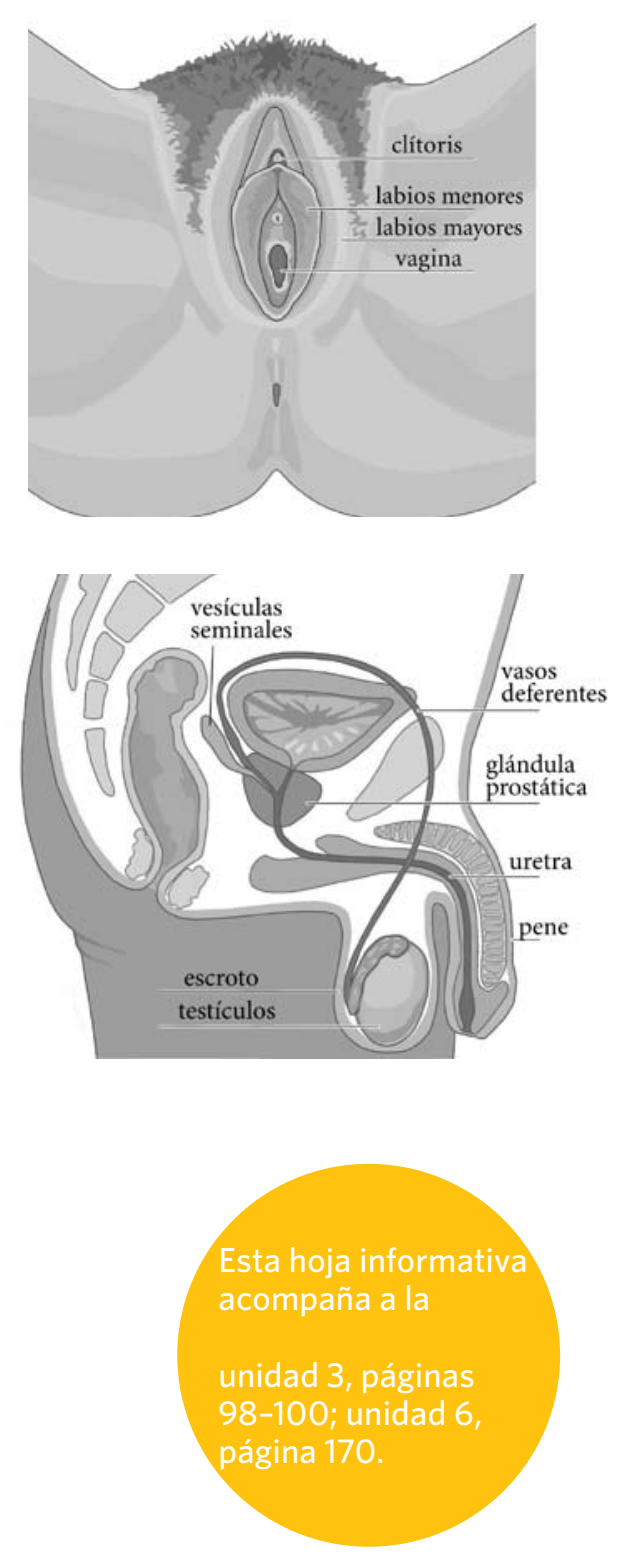


\section{anticoncepción de emergencia (AE)}

\section{¿Qué es la anticoncepción de emergencia?}

La anticoncepción de emergencia (AE) se refiere a los métodos para evitar el embarazo que pueden usarse después de una relación sexual sin protección. Por ejemplo, puede usarse después de la falla de un anticonceptivo (como en los casos de que un condón se rompe), el uso incorrecto de un método, después de haber tenido relaciones sexuales sin usar anticonceptivos, o después de una violación. La AE puede evitar el embarazo si se toma dentro de los cinco días posteriores a la relación sexual sin protección, pero funciona mejor mientras más pronto se toma después de la relación sexual. La AE no es un aborto.

\section{¿Qué métodos se usan para anticoncepción de emergencia?} Píldoras - Las píldoras que contienen progestina (una

hormona contenida en muchas píldoras anticonceptivas) son el método más común de AE. A partir de 2009, la recomendación es tomar una píldora que contenga $1.5 \mathrm{mg}$ de esta hormona o dos píldoras que contengan $.75 \mathrm{mg}$ cada una. Pueden ser tomadas en una dosis única o en dos dosis, la primera tan pronto como sea posible después de la relación sexual desprotegida; y, la segunda, 12 horas después. En algunos lugares, la $\mathrm{AE}$ viene pre-empaquetada en presentación de dos píldoras. Algunas veces se le llama "píldora de la mañana siguiente". Las píldoras anticonceptivas normales tomadas en dosis mucho más altas que de costumbre por un período corto de tiempo pueden también funcionar, pero la dosis depende del tipo y marca de la píldora y debe ser determinada por una o un prestador de servicios de salud informado.

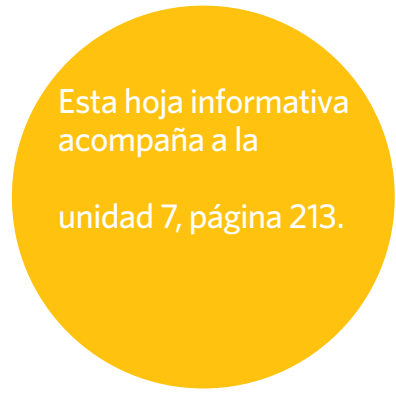

IUD - Otro método de anticoncepción de emergencia es el dispositivo intrauterino que libera cobre (DIU), el cual puede ser insertado por una o un prestador de servicios de salud capacitado, dentro de los cinco a siete días posteriores a la relación sexual sin protección. Sin embargo, el DIU no es apropiado para mujeres que estén en riesgo de una infección de transmisión sexual y, en algunos países, no ha sido aprobado para su uso en anticoncepción de emergencia.

\section{¿Cómo funcionan?}

Las píldoras de AE funcionan evitando la ovulación (ver hoja informativa sobre el Ciclo Menstrual), evitando que un óvulo y el esperma se unan; o evitando la implantación, a través de la cual un óvulo fecundado se adhiere al útero (ver hoja informativa sobre Reproducción y Embarazo). La AE no causa el aborto, pues no funcionará si la mujer ya está embarazada.

Se piensa que los DIU que liberan cobre operan interfiriendo con la implantación.

¿Qué tan efectiva es la anticoncepción de emergencia? La efectividad de las píldoras de anticoncepción de emergencia depende del tipo de píldora que se usa y qué tan pronto se toma después de la relación sexual desprotegida. Mientras más pronto se toma después de la relación sexual sin protección, es más efectiva. Las estimaciones sugieren que las píldoras de AE evitan el embarazo en hasta un 90 por ciento del tiempo. La inserción del DIU de emergencia es 99 por ciento efectiva.

\section{¿Protege la anticoncepción de emergencia contra las} infecciones de transmisión sexual?

La anticoncepción de emergencia no proporciona protección alguna contra infecciones de transmisión sexual ni el VIH. 
Los cánceres de los órganos reproductivos pueden afectar tanto a hombres como mujeres. Algunos de los cánceres reproductivos más comunes se describen enseguida.

\section{¿Qué cánceres reproductivos afectan a las mujeres?} En los países tanto desarrollados como en desarrollo, el cáncer de mama es el cáncer más común y mortal entre las mujeres; y representa 1 de cada 10 nuevos casos de cáncer en el mundo cada año. El cáncer cervical es el segundo tipo de cáncer más común, pero éste se presenta principalmente en los países en desarrollo; en donde, debido a un tamizaje limitado, ocurre en cuatro quintas partes de los casos y de las muertes relacionadas. Para todos los tipos de cáncer, el diagnóstico y tratamiento tempranos hacen que la cura sea más probable.

\section{¿Cómo funciona el tamizaje de cáncer de mama?}

El tamizaje de cáncer de mama se realiza mediante exámenes y mamografía. Las mujeres mayores de 20 años deben examinar sus mamas cada mes para familiarizarse con su sensación al tacto y buscar cambios. La secreción sanguinolenta o en forma de pus de los pezones o la presencia de abultamientos duros deben ser verificados por una o un prestador de servicios de salud. Las pautas para el tamizaje de cáncer de mama (exámenes y procedimientos clínicos) varían ampliamente, dependiendo de los factores de riesgo propios de la mujer y de los recursos clínicos locales. Los mamogramas son estudios de rayos $\mathrm{X}$ de las mamas que pueden detectar cambios que podrían indicar la presencia de cáncer. Sin embargo, los mamogramas no detectan todos los cánceres de mama y, en ocasiones, pueden detectar cambios que exámenes posteriores pueden determinar que en realidad no se trataba de cáncer. Si se encuentra un cambio, se practica una biopsia (análisis de laboratorio) para determinar si es cáncer. Ocho de cada diez abultamientos de mama no son cáncer. El cáncer de mama puede ser tratado con cirugía, radiación y/o quimioterapia (medicamentos).

\section{¿Cómo pueden las mujeres prevenir el cáncer cervical?}

La mayoría de casos de cáncer cervical son causados por ciertos tipos de virus del papiloma humano (VPH, ver la hoja informativa de ITS). El VPH puede ser evitado con una vacuna, preferentemente a edad temprana, antes de que la niña se vuelva sexualmente activa. Los condones también reducen el riesgo de la infección por VIH. Una prueba clínica (prueba de Pap) realizada durante un examen pélvico puede detectar células o lesiones pre-cancerosas, las cuales pueden tratarse con un procedimiento simple. Si es posible, las mujeres que son sexualmente activas deben ser tamizadas con regularidad.

\section{¿Qué es el cáncer ovárico?}

El cáncer ovárico es más frecuente en las mujeres mayores de 55 años y en mujeres que viven en países desarrollados. Con frecuencia, las mujeres no tienen síntomas hasta que el cáncer está relativamente avanzado. Los métodos para diagnosticar y tratar el cáncer ovárico están todavía en sus etapas iniciales.

\section{¿Qué cánceres reproductivos afectan a los hombres?}

El órgano reproductivo masculino que tiene mayor probabilidad de verse afectado por el cáncer es la glándula prostática. El cáncer de próstata afecta típicamente a hombres mayores y crece lentamente. El cáncer de testículo es más probable que afecte a los hombres jóvenes (18-35); sin embargo, el cáncer testicular es menos común y usualmente puede ser tratado si se le detecta en una fase temprana. Los hombres pueden también aprender a auto examinarse para identificar crecimientos anormales en los testículos. Algunas cepas de VPH (no aquellas que causan verrugas) pueden conducir al cáncer en el pene o el ano.

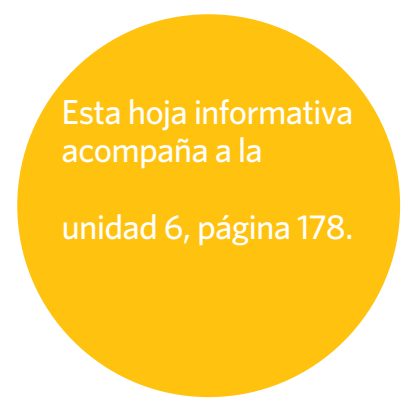




\section{ciclo menstrual (también llamado ciclo ovulatorio)}

\section{¿Qué es el ciclo menstrual u ovulatorio?}

En la pubertad, las niñas comienzan a experimentar ciclos de fecundidad. A diferencia de los hombres, que son fecundos de manera continua a partir de la pubertad, las mujeres sólo pueden embarazarse durante ciertos días del ciclo menstrual. La duración del ciclo varía de persona a persona, pero generalmente es de un mes. Durante cada ciclo, el cuerpo de la mujer atraviesa por muchos cambios. La parte más obvia de ciclo es el sangrado menstrual, también llamado menstruación o "período".

Con frecuencia pensamos en la menstruación como el clímax del ciclo, pero la menstruación es solamente una parte de un increíble conjunto de cambios que tienen lugar durante el ciclo. Todos estos cambios son la forma en que el cuerpo se prepara para un potencial embarazo. Incluyen la producción de mucosidad en el cuello del útero; el crecimiento y liberación de un óvulo; y cambios en el recubrimiento del útero. Todos estos cambios son controlados por hormonas (sustancias químicas naturales producidas por glándulas en el cuerpo y transportadas en el torrente sanguíneo).

Estos cambios hormonales afectan muchas partes del cuerpo, así como la forma en que las mujeres sienten y se desempeñan. Conocer sobre estos cambios puede dar a una niña o mujer un sentido de mayor comodidad y control sobre su propio cuerpo. Una mujer puede incluso aprender técnicas simples para identificar cuándo ella está ovulando y cuándo debe ocurrir su período menstrual.

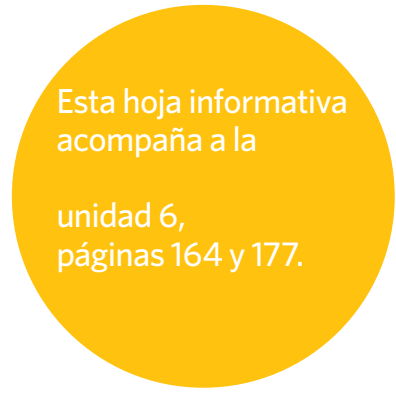

\section{¿Qué cambios experimenta el cuerpo durante el ciclo? Antes de la ovulación}

Sangrado Menstrual — La menstruación o sangrado menstrual indica el inicio de un nuevo ciclo. Durante la menstruación, sangre y tejido se desprenden del útero y fluyen hacia fuera de la vagina. El primer día de sangrado se designa como "día uno" del ciclo. Usualmente, el sangrado dura de cuatro a seis días.
Resequedad - Al finalizar el sangrado menstrual, la vagina puede sentirse seca debido a que los niveles de hormona son bajos y el cuello uterino produce poca o ninguna mucosidad.

\section{Secreción de mucosidad espesa / Engrosamiento de} recubrimiento uterino - Después de unos cuantos días, conforme el cuerpo libera más hormonas, una mujer (o niña) puede notar una secreción de mucosa vaginal. Al principio, esta secreción es de un color blancuzco o amarillento y puede tener una textura pegajosa. Al mismo tiempo, aunque ella no pueda detectarlo, el recubrimiento de su útero comienza a engrosarse y un óvulo (también llamado huevo) "madura".
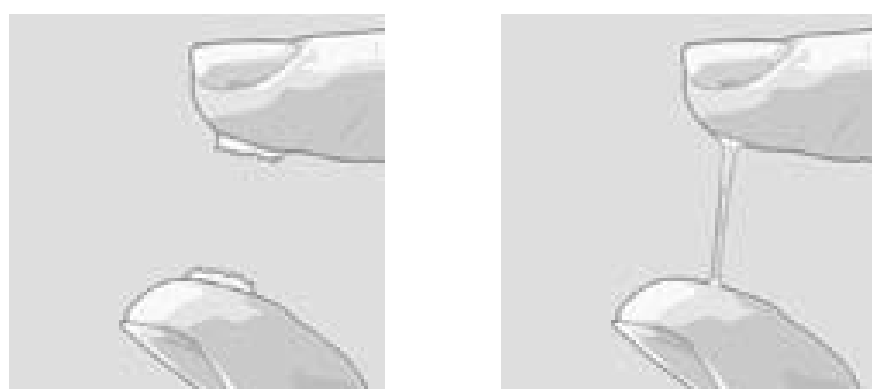

\section{Ovulación}

Mucosidad clara/ovulación - Al madurar el óvulo, la mucosidad se torna más clara y escurridiza, como una clara de huevo cruda. Con frecuencia puede estirarse entre los dedos. Esta mucosidad clara alimenta al esperma y le ayuda a subir hacia el óvulo. En este momento, el deseo sexual de la mujer puede aumentar también. La liberación del óvulo desde el ovario se llama ovulación. Los días justo antes y alrededor del momento de la ovulación son el tiempo en que una mujer o niña puede embarazarse. Algunas veces éstos son llamados sus "días fecundos". 
El cuerpo de la mujer también atraviesa por otros cambios alrededor de estos días. Por ejemplo, algunas mujeres experimentan un aumento en su deseo sexual y en su sentido de bienestar durante unos cuantos días. Y, algunas mujeres sienten una punzada o ligera incomodidad en uno de los lados de su abdomen, alrededor del momento en que el óvulo se impulsa fuera del ovario.

\section{Después de la ovulación}

Post ovulación - Después de la ovulación, el óvulo puede vivir por un día. La mucosa de nuevo se vuelve más espesa y cremosa o pegajosa. Durante los siguientes 14 días (más o menos), las hormonas mantienen en su lugar el recubrimiento engrosado del útero. La temperatura del cuerpo también aumenta ligeramente.

Sangrado Menstrual - Si al final de los 14 días no ha ocurrido un embarazo, los niveles de hormona se reducen. El recubrimiento del útero se desprende y la temperatura corporal disminuye de nuevo. Este desprendimiento es la menstruación y comienza un nuevo ciclo. (Si ocurre un embarazo, entonces el cuerpo continúa produciendo hormonas para mantener el recubrimiento del útero engrosado en su lugar durante 9 meses.)

\section{¿Cuánto dura el ciclo de ovulación y menstrual?}

Durante los primeros uno o dos años después de la menarquia (el primer período menstrual), el espacio de tiempo entre un período y el siguiente puede variar. Pueden pasar varios meses entre períodos. Aún para las mujeres adultas, la duración del ciclo puede variar de una mujer a otra. También puede variar de ciclo a ciclo para cualquier mujer. Puede verse afectado por factores como los viajes, el estrés, la depresión, la desnutrición y la enfermedad. Más comúnmente, sin embargo, las mujeres comienzan un nuevo ciclo cada 24-36 días.

La parte del ciclo desde el inicio del sangrado menstrual hasta la ovulación puede variar significativamente. Puede ser tan corto como un par de días, o tan largo como varios meses o más. Sin embargo, es más común que dure entre una y tres semanas. En contraste, la parte del ciclo desde la ovulación hasta el siguiente período menstrual no varía; es siempre muy cercano a 14 días. En otras palabras, una vez que ocurre la

ovulación, una niña o mujer sabe que - a menos que se haya embarazado - su período menstrual debe ocurrir en 14 días.

\section{¿Cuáles son los días fecundos del ciclo?}

El período fecundo incluye el día de la ovulación y los cinco días previos. El esperma puede sobrevivir en el tracto genital femenino hasta por cinco o seis días; y el óvulo (si no ha sido fecundado) sobrevive por hasta 24 horas. Sin embargo, es difícil predecir los días fecundos, dado que la primera fase del ciclo (desde la menstruación a la ovulación) es la parte que puede variar más ampliamente en duración. Algunas mujeres aprenden a observar los cambios en su mucosidad (y en su temperatura corporal) de tal forma que pueden saber cuándo es probable que estén ovulando. Algunas mujeres también sienten un ligero dolor cuando ovulan. Muchas mujeres y niñas usan técnicas "basadas en el conocimiento de la fecundidad" para tener una mejor idea de cuándo debe ocurrir su período menstrual. El conocer cuáles días son fecundos puede también ser útil para las mujeres que están tratando embarazarse, así como para quienes quieren evitar el embarazo. Sin embargo, el uso correcto de las técnicas basadas en el conocimiento de la fecundidad requiere una instrucción muy completa, seguimiento y una cuidadosa observación continua. [Ver también la hoja informativa sobre Métodos Anticonceptivos para mayor información sobre las técnicas basadas en el "conocimiento de la fecundidad".]

\section{¿Por cuánto tiempo las mujeres tienen ciclos menstruales} u ovulatorios?

Conforme las mujeres entran a la etapa de media vida, sus niveles de hormona pueden cambiar. Eventualmente, dejan de liberar óvulos y también cesa la menstruación. Esa fase, llamada menopausia, también señala el final de la fecundidad. La edad de la menopausia varía en cada mujer y difiere según los diferentes entornos; pero, típicamente, comienza a mediados de sus años cuarentas en los países en desarrollo; y a principio de sus años cincuentas en los países desarrollados.

[Ver también hoja informativa sobre Pubertad y Niñas.] 


\section{infecciones de transmisión sexual (ITS)}

\section{¿Qué son las infecciones de transmisión sexual?}

Las infecciones de transmisión sexual (ITS) son infecciones que se transmiten principalmente por contacto sexual, e incluyen las relaciones sexuales vaginales, orales o anales. Una variedad de diferentes organismos puede causar una ITS (ver cuadro siguiente). Ciertos parásitos como los piojos púbicos o ladillas y los ácaros que producen la sarna pueden transmitirse por contacto sexual. Las ITS son parte de un grupo más amplio de infecciones conocidas como infecciones del tracto reproductivo o ITR. [Ver hoja informativa sobre ITR.]

\section{¿Estas infecciones se transmiten solamente a través de la relación sexual?}

Algunas ITS pueden transmitirse a través del contacto piel a piel. Algunas son transmitidas a través del intercambio de fluidos corporales. Algunas pueden transmitirse al bebé antes de nacer, durante el parto o a través del amamantamiento.

\section{¿Cuáles son las consecuencias de las ITS?}

Las ITS pueden tener graves consecuencias tanto para los hombres como para las mujeres (ver cuadro siguiente). Sin embargo, muchas ITS comunes son difíciles de detectar en las mujeres; y algunas tienen consecuencias más serias para ellas. Por ejemplo, la propagación de la clamidia o gonorrea a los órganos reproductivos superiores es una causa común de la infecundidad en las mujeres. La infección con algunas ITS aumentan la probabilidad de contagiarse con o transmitir el

VIH. Algunas, pero no todas las ITS son curables. Otras, como el VIH, no lo son. El tratamiento temprano elimina o reduce las consecuencias de la mayoría de las ITS.

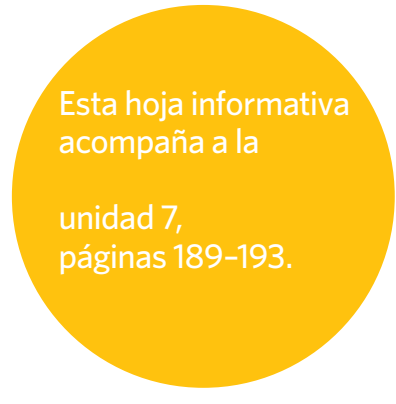

\section{Cómo puede la gente prevenir las ITS?}

- Determinar si se tiene una ITS mediante una prueba realizada por un prestador de servicios de salud.

- Si se tiene una ITS, obtener tratamiento y notificar a todas las parejas sexuales recientes para que también se examinen.
- Averiguar si su pareja tiene una ITS; en cuyo caso, debe asegurarse de que él o ella se someta a tratamiento.

- Conversar con su pareja acerca de la manera de tener intimidad sexual de tal forma que no implique riesgo de transmitir una infección.

- Usar condones masculinos o femeninos y evitar el contacto sexual que permitiría la transmisión de una infección. (Los condones protegen contra la mayoría de las ITS — incluido el VIH - pero no contra todas.)

- Vacunarse contra las ITS que pueden ser prevenidas. En la actualidad, hay vacunas contra la Hepatitis B y contra el Virus del Papiloma Humano (VPH).

\section{¿Cuándo debe una persona hacerse una prueba de ITS?}

Una persona está en riesgo de contraer una ITS y debe hacerse una prueba si tiene una o más de las siguientes condiciones:

- síntomas de una ITS;

- una pareja sexual que tiene una ITS o que tiene signos de tener una ITS

- más de una pareja sexual;

- una nueva pareja en los últimos 3 meses;

- una pareja que tiene o puede tener otras parejas sexuales;

- una pareja que vive en otra parte o que viaja con frecuencia.

Las pruebas tempranas son importantes. Una persona a la que se le diagnostica con una ITS puede obtener tratamiento y puede ayudar a que sus parejas recientes también se hagan la prueba. Una pareja no debe reanudar la actividad sexual hasta que ambos miembros de la pareja se hayan hecho la prueba $y$, en caso necesario, hayan completado el tratamiento. Debido a que algunas ITS no resultan positivas inmediatamente en las pruebas, algunas veces es necesario repetir la prueba. 


\begin{tabular}{|c|c|c|c|c|}
\hline ITS & Síntomas para las mujeres & Sintomas para los hombres & ¿Puede curarse? & ¿Hay una vacuna? \\
\hline Chancroide & \multicolumn{2}{|c|}{$\begin{array}{l}\text { Irritación dolorosa en los genitales; nódulos linfáticos inflamados en la } \\
\text { ingle. Condición con frecuencia asintomática en las mujeres. }\end{array}$} & Sí & No \\
\hline Clamidia & $\begin{array}{l}\text { Asintomática en la mayoría de las } \\
\text { mujeres. Las mujeres que sí tienen } \\
\text { síntomas pueden presentar secreción } \\
\text { vaginal anormal o una sensación de } \\
\text { ardor al orinar. }\end{array}$ & $\begin{array}{l}\text { Con frecuencia asintomática. Los } \\
\text { hombres con síntomas pueden } \\
\text { presentar secreción tipo pus del } \\
\text { pene o una sensación de ardor al } \\
\text { orinar. }\end{array}$ & $\begin{array}{l}\text { Sí. Pero si no se sujeta a tratamiento en las mu- } \\
\text { jeres, puede conducir a la enfermedad inflamato- } \\
\text { ria pélvica (EIP), la que a su vez puede producir } \\
\text { infecundidad. Las complicaciones } \\
\text { en los hombres son poco comunes. }\end{array}$ & No \\
\hline Gonorrea & $\begin{array}{l}\text { La mayoría de las mujeres son } \\
\text { asintomáticas; secreción vaginal } \\
\text { anormal o una sensación de ardor al } \\
\text { orinar. }\end{array}$ & $\begin{array}{l}\text { Los hombres con frecuencia } \\
\text { experimentan secreciones o ardor } \\
\text { al orinar. Algunos hombres no } \\
\text { experimentan síntomas. }\end{array}$ & $\begin{array}{l}\text { Sí. Pero si no se sujeta a tratamiento puede con- } \\
\text { ducir a la EIP en las mujeres; y puede conducir a la } \\
\text { infecundidad tanto en mujeres como en hombres. }\end{array}$ & No \\
\hline Hepatitis B & \multicolumn{2}{|c|}{$\begin{array}{l}\text { Algunas personas experimentan síntomas parecidos a la influenza e } \\
\text { ictericia y orina de color oscuro; otras no experimentan síntomas. }\end{array}$} & $\begin{array}{l}\text { Aunque no se ha encontrado un medicamento que } \\
\text { cure la hepatitis B, en muchos casos el cuerpo elim- } \\
\text { ina la infección por sí solo. Ocasionalmente puede } \\
\text { convertirse en una enfermedad hepática crónica. } \\
\text { Los niños pequeños y los infantes están en mucho } \\
\text { mayor riesgo de quedar infectados crónicamente. }\end{array}$ & Sí \\
\hline $\begin{array}{l}\text { Herpes (virus } \\
\text { herpes simplex) }\end{array}$ & \multicolumn{2}{|c|}{ Episodios recurrentes de irritación dolorosa en los genitales o el ano. } & $\begin{array}{l}\text { No, pero los síntomas pueden controlarse a través } \\
\text { del tratamiento. }\end{array}$ & No \\
\hline $\begin{array}{l}\text { Virus de la inmuno- } \\
\text { deficiencia humana } \\
\text { (VIH) }\end{array}$ & \multicolumn{2}{|c|}{$\begin{array}{l}\text { Por lo general, el VIH no presenta síntomas en sus etapas tempranas. El } \\
\text { VIH conduce al SIDA. Las personas que viven con el SIDA pueden sufrir } \\
\text { varias infecciones, cánceres y otras dolencias que representan un riesgo } \\
\text { de vida. }\end{array}$} & $\begin{array}{l}\text { No, el SIDA es una enfermedad crónica y ulti- } \\
\text { madamente fatal, pero el tratamiento (terapia } \\
\text { antirretroviral) retrasa dramáticamente el avance } \\
\text { de la enfermedad. }\end{array}$ & No \\
\hline $\begin{array}{l}\text { Virus del Papiloma } \\
\text { Humano (VPH) }\end{array}$ & \multicolumn{2}{|c|}{$\begin{array}{l}\text { El VPH puede ser asintomática. Algunas cepas pueden causar verrugas } \\
\text { genitales. Otros conducen al cáncer. Esto incluye cánceres de la cabeza, el } \\
\text { cuello y el ano; cáncer de pene en los hombres; y — más comúnmente - } \\
\text { cáncer de cuello del útero en las mujeres. }\end{array}$} & $\begin{array}{l}\text { No, pero los síntomas pueden controlarse a través } \\
\text { del tratamiento. Algunas cepas pueden desarrollar } \\
\text { cáncer cervical en las mujeres. }\end{array}$ & $\begin{array}{l}\text { Sí. Vacunas contra el VPH } \\
\text { puede proteger ambos sexos } \\
\text { contra muchas cepas del virus. }\end{array}$ \\
\hline Sífilis & \multicolumn{2}{|c|}{$\begin{array}{l}\text { Comienza con una irritación indolora de los genitales, del recto o boca. } \\
\text { La segunda etapa puede presentar sarpullido, lesiones en las membranas } \\
\text { mucosas, fiebre y malestar general. La etapa latente comienza cuando } \\
\text { estos síntomas desaparecen. }\end{array}$} & $\begin{array}{l}\text { Sí. Si se trata en las etapas tempranas. Sin } \\
\text { tratamiento, la infección permanece en el cuerpo. } \\
\text { La etapa tardía de la sífilis incluye daño de órga- } \\
\text { nos internos y puede causar la muerte. }\end{array}$ & No \\
\hline $\begin{array}{l}\text { Tricomoniasis (tri- } \\
\text { comonas o tric) }\end{array}$ & $\begin{array}{l}\text { Las mujeres pueden experimentar } \\
\text { secreción vaginal amarillenta- } \\
\text { verdosa y espumosa, con un fuerte } \\
\text { olor. También, puede causar picazón } \\
\text { o incomodidad durante la relación } \\
\text { sexual y al orinar. }\end{array}$ & $\begin{array}{l}\text { Usualmente los hombres son } \\
\text { asintomáticos; algunas veces } \\
\text { pueden tener secreción leve o } \\
\text { ligera sensación de ardor al orinar } \\
\text { o eyacular. }\end{array}$ & Sí & No \\
\hline
\end{tabular}




\section{infecciones del tracto reproductivo que no son transmitidas sexualmente}

\section{¿Qué son las infecciones del tracto reproductivo?}

Las infecciones del tracto reproductivo (ITR) tienen tres causas principales:

- transmisión sexual [ver las hojas informativas sobre ITS y sobre VIH);

- cuando accidentalmente se introduce o propaga una infección durante un procedimiento médico como la inserción de un DIU o durante el parto); y

- crecimiento excesivo de organismos que normalmente están presentes en la vagina. Las infecciones más comunes de este tipo, mismas que se conocen como infecciones endógenas, son la candidiasis y la vaginosis bacteriana.

\section{¿Qué es la candidiasis?}

Candidiasis, también llamada infección por levadura, cándida o afta, es resultado de un aumento natural de levadura en la vagina. Los signos incluyen una secreción blanca espesa; picazón intensa o enrojecimiento de la vulva y vagina; e incomodidad durante la relación sexual. En ocasiones una mujer puede tener candidiasis y no presentar síntomas. La candidiasis responde al tratamiento. Las mujeres cuyos sistemas inmunes son débiles, que están embarazadas, o que están tomando antibióticos, tienen mayor probabilidad de desarrollar candidiasis. Los hombres ocasionalmente tienen picazón e incomodidad debido a la candidiasis. En ocasiones, las personas contraen infecciones por candidiasis en otras partes húmedas del cuerpo.

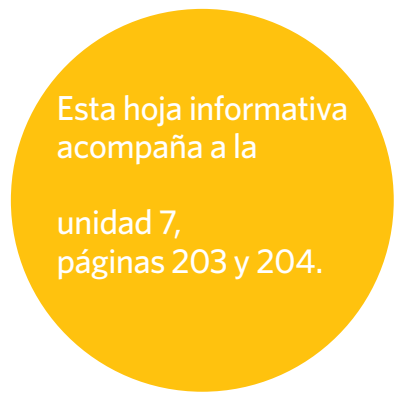

de la mitad de las mujeres que tienen VB no tienen síntoma alguno. La VB responde al tratamiento. Aunque usualmente no causa complicaciones, puede ser grave, lo que conduce a una mayor susceptibilidad al VIH y a otras ITS, enfermedad pélvica inflamatoria [ver hoja informativa sobre ITS]; y, en las mujeres embarazadas, a un mayor riesgo de parto prematuro o bajo peso al nacer.

\section{¿Qué puede hacerse para disminuir la ocurrencia de infecciones del tracto reproductivo que son transmitidas por medios distintos a la relación sexual?}

Las mujeres deben evitar las duchas vaginales; el uso en el interior de la vagina de hierbas, agentes o productos para "secar" o "estrechar"; y el uso innecesario de antibióticos. Después de utilizar el inodoro, las mujeres deben siempre limpiarse del frente hacia atrás (desde donde sale la orina hacia el ano) para evitar que los gérmenes se propaguen del ano a la vagina u orificio urinario. Debe evitarse la ropa interior sintética (poliéster) y los pantalones apretados que restringen la circulación de aire.

\section{¿Cómo pueden las infecciones del tracto reproductivo} resultar de un procedimiento médico?

Las ITR pueden ser causadas cuando un instrumento no estéril es introducido en el útero; o cuando mediante el uso de algún instrumento se introduce dentro del útero una infección vaginal o cervical existente, en donde puede propagarse. Este tipo de ITR puede ser causado por procedimientos como los abortos o inserciones de DIU, o durante el parto. Si se dejan sin tratamiento, puede desarrollarse una condición grave llamada enfermedad pélvica inflamatoria. Los servicios médicos deben mantener condiciones estériles durante tales procedimientos. Es esencial realizar pruebas para detectar infecciones existentes (y darles tratamiento), antes de insertar un instrumento a través del cuello uterino. 


\section{infecundidad y reproducción asistida}

\section{¿Qué es la infecundidad?}

Se dice que una pareja es infecunda si no puede lograr un embarazo después de tener relaciones sexuales desprotegidas con regularidad durante un año, aún si ha tenido hijos con anterioridad. Alrededor de una de cada diez parejas tiene problemas para lograr un embarazo.

\section{¿Cuáles son las principales causas de la infecundidad y} qué puede hacerse para protegerse contra ella?

Aunque con frecuencia se culpa a la mujer de la infecundidad, aproximadamente la mitad de las veces el hombre es infecundo, o ambos miembros de la pareja pueden contribuir al problema. Las principales causas de la infecundidad femenina incluyen el bloqueo tubárico (por ejemplo, debido a una ITS no tratada o a otra condición, como la endometriosis) y problemas hormonales. Las principales causas de la infecundidad masculina son problemas con la producción de suficiente esperma saludable (lo que puede deberse a varios factores). Para protegerse contra la infecundidad causada por las ITS, use un condón cuando no se desee un embarazo. La edad puede también ser un factor. Las personas, especialmente las mujeres, se vuelven menos fecundas con la edad. La fecundidad de la mujer disminuye significativamente después de los 35 años.

\section{¿Cuál es el primer curso de acción para enfrentar los}

\section{problemas de fecundidad?}

Primero, la pareja debe determinar los períodos de fecundidad de la mujer y tener relaciones sexuales cuando su mucosidad es abundante, clara, escurridiza y elástica. Deben tratar cualquier problema de salud existente, comer y descansar bien, así como evitar el tabaco, las drogas, el alcohol y la cafeína. En una clínica puede examinarse el semen del hombre para determinar si tiene suficiente esperma y también puede examinarse su escroto para detectar la presencia de alguna vena varicosa que podría afectar la producción de esperma. La mujer puede ser examinada para ver si tiene alguna condición o infección que pudiera ser sujeta a tratamiento.

\section{¿Qué otros tratamientos hay para la infecundidad?}

Otros tratamientos dependen de la causa de la infecundidad.

Si la mujer no está ovulando, los medicamentos para estimular la fecundidad pueden ayudar. Si un conducto tubárico está

bloqueado o si hay otras condiciones, la cirugía puede ayudar. Si un hombre tiene una vena varicosa en su escroto que esté afectando a su esperma, la cirugía puede ayudar a corregir esta condición.

\section{¿Qué es la reproducción asistida?}

La reproducción asistida consiste en el uso de varias técnicas avanzadas para ayudar a la fecundación. La inseminación artificial involucra la inserción del semen masculino en la vagina de la mujer, cuando está ovulando. La fecundación in vitro implica la unión de óvulos y esperma en un recipiente de laboratorio y, posteriormente, la inserción del óvulo u óvulos fecundados en el útero de la mujer. Otra práctica es la "subrogación" o "sustitución" en la que algunas parejas hacen un arreglo con una "madre substituta", que acepta llevar un embarazo en sustitución de una mujer que no puede hacerlo por sí misma (usualmente a través de la fecundación in vitro). Tales técnicas complicadas de reproducción asistida son extremadamente costosas.

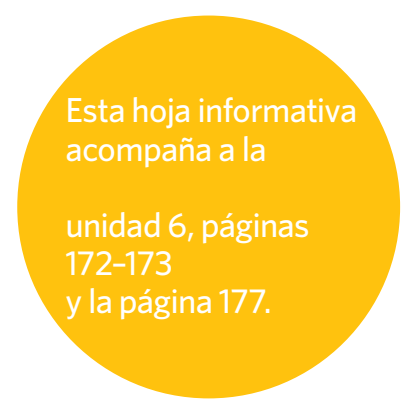




\section{métodos anticonceptivos}

\section{métodos temporales "controlados por la persona usuaria" que bloquean la llegada del esperma al óvulo}

\section{MÉTODO \\ Qué es y cómo trabaja}

Condón masculino

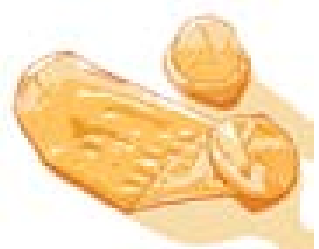

Condón femenino

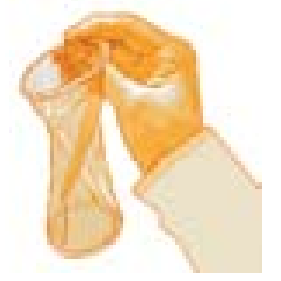

Diafragma y tapón cervical

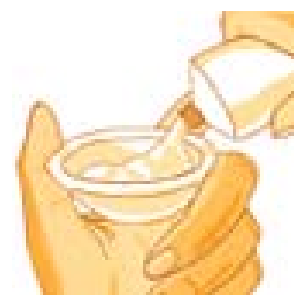

Espermicidas

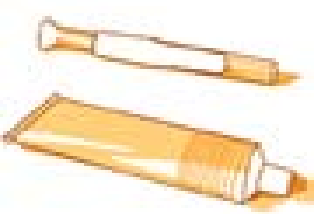

Funda de látex delgado que se desenrolla sobre el pene erecto antes de la relación sexual y que evita que el esperma entre en la vagina.

\section{¿Protege contra} ITS/VIH?

Sí

Funda de plástico lubricado con dos anillos, uno de los cuales permanece fuera de la vagina cubriendo parte de los labios y el otro es colocado dentro de la vagina cubriendo el cuello uterino. Forma una bolsa que capta el semen.
Sí

C20

\section{Otras características}

Es uno de los dos métodos que ofrecen protección doble contra el embarazo y la infección, de esta forma protegiendo también contra la infecundidad y el cáncer cervical.

Permite que hombres adultos y jóvenes se protejan a sí mismos y

protejan a sus parejas.

Son de fácil obtención.

Deben colocarse durante la actividad sexual previo al coito.

Algunas personas encuentran que el condón reduce la sensación. Puede romperse o tener fugas, especialmente si se usa incorrectamente.

Puede insertarse horas antes de que comience la actividad sexual. Permite que mujeres adultas y jóvenes se protejan a sí mismas y protejan a sus parejas.

Su presencia es notoria durante la relación sexual y la inserción puede requerir práctica.

Su costo es alto en comparación con los condones masculinos.

Nota: Esta hoja informativa acompaña el contenido de la unidad 7, páginas 210-213.

Para información adicional, incluidos los efectos secundarios, efectividad y forma de uso, ver <http://info.k4health.org/globalhandbook/SpanishHandbook.pdf>.

Diafragma: Capuchón de goma poco profundo y suave, que se llena con espermicida y se inserta dentro de la vagina antes de la relación sexual. Cubre el cuello del útero para evitar que el esperma entre; y el espermicida se encarga de matar el esperma.

Tapón cervical: Capuchón de látex en forma de dedal que se inserta dentro de la vagina, se coloca ajustadamente sobre el cuello uterino y se mantiene en su lugar por succión, con el fin de bloquear el paso del esperma. Se recomienda su uso junto con un espermicida.
Todavía no se sabe si el tapón o el diafragma ofrece alguna protección contra las infecciones.
Puede insertarse antes de que comience la actividad sexual. No está disponible ampliamente.

Se puede salir de su lugar durante la relación sexual.

El tamaño apropiado debe ser determinado por un prestador de servicios de salud.
Productos químicos en forma de espuma, crema, jalea, película soluble o supositorio que se insertan en la vagina, creando una barrera física y matando el esperma. Un espermicida puede usarse por sí solo o con un método de barrera, como los condones, para aumentar su efectividad.
El uso repetido de espermicidas a base de nonoxynol (N-9) puede conducir a lesiones genitales, lo cual aumenta el riesgo de transmisión del VIH.

Las mujeres con alto riesgo de infección por VIH no deben usarlos. Algunos pueden ser incómodos por la suciedad que generan. 


\section{métodos de acción prolongada que actúan al interior del sistema corporal}

\section{MÉTODO \\ Anticonceptivos orales ("la píldora")

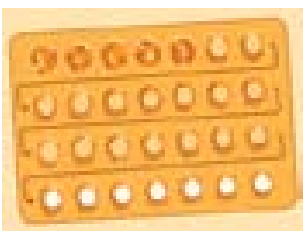

\section{Qué es y cómo trabaja}

Pequeñas píldoras de hormonas sintéticas (estrógeno y progestágeno, o solamente progestágeno) que evitan la ovulación e interfieren en la migración del esperma al aumentar el espesor del moco cervical. Las mujeres las toman diariamente por vía oral ya sea por 21 o 28 días dependiendo de su marca y tipo.
¿Protege contra ITS/VIH?

No

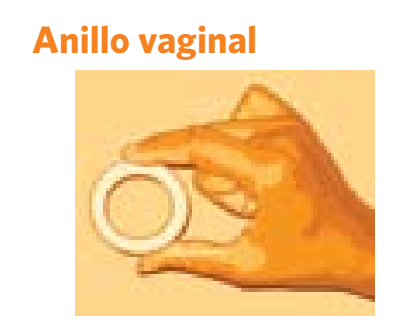

Inyección que se aplica a intervalos regulares, usualmente de 1 a 3 meses; y que contiene progestágeno, una hormona sintética que evita la ovulación y hace que el moco cervical se haga más espeso.

Anillo delgado, suave y flexible que la mujer inserta en su vagina. Libera lentamente estrógeno y progestágeno, deteniendo la ovulación y espesando el moco cervical.

\section{Otras características}

No requiere que la mujer inserte o aplique el método al momento de las relaciones sexuales.

Puede reducir los cólicos menstruales y el riesgo de ciertos tipos de cáncer, anemia, problemas de las mamas y la enfermedad inflamatoria pélvica.

La mujer debe recordar tomar la píldora diariamente.

Típicamente hay un rápido retorno a la fecundidad después de que la mujer deja de tomar la píldora.
Parche anticonceptivo

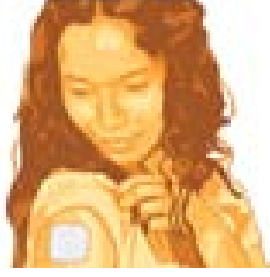
libera lentamente progestágeno y estrógeno a través de la piel, para evitar la ovulación y espesar el moco cervical.

Una o dos barras pequeñas y suaves que se implantan

col brazo de la mujer y que, en form

largo de un período de 3 a 5 años. Espesa el moco cervical e inhibe la ovulación.
No requiere que la mujer inserte o aplique el método al momento de las relaciones sexuales.

Es menos efectivo para mujeres que pesan más de 90 kilos (198lbs). Después de que la mujer deja de usarlo, la fecundidad regresa rápidamente.

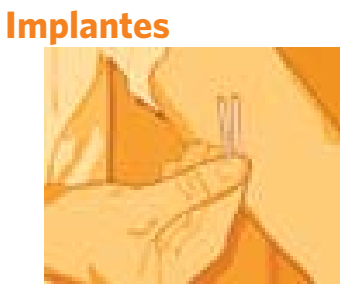

Puede usarse sin que otras personas lo sepan.

No requiere que la mujer inserte o aplique el método al momento de las

Puede disminuir el riesgo de ciertos tipos de cáncer.

El retorno a la fecundidad puede tardar algunos meses después de suspender su uso.

No requiere que la mujer inserte o aplique el método al momento de las relaciones sexuales.

Hay un retorno inmediato a la fecundidad al suspender su uso. 
Dispositivos

Intrauterinos (DIU)

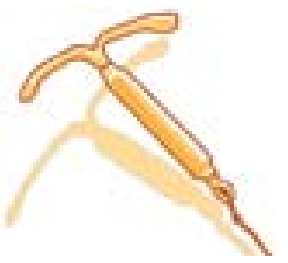

Los DIU son pequeños dispositivos, comúnmente en forma de $\mathrm{T}$, que un prestador de servicios de salud inserta en el útero. Algunos DIU liberan progestágeno (una hormona), mientras que otros están recubiertos de cobre, que tiene efectos anticonceptivos. Evitan que el esperma llegue al óvulo. Algunos tipos de DIU pueden funcionar hasta por 10 años. durante el coito.

Si hay una infección presente durante la inserción, o si las condiciones para la inserción no son estériles, la inserción puede derivar en una infección pélvica y un aumento del riesgo de infecundidad.

El cuerpo algunas veces expulsa el DIU.

Debe ser insertado y retirado por una o un prestador de servicios de salud capacitado.

\section{"métodos de comportamiento" - requieren de conductas específicas basadas en la comprensión y buen funcionamiento de su cuerpo}

\section{MÉTODO}

Método de Lactancia Amenorrea

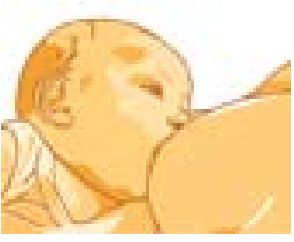

\section{Retiro}

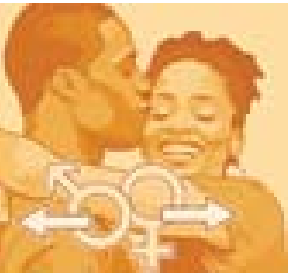

Método del moco cervical

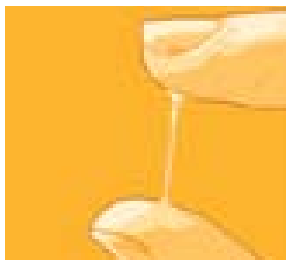

\section{Qué es y cómo trabaja}

Aplicable solamente para mujeres que están amamantando. El amamantamiento causa que el cuerpo produzca hormonas que pueden evitar la ovulación. Como anticonceptivo, este método es efectivo solamente durante los primeros seis meses de amamantamiento o hasta que la mujer ha reanudado su menstruación (lo que ocurra primero); y solamente si el bebé es alimentado exclusivamente con leche materna y cuando lo pide.

\section{¿Protege contra} ITS/VIH?

No
Consiste en sacar el pene de la vagina y retirarlo antes de eyacular para evitar que el esperma entre en la vagina.

Este método puede ser efectivo si se usa correcta y consistentemente.

\section{No} varse cuando se hace limpieza después de orinar, o sobre la ropa interior. El tipo y cantidad de esta mucosidad cambia durante el ciclo menstrual. Una mujer puede aprender a distinguir cuál tipo de mucosidad indica que está probablemente en sus días fecundos y cuál tipo indica que está fuera de ese período. Durante los días fecundos, ella puede usar un método anticonceptivo de barrera, o puede abstenerse de tener relaciones sexuales. [Ver hoja informativa sobre el Ciclo Menstrual.]

\section{Otras características}

El amamantamiento es gratuito y tiene efectos positivos para la madre el bebé.

El método de lactancia amenorrea (MELA) puede ser difícil de usar por las mujeres que habitualmente necesitan estar alejadas de sus bebés.

El retiro siempre está disponible y es gratuito.

Es considerablemente más efectivo que no retirarse

Depende del autocontrol y habilidad del hombre para predecir la eyaculación. Las mujeres no tienen control de este método.

Se interrumpe la relación sexual y puede disminuir el placer.

\section{No}

Este método aumenta el nivel de conciencia de la mujer y la comprensión sobre su cuerpo.

Permite a una mujer predecir cuándo comenzará su próximo ciclomenstrual. También puede ayudar a las parejas que están tratando de lograr un embarazo a identificar los días más fecundos del ciclo.

El método es aceptable para grupos religiosos que desaprueban el uso de otros métodos.

Aprender el método requiere tiempo, la disciplina para mantener la observación diaria de la mucosidad y la cooperación de la pareja de la mujer. 


\section{Método de la}

temperatura corporal

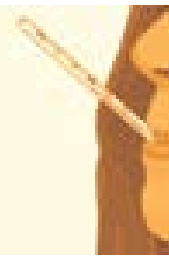

La temperatura del cuerpo de la mujer aumenta con la

ovulación. Al tomarse la temperatura cada mañana an-

tes de levantarse de la cama o moverse, ella puede identi-

ficar cuándo ha ocurrido la ovulación. No se puede

predecir la ovulación, pero unos cuantos días después de

ocurrida la ovulación, la mujer sabe que no es fecunda

por el resto del ciclo. Hasta que ocurre la ovulación,

ella puede usar un método anticonceptivo de barrera, o

puede abstenerse de tener relaciones sexuales.
No

Muchas mujeres tienen ciclos menstruales que son

bastante predecibles en términos de la periodicidad con

la que inicia un nuevo ciclo. Los Cuenta Ciclos (usados para el Método de Días Estándar) y el método del Calen-

dario son dos métodos que las mujeres pueden usar para

identificar los días fecundos durante los cuales pueden

abstenerse o usar un método anticonceptivo de barrera.
No

Este método es más práctico para mujeres que tienen ciclos regulares.

Puede también ayudar a parejas que están tratando de lograr un emba-

razo a identificar los días más fecundos del ciclo.

Requiere la cooperación de la pareja de la mujer.

\section{métodos quirúrgicos permanentes}

\section{MÉTODO \\ Qué es y cómo trabaja \\ ¿Protege contra \\ ITS/VIH? \\ Otras características}

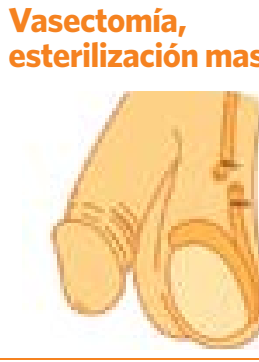

Esterilización femenina, esterilización tubaria

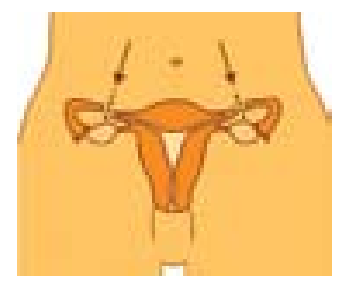

Operación ambulatoria sencilla para cortar y ligar los vasos deferentes. El esperma es entonces reabsorbido sin causar daño alguno en el cuerpo del hombre, en vez de incorporarse al semen. No cambia la capacidad del hombre para tener relaciones sexuales, sentir placer sexual o eyacular.

\section{No}

La vasectomía no es efectiva sino hasta después de tres meses posteriores a la cirugía.

Este es un método permanente.
Procedimiento quirúrgico para cortar y ligar (ligadur tubaria) o bloquear las trompas de Falopio, para evitar que el esperma y el óvulo se encuentren. No cambia la capacidad de la mujer para tener relaciones sexuales o sentir placer sexual. 


\section{mutilación genital femenina}

\section{¿Qué es la mutilación genital femenina?}

La mutilación genital femenina (MGF), también conocida como corte genital femenino o circuncisión femenina, se refiere a la remoción parcial o total de los genitales femeninos externos. Se realiza a diferentes edades, más comúnmente alrededor de los siete a diez años. Puede incluir alguna o todas las siguientes prácticas:

- remoción total o parcial del clítoris;

- corte total o parcial del clítoris y de los labios interiores de la vulva;

- cierre por sutura de los dos lados de la vulva, dejando un pequeño orificio para permitir el paso de la orina y el flujo menstrual, que es un procedimiento llamado infibulación; y

- otras prácticas dañinas, como la perforación, estiramiento o quemado del clítoris y labios; raspado o corte del tejido vaginal; o la aplicación de sustancias corrosivas dentro de la vagina para causar sangrado o estrechamiento.

\section{¿Cuáles son las consecuencias de la MGF para la salud?}

La MGF con frecuencia tiene serias consecuencias físicas, sexuales y para la salud mental, las cuales varían según el tipo de procedimiento, las condiciones en las que se lleva a cabo y la condición física de la niña o mujer. Las consecuencias inmediatas pueden incluir infección, sangrado, fuerte dolor, conmoción, problemas urinarios y daños a los tejidos.

El sangrado excesivo y la infección pueden conducir a la muerte. A la larga, la MGF puede causar dificultades para la menstruación, la relación sexual y el placer, fecundidad, parto, excreción de orina y heces, así como para la salud mental, incluidos el miedo y la depresión.

\section{¿Por qué se realiza la MGF?}

Las razones que se argumentan para justificar el

procedimiento varían, pero con frecuencia se relacionan con la tradición y con el mantenimiento de las normas de género prevalecientes. Como un rito de iniciación tradicional, la MGF significa la aceptación de la niña en la sociedad y su elegibilidad para el matrimonio. Otras razones específicas incluyen: reducir el deseo sexual para que las niñas y mujeres no tengan relaciones sexuales fuera del matrimonio; reforzar la identidad cultural; cumplir con actitudes culturales locales sobre lo que es "atractivo"; y por razones religiosas, aunque ninguna religión requiere la aplicación de este procedimiento.

\section{¿En dónde se practica la MGF? ¿Cuántas mujeres se ven} afectadas?

La MGF se practica en 28 países africanos y en varios países de Asia y el Medio Oriente, así como entre poblaciones inmigrantes en Europa, Australia, Canadá y los Estados Unidos, y también entre algunos grupos étnicos de América Central y América del Sur. Se estima que entre 100 y 140 millones de niñas, adolescentes y jóvenes han sido sometidas a mutilación genital femenina y que entre dos y tres millones de otras niñas están en riesgo cada año.

\section{¿Cuáles derechos humanos viola la MGF?}

La MGF es una forma de violencia en contra de las niñas y las mujeres. Viola o pone en peligro el goce del derecho a la vida; el derecho a la integridad física; el derecho al más alto nivel posible de salud; el derecho a vivir libres de trato cruel, inhumano o degradante, incluida la violencia física o mental lesiones o abusos; el derecho a vivir con dignidad, libre de la discriminación de género; y los derechos de la niña al desarrollo, protección y participación.

\section{¿Qué se está haciendo para terminar con la MGF?}

La Organización Mundial de la Salud, el UNICEF y el UNFPA, así como muchas ONG están trabajando para poner fin a la MGF. Muchos países y comunidades la han prohibido. 


\section{nutrición}

\section{¿Por qué es especialmente importante la nutrición durante} la adolescencia?

La nutrición adecuada es especialmente importante durante la adolescencia porque es un período de rápido crecimiento. Las niñas que dan a luz y amamantan durante la adolescencia, requieren una considerable nutrición adicional.

\section{¿Cuáles son las principales causas de los problemas nutricionales y sus consecuencias?}

La falta de acceso a suficientes alimentos nutritivos debido a la pobreza es la principal causa de los problemas nutricionales. Estos problemas empeoran cuando existe una desigual distribución de alimentos dentro de las familias; por ejemplo, cuando los hijos varones reciben más alimentos nutritivos que las hijas, o cuando las viudas y las hijas son alimentadas al último. La nutrición inadecuada afecta las capacidades de aprendizaje. Disminuye la resistencia a las infecciones. Conduce a problemas de salud materna e infantil; $y$, en muchos casos, a la muerte. Y puede resultar en huesos débiles o quebradizos en personas de mediana edad o ancianas.

Otros problemas nutricionales son más comunes en los países desarrollados. Comer demasiados alimentos altos en grasa y azúcar conduce a la obesidad y contribuye a numerosos problemas de salud, que incluyen la diabetes, la hipertensión y las enfermedades cardiacas. Sujetarse a dietas compulsivas también es un problema para muchas personas, especialmente cuando los medios crean y promueven ideales poco realistas acerca del tamaño y apariencia corporal. Los desórdenes alimenticios como la anorexia (alimentarse deficientemente en forma compulsiva) y la bulimia (usualmente vómito, pero también la ingesta de laxantes, después de comer) pueden conducir a enfermedades graves e incluso la muerte. Estos problemas son más comunes en las niñas.

\section{¿Qué puede hacerse para mejora la nutrición?}

Algunas formas para mejorar la nutrición incluyen:

- aprender sobre el contenido nutricional de los alimentos y tomar decisiones saludables al respecto;
- exigir que los mercados o centros de distribución de comida rápida ofrezcan opciones económicas y saludables;

- organizar mercados de productores agrícolas para que las personas residentes en los barrios urbanos tengan acceso a alimentos frescos de la localidad;

- promover la justa distribución de alimentos entre todos los miembros de la familia;

- apoyar el etiquetado preciso y claro de los productos alimenticios; y

- monitorear las prácticas publicitarias de la "comida rápida".

\section{actividad física}

\section{¿Por qué es importante la actividad física?}

Una cantidad y tipo de actividad física saludable ayuda a proteger contra enfermedades como la obesidad, diabetes, ciertos cánceres y la presión arterial alta; y mejora el bienestar psicológico. Los deportes son también fuente de interacción social y diversión. Para las niñas, la participación en deportes o programas de ejercicios pueden fomentar el desarrollo de una imagen positiva y ofrecer oportunidades para construir amistades, actividades colectivas vigorosas y el reconocimiento público de sus logros. Las niñas adolescentes que practican deportes pueden tener mejores resultados sociales y de salud - incluidos un mejor desempeño académico y menos embarazos no planeados - que quienes no lo hacen.

\section{¿Cómo afectan los estereotipos la participación en la}

\section{actividad física y los deportes?}

Todas las personas merecen iguales oportunidades para participar en deportes o actividad física, sin importar el nivel de habilidad, género, capacidad física o condición económica. Sin embargo las personas que viven con discapacidades en condiciones de pobreza extrema con frecuencia carecen de oportunidades para practicar deportes. Además, las actitudes sesgadas sobre el género han resultado en menores oportunidades de ejercicio y deportes para las niñas. Los ejemplos de esto incluyen los equipos deportivos escolares se ofrecen solamente para los niños; un menor acceso o instalaciones y equipos de inferior calidad para las niñas; así como un menor reconocimiento y financiamiento para los deportes de niñas y mujeres. Tal

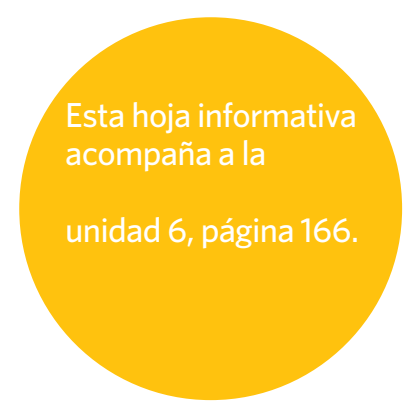


discriminación es una violación a los derechos de las niñas. Afortunadamente, la labor de advocacy comunitaria y los cambios en las leyes están comenzando a abordar estas desigualdades a nivel local, nacional e internacional; $y$ las actitudes y creencias sesgadas están empezando a cambiar.

\section{¿Qué tipos de actividad física pueden tener efectos nega- tivos en la salud?}

El trabajo que incluye largas horas de actividad agotadora, como cargar objetos pesados o los movimientos repetitivos, como agacharse, pueden ser dañinos. Las condiciones inseguras pueden también hacer que la actividad física relacionada con el trabajo sea más peligrosa; por ejemplo, trabajar en donde se tiene que aspirar sustancias tóxicas o si se trabaja bajo un calor extremo. Muchos deportes, especialmente los de contacto, también conllevan riesgo de lesiones.

\section{abuso de substancias}

\section{¿Qué drogas usan las personas y por qué las usan?}

Además de los medicamentos, las drogas que las personas usan para recreación incluyen el alcohol, el tabaco, la cafeína, la mariguana, los inhalantes (como la gasolina, el pegamento y los líquidos para limpieza), la cocaína y la heroína. Las drogas afectan la mente y el cuerpo, a veces de manera permanente.

Algunas drogas son más peligrosas que otras y sus efectos difieren para cada persona. El alcohol y el tabaco son las drogas más comúnmente utilizadas a nivel mundial. En años recientes, el uso del tabaco por niñas y mujeres ha aumentado dramáticamente en algunos países. Las personas usan drogas recreativas para muchos propósitos, que incluyen:

- reducir la ansiedad en situaciones sociales;

- parecer una persona madura y con confianza en sí misma;

- evitar sentir o tratar con los problemas, incluidos el aburrimiento y la soledad;

- adaptarse socialmente o divertirse;

- estimular sus mentes y permanecer despiertas;

- aumentar las percepciones sensoriales o sentirse "elevado";

- reducir el apetito o evitar comer (para perder peso);

- relajarse o dormir; y

- para sobrellevar un trauma.

\section{¿Qué es una adicción?}

Cuando las personas usan una droga con regularidad, se pueden volver dependientes o adictas a ella. Muchas drogas pueden ser adictivas, incluidos algunos medicamentos como los analgésicos, los complementos dietéticos, o las ayudas para dormir; y las personas pueden volverse adictas sin reconocer que lo son. Muchas personas encuentran muy difícil o imposible dejar de usar una droga una vez que han adquirido la adicción. Superar una adicción requiere determinación, fuerza de voluntad, confianza en uno mismo y un ambiente favorable, lo que con frecuencia incluye un tratamiento profesional o que la persona se involucre en un programa de tratamiento.

\section{¿Qué problemas graves pueden resultar del uso o abuso de} las drogas?

El abuso de substancias por las y los adolescentes es un importante problema de salud pública en muchos países. El uso de drogas puede llevar a problemas graves, que incluyen:

- accidentes cuando se maneja un vehículo bajo la influencia del alcohol u otras drogas;

- comportamiento del cual la persona se lamenta posteriormente por no haber estado en su pleno juicio y por tener sus inhibiciones disminuidas debido al uso de drogas;

- tener relaciones sexuales sin protección contra las ITS, VIH o embarazo, como resultado del juicio disminuido;

- contraer VIH o hepatitis al compartir agujas al inyectarse drogas; $y$

- sobredosis de una droga hasta el punto de envenenamiento y muerte.

Las personas que viven con la adicción pueden también recurrir a medidas desesperadas, degradantes o ilegales con el fin de conseguir el dinero para comprar drogas. Las personas que fuman cigarrillos, mastican tabaco, o que pasan mucho tiempo cerca de quienes fuman, pueden desarrollar cáncer u otras enfermedades que ponen en riesgo sus vidas. El uso de algunas drogas, tanto legales como ilegales, por parte de una mujer embarazada puede dañar al feto. 


\section{¿Qué sucede durante el parto?}

Cuando una mujer está a punto de dar a luz, su cuerpo entra en una etapa llamada "trabajo de parto". El trabajo de parto comienza con una o más de las siguientes condiciones: mucosidad clara o de color rosado que fluye de la vagina; líquido amniótico que fluye de la vagina; y contracciones del útero que se perciben como un endurecimiento del vientre.

La intensidad de las contracciones aumenta durante el trabajo de parto. El cuello uterino se abre y las contracciones uterinas empujan al bebe a través del cuello uterino abierto y la vagina. El trabajo de parto generalmente dura de 5 a 18 horas, pero varía para cada mujer. Usualmente es doloroso (aunque la percepción de dolor varía en las mujeres y puede depender de la preparación que ellas tuvieron durante la atención prenatal), es agotador y puede provocar ansiedad. Sin embargo, para muchas mujeres el trabajo de parto y el nacimiento constituyen una experiencia maravillosa e increíble.

\section{¿Qué es una sección cesárea?}

Una sección cesárea, también conocida como sección C, es un método quirúrgico para el parto. Durante este procedimiento, se hace una incisión a través del abdomen y útero de la mujer por donde se saca el bebé. Esto se hace usualmente cuando un parto vaginal pondría en riesgo la vida o la salud de la madre o el bebé. Sin embargo, algunas veces este procedimiento se aplica para beneficio del médico más que de la mujer o el bebé; por ejemplo, para permitir que el médico programe un momento conveniente para el parto. Las secciones cesáreas innecesarias pueden aumentar los riesgos para la salud de la madre y el bebé, incluido el riesgo de muerte.

\section{¿Qué tipo de ayuda necesitan las mujeres al dar a luz?}

Cada vez que una mujer da a luz — ya sea en su hogar, en un puesto de salud o en un hospital - ella necesita atención de una persona capacitada como una partera o médico. También, son necesarios un conjunto de condiciones apropiadas y el acceso a servicios de atención especializada en caso de emergencia. Las condiciones y prácticas relacionadas con el parto varían alrededor del mundo. En algunos países, todas las mujeres tienen acceso a la atención especializada; pero, en otras partes, la mayoría de las mujeres dan a luz en su hogar sin el apoyo de un asistente capacitado y careciendo de las condiciones apropiadas o atención de emergencia de respaldo. En algunos lugares, las mujeres en trabajo de parto también dependen del apoyo de otras mujeres. En otros lugares, los esposos o parejas de las mujeres están presentes y pueden apoyarlas. Algunas mujeres dan a luz solas, sin apoyo alguno.

\section{¿Cuáles son las consecuencias de que las mujeres den a \\ luz sin atención especializada?}

Dado que las complicaciones ocurren en alrededor del 15 por ciento de todos los partos, la carencia de asistentes capacitados y de acceso a la atención de emergencia resulta en enfermedades y muertes que podrían evitarse. Cada año, más de medio millón de mujeres mueren y entre 8 y 15 millones de mujeres sufren graves lesiones o discapacidades, como la fístula obstétrica, debido a causas relacionadas con el embarazo y parto. Casi todas esas muertes ocurren en los países en desarrollo. Casi todas esas muertes podrían evitarse a través de la atención especializada durante el parto y la atención obstétrica de emergencia oportuna de las complicaciones; la planificación familiar para reducir los embarazos no planeados; y el acceso a los servicios de aborto seguro.

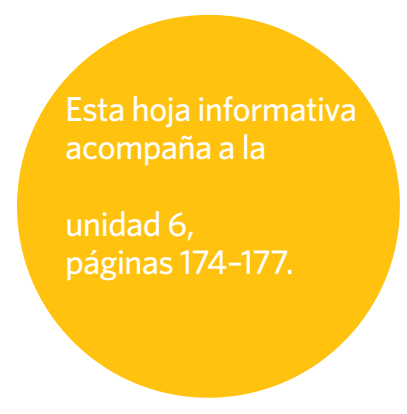




\section{¿Qué son las fístulas obstétricas y cómo afectan a las mujeres?}

Una fístula obstétrica es una abertura entre la vagina y la vejiga o el recto, algunas veces en ambos lugares, que permite que la orina y/o heces se escapen de forma continua. Cuando una mujer experimenta un bloqueo del trabajo de parto y no tiene acceso a una sección cesárea, la presión prolongada de la cabeza del bebé sobre el tejido que separa la vejiga y la vagina o el recto, puede causar una abertura llamada fístula.

En la mayoría de los casos, el bebé muere debido al trabajo de parto prolongado. Para la mujer, el olor de la filtración de orina o heces, o de ambas es constante y humillante; muchas mujeres con esta condición son abandonadas por sus esposos; y su familia, amistades y comunidades las evitan o rehúyen de ellas. A falta de tratamiento, la fístula puede conducir a problemas médicos crónicos, incluidas las ulceraciones, enfermedad renal y daños en los nervios de las piernas.

Cada año ocurren cerca de 100,000 casos de fístula obstétrica, en su mayoría en África Subsahariana y Asia. Las fístulas ocurren de manera desproporcionada en niñas y mujeres empobrecidas, especialmente en aquellas que tienen pelvis pequeñas, porque su crecimiento no está completo todavía o se ha atrofiado debido a la desnutrición. Usualmente, las fístulas pueden ser reparadas quirúrgicamente en un hospital. Sin embargo, se estima que unos dos millones de mujeres viven con fístula sin tratamiento.

\section{¿Por qué es importante el amamantamiento?}

La leche materna es el único alimento perfecto para un bebé, especialmente para el recién nacido. La primera leche de color amarillento, llamada calostro, es rica en nutrientes y anticuerpos para proteger al bebé de enfermedades e infecciones. También ayuda a limpiar el intestino del bebé. El amamantamiento durante la primera hora después del nacimiento ayuda a que el útero deje de sangrar y que la leche empiece a fluir. Adicionalmente, la leche materna siempre está limpia, lista y a la temperatura correcta. Ayuda a la madre y el bebé a sentirse cerca y es gratuita. (La Organización Mundial de la Salud recomienda el amamantamiento exclusivo durante los primeros 6 meses de la vida del bebé. De ser posible, es conveniente extender el amamantamiento después de los seis meses en combinación con alimentos seguros y nutritivos).

\section{¿Qué puede hacer una mujer que sea VIH-positiva y esté embarazada para reducir la probabilidad de transmitir el} virus a su bebé?

Una mujer embarazada y VIH-positiva puede transmitir el virus a su bebé durante el embarazo, el trabajo de parto, el parto y a través del amamantamiento. Si la mujer no toma medicamentos preventivos y amamanta, hay alrededor de un 20-45 por ciento de probabilidad de transmitir la infección a su bebé. En la actualidad, sin embargo, hay medicamentos efectivos que pueden prevenir la transmisión del VIH de una madre a su bebé durante y después del embarazo. Una mujer VIH-positiva que esté o desee estar embarazada necesita del asesoramiento de un médico acerca de cuáles medicamentos debe tomar y cuándo hacerlo. Las madres VIH-positivas deben también hablar con las personas que les proporcionan servicios de salud respecto a las opciones apropiadas para la alimentación de sus hijos recién nacidos, con el objeto de reducir la probabilidad de transmisión a través de la leche materna. En zonas en donde una madre puede no tener acceso con regularidad a agua potable y leche de fórmula, es mejor amamantar exclusivamente durante los primeros 6 meses y destetar abruptamente después. Combinar el amamantamiento con leche de fórmula o comida para bebés conlleva el mayor riesgo de pasar el VIH de la madre al hijo. Al tomar medicamentos preventivos y seguir las pautas apropiadas de alimentación, una madre VIH-positiva puede reducir la probabilidad de transmitir el VIH a su bebé. 


\section{pubertad y niñas}

Para las niñas, la pubertad comienza entre los 8 y 13 años de edad, cerca de dos años antes que los niños. Típicamente, las niñas terminan la pubertad entre los 16 y los 17 años, o alrededor del momento en el que su crecimiento esquelético se ha completado.

\section{¿Qué cambios experimentan las niñas durante la}

\section{pubertad?}

Los cambios ocurren de manera diferente para cada persona. Aunque puede haber variaciones en los tiempos, secuencia y rapidez, los cuerpos de las niñas típicamente se desarrollan en este orden:

- Comienza el crecimiento de las mamas, frecuentemente primero en un lado. El desarrollo completo toma alrededor de dos años.

- El vello púbico comienza a crecer, aumentando gradualmente y se vuelve más grueso y rizado.

- Dentro del cuerpo de la niña, la superficie de la vagina engrosa y el útero y ovarios aumentan de tamaño. [Ver hoja informativa sobre los Sistemas Sexual y Reproductivo Femenino.]

- La menarquia, o primer sangrado menstrual, usualmente ocurre de dos a tres años después de que comienza el desarrollo de las mamas. Muchas niñas tienen períodos irregulares durante los primeros dos años. Una vez que la niña ovula, ella puede embarazarse. [Ver hoja informativa sobre el Ciclo Menstrual.]

- El pelo en la axila crece y el sudor cambia, resultando en un olor corporal adulto.

- El cuello uterino comienza a producir mucosa que es expulsada por la vagina. Esta mucosa es normal y es un signo de cambios naturales relacionados con la fecundidad y la menstruación.
Las niñas también experimentan una racha de crecimiento, su pelvis y caderas se amplían. El tejido adiposo aumenta y la piel se vuelve más grasosa, lo que aumenta la probabilidad de padecer acné.

Al igual que en los niños, los intereses y sentimientos de las niñas pueden también cambiar con la pubertad. En los días previos a la menstruación, es común que las niñas experimenten fuertes emociones de diferentes clases; por ejemplo, alegría, tristeza, sensibilidad y enojo.

\section{Manejo de la menstruación}

La menstruación es algo natural y es parte de ser una mujer saludable. El tener la primera menstruación puede ser un evento emocionante, especialmente si la niña sabe qué esperar. Desafortunadamente, muchas niñas se preocupan cuando llega la menstruación porque nadie les ha explicado lo que significa o requiere. Algunos padres pueden sentirse avergonzados para abordar el tema. $\mathrm{O}$, las niñas pueden haber asimilado mensajes de su cultura o religión que sugieren que la menstruación es algo sucio. Pero la menstruación es parte de la forma en que el cuerpo se renueva a sí mismo y sirve para mantener la fecundidad.

En general, durante su menstruación, una adolescente puede hacer todas sus actividades habituales. Bañarse durante la menstruación es importante. Debe lavarse la vulva con agua y jabón neutro, para remover cualquier residuo de sangre.

La forma en que las mujeres se ocupan de su menstruación varía en los diferentes entornos. Muchas mujeres usan almohadillas sanitarias (toallas sanitarias, compresas) para absorber la sangre. En algunos lugares, las mujeres compran almohadillas que pueden desecharse después de usarlas.

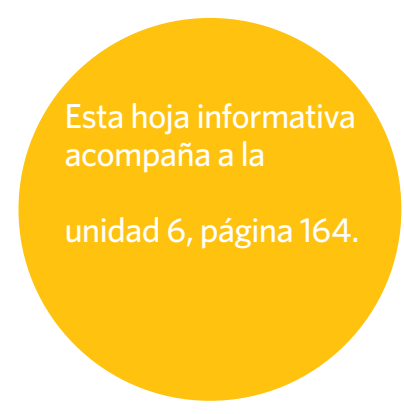


En otros lugares, emplean almohadillas reutilizables hechas con tela doblada; estas almohadillas deben lavarse bien con agua y jabón después de cada uso. Es importante tener acceso a un lugar privado para cambiarse o lavar las almohadillas (tanto en el hogar como en la escuela).

Muchas mujeres y niñas usan tampones en lugar de-O además de-las almohadillas o toallas. Un tampón es una masa de algodón (u otro material absorbente); y con frecuencia tiene forma de un dedo para que se le pueda introducir cómodamente en el canal vaginal. Estos se insertan en la vagina para que absorban el flujo menstrual. Deben lavarse las manos antes y después de colocarse el tampón. Los tampones tienen que cambiarse al menos dos veces al día. Dejar el tampón dentro de la vagina por más de un día puede causar una seria infección, que puede ser incluso mortal. (Insertar un objeto sucio dentro de la vagina también puede causar una grave infección).

La cantidad de sangrado menstrual - el flujo menstrual varía de un día a otro y de persona a persona. El sangrado puede ser más intenso durante los primeros días del período. Algunas mujeres también experimentan dolor-cólicos abdominales - durante esos días. En algunos casos, esos cólicos son fuertes y están acompañados por náusea. Un medicamento suave para el dolor como el ibuprofeno, puede ayudar. También puede ayudar, tomar un baño o colocar una botella de plástico o bolsa de agua caliente llena de agua tibia en la parte baja del vientre o de la espalda.

Unos días antes de que comience su período menstrual, algunas mujeres pueden experimentar uno o más tipos de molestias. Éstas incluyen irritación de las mamas, estreñimiento, cansancio, granos cutáneos y emociones intensas que son más difíciles de controlar que de costumbre. Otros meses ellas pueden experimentar algunas, otras o ninguna de estas molestias. Muchas mujeres encuentran que su malestar premenstrual y sus cólicos menstruales tienden a disminuir si realizan ejercicio con regularidad durante el mes.

Es común que las niñas tengan preguntas o problemas con la menstruación En este caso, pueden encontrar útil hablar con una trabajadora de la salud, alguna familiar o amiga.

[También ver la hoja informativa sobre el Ciclo Menstrual y la hoja informativa sobre Sistemas Sexual y Reproductivo Femenino.] 


\section{pubertad y niños}

Para los niños, la pubertad comienza usualmente entre los 10 y los 13 años de edad, un par de años después que las niñas. Los hombres generalmente terminan su pubertad alrededor de los 20 años,, cuando su crecimiento esquelético está completo.

\section{¿Qué cambios experimentan los hombres adolescentes \\ durante la pubertad?}

Al igual que las mujeres, los hombres jóvenes pueden darse cuenta que sus sentimientos e intereses cambian durante la pubertad. Por otro lado, también ocurren cambios físicos. Estos cambios son diferentes en cada persona pero generalmente ocurren en este orden:

- Los testículos y el pene crecen.

- El vello púbico comienza a crecer. Aumenta gradualmente y se vuelve más grueso y rizado.

- La voz comienza a cambiar y hacerse más profunda, usualmente de manera gradual pero a veces repentinamente.

- Después de cerca de un año de que empiezan a crecer los testículos, el adolescente puede comenzar a experimentar eyaculaciones (liberación de un fluido blanco lechoso llamado semen).

- El pelo en la axila crece y el sudor cambia, resultando en un olor corporal adulto.

- La barba crece.

Los jóvenes también experimentan un crecimiento rápido o estirón y aumento de musculatura. La piel se vuelve más grasosa, lo que aumenta la probabilidad de padecer una condición de la piel llamada acné. Cerca de la mitad de los niños experimentan un ligero crecimiento de las mamas, el cual desaparece en uno o dos años.

\section{¿Qué causa las erecciones?}

Las erecciones ocurren a lo largo de la vida. Una erección es causada por el llenado con sangre del tejido esponjoso del pene como resultado de la estimulación sexual; por levantar peso o hacer un esfuerzo; al soñar; por el frío; por usar ropa apretada; por miedo o excitación; o por tener la vejiga llena al despertar. Una erección puede no tener causa aparente, especialmente durante la pubertad. Los jóvenes con frecuen- cia tienen erecciones repentinas o espontáneas, en ocasiones muchas veces al día. Esto es el resultado de niveles altos o cambiantes de la hormona testosterona.

Tener una erección sin eyaculación puede causar una sensación temporal de "pesadez", pero no es dañina de modo alguno. Si un pene erecto no se toca, la erección desaparecerá por sí sola.

\section{¿Qué sucede durante la eyaculación?}

Antes de la eyaculación, las glándulas de Cowper liberan una o dos gotas de fluido a través de la punta del pene. Esto se llama pre-eyaculación y limpia la uretra. La pre-eyaculación por sí sola no contiene un número suficiente de espermatozoides que tengan la capacidad para causar el embarazo (a menos que todavía esté presente el esperma de una eyaculación reciente). Sin embargo, el VIH sí puede estar presente en la pre-eyaculación.

Una eyaculación completa implica la liberación del semen, el cual contiene cientos de millones de espermatozoides en una cantidad equivalente a una cucharadita de fluido. Casi siempre, la eyaculación viene con una oleada de liberación de tensión placentera conocida como orgasmo. Una vez que un adolescente puede eyacular, él puede causar un embarazo.

\section{¿Qué son los sueños húmedos?}

Los hombres tienen erecciones con regularidad durante el sueño y cerca del 80 por ciento de los hombres eyaculan de manera ocasional. Este tipo de eyaculación se llama emisión nocturna o "sueño húmedo". Los sueños húmedos son muy comunes durante la pubertad, pero los hombres adultos pueden también tenerlos. Un hombre o adolescente que se masturba o que tiene relaciones sexuales con regularidad, tiene menos probabilidad de tener sueños húmedos.

Los sueños húmedos (y la masturbación) no son dañinos de forma alguna. Pueden liberar la tensión y ser una fuente de placer. Tampoco los sueños húmedos (o la masturbación) "desperdician" el esperma. Los testículos están produciendo nuevo esperma continuamente; y los sueños húmedos son una forma en la que el cuerpo se deshace del esperma almacenado. [Ver también la hoja informativa sobre Sistemas Sexual y Reproductivo - Masculino.

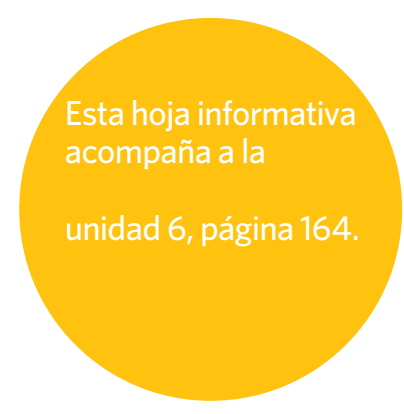




\section{¿Cómo ocurre el embarazo?}

Antes de que pueda ocurrir un embarazo, un óvulo y un espermatozoide tienen que unirse. Esto se llama fecundación. La fecundación puede ocurrir solamente durante la fase fecunda del ciclo menstrual de la mujer. [Ver hoja informativa sobre el Ciclo Menstrual.]

Durante la fase fecunda de la mujer, uno de sus dos ovarios libera un óvulo. A este evento se le llama ovulación. En el lapso de unos minutos, unas proyecciones con forma de dedos (llamadas fimbrias tubáricas) en los extremos del tubo falopiano comienzan a moverse para envolver al óvulo y atraerlo dentro del tubo. También durante la fase fecunda, el cuello uterino de la mujer se mueve a una posición que facilita que el esperma entre desde la vagina. El cuello uterino segrega una gran cantidad de moco cervical claro. Este moco proporciona alimento para permitir que el esperma sobreviva por varios días. El moco también proporciona un ambiente que ayuda al esperma a que se desplace hacia arriba rumbo a la trompa de falopio, para llegar al óvulo.

Durante la relación sexual, el esperma es eyaculado cerca del cuello uterino. Los espermatozoides entran al cuello uterino en cuestión de segundos. Si la mujer es fecunda, parte del esperma puede llegar al óvulo en la trompa de falopio en un lapso de cinco minutos, mientras que otra parte del esperma puede sobrevivir en la mucosidad clara (y "fecunda") del cuello uterino. De esta forma, por hasta cinco días después de la eyaculación, el esperma continúa saliendo del cuello uterino y está disponible para fecundar un óvulo. Por consiguiente, es probable que una mujer que ovule varios días después de que tuvo una relación sexual desprotegida, tenga esperma remanente en el cuello uterino; y ese esperma puede todavía ser capaz de llegar a la trompa de falopio y fecundar un óvulo.
No obstante, una vez que ocurre la ovulación, la fecundación tiene que ocurrir dentro de las siguientes 24 horas porque ese tiempo es lo que el óvulo puede sobrevivir. La fecundación tiene lugar en el tubo falopiano. Una vez que un espermatozoide se ha fundido con el óvulo, crea una barrera para otros espermatozoides. El óvulo fecundado continúa entonces su recorrido hacia abajo rumbo al útero, impulsado por contracciones tubáricas y por los cilios (pequeñas proyecciones parecidas a cabellos dentro del tubo).

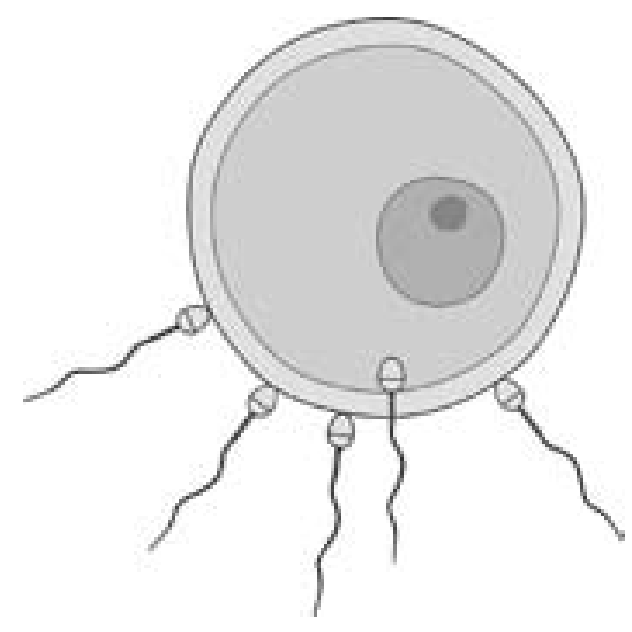

\section{¿Qué sucede después de la fecundación?}

En la trompa de falopio, el óvulo fecundado, o cigoto, comienza a dividirse y crecer, conforme se mueve hacia el útero. Este viaje toma alrededor de cinco días. Después de que se ha dividido una vez, se le llama embrión. En el transcurso de dos días de haber llegado al útero, el embrión se adhiere o implanta en el recubrimiento del útero. La implantación es el comienzo del embarazo. 


\section{¿Cómo puede una mujer saber si está embarazada?}

Los signos tempranos del embarazo difieren en cada mujer y entre diferentes embarazos. Éstos incluyen:

- falta de un período menstrual;

- senos sensibles al tacto o hinchados;

- pezones sensibles;

- micción frecuente

- fatiga poco usual;

- náusea y vómito

- cólicos;

- sensación de hinchazón;

- cambios en el apetito; y

- sensación de emotividad poco usual.

El embarazo puede confirmarse con una prueba de embarazo, que puede ser practicada por un prestador de servicios de salud o adquirida en una farmacia. Algunas mujeres que han aprendido cómo detectar cuando su cuerpo está ovulando, pueden predecir con bastante exactitud qué día debe ocurrir la menstruación; por lo tanto, ellas pueden darse cuenta de un embarazo en cuanto se atrasa la menstruación.

\section{¿Qué sucede durante el embarazo?}

Después de la implantación, el embrión (llamado blastocisto en esta etapa), también da lugar a la formación de un saco amniótico y una placenta. El saco proporciona un ambiente protector en forma de fluido para el feto en crecimiento. La placenta proporciona nutrientes y oxígeno de la madre al feto; y canaliza los productos de desecho. Un cordón umbilical conecta la placenta con el feto.

El embarazo dura 38 semanas después de la fecundación (alrededor de 40 semanas desde el último período menstrual). El embarazo se divide en tres períodos de cerca de tres meses cada uno.
Durante el primer trimestre, hasta la semana 12, se forman todos los principales órganos y estructuras corporales: el cerebro, corazón, pulmones, ojos, oídos, brazos y piernas. Después de la octava semana, al embrión se le llama feto. Es común que las mujeres sientan náuseas durante el primer trimestre; algunas veces a estas náuseas se le llama "enfermedad de la mañana”.

Durante el segundo trimestre, desde la $13^{\mathrm{a}}$ hasta aproximadamente la $27^{\mathrm{a}} \mathrm{o} 28^{\mathrm{a}}$ semana, el feto crece rápidamente; y, usualmente, alrededor de la 19a semana, la mujer puede sentir el movimiento fetal. La mayoría de las mujeres comienzan a subir de peso en el segundo trimestre.

En el tercer trimestre, el feto continúa subiendo de peso y sus movimientos se vuelven más fuertes y frecuentes.

\section{¿Qué pueden hacer las mujeres para promover un}

\section{embarazo saludable?}

Si una mujer o niña decide continuar con su embarazo, es particularmente importante para ella el evitar medicaciones innecesarias, drogas y alcohol. Es muy importante tomar los suplementos vitamínicos y minerales recomendados (especialmente hierro y ácido fólico, incluso antes del embarazo, si es posible). Ella debe también visitar a una o un prestador de servicios prenatales, de quien pueda obtener chequeos médicos y aprender acerca del embarazo, signos de peligro potencial y parto. Las mujeres que viven con el VIH deben tomar medicamentos anti-VIH para evitar que el feto se infecte y para mantener su propia salud. El tratamiento con medicamentos anti-VIH durante el trabajo de parto y el parto es muy importante para reducir el riesgo de transmitir el VIH al bebé. 


\section{selección de sexo}

\section{¿Qué es la selección de sexo?}

La selección de sexo es la práctica de hacer pruebas para determinar el sexo de un feto durante el embarazo y elegir si conservarlo o abortar el embarazo con base en el resultado de las pruebas.

\section{¿Por qué la gente practica la selección de sexo?}

La principal razón por la que las personas practican la selección de sexo es porque viven en una sociedad en la que los hijos varones son valorados por encima de las hijas. En algunos entornos, los hijos continúan el linaje y nombre de la familia, heredan las propiedades de la familia, proveen ingreso familiar, apoyan a los padres en su vejez y realizar los ritos funerarios de los padres. Por otra parte, en esas sociedades se espera que las hijas abandonen a la familia en la que nacieron para vivir con la familia del esposo. Las políticas gubernamentales que restringen el número de hijos que una mujer puede tener, contribuyen aún más a la decisión de abortar los fetos femeninos.

En las sociedades en donde los niños son preferidos, muchas mujeres están bajo extrema presión para tener hijos varones. Dar a luz a un hijo varón aumenta la condición de la mujer. El no poder producir un heredero masculino puede resultar en que una mujer sufra de culpa, abuso o, incluso, de abandono. En algunas situaciones, una mujer puede ser coaccionada a hacerse una prueba para determinar el sexo de su feto y abortar si el feto es femenino.

\section{¿Cómo se realiza la selección de sexo?}

Una variedad de procedimientos - originalmente diseñados para ayudar a monitorear el embarazo — permiten a los prestadores de servicios de salud la identificación del sexo de un feto. En algunos entornos, estos procedimientos son ampliamente utilizados específicamente para identificar el sexo fetal, con la intención de abortar si el feto es femenino.
Previo al embarazo: En algunos casos, los especialistas en fecundidad pueden posibilitar que los padres seleccionen el sexo de su bebé antes del embarazo. Algunas técnicas especiales se utilizan para separar el esperma masculino y femenino dentro de una muestra de semen. (El sexo de un bebé se determina por el esperma del padre, no por el óvulo de la madre.) Solamente el esperma que es del sexo deseado se usa - ya sea mediante inseminación artificial de la mujer o a través de la fecundación in vitro.

Durante el embarazo: Existen varios procedimientos para identificar el sexo fetal durante el embarazo. Uno de estos procedimientos es el ultrasonido, el cual usa ondas sonoras para generar una imagen aproximada del feto en una computadora. Otro procedimiento es la amniocentesis (insertar una aguja en el fluido amniótico que rodea al feto, para extraer y analizar el fluido). Un tercer procedimiento se llama muestreo de chorionic villa (remover y analizar una muestra de tejido placentario).

Después del embarazo: Algunas parejas toman medidas drásticas aún después del parto. Una niña puede ser dada en adopción, abandonada, o - en casos extremos — asesinada, simplemente por ser mujer.

\section{¿Cuáles son las consecuencias de la selección de sexo?}

La selección de sexo es resultado de la discriminación de género (y la perpetúa). En lugares en donde es un procedimiento común, como en partes de China e India, ha resultado en un número significativamente mayor de niños comparado con el de niñas. Aún donde la selección de sexo está prohibida, continúa siendo practicada. Esto sigue siendo una seria preocupación para muchos activistas por los derechos de las mujeres y para los gobiernos. 


\section{¿Qué son los sistemas sexual y reproductivo?}

Los sistemas sexual y reproductivo comparten algunos órganos, pero no todos. El sistema sexual consiste de aquellos órganos involucrados en la actividad y placer sexual, mientras que el sistema reproductivo en las mujeres consiste en aquellos órganos involucrados en el embarazo y parto.

\section{¿Cuáles son las partes de los sistemas sexual y reproductivo femenino y sus funciones?}

La vulva consiste de todos los órganos genitales externos visibles de la mujer (ver la siguiente ilustración).

El clítoris (\#1 en la ilustración) es un pequeño órgano, con forma parecida al capullo de una flor con un poco de tejido formando un pequeña "capuchón”. El único propósito del clítoris es dar placer sexual a las niñas y mujeres; y contiene

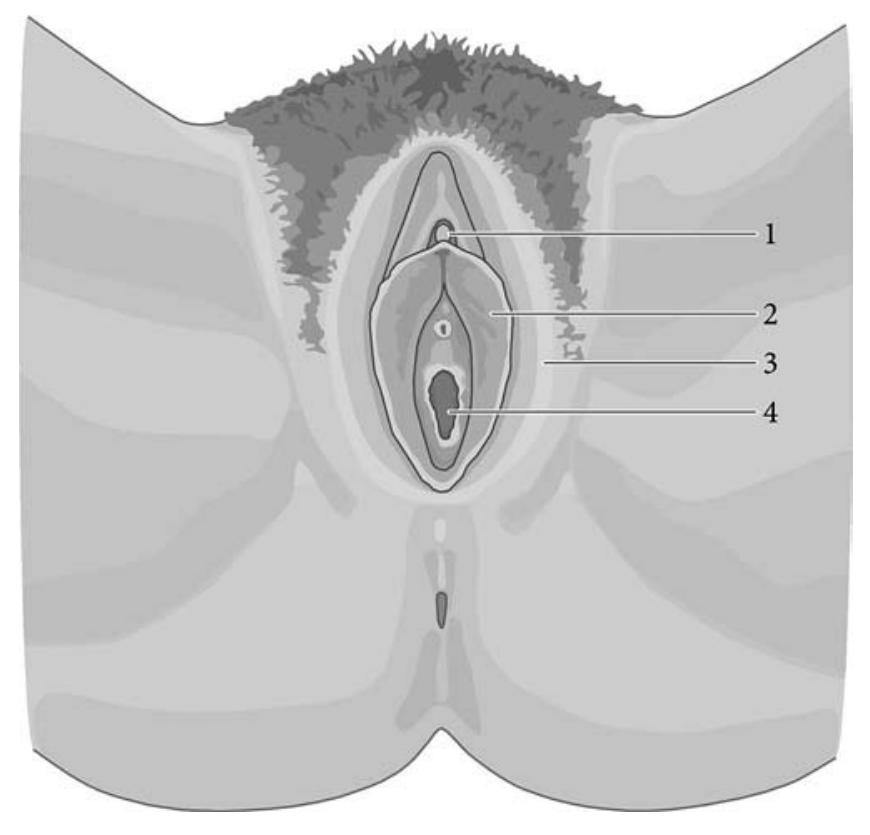

una abundante red de terminaciones nerviosas para captar la sensación. Durante la excitación sexual y el orgasmo, el clítoris (y en general los genitales) se congestiona y llena de sangre, lo que causa que este órgano se ponga erecto. Las mujeres pueden sentir contracciones vaginales durante el orgasmo.

Los labios mayores o labios externos (\#3) cubren y protegen el orificio vaginal. Los labios menores o labios internos (\#2) también se hinchan durante la excitación sexual.

La vagina (\#4) es un canal elástico, que conduce desde la vulva hasta el cuello uterino y el útero. Cuando una mujer está excitada sexualmente, la vagina se lubrica. Sin embargo, no tiene muchas terminaciones nerviosas y, por lo tanto, no es muy sensible. Durante la relación sexual vaginal, el pene se introduce en la vagina. Si el hombre eyacula, el semen entra en la vagina y viaja a través del cuello uterino dentro del útero y las trompas de falopio, en donde puede ocurrir la fecundación si hay un óvulo presente. La sangre menstrual sale del cuerpo a través de la vagina, al igual que lo hace el bebé cuando nace. La vagina se limpia a sí misma y no necesita ser lavada. Tampoco deben las mujeres insertar substancias para secar o estrechar la vagina, pues pueden ser peligrosas.

El himen (no mostrado en la ilustración anterior) es una membrana delgada que puede extenderse a través de parte del orificio vaginal. El himen puede rasgarse fácilmente durante la práctica de deportes u otra actividad física; y puede también estirarse hasta abrirse si una niña usa tampones. La condición del himen no indica si una mujer ha tenido relaciones sexuales o no.

El cuello uterino (\#5) es la parte baja del útero, la cual se extiende dentro de la parte superior de la vagina. Un orificio en el cuello uterino llamado os, conecta a la vagina con el útero. La sangre menstrual pasa del útero a través del os; y el semen pasa a través de él al útero. El cuello uterino produce una secreción (moco cervical) que ayuda a que el esperma entre en el útero. La mucosidad cervical cambia durante el ciclo menstrual; las mujeres pueden aprender a identificar el período fecundo con

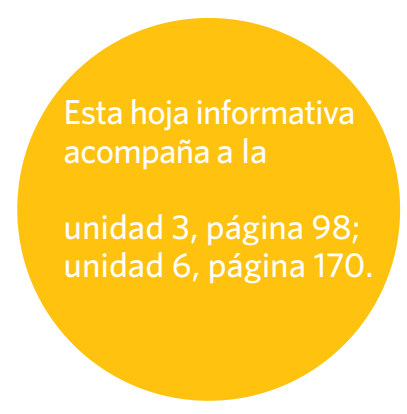




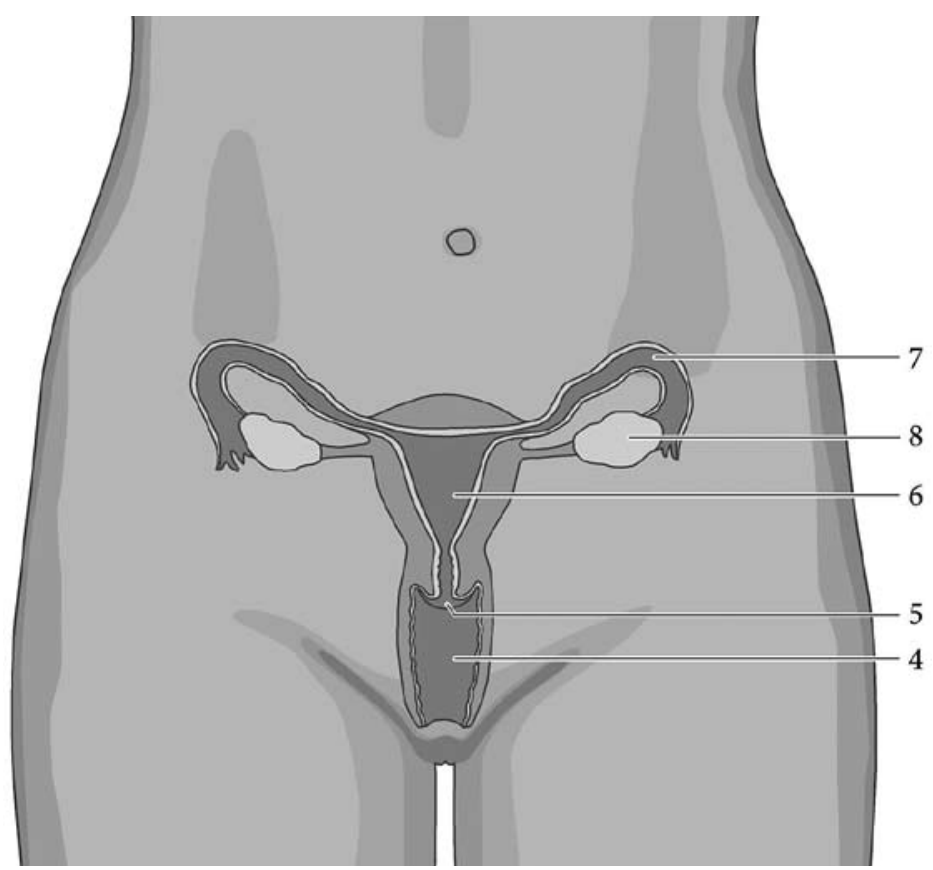

base en las características de esa mucosidad. Durante el parto, el cuello uterino se estira, permitiendo que el bebé pase a través de él.

El útero (\#6) es un órgano muscular hueco que descansa sobre la vejiga. Tiene una forma parecida a una pera invertida. Tiene un recubrimiento (llamado endometrio), que se engrosa con sangre y tejido durante la primera parte de la ovulación-ciclo menstrual. Si ningún embrión se implanta, el recubrimiento se rompe, convirtiéndose en el flujo menstrual. Si un embrión se implanta, un feto se desarrolla en el útero.

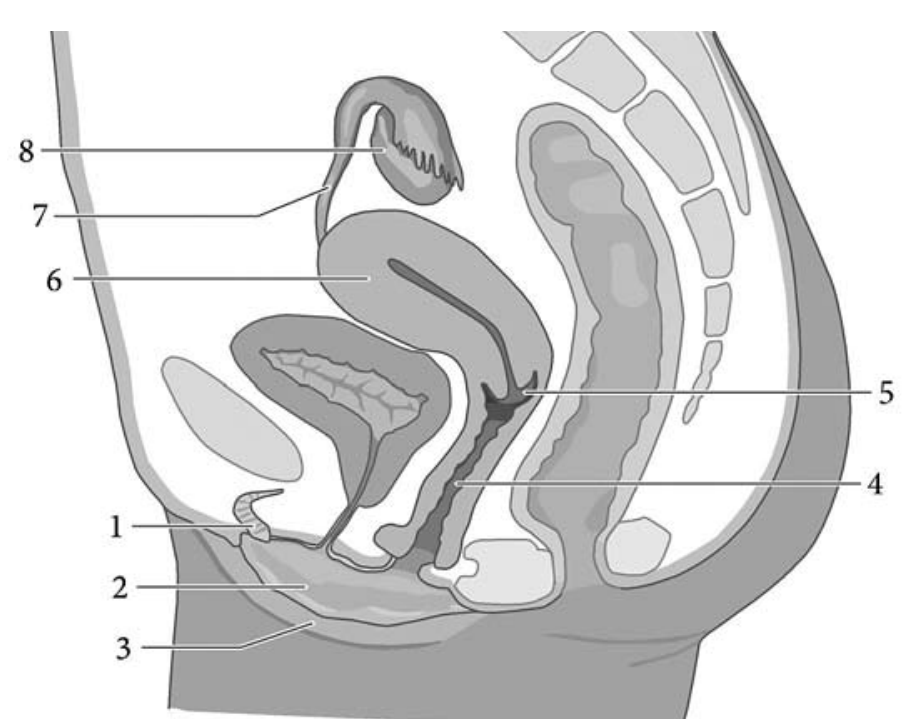

Las Trompas de Falopio (\#7) son dos tubos muy delgados de entre 10 y 13 centímetros de largo, a través de los cuales el óvulo viaja desde el ovario hasta el útero; y en donde el óvulo puede ser fecundado.

Los ovarios (\#8) son dos órganos del tamaño de una almendra o una uva, que almacenan los óvulos inmaduros en folículos, producen y segregan hormonas femeninas (estrógenos y progesterona); y producen y liberan óvulos maduros. 


\section{sistemas sexual y reproductivo - masculino}

\section{¿Qué son los sistemas sexual y reproductivo?}

Los sistemas sexual y reproductivo comparten algunos

órganos, pero no todos. El sistema sexual consiste de aquellos órganos involucrados en la actividad y placer sexual. En los

hombres, el sistema reproductivo incluye aquellos órganos involucrados en la producción, almacenamiento o transporte del esperma para la reproducción.

\section{¿Cuáles son las partes de los sistemas sexual y reproductivo masculino y sus funciones?}

El pene (\#1) tiene varias funciones. Está involucrado en la sensación sexual; en esta función, corresponde al clítoris de las mujeres. El pene puede llenarse de sangre y ponerse duro y erecto en respuesta a la estimulación sexual. La función reproductiva del pene es depositar semen dentro de la vagina. La tercera función es la excreción de orina (ver uretra más adelante). La punta del pene está dentro de una capa de piel llamada prepucio. En muchas poblaciones, el prepucio se remueve a través de un procedimiento denominado circuncisión.

Los testículos (o testes) (\#2), son dos glándulas con forma de pelota que se alojan dentro del escroto, producen esperma y la hormona masculina testosterona. El escroto y los testículos son sensibles al tacto y pueden ser una fuente de placer.

El escroto (\#3), una bolsa holgada de piel, contiene y protege a los testículos. Cuando hace frio, se retrae hacia el cuerpo para mantener los testículos a la temperatura correcta para producir esperma.

La uretra (\#4) es un tubo que se extiende desde la vejiga a través del pene. La uretra es el pasaje a través del cual el semen (una mezcla de fluido seminal, fluido prostático y esperma) viaja hacia fuera del cuerpo durante la eyaculación; la orina también sale del cuerpo a través de la uretra. Una válvula situada en la parte inferior de la vejiga se cierra cuando el pene está erecto, para evitar la micción durante la eyaculación.

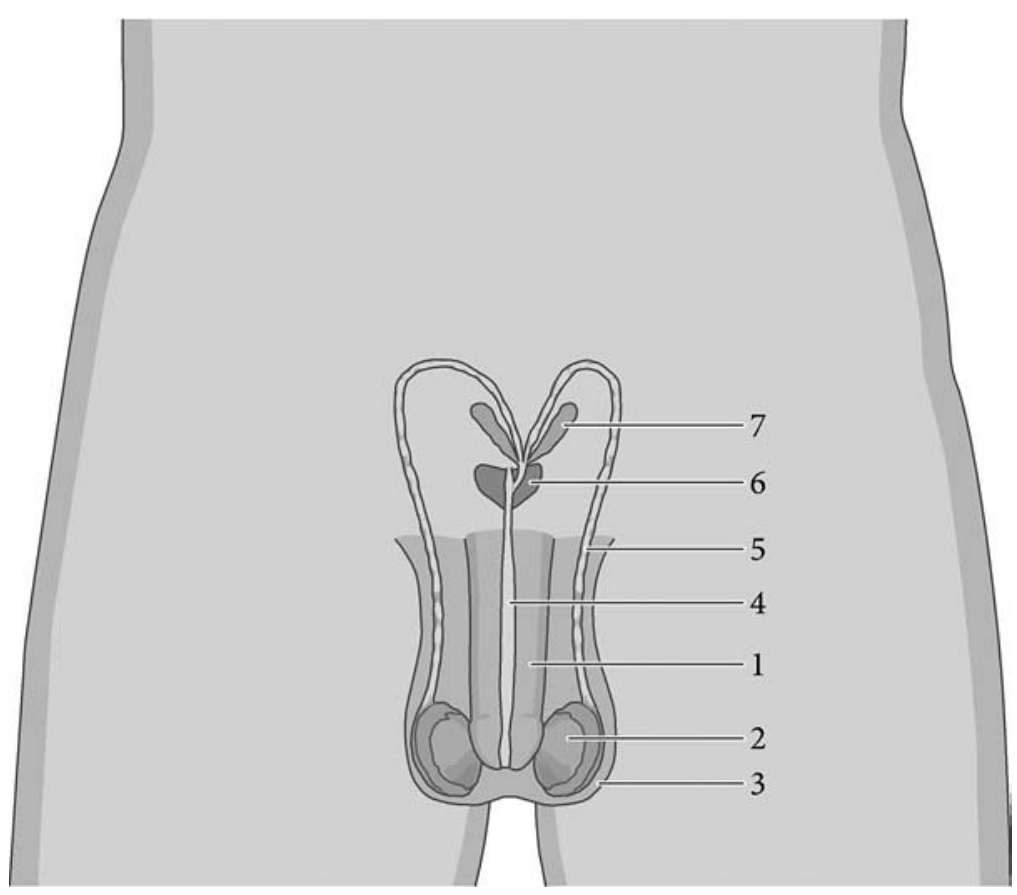

El epidídimo (no numerado pero visible en la ilustración anterior) es un tubo enrollado en forma de ovillo que se sitúa encima de cada testículo y almacena el esperma conforme madura, hasta que es eyaculado.

Los vasos deferentes (\#5) son dos tubos delgados que transportan el esperma hacia la uretra. Se contraen durante la eyaculación.

La glándula prostática (\#6) produce un fluido que constituye parte del semen y ayuda a que los espermatozoides se muevan. Muchos hombres encuentran sexualmente placentero cuando se estimula la próstata.

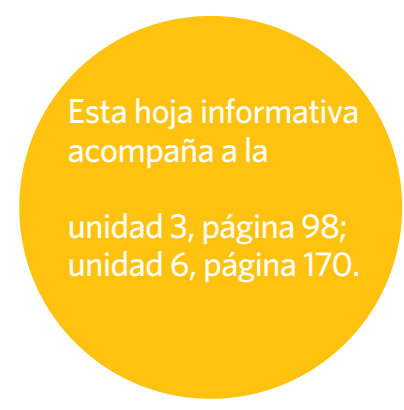


Las vesículas seminales (\#7) producen gran parte del fluido que finalmente se convierte en semen. Este fluido alimenta a los espermatozoides.

Las glándulas de Cowper (no mostradas) producen un fluido alcalino espeso, llamado pre-eyaculación, que neutraliza el ácido presente en la uretra antes de la eyaculación.

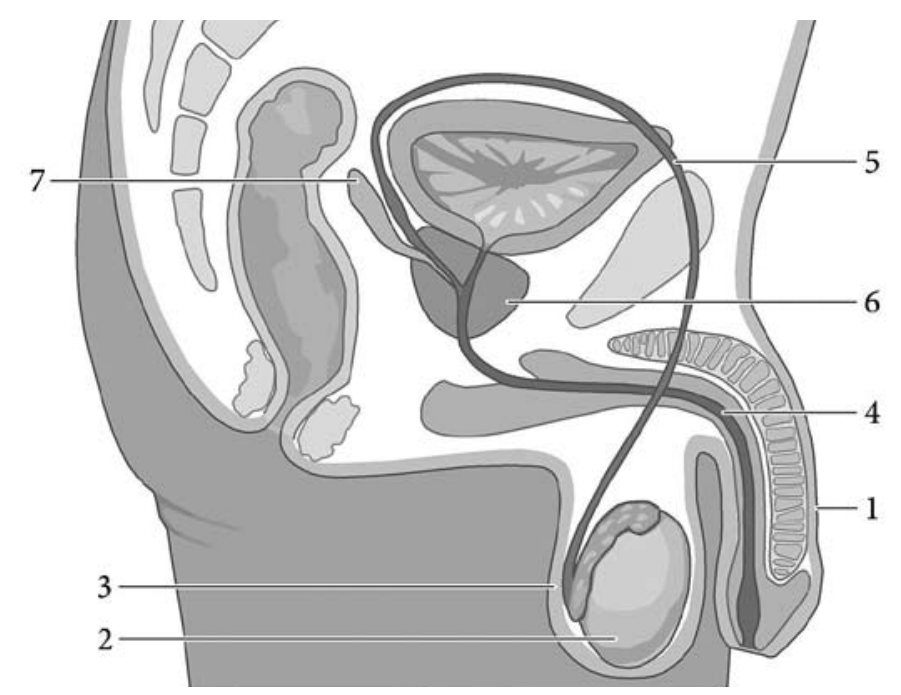




\section{trata de seres humanos con fines de explotación sexual}

\section{¿Qué es la trata de seres humanos con fines de explotación sexual?}

La trata de seres humanos con fines de explotación sexual consiste en el reclutamiento, transporte, venta o compra de seres humanos con el propósito de explotarles sexualmente a través de la prostitución, pornografía, exhibición de desnudos, espectáculos de sexo en vivo, turismo sexual o matrimonio forzoso. La mayoría de las víctimas de la trata de seres humanos con fines de explotación sexual son niñas y mujeres jóvenes. Las tácticas coercitivas, incluidos el engaño, fraude, intimidación, aislamiento, amenaza y uso de la fuerza física, así como la servidumbre por deuda (ser forzado a pagar deudas con trabajo directo en vez de dinero o en especie), son usadas para atraer y controlar a las víctimas. Algunas niñas y mujeres son vendidas en el comercio sexual por sus propios padres, esposos o parejas sentimentales.

\section{¿Qué tan extendida está la trata de seres humanos con} fines de explotación sexual?

La exacta dimensión de la trata de seres humanos con fines de explotación sexual es desconocida, debido a que la trata es ilegal, generalmente realizada en forma clandestina $y$, por o tanto, difícil de rastrear. Además, diferentes definiciones de la trata de seres humanos con fines de explotación sexual complican los esfuerzos para establecer el número de personas afectadas en el mundo. Sin embargo, esta es una industria global en rápido crecimiento, de la cual hay reportes de cada región del mundo. Esta actividad genera enormes ganancias y tiene vínculos con el crimen organizado.

\section{¿Cuáles son las consecuencias de la trata de seres}

\section{humanos con fines sexuales?}

Con frecuencia y de manera cotidiana, las victimas tienen que soportar un trato y condiciones degradantes y brutales, lo que incluye la inanición, el confinamiento, los golpes, la violación (incluida la violación en grupo), el uso forzado de drogas, esterilización y abortos forzados, amenazas de violencia contra ellas mismas y sus familias, así como amenazas de exponer sus actividades a su familia y amigos. Las consecuencias para la salud incluyen lesiones físicas (por ejemplo, huesos rotos, conmoción, quemadas y rasgado vaginal y anal); adición a las drogas y el alcohol; infecciones de transmisión sexual, incluida la infección con VIH; aborto espontáneo; e infecundidad. El trauma físico y emocional llevado al extremo puede resultar en reacciones psicológicas agudas, como la separación de mente y cuerpo, trastorno por estrés post traumático y pensamientos suicidas. Las víctimas están en riesgo de muerte prematura por homicidio, suicidio, abuso de drogas y alcohol y por VIH.

\section{¿Qué puede hacerse para prevenir la trata de seres} humanos con fines de explotación sexual?

La respuesta a la trata de seres humanos con fines de explotación sexual requiere de medidas para prevenirla, encargarse de los autores del delito de trata y dar atención adecuada a las víctimas.

Las medidas preventivas incluyen:

- empoderar a las mujeres;

- proporcionar oportunidades educativas, vocacionales y de empleo a mujeres y niñas;

- emprender campañas educativas, dirigidas a víctimas potenciales;

- capacitar a maestros, trabajadores juveniles y otras personas para identificar a las niñas en alto riesgo de ser vendidas; y trabajar con sus familias y comunidades para evitarlo; y

- aprobar leyes y conducir actividades educativas para reducir las causas que impulsan la trata; $y$

- establecer programas preventivos de colaboración entre los países emisores, receptores y de tránsito.

Las medidas para encargarse de los autores del delito de trata incluyen:

- fortalecer las leyes y sanciones, y su aplicación;

- establecer divisiones de policía dedicadas a encontrar y arrestar a los autores de este delito; y

- desarrollar mecanismos integrales de protección a testigos.

Los servicios para las víctimas deben abordar sus necesidades inmediatas: protección, atención médica, reparación legal de daños, vivienda, empleo y consejería. Las víctimas de la trata de seres humanos no deben ser castigadas, penalizadas o arrestadas. Deben ser apoyadas incondicionalmente, sin importar su condición legal o documentación. Los gobiernos deben dar prioridad y asignar recursos suficientes para combatir la trata de seres humanos con fines de explotación sexual; y, en el largo plazo, abordar sus causas de raíz, especialmente la pobreza, así como la desigualdad y la discriminación de género.

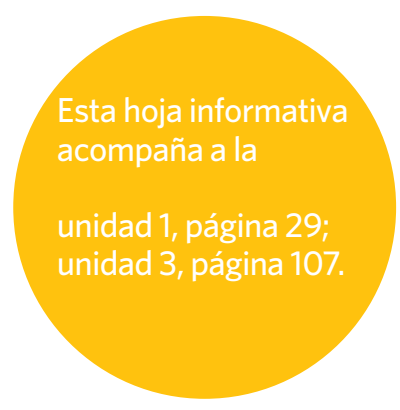


Ver también la hoja informativa sobre Infecciones de Transmisión Sexual.

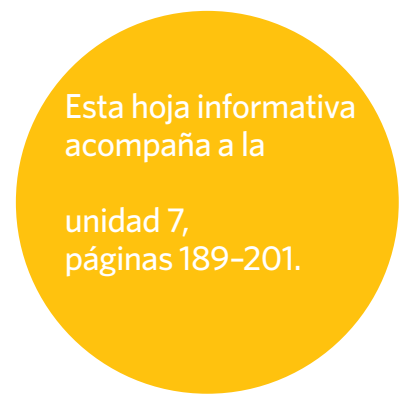

\section{VIH (virus de la inmunodeficiencia humana) y SIDA (síndrome de inmunodeficiencia adquirida)}

\section{¿Cuál es la diferencia entre el VIH y el SIDA?}

El VIH (virus de la inmunodeficiencia humana) es un virus que ataca y deteriora el sistema inmune de una persona. Cuando el sistema inmune se debilita debido al VIH, el cuerpo ya no puede luchar contra las enfermedades y puede desarrollar infecciones y cánceres graves que, con frecuencia, son un riesgo para la vida. Esta condición es conocida como SIDA (síndrome de inmunodeficiencia adquirida). Las personas que viven con el VIH pueden también ser diagnosticadas con SIDA si sus pruebas de sangre muestran que el número de células del sistema inmune que combaten las enfermedades han disminuido por debajo de cierto nivel.

\section{¿Cómo se transmite el VIH?}

El VIH está presente en los fluidos corporales de las personas que han sido infectadas con el virus. Una persona que es VIH-positiva puede transmitir el virus a otras personas a través de su semen (incluida la pre eyaculación), secreciones vaginales, leche materna o sangre. El virus es transmitido más comúnmente a través del intercambio de semen y secreciones vaginales durante la relación sexual. El VIH no solamente se transmite a través de las relaciones sexuales vaginales entre un hombre y una mujer; puede también ser transmitida a través de las relaciones sexuales anales entre dos hombres. Tener una infección de transmisión sexual puede aumentar el riesgo de adquirir o transmitir el VIH durante la relación sexual. El VIH puede también ser transmitido a otras personas por medio de la transfusión de sangre infectada, por compartir agujas para el uso de drogas o esteroides con una persona que vive con la infección o por someterse a la perforación corporal o tatuajes. El VIH también puede transmitirse de una madre VIH-positiva a su bebé durante el embarazo, parto o el amamantamiento. Las relaciones sexuales orales también conllevan algún riesgo de transmisión del VIH.

Si bien el uso de instrumentos contaminados durante el arreglo de las manos, de los pies, o al rasurarse, puede conllevar un riesgo de infección, la transmisión del VIH a través de estas rutas es altamente improbable. El VIH no puede transmitirse al tocar, besar, estornudar, toser, por compartir comida, bebidas o utensilios, o a través del contacto cotidiano en el trabajo, escuela o el hogar; tampoco a través del uso de piscinas, baños públicos, o por piquetes de insectos. El VIH no puede transmitirse a través de la saliva, lágrimas o sudor. La orina y las heces no transmiten el VIH si no contienen sangre

\section{¿Cómo se puede prevenir el VIH?}

Actualmente no hay una vacuna o cura para el VIH, por lo que la prevención es esencial.

La transmisión sexual puede prevenirse mediante la abstención de relaciones sexuales desprotegidas, o mediante el uso de condones masculinos o femeninos cada vez que se tiene una relación sexual. Otro enfoque para la prevención es limitarse a una sola pareja sexual; esto es, ser mutuamente "fieles" o monógamos. Sin embargo, este enfoque funciona solamente si ambas partes de la pareja son realmente monógamas y si realmente son VIH-negativas. Desafortunadamente, muchas personas no están conscientes de si ellas — o sus parejas ya están infectadas con el VIH; la única forma de saber con seguridad es hacerse la prueba del VIH. Además, nadie puede garantizar que su pareja nunca tendrá otra pareja sexual. Por estas razones, el enfoque de "ser fiel" conlleva riesgos para algunas personas. Para los hombres, la circuncisión ofrece alguna protección contra el VIH, pero no elimina el riesgo de la infección. Para las mujeres, no hay beneficios directos conocidos de la circuncisión masculina. Por lo tanto, aún los hombres circuncidados deben usar condones.

La transmisión por agujas por compartir una aguja infectada puede también evitarse usando solamente agujas nuevas o estériles para todas las inyecciones o perforaciones de la piel.

Transmisión madre a hijo — Las mujeres embarazadas deben siempre hacerse la prueba del VIH. Las mujeres embarazadas VIH-positivas pueden tomar medicamentos preventivos para reducir las probabilidades de que su bebé sea infectado por el VIH durante el embarazo y parto. La transmisión del virus de la madre al bebé puede también ocurrir después del parto a través del amamantamiento. Las madres VIH-positivas deben buscar el asesoramiento de algún prestador de servicios de salud para prevenir la transmisión del VIH durante el embarazo y parto, así como para aprender las opciones apropiadas de alimentación para sus hijos recién nacidos. [Ver hoja informativa sobre Parto y Amamantamiento.] 


\section{¿Puede ser curada o tratada la infección con VIH?}

La infección con VIH no puede curarse, pero puede sujetarse a tratamiento. Actualmente, el tratamiento para el VIH se llama terapia antirretroviral (TAR). La TAR es una combinación de medicamentos que reduce el nivel del VIH en la sangre y hace más lenta la destrucción del sistema inmune. La TAR ha mejorado la calidad y duración de la vida de muchas personas con VIH. La TAR también reduce la enfermedad y muerte debida al SIDA, la etapa más avanzada de la infección con VIH. No todas las personas responden de igual manera a los medicamentos. Sin embargo, sin tratamiento, una persona infectada con VIH generalmente desarrolla el SIDA en algún momento dentro de uno a diez años después de ser infectada. Una persona con SIDA sin tratamiento puede vivir menos de un año.

\section{¿Cómo puede una persona saber si él o ella - o su pareja - tiene VIH?}

La única forma de saber si usted ha sido infectado con el VIH es hacerse una prueba del VIH. La única forma de saber si su pareja sexual es VIH-positiva, es que él o ella se haga una prueba de VIH y comparta el resultado con usted. Millones de personas que son VIH-positivas se sienten y parecen completamente sanas, no tienen síntomas y no tienen idea de que están transmitiendo el virus a otras personas.

La prueba del VIH detecta la presencia de células especiales (llamadas anticuerpos VIH) si la persona está infectada. Usualmente, las pruebas pueden detectar los anticuerpos contra el VIH dentro de seis a ocho semanas posteriores a la exposición. En raros casos puede tomar hasta seis meses para que el nivel de anticuerpos sea detectado por una prueba de laboratorio.

Un resultado positivo de la prueba del VIH significa que la persona tiene anticuerpos contra el VIH y que está infectada con el virus. Si la primera prueba es positiva, una segunda prueba diferente se realiza para confirmar los resultados. Una prueba del VIH negativa significa que la persona no está infectada con el VIH.

O puede significar que la persona está infectada pero todavía no ha producido suficientes anticuerpos contra el VIH para resultar positiva en la prueba. Alguien que resulte VIH-negativo pero que sospeche que ella o él estuvo expuesto recientemente al virus, debe hacerse de nuevo la prueba en unos cuantos meses.
¿Por qué las personas deben hacerse la prueba del VIH?

Hay muchas razones por las que es importante hacerse la prueba del VIH. El obtener un resultado negativo puede traer un enorme alivio a la persona. También puede alentarla a practicar un comportamiento sexual más seguro en el futuro. Para quienes resultan VIH-positivos, a partir del resultado pueden empezar a buscar atención y tratamiento. El tratamiento puede mejorar la calidad y prolongar significativamente la vida de una persona que es VIH-positiva. Las personas que se hacen la prueba pueden también informar y proteger a sus parejas sexuales. Es muy importante para una mujer que esté - o que desee estar - embarazada, saber su condición de VIH, de tal forma que pueda tomar medidas para reducir el riesgo de transmisión a su bebé. [Ver hoja informativa sobre Parto y Amamantamiento.]

\section{¿Qué tipo de apoyo necesitan las personas que viven con el VIH y SIDA?}

Cuando las personas se enteran de que son VIH-positivas, pueden sentir temor, confusión y depresión. Estar infectadas con VIH es una condición que cambia sus vidas y se necesita tiempo para ajustarse al hecho de saberlo. Las personas que viven con el VIH necesitan un sólido sistema de soporte emocional, el cual puede incluir a los padres, cónyuges o parejas, otros miembros de la familia, amistades, personal de consejería, trabajadores sociales, otras personas que viven con el VIH y SIDA, o líderes religiosos o espirituales.

Estas personas necesitan encontrar a una o un médico que sea comprensivo, respetuoso y que conozca sobre el VIH y el SIDA; y tener acceso a tratamiento médico cuando lo necesiten. También, necesitan aprender tanto como sea posible sobre el VIH y SIDA, y cómo proteger su propia salud y la de sus parejas sexuales. Para permanecer tan saludables como sea posible, necesitan comer bien; ejercitarse con regularidad; tener un descanso adecuado; y evitar fumar, tomar demasiado alcohol y el uso de drogas recreativas. Y, lo más importante, al practicar siempre el sexo seguro, ellas pueden protegerse a sí mismas de otras infecciones de transmisión sexual, así como evitar infectar a otras personas con el VIH. 


\section{violencia contra mujeres y niñas, incluida la violencia sexual}

\section{¿Qué tan extendida está la violencia contra las mujeres y niñas?}

Tristemente, la violencia contra las mujeres y niñas (algunas veces llamada violencia basada en género) está muy extendida. Es un serio problema de salud pública y de derechos humanos. A nivel mundial, las tasas de ese tipo de abuso varían ampliamente. En la mayoría de los entornos, sin embargo, entre un tercio y dos tercios de las mujeres son golpeadas, obligadas a tener actividad sexual, o pueden también ser víctimas de abuso por parte de una pareja íntima a lo largo de su vida. Cientos de miles de mujeres y niñas cruzan anualmente fronteras siendo víctimas de trata de seres humanos. Aproximadamente 140 millones de mujeres y niñas han sido sometidas a mutilación genital femenina y otros 3 millones están en riesgo de sufrirla cada año en África. En la próxima década, más de 100 millones de niñas en los países en desarrollo contraerán matrimonio siendo niñas. En cada zona de guerra, la violencia contra las mujeres, incluida la violación sistemática, ha sido denunciada durante o después de los conflictos armados.

\section{¿Cuáles son las consecuencias de tal violencia?}

Las consecuencias para la salud incluyen:

- dolor y lesiones graves, como huesos rotos, quemaduras, ojos morados, cortadas, moretones, dolor (de cabeza, de abdomen de músculos), que en ocasiones tienen que soportar por años; - problemas de salud mental como la depresión, ansiedad y trastornos de la alimentación;

- disfunción sexual, incluidas las relaciones sexuales con dolor, falta de deseo y temor a las relaciones sexuales; y

- problemas de salud reproductiva, incluido el aborto espontáneo, infección por ITS o VIH, embarazo no planeado y una mayor toma de riesgos sexuales entre adolescentes.

Las lesiones graves, el homicidio intencional y el suicidio relacionados con la violencia, contribuyen en conjunto a las tasas de mortalidad femenina. En una comunidad, la violencia puede perpetuar la falsa creencia de que los hombres son mejores que las mujeres. La violencia basada en género crea un clima de temor e inseguridad en las familias, escuelas, comunidades y centros de trabajo.

\section{¿Cuáles son algunas estrategias efectivas para combatir la violencia contra las mujeres?}

Cambiar actitudes y conducir otros esfuerzos de prevención, al:

- involucrar a los hombres en cambiar las actitudes culturales sobre masculinidad y comportamiento violento;

- integrar el tema de género, incluyendo información sobre la violencia basada en género, a la educación formal e informal;

- introducir campañas, como los 16 Días (anuales) de Activismo para Terminar con la Violencia contra las Mujeres

- educar a las mujeres y niñas sobre sus derechos legales;

- realizar actividades para empoderar a las mujeres y las niñas; y

- terminar con el matrimonio infantil, que coloca a muchas niñas en relaciones en las que están en riesgo de violencia.

Proporcionar servicios: Las mujeres que han experimentado violencia y sus hijos pueden necesitar acceso a varios servicios (idealmente en un mismo sitio). Ellas pueden necesitar teléfonos de emergencia, consejería, redes de apoyo, refugios seguros, servicios legales y atención a la salud, incluida la anticoncepción de emergencia para las víctimas de violación.

Proporcionar capacitación: El personal de servicios de salud puede ayudar en la detección de casos de abuso y en el apoyo a víctimas, al ofrecer servicios de apoyo médico, psicológico y legal, así como al enviar a sus clientes referidos a otros servicios.

Cambiar leyes, lo que incluye:

- demostración de compromiso político a través de declaraciones hechas por funcionarios gubernamentales de alto nivel y apoyadas por acciones y el compromiso de recursos;

- promulgación e implementación de leyes que aborden la

violencia contra las mujeres; evaluar la aplicación de esas leyes

- desarrollo de pautas y protocolos, así como la provisión de capa-

citación obligatoria y sistemática para la policía, fiscales y jueces;

- establecimiento de tribunales y unidades de policía

especializados en el tema; y

- promulgación de políticas enérgicas de arresto y proceso judicial, y sentencias apropiadas;

Expandir el conocimiento: La investigación y documentación sobre la violencia contra las mujeres y niñas aumenta el reconocimiento del problema y el compromiso para abordarlo. 

